UNIVERSIDADE DE SÃO PAULO

FACULDADE DE EDUCAÇÃO, INSTITUTO DE FÍSICA, INSTITUTO DE QUÍMICA, INSTITUTO DE BIOCIÊNCIAS

\title{
Padrões morais, valores e conceitos empregados por alunos de ensino fundamental em discussões sociocientíficas
}

\author{
BRUNO CINE RIBEIRO DO CARMO
}

Orientadora: Professora Doutora Sílvia Luzia

Frateschi Trivelato

\begin{abstract}
Dissertação de mestrado apresentada ao Instituto de Física, ao Instituto de Química, ao Instituto de Biociências e à Faculdade de Educação da Universidade de São Paulo, para a obtenção do título de Mestre em Ensino de Ciências.
\end{abstract}

São Paulo 
Autorizo a reprodução e divulgação total ou parcial deste trabalho, por qualquer meio convencional ou eletrônico, para fins de estudo e pesquisa, desde que citada a fonte.

FICHA CATALOGRÁFICA

Preparada pelo Serviço de Biblioteca e Informação do Instituto de Física da Universidade de São Paulo

Carmo, Bruno Cine Ribeiro do

Padrões morais, valores e conceitos empregados por alunos de ensino fundamental em discussões sociocientíficas - São Paulo, 2010

Dissertação (Mestrado) - Universidade de São Paulo. Faculdade de Educação, Instituto de Física. Instituto de Química e Instituto de Biociências

Orientador: Profa. Dra. Sílvia Luzia Frateschi Trivelato

Área de Concentração: Ensino de Biologia

Unitermos: 1. Biologia - Estudo e Ensino; 2. Biologia Argumentação; 3. Ensino Fundamental; 4. Aborto;

5. Valores Morais.

USP/IF/SBI-040/2010 


\section{AGRADECIMENTOS}

À Sílvia, pela orientação sempre humana, maternal e rígida, na medida certa. Também pelo exemplo de pessoa competente, elegante e fofa. E pelos risotos maravilhosos, claro!

Aos colegas de GEPEB, Rafa, Rena, Sandra, Érica, Paula, Dani, Sarah, Paty, Maíra, Rodrigo, Zé, Celi, Sansão e Roger, seja pela amizade, pela presença inspiradora, pelo companheirismo, pelas dicas, pelas caronas, pelas "pérolas" e pelas tardes de sexta-feira divertidas, calorosas e inteligentes.

Ao Zé e à Martha pelas orientações da qualificação, pela leitura cuidadosa e pela atenção amiga que recebi.

Ao Gilberto, por não permitir que a casa se torne solitária e por me conceder a melhor relação amigo-irmão que eu já tive.

Ao Gilmar também, por sua presença canina, suas artes destrutivas e sua fiel prontidão, a todo momento, para um abraço e uma lambida.

Ao meu pai, à minha mãe e ao meu irmão, pela minha infância, pelas brincadeiras e pelos valores que eu recebi ou que fomos construindo juntos.

A tantos outros amigos que, sem saber, contribuíram, direta ou indiretamente com a conclusão deste trabalho, seja através de uma semente de idéia ou da energia que vem da amizade: Mariella, Leo Â., Eduardo, Laíla, Júlia, Paty, Leo T., Jean, Lê, Alê, Luís e muitos outros queridos.

Ao Jorge, que me orientou sobre a possibilidade de mudar de área no mestrado, e assim entrar neste programa que estou concluindo.

À divindade, nas diversas formas em que eu já acreditei, e principalmente nas formas em que eu acredito hoje, ao acaso, à sorte, ao Universo e à Terra pela minha vida e pelas generosas fontes de conhecimento que se têm mostrado disponíveis a mim.

A todos os que já foram meus professores e meus alunos. Também a todos que ainda serão. 


\section{Resumo}

CARMO, B. C. R. Padrões morais, valores e conceitos empregados por alunos de ensino fundamental em discussões sociocientíficas, Dissertação de Mestrado, Faculdade de Educação, Instituto de Biologia, Instituto de Física, Instituto de Química, Universidade de São Paulo, 2010.

Questões sociocientíficas são dilemas sociais de natureza polêmica que envolvem moralidade e ética. O problema da validade ética do aborto possui ligações conceituais com a Ciência e é uma questão bastante controversa, representando uma questão sociocientífica. Neste trabalho, foram transcritos e analisados trechos da interação de adolescentes discutindo a questão do aborto. A unidade de análise foi o argumento segundo o padrão de Toulmin (2003), a partir do qual foram identificados valores empregados pelos alunos, como: priorização de questões sociais; riscos e responsabilidade; respeito ao valor da vida; valores familiares e relacionais e regras de decisão. Os valores usados na discussão foram representativos das linguagens éticas do cuidado e da justiça, se usarmos os termos derivados da área da psicologia moral. Os mais freqüentes foram os chamados valores familiares e relacionais. Os alunos resolveram as questões utilizando raciocínios baseados em princípios, raciocínios consequencialistas, deliberações baseadas em emoção ou em intuição. As posições intuitivas foram mais comuns, seguidas pelo raciocínio baseado em princípios. Alguns conceitos científicos se mostraram presentes na discussão, indicando que temas sociocientíficos são oportunidades de integração de tais conteúdos. Os conceitos presentes foram: método contraceptivo, interdependência funcional, tecnologia médica, desenvolvimento, funcionamento da pílula do dia seguinte, óvulo, genes, sangue, DNA, maturidade sexual e gravidez. Foram analisadas também, segundo o padrão de Toulmin, as funções de conceitos e valores nos argumentos. Os conceitos apresentavam principalmente função de dados, enquanto os valores apresentavam principalmente função de garantias, conforme esperado e identificado na literatura. Outras funções para conceitos científicos e valores também surgiram nos argumentos, contrastando com o padrão comumente encontrado. A preponderância de determinados padrões morais e valores pode ter diversas explicações, que vão desde a dominância de algumas formas de pensamento na classe social da qual os alunos fazem parte até a forma como as pessoas tomam decisões morais em geral. A importância dos valores e o surgimento dos conceitos científicos na discussão sugerem que os temas sociocientíficos deveriam ter um lugar privilegiado nas aulas de ciências, assim como as questões afetivas e morais que influenciam o raciocínio informal e o desenvolvimento do caráter dos indivíduos.

Palavras-chave: questões sociocientíficas, aborto, argumentação, valores, padrões morais 


\begin{abstract}
CARMO, B. C. R. Moral patterns, values and concepts used by students in socioscientific discussions, Master's Dissertation, Faculdade de Educação, Instituto de Biologia, Instituto de Física, Instituto de Química, Universidade de São Paulo, 2010.

Socioscientific issues are social dilemmas which are polemic in nature and related to morality and ethics. Abortion is such an example, as it is controversial and has conceptual links to Science. In this work, fragments from students discussions in groups about abortion were transcripted and analyzed. The Toulmin (2003) argument pattern was used as major tool for analysis, allowing the researcher to identify the values held by students, such as: social issues; risks and responsibility; respect for life; familiar and relational values and decision rules. These values can be seen as a representation of care and justice ethic languages, in terms of moral psychology. Familiar and relational values were the most frequent. Students solved the questions using consequencialist reasoning, reasoning based on principles, emotive and intuitive deliberations. Intuitive positions were more common, followed by principled reasoning. Some scientific concepts were brought up to the discussion by the students, which can be seen as an evidence of socioscientific issues working as promoters of scientific knowledge integration. The concepts found in the discussion were: contraceptive method, functional interdependence, medical technology, development, the "morning-after-pill", ovule, gens, blood, DNA, sexual maturity and pregnancy. Following the Toulmin argument pattern, the functions of values and scientific concepts were analyzed too. Concepts mainly showed up as data in the arguments, while values were seen mostly in the position of warrants, just as expected and identified in literature. They also emerged in other functions, contrasting with the most common patterns. Prevalence of some moral patterns and values could be explained in many ways, like the dominance of some thoughts and ideas in the social class to which the students belong or maybe some common mechanism of making moral choices. The importance of values and the rising of scientific concepts in the debate suggest that socioscientific themes should have a privileged place in science classes, as well as moral and affective issues which influence informal reasoning and character development.
\end{abstract}

Keywords: socioscientific issues, abortion, argumentation, values, moral patterns 


\section{SUMÁRIO}

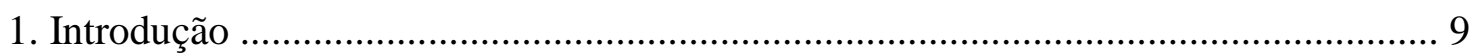

2. O Movimento CTSA e as Questões Sociocientíficas ............................................... 10

3. Moralidade nas Questões Sociocientíficas e o Aborto como Questão Sociocientífica .

4. Consideraç̃̃es acerca dos Limites da Pessoa e o Aborto ........................................... 27

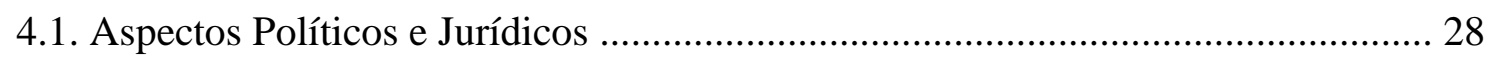

4.2. Status Moral e o Conceito de Pessoa................................................................... 30

4.3. Os Limites da Vida e a Responsabilidade da Decisão .............................................. 40

5. O Estudo da Argumentação, Questões Sociocientíficas e Valores .............................. 41

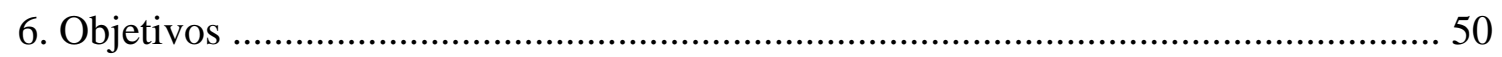

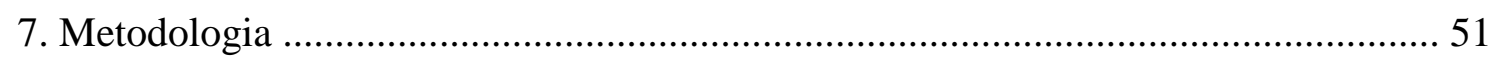

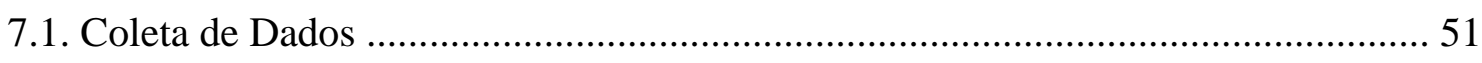

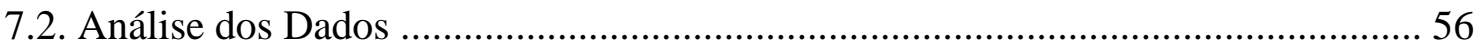

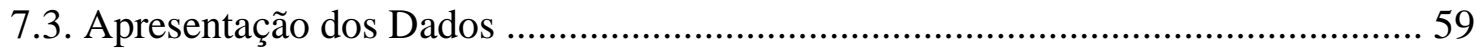

7.4. Referenciais Teóricos e Categorias de Análise ...................................................... 61

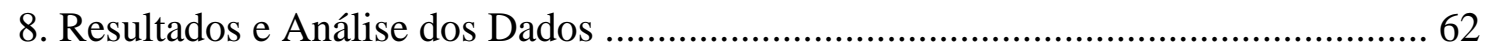

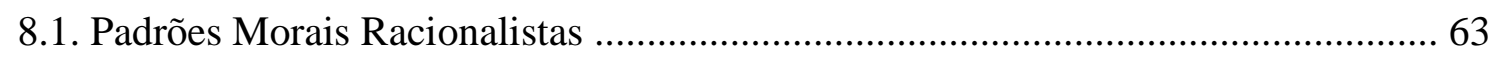

8.2. Influência do Afeto: Moral Emotiva e Moral Intuitiva ............................................ 64

8.3. Valores e Garantias: Valores de Justiça $X$ Valores de Cuidado ............................. 70

8.4. Conceitos Científicos na Discussão Sociocientífica ................................................ 87

8.5. Valores: Funções no Argumento e Relações com Padrões Morais .......................... 98

9. Conclusões e Considerações Finais …………………………………………..... 108

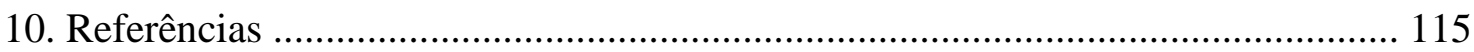




\section{Introdução}

Atualmente, para muitas pessoas em diversas sociedades, a Ciência representa o conhecimento verdadeiro sobre o mundo, possuindo um importante papel inclusive na definição de estratégias políticas de nível global, como se observa, por exemplo, nas metas estabelecidas entre diferentes países com relação a emissões de gases estufa.

Há, no entanto, certas questões envolvendo aspectos científicos que se colocam à humanidade, para as quais a Ciência não dispõe de uma solução única, definitiva e satisfatória, sobretudo quando analisadas do ponto de vista moral. Fontes de energia, utilização de células-tronco embrionárias para pesquisa, aborto, eutanásia e clonagem reprodutiva são apenas alguns exemplos. Evoluindo a partir de complexas interações entre Ciência e Sociedade, tais problemas são chamados de questões sociocientíficas. Avanços nas ciências médicas e na genética molecular associados a desafios ambientais produzidos por uma população humana crescente garantem a proeminência desse tipo de questões no presente e no futuro (SADLER, 2004; KOLSTO, 2001; ZEIDLER et al., 2002; SADLER \& ZEIDLER, 2005).

Muitas das questões controversas são oriundas do próprio avanço do conhecimento científico, já que a Ciência moderna e as sociedades das quais ela se origina compartilham uma complexa interdependência. Assim, o desenvolvimento de novas tecnologias pode gerar demandas éticas que não existiam anteriormente, como ocorre com as técnicas de clonagem e produção de transgênicos.

Simultaneamente, há um problema de democracia no acesso à tomada consciente de decisões, já que o conhecimento da população sobre os aspectos científicos e morais de tais questões não acompanha o ritmo do desenvolvimento tecnológico, do surgimento de questões controversas e da necessidade de estabelecimento de normas sociais para esses problemas. Esse quadro traz um desafio para a educação e, mais especificamente, para o ensino de ciências, já que se torna importante que os estudantes sejam educados de modo que sejam capazes de argumentar e formar opiniões baseados em diferentes aspectos dos problemas sociocientíficos considerados (PATRONIS et al., 1999).

Segundo Zeidler et al. (2005), os estudantes possuem diversos arranjos de experiências culturais que necessariamente contribuem com as formas pelas quais eles abordam e resolvem questões controversas, incluindo sociocientíficas. Visões de mundo 
e identidades que originam escolhas morais estão presentes em qualquer classe. Assim, é essencial que os educadores de ciências cultivem ambientes de aula que encorajem a expressão de diversas perspectivas, até quando tais perspectivas não são congruentes com as noções tradicionais de Ciência escolar.

O Brasil, com uma taxa de analfabetismo de 9,2 \% em 2007 (IBGE, 2008) e muitos problemas relativos à qualidade da educação, principalmente no setor público, encontra-se distante da democratização da tomada de decisões em questões sociocientíficas.

A despeito da falta de conhecimento e do baixo nível de instrução da maioria da população, as questões polêmicas envolvendo a Ciência não deixam de surgir, demandando respostas éticas. Recentemente, o Supremo Tribunal Federal trouxe à tona novamente a questão da validade ética do aborto, ao discutir sobre o status legal do aborto nos casos de anencefalia do feto.

O aborto representa uma importante questão sociocientífica em nosso país, no qual são realizados cerca de 5 milhões de abortos a cada ano, a despeito da ilegalidade de tal prática na maioria dos casos e do fato de o Brasil ser o maior país católico do mundo (LAURENTI, 1995 apud LEAL, 1998).

Considerando-se a relevância das questões e dilemas relativos ao aborto, assim como das abordagens que as pessoas utilizam para discutir o tema, este se mostra um importante nicho de investigação, não muito explorado entre as pesquisas da área de ensino de ciências. O impacto que os aspectos morais e afetivos parecem ter na tomada de decisões também surge como um assunto que demanda maior clarificação, além da função de valores e conceitos científicos no estabelecimento de conclusões para tais dilemas. Este trabalho procura analisar a discussão de temas sociocientíficos, mais especificamente o aborto, na sala de aula, através da identificação de argumentos, valores, conceitos científicos e padrões morais, bem como de suas funções e relações.

\section{O Movimento CTS e as Questões Sociocientíficas}

A partir do final dos anos 70, muitos pesquisadores da área de educação em ciências voltaram sua atenção para o desenvolvimento de um tema de estudo que refletia as influências combinadas de Ciência, Tecnologia e Sociedade (ZEIDLER et al., 2005). A nova abordagem ia ao encontro das expectativas de muitos daqueles que identificavam uma crise no ensino de ciências (MILLAR, 1996; FOUREZ, 2003), 
gerada, entre outros fatores, pela dificuldade dos professores de acompanhar as novidades tecnológicas e suas implicações e de tornar o conhecimento científico significativo para os alunos. O movimento CTS (Ciência - Tecnologia - Sociedade, e depois CTSA, em virtude da importância crescente de se considerar também os aspectos do Ambiente, cuja relação de interdependência com a tríade CTS aumenta continuamente) parecia então a solução para tornar a Ciência mais significativa para os estudantes, já que a considerava no contexto de sua interação com a Tecnologia e da influência desta na Sociedade (CONTIER, 2009). Seria como uma forma de tornar as aulas de ciências mais reflexivas e contextualizadas, em oposição a uma disciplina acadêmica isolada e irrelevante no currículo.

As razões para o interesse pelo ensino de ciências com uma abordagem CTS eram e são as mais diversas. Segundo Bennett et al. (2005), os alunos poderiam se sentir mais motivados ao perceber as relações existentes entre a Ciência e os outros aspectos da vida humana. Outros estudos indicam que os estudantes não têm noções adequadas sobre a natureza da Ciência e sobre suas relações com a Tecnologia, por exemplo. Um erro comum dos estudantes é enxergar Ciência e Tecnologia como um empreendimento comum e seus papéis como indistinguíveis (FLEMING, 1987). É também frequente que os estudantes tenham crenças diversas e contraditórias sobre o conhecimento científico, suas características e limitações (AIKENHEAD, 1987).

Outros estudos levantam ainda a questão de como os professores lidam com a ideia de Ciência e suas interfaces com outras áreas. Em um trabalho de Rubba \& Harkness (1993), a maioria dos professores amostrados (79\%) descreveriam tecnologia como "a aplicação da ciência para melhorar a vida", uma visão ingênua e limitada.

Além de atender à necessidade de uma melhor compreensão por parte de alunos e professores sobre o que a Ciência faz e quais suas relações com Tecnologia, Sociedade e Ambiente, uma abordagem CTS também estaria no mesmo sentido de uma educação mais eficiente, capaz de formar cidadãos aptos a tomar decisões e fazer escolhas conscientes.

Zoller \& Scholz (2004) identificam a ideia de CTSA (Ciência - Tecnologia Sociedade - Ambiente) como parte de um contexto no qual deve ocorrer uma mudança de paradigma de um conhecimento orientado a "LOCS - Lower-Order Cognitive Skills" para "HOCS - Higher-Order Cognitive Skills", ou seja, a abordagem CTSA integra uma necessária mudança para o desenvolvimento, nos alunos, de pensamento crítico, capacidade de tomada de decisões e resolução de problemas reais. 
Em uma visão ainda mais ampla, fornecida por Santos (2001), o ensino de ciências CTS deve incluir os seguintes itens: natureza da Ciência, História da Ciência, facetas tecnológicas, conteúdos científicos atuais e com utilidade social, espaço para diferentes fontes de informação, questões e temas de incidência social, reflexão sobre a responsabilidade social da Ciência e da Tecnologia, revalorização escolar de ideias prévias e/ou de aprendizagens vicariantes e práticas, encorajamento à ação responsável e a hábitos mentais.

Todos esses trabalhos advogam em favor da utilização de relações CTS no ensino de ciências. Em uma revisão sobre o assunto, Bennett et al. (2005) constataram que há evidências de que as atividades baseadas em contexto (CTS) motivam os alunos em aulas de ciências, geram mais atitudes positivas em relação à Ciência e também não prejudicam o entendimento que os alunos têm das ideias científicas.

Apesar de resultados empolgantes e ideologia pioneira, para alguns autores seria um erro assumir que CTS é uma abordagem única, coerente e bem-articulada para a educação em ciências. Ao invés disso, trataria-se de um movimento com várias diferentes ramificações, cada uma com história própria e com significativas tensões internas (PEDRETTI \& HODSON, 1995). Assim, segundo tal linha de pensamento, o movimento CTS acabou se tornando um tanto difuso, representando abordagens como cursos isolados focados em questões CTS particulares, estratégias pedagógicas que ressaltam as conexões entre Ciência e Sociedade, e caixas de texto em livros didáticos (PEDRETTI \& HODSON, 1995; SADLER, 2004; ZEIDLER et al., 2005). Além disso, de acordo com Zeidler et al. (2005), a abordagem CTS seria incompleta e subdesenvolvida enquanto estratégia pedagógica, em função de seu pluralismo e incoerência.

Por outro lado, o movimento relacionado às questões sociocientíficas tem surgido como uma robusta área de investigação, reunindo, aos esforços por um ensino de ciências contextualizado, considerações morais e alguns métodos de pesquisa voltados para o estudo da linguagem, como a análise de argumentos (DRIVER et al., 2000; KOLSTO, 2006). Esta abordagem tem permitido dar continuidade a uma vertente das ideias CTS de maneira coesa e produtiva.

Segundo Oulton et al. (2004), as pesquisas em questões sociocientíficas não seriam uma simples repetição da necessidade de se ensinar ciências em um contexto mais amplo, mas, além disso, uma sugestão de que alunos e professores devem entender a natureza das questões controversas, o que deveria ser um dos principais objetivos do 
ensino. Nós precisamos garantir a formação de cidadãos alfabetizados cientificamente e capazes de lidar efetivamente com as questões controversas. Como afirmado por Zeidler et al. (2002), "questões sociocientíficas" representariam um termo amplo que abrange tudo que a abordagem CTS tem a oferecer, além de também considerar a dimensão ética da Ciência, o raciocínio moral e o desenvolvimento emocional dos alunos.

Dessa forma, enquanto as vertentes CTSA tendem a focar no impacto da Ciência e da Tecnologia na Sociedade e no Ambiente, elas geralmente não exploram as implicações morais e éticas que sustentam tais questões. Em contraste, o "movimento das questões sociocientíficas" surge como uma abordagem conceitual que unifica o desenvolvimento de orientações morais e epistemológicas nos estudantes, além de considerar o papel das emoções e do caráter como componentes-chave do ensino de ciências (SADLER \& ZEIDLER, 2005). As questões sociocientíficas não serviriam apenas como um contexto para aprender Ciência, mas, além disso, como uma estratégia pedagógica com objetivos bem definidos (ZEIDLER et al., 2005).

Os pesquisadores da área definem questões sociocientíficas como dilemas sociais com ligações conceituais, procedimentais ou tecnológicas com a Ciência. (SADLER, 2004; SADLER \& ZEIDLER, 2004). Elas são de natureza tipicamente polêmica ou controversa, podem ser consideradas por uma série de perspectivas, não possuem conclusões simples e frequentemente envolvem moralidade e ética (SADLER \& ZEIDLER, 2004).

Seguindo esses parâmetros, diversos temas relacionados a saúde, biotecnologia e genética, responsabilidade ambiental e impactos de tecnologias podem ser considerados sociocientíficos. Para Sadler (2004), a sugestão de que questões relacionadas a biotecnologia e mudanças ambientais devem ser classificadas juntas como "sociocientíficas" não quer dizer que a ciência e a sociedade representam entidades independentes, mas, pelo contrário, que todos os aspectos da Ciência são inseparáveis da Sociedade da qual eles surgem.

O processo de resolução das questões sociocientíficas é melhor caracterizado como raciocínio informal, que descreve a geração e avaliação de posições em resposta a situações complexas. No raciocínio informal, diferentemente do raciocínio formal, as premissas podem mudar assim que informações adicionais se tornam disponíveis, e as conclusões não são auto-evidentes. (SADLER, 2004). Zohar \& Nemet (2002) acrescentam que o raciocínio informal envolve raciocínio sobre causas e conseqüências e sobre vantagens e desvantagens, ou prós e contras, de proposições particulares ou 
alternativas de decisão. Esta modalidade de raciocínio suporta atitudes e opiniões, trata problemas mal-estruturados que não têm solução definida, e geralmente envolve raciocínio indutivo (ao invés de dedutivo).

Questões sociocientíficas são apropriadas para currículos de diversos níveis, como ensino fundamental, médio e superior (SADLER \& ZEIDLER, 2004). Oulton et al. (2004) ressaltam que os estudantes encontrarão dilemas morais antes e depois que eles deixarem a escola. Assim, as escolas devem ajudar seus alunos a lidar com questões de valor, a aprender a fazer julgamentos por si mesmos, assim como aprender a assumir a responsabilidade por suas próprias vidas.

De acordo com Oulton et al. (2004), desenvolver um entendimento genérico da natureza da controvérsia, além da habilidade de lidar com a mesma, é mais importante do que desenvolver, nos alunos, o conhecimento de alguns assuntos em particular. Zeidler (1984) também acredita que uma parte do conteúdo tradicional deve ser sacrificada em prol de tópicos interdisciplinares sociocientíficos, e que a combinação de questões morais e éticas com o currículo de ciências não é incompatível. Essa visão pode ser associada à de outros pesquisadores em ensino de ciências, que defendem a inclusão de questões sociocientíficas nas aulas de ciências, citando seu papel central no desenvolvimento de uma cidadania responsável, capaz de aplicar conhecimento científico e hábitos de pensamento (DRIVER, NEWTON \& OSBORNE, 2000; KOLSTO, 2001; SADLER, 2004).

As diversas ramificações na área de pesquisas sobre questões sociocientíficas têm defendido o uso dos temas sociocientíficos para várias finalidades consideradas nobres no ensino de ciências, possibilitando:

- motivar e tornar a Ciência mais próxima da vida dos estudantes (CAJAS, 1999, PEDRETTI, 1999);

- melhorar as noções sobre a natureza da Ciência (BELL \& LEDERMAN, 2003; SADLER et al., 2004);

- melhorar a capacidade de argumentação (DRIVER, NEWTON \& OSBORNE, 2000; PATRONIS et al., 1999; ZOHAR \& NEMET, 2002);

- melhorar a habilidade de analisar dados científicos e informações (JIMÉNEZALEIXANDRE et al., 2000; KOLSTO, 2001; KORPAN et al., 1997);

- encorajar os estudantes a confrontar os aspectos morais da Ciência (SADLER \& ZEIDLER, 2004). 
Além disso, discussões envolvendo problemas sociocientíficos representariam um importante componente da alfabetização científica (DRIVER et al., 2000; PEDRETTI \& HODSON, 1995; PEDRETTI, 1999).

Os trabalhos na área exploram diversos aspectos relativos à aplicação dos temas sociocientíficos no ensino de ciências, como formas de lidar com as questões (GEDDIS, 1991; KORTLAND, 1996; RATCLIFFE, 1996), linguagem e qualidade de argumentação (OSBORNE et al., 2004; WALKER \& ZEIDLER, 2007), influência das noções de natureza da Ciência (BELL \& LEDERMAN, 2003; WALKER \& ZEIDLER, 2007), influência do domínio do conteúdo científico associado (RATCLIFFE, 1996), padrões de raciocínio, atitudes e valores (SOLOMON, 1992; RATCLIFFE, 1996; KOLSTO, 2006).

Sadler (2004), em uma revisão sobre raciocínio informal relativo a questões sociocientíficas, destaca que a maioria dos trabalhos na área exploram quatro temas principais:

- a avaliação da informação relativa às questões sociocientíficas;

- relações entre concepções de natureza da Ciência e tomada de decisões sociocientíficas;

- a influência do entendimento conceitual no raciocínio informal;

- argumentação sociocientífica.

Os trabalhos sobre avaliação das informações relacionadas às questões sociocientíficas relatam que os estudantes baseiam seus julgamentos em dois fatores principais: as próprias informações ou as autoridades fornecendo as informações, manifestando, então, uma postura de aceitação ou de avaliação ativa. As informações são avaliadas principalmente em função da metodologia de produção das mesmas, apesar de muitas vezes os estudantes julgarem utilizando critérios incompletos (KORPAN et al., 1997).

Kolsto (2001) destaca que as fontes de informação geralmente são julgadas pelos alunos com base em dois critérios: a confiança inspirada pela pesquisa ou a percepção de que determinada autoridade é especialista no assunto. O mesmo autor (2001) identificou quatro "estratégias de resolução" dos estudantes para decidir em que fontes de informação confiar:

- aceitação das afirmações; 
- avaliação das afirmações usando "indicadores de confiança" e "pensando por si mesmos" explicitamente;

- aceitação da autoridade dos pesquisadores ou outras fontes de informação;

- avaliação das fontes de informação em termos de "análise dos riscos",

“interesses", "neutralidade" ou "competência".

Alguns alunos usam todas essas estratégias, enquanto outros usam apenas uma ou duas. As estratégias variavam em termos de reação dos alunos, que podiam ter uma postura de aceitação ou de avaliação, assim como variavam no foco, que podia ser o conteúdo (a ser avaliado ou aceitado) ou a fonte de informação.

Ao avaliar informações, os indivíduos também são influenciados por suas percepções e uso de evidências científicas. Assim, Tytler et al. (2001) relatam o uso, por parte dos alunos, de evidência informal para estabelecer uma ligação entre informação científica e experiências pessoais. Os sujeitos da pesquisa de Bell \& Lederman (2003) consideravam a importância das evidências científicas nas suas decisões, apesar de não requererem provas absolutas. Sadler et al. (2004) notaram que os estudantes têm concepções limitadas do significado e uso dos dados, resultado corroborado pelo trabalho de Walker e Zeidler (2007), que relatam limitada referência, por parte dos estudantes, a evidências empíricas que sustentassem suas posições em um debate.

A segunda subárea apontada por Sadler (2004) trata das relações entre concepções de natureza da Ciência e raciocínio informal em questões sociocientíficas. Alguns estudos afirmam significativa relação, pois os alunos, nas discussões e entrevistas relativas aos temas polêmicos, citam a importância da evidência empírica (ZEIDLER et al., 2002) - resultado que contrasta com alguns trabalhos citados acima e demonstram consciência das influências sociais e culturais sobre a Ciência (ZEIDLER et al. 2002; SADLER et al., 2004). Trabalhos recentes também têm sugerido que o entendimento que os estudantes têm da natureza da Ciência (SADLER, CHAMBERS \& ZEIDLER, 2004; ZEIDLER et al. 2002) e a avaliação de evidência (KOLSTO, 2001; KORPAN et al., 1997; TYTLER et al., 2001) são centrais para a negociação das questões sociocientíficas.

Walker \& Zeidler (2007) sugerem o design de uma abordagem sociocientífica para explorar aspectos da natureza da Ciência, de modo que os estudantes sejam levados a desenvolver suas concepções de natureza da Ciência e, além disso, possam aplicar tais concepções em um contexto de tomada de decisões. As mesmas autoras, defendendo a 
utilização de questões sociocientíficas para melhorar as noções sobre Ciência, colocam que, à medida que os estudantes coletam, interpretam e consideram evidências de múltiplas posições defensáveis, eles podem começar a conceituar a Ciência como um empreendimento dinâmico e complexo.

Analisando as crenças sobre a natureza da Ciência, Zeidler et al. (2002) notaram diferenças entre alunos de ensino médio e alunos de ensino superior na discussão sobre o sacrifício de outras espécies em função do avanço da medicina, já que estudantes de graduação tenderam a identificar fatores sociais nas suas discussões, enquanto estudantes mais novos limitaram seu raciocínio a considerações científicas e religiosas.

Uma descoberta interessante, ainda por Zeidler et al. (2002), refere-se à compartimentalização que os estudantes fazem do conhecimento científico em relação ao conhecimento pessoal e à opinião. Apesar de alguns alunos enxergarem o conhecimento científico como sustentado por fatos, eles não considerariam utilizar evidências científicas para convencer outras pessoas a mudarem suas opiniões pessoais. É como se tais estudantes sentissem que opiniões são imunes a mudanças, não importando as evidências concretas que alguém poderia fornecer para suportar pontos de vista alternativos.

De forma similar, Sadler, Chambers \& Zeidler (2004) constataram que, para alguns alunos, o mérito científico (presença de dados e evidências) de um determinado artigo não lhe garantia maior poder de persuasão. No mesmo trabalho, quase metade dos alunos não possuíam concepções adequadas sobre "dados científicos". Alguns conseguiam reconhecer dados sem a habilidade de descrever seu uso ou significância, enquanto outros não conseguiam nem distinguir entre dados, opiniões infundadas e predições.

Na mesma área há estudos que não encontraram relação entre concepções de natureza da Ciência e raciocínio informal sobre temas sociocientíficos (SADLER, 2004). Bell \& Lederman (2003), que trabalharam com alunos de nível superior, não observaram diferenças nas decisões sociocientíficas entre grupos de pessoas que tinham visões de Ciência bem distintas. Fatores associados à natureza da Ciência tiveram um papel insignificante para uma minoria dos sujeitos e nenhum papel claro para a maioria. Nesse mesmo trabalho, quando os participantes da pesquisa discutiam a questão da implantação de tecido fetal para tratamento do mal de Parkinson, nenhuma referência direta às características do conhecimento científico foi registrada. 
Walker \& Zeidler (2007) dizem que o papel do conhecimento do conteúdo, inclusive de noções de natureza da Ciência, mostra-se secundário em relação às crenças epistemológicas que as pessoas têm sobre normas morais pessoais e sociais.

Com relação ao papel do conteúdo nas discussões de questões sociocientíficas, Sadler (2004) aponta para duas grandes tendências nos estudos. A primeira revela que a falta de entendimento conceitual dos estudantes limita o raciocínio informal (TYTLER et al., 2001; FLEMING, 1986 apud SADLER, 2004). Por outro lado, Hogan (2002), Zeidler \& Schafer (1984) e Sadler \& Zeidler (2005) fornecem evidências positivas para a relação, e mostram resultados indicando que o entendimento conceitual melhora o raciocínio informal.

Pode-se observar também uma clara divergência nos resultados de diferentes autores, pois, enquanto alguns mostram que um melhor entendimento de conceitos relacionados a uma questão pode contribuir para uma melhor tomada de decisão (PATRONIS et al., 1999; ZOHAR \& NEMET, 2002), no trabalho de Kuhn (1993) o domínio que especialistas tinham em suas áreas de conhecimento não pareceu influenciar a habilidade de raciocínio.

Segundo Sadler \& Zeidler (2005), a maioria dos estudos fornece apenas evidências tangenciais para a presumida relação entre raciocínio informal e conhecimento do conteúdo em questões sociocientíficas, relação que não seria suportada por outros autores da área de pesquisa sobre raciocínio informal e argumentação, como Kuhn (1991 apud SADLER \& ZEIDLER, 2005).

Em seu trabalho, Sadler \& Zeidler (2005) analisaram a relação entre conhecimento do conteúdo científico e a qualidade do raciocínio informal, além da relação entre conhecimento do conteúdo e padrões de raciocínio informal apresentados em um contexto de questão sociocientífica envolvendo terapia gênica e clonagem. Como resultado, os participantes da pesquisa com conhecimentos mais avançados de genética demonstraram menos falhas de raciocínio (avaliadas através das dimensões: "coerência intracenário", "não-contradição inter-cenário”, "construção de contraposições" e “construção de refutadores"). Além disso, era mais provável encontrar sujeitos com maior domínio do conteúdo incorporando aspectos conceituais em seus padrões de raciocínio do que participantes com ideias mais ingênuas sobre genética.

Uma boa parte dos trabalhos também mostra que as pessoas tomam decisões baseadas primariamente em valores pessoais, moral, ética e preocupações sociais 
(BELL \& LEDERMAN, 2003; SADLER \& ZEIDLER, 2004). No trabalho de Bell \& Lederman (2003), a evidência científica, apesar de ser considerada, recebe um papel secundário na tomada de decisões. Para os mesmos autores, o desenvolvimento de melhores habilidades de tomada de decisões deve envolver outros fatores além do conteúdo científico, inclusive mais instrução baseada em valores e atenção ao desenvolvimento intelectual/moral.

Para além do conhecimento do conteúdo científico, Sadler \& Zeidler (2004) observaram que fatores morais são importantes influências na tomada de decisões referente a questões de engenharia genética. Os mesmos autores (2005) destacam que os estudos sobre os padrões de pensamento dos estudantes sobre questões sociocientíficas têm mostrado tendências como a significativa influência das experiências pessoais, considerações emotivas, viés social, predomínio da moralidade em muitos contextos sociocientíficos, além de variabilidade nas percepções dos estudantes sobre a complexidade inerente às questões (BELL \& LEDERMAN, 2003; HOGAN, 2002; KORTLAND, 1996; PATRONIS et al., 1999; SADLER, CHAMBERS \& ZEIDLER, 2004; SADLER \& ZEIDLER, 2004; YANG \& ANDERSON, 2003; ZEIDLER \& SCHAFER, 1984; ZEIDLER et al., 2002).

Outra grande e importante área de investigação refere-se à argumentação sociocientífica. Segundo Kuhn (1993), tópicos sociocientíficos são interessantes para criação de atividades argumentativas no ensino de ciências, já que são assuntos nos quais as pessoas em geral se enxergam como competentes para manter opiniões e fazer julgamentos. Patronis et al. (1999) acrescentam que a interação dos diferentes tipos de argumentos na discussão dos estudantes é essencial para que os alunos encarem a complexidade das questões sociais.

De acordo com a revisão de Sadler (2004), uma parte dos estudos existentes envolve análise dos argumentos após instrução explícita dos sujeitos sobre argumentação e questões sociocientíficas. Tais trabalhos revelam duas tendências distintas:

- aumento no nível de conhecimento sem melhorias nas habilidades argumentativas (KORTLAND, 1996), e;

- melhorias no nível de conhecimento e nas habilidades argumentativas (ZOHAR \& NEMET, 2002).

Kortland (1996) investigou padrões de argumentação de alunos de 13 e 14 anos tratando de questões ambientais relativas à destinação de resíduos e reciclagem. Os 
alunos ofereceram critérios válidos para suportar as afirmativas, mas não forneciam refutadores e apresentavam clareza suspeita. O autor concluiu que os estudantes possuíam a habilidade de construir um argumento básico, apesar de notar limitações no que se refere a alcance, clareza e aplicações dos argumentos apresentados. O nível dos argumentos se manteve o mesmo após uma intervenção focada em formação de argumentos e conteúdo, mas o entendimento da questão sociocientífica foi melhorado, levando a decisões mais coerentes.

Resultados melhores tanto na argumentação quanto no entendimento conceitual foram obtidos no trabalho de Zohar \& Nemet (2002). Nessa pesquisa, os alunos foram expostos a uma intervenção com conceitos avançados relacionados a engenharia genética, genética humana aplicada e questões sociais derivadas. Os autores também elegeram um grupo experimental, para o qual foi fornecida instrução explícita sobre habilidades argumentativas, além do conteúdo de genética.

Nesse estudo, testes anteriores à intervenção mostraram que a maioria dos alunos (90\%) conseguia formular argumentos simples, definidos como afirmativas suportadas por alguma justificação, apesar de apenas alguns $(16,2 \%)$ fazerem referência a conhecimentos específicos e corretos de biologia para sustentarem suas posições. Após a fase instrucional, todos os alunos melhoraram seus conhecimentos de genética, sendo que aqueles que receberam instruções sobre argumentação tiveram melhores notas. Além disso, o grupo experimental demonstrou melhoria qualitativa no uso de habilidades argumentativas, mostrando que um currículo desenhado adequadamente integrando conteúdo sociocientífico e argumentação pode melhorar tanto o entendimento conceitual como a própria capacidade argumentativa dos alunos.

Sadler (2004) aponta também para outra vertente dos estudos com argumentação sociocientífica: aqueles nos quais não é oferecida aos sujeitos instrução explícita sobre habilidades argumentativas, mas ocorre a análise dos argumentos a partir da exposição e discussão dos temas sociocientíficos. Dois exemplos típicos dessa área são os trabalhos de Patronis et al. (1999) e Jiménez-Aleixandre et al. (2000).

Em Patronis et al. (1999) temos alunos gregos da faixa de 14 anos discutindo um problema local, referente ao planejamento de uma estrada a ser construída perto da escola. De forma contrária aos resultados de Kortland (1996), aqui os estudantes parecem desenvolver argumentos bem formulados sobre questões sociocientíficas.

Baseados no padrão de argumento desenvolvido por Toulmin (1958), os autores identificaram duas dimensões em relação aos argumentos. A primeira se refere ao 
processo de argumentação. Quanto a essa dimensão, os argumentos podem ser de "defesa" ou "ataque". Também podem ser classificados como "estáveis" quando permanecem constantes durante alguma fase da interação ou como "inventados", quando os estudantes tentam responder a outras posições. A segunda dimensão se refere à natureza do argumento, que pode ser qualitativo, semi-quantitativo ou quantitativo.

Argumentos qualitativos poderiam ser considerados como ferramentas de pensamento baseadas em aspectos sociais, ecológicos, econômicos ou práticos da situação discutida. Geralmente também envolvem valores, como conservação do ambiente natural, importância do dinheiro, felicidade pessoal ou bem-estar coletivo. Argumentos semi-quantitativos seriam representados quando os estudantes utilizam quantidades variáveis, isoladamente ou em relações. Tal dimensão seria importante por ajudar o estudante a focalizar os aspectos essenciais de uma questão, sem envolver a complexidade de relações exatas. Por fim, argumentos quantitativos apresentariam cálculos baseados em fórmulas ou estimativas, presentes no referido estudo quando os alunos discutiam o desenho de uma ponte, por exemplo.

Patronis et al. (1999) concluíram que os alunos são aptos para formular argumentos e atingir decisões quando encontram uma situação com a qual realmente estão envolvidos. Assim, ligações pessoais com as questões discutidas poderiam levar a habilidades argumentativas melhoradas.

Jiménez-Aleixandre, Rodríguez \& Duschl (2000) analisaram alunos em pequenos grupos discutindo questões relacionadas a genética. Dois aspectos principais foram observados nas interações: as "operações argumentativas" e as "operações epistêmicas". As primeiras representavam a estrutura dos argumentos dos estudantes como definida por Toulmin (2003), composta por dados, garantias, conclusões, apoios, qualificadores e refutadores. A análise das operações epistêmicas concentrava-se no tipo de conhecimento ou operação cognitiva usada em um argumento, como, por exemplo, procedimentos explicativos, relações causais, definições, classificações, consistência, plausibilidade, apelos a analogias, exemplares e autoridade, todas que podem ser interpretadas como características dos processos de construção de conhecimento em ciências experimentais.

As discussões nos pequenos grupos de alunos mostraram variados padrões de argumentação no que se refere à qualidade. Os argumentos variaram de sofisticados, quando incluíam justificações e apoios, a ingênuos, quando continham afirmativas isoladas sem o suporte de dados ou apoios. No geral, a maioria dos argumentos 
apresentados não era de boa qualidade, havendo baixa ocorrência de garantias e nenhum qualificador ou refutador. Os alunos se mostraram limitados em termos de operações epistêmicas também, com a maioria de seus argumentos focando em relações de causalidade e apelos a analogias, enquanto pouco se preocuparam com questões de consistência e plausibilidade.

Os trabalhos acima referidos constituem parte da ampla gama de pesquisas possíveis explorando questões sociocientíficas no ensino de ciências. Tanto pelas relações com a qualidade da argumentação e do raciocínio informal como por considerarem a importância das questões morais na Ciência, parece importante fornecer oportunidades para que os alunos pratiquem a discussão de tais questões. Segundo Walker \& Zeidler (2007), se nós queremos que os alunos pensem por si mesmos, então as atividades didáticas embebidas em um contexto sociocientífico forneceriam as oportunidades para que eles se envolvam em raciocínio informal, discurso, argumentação e raciocínio baseado em evidências nas aulas de ciências. Este trabalho se concentra na utilização de tais contextos na sala de aula, especificamente na argumentação produzida em uma discussão sociocientífica, nos valores, conceitos e padrões morais que influenciam os alunos e são utilizados na abordagem de um tema com implicações morais, no caso, o aborto.

\section{Moralidade das Questões Sociocientíficas e o Aborto como Questão Sociocientífica}

Alguns investigadores (ANDREW \& ROBOTTOM, 2001; ZEIDLER \& KEEFER, 2003) assumem que as questões sociocientíficas, por definição, envolvem moralidade, e vários estudos têm suportado isso empiricamente. Bell \& Lederman (2003) observaram que $85 \%$ das respostas de seus participantes a questões relacionadas a biotecnologia e saúde humana envolviam considerações morais, éticas ou de valores. Hogan (2002) encontrou que estudantes adolescentes empregam ativamente raciocínio moral quando trabalham com questões ambientais. Sadler \& Zeidler (2004), de forma mais específica, exploraram os aspectos morais da tomada de decisões no contexto de questões de engenharia genética. Os sujeitos de tal pesquisa consideraram a questão sociocientífica como uma questão moral, apresentando tipos de raciocínio 
consequencialistas, baseados em princípios, emotivos e intuitivos (SADLER \& ZEIDLER, 2005).

Grande parte da evidência coletada na área de questões sociocientíficas sugere que os processos de tomada de decisão sociocientíficos são primariamente guiados por fatores sociomorais e pelo domínio afetivo, sendo que o conhecimento de conteúdo científico parece contribuir minimamente para as decisões reais que os indivíduos tomam em contextos sociocientíficos (BELL \& LEDERMAN, 2003; SADLER \& FOWLER, 2006; WALKER \& ZEIDLER, 2007).

No trabalho de Sadler \& Fowler (2006), por exemplo, indivíduos com diferentes níveis de conhecimento de genética tenderam a focar em temas sociomorais de forma similar, quando negociavam questões de engenharia genética socialmente complexas. Pedretti (1999) cita a análise de consequências entre alunos adolescentes considerando uma questão ambiental. Os estudantes se utilizaram de princípios básicos de justiça.

Em seu trabalho sobre a moralidade das questões sociocientíficas, Sadler \& Zeidler (2004) estudaram como os estudantes acessam a moralidade em questões envolvendo genética. Eles constataram que os fatores morais são de fato influências importantes na tomada de decisões envolvendo questões de engenharia genética. Além disso, deixam claro que, para um indivíduo tomar uma decisão informada sobre uma questão sociocientífica, ele deve considerar as ramificações morais dessas decisões.

Os sujeitos da pesquisa manifestaram padrões de tomada de decisões baseados na moral, identificados pelos autores como: raciocínio moral, que podia ser baseado em consequiências ou em princípios, escolha moral emotiva e escolha moral intuitiva. A emergência de padrões morais está subordinada ao participante enxergar a questão como um problema moral. Alguns alunos entrevistados pelos pesquisadores, além de considerar as questões referentes à clonagem e terapia gênica como questões morais, integraram a ideia de escolha pessoal em suas tomadas de decisões. Assim, tais estudantes sugeriam que os cenários de engenharia genética eram morais, mas os árbitros últimos de tal moralidade deveriam ser os indivíduos envolvidos.

A moralidade em si é uma questão complexa que remete à área de estudo dos filósofos e psicólogos morais. As categorias de padrões morais desenvolvidas por Sadler \& Zeidler (2004) são oriundas desse campo de conhecimento (HAIDT, 2001; FORD \& LOWERY, 1986; TISAK \& TURIEL, 1988). Uma das abordagens mais usadas atualmente é o modelo social-interacionista (HAIDT, 2001). Segundo tal perspectiva, o conhecimento social e a tomada de decisões residem em um dos três 
domínios: convencional, pessoal e moral (SADLER \& ZEIDLER, 2004). As decisões convencionais referem-se a tratos sociais e uniformidades de comportamento dentro de sistemas culturais. É uma violação convencional, por exemplo, um aluno ir à escola de pijama, ao invés de vestir seu uniforme (TISAK \& TURIEL, 1988). Decisões pessoais são aquelas de prerrogativa individual, que competem somente à pessoa tomar. A escolha de uma roupa ou dos alimentos a serem consumidos em uma refeição são exemplos, pelo menos no mundo ocidental, de tomadas de decisão pertencentes ao âmbito pessoal. Por fim, violações morais são aquelas que levam a injustiça, prejuízo ou violação de direitos, sendo tratadas de forma diferente de outros tipos de violações (HAIDT, 2001).

As questões sociocientíficas estão relacionadas a justiça, bem-estar e direitos, portanto, são questões morais. No trabalho de Sadler \& Zeidler (2004), os estudantes manifestaram diferentes padrões morais ao abordar as questões sobre engenharia genética. Lembrando que a forma de resolução das questões sociocientíficas é o raciocínio informal, e considerando que esse termo subentende processos cognitivos e afetivos, temos (SADLER \& ZEIDLER, 2005):

Raciocínio Informal Racionalista: descreve considerações baseadas na razão.

Raciocínio Informal Emotivo: abordagem relacional, referente à empatia e à simpatia. Os indivíduos genuinamente se preocupam com o bem estar dos outros, havendo uma tendência a focar no elemento humano das questões.

Raciocínio Informal Intuitivo: assim como o emotivo, é uma resposta afetiva, como uma reação imediata inexplicável.

No referido trabalho, os padrões identificados como raciocínio informal racionalista ainda podiam representar uma abordagem consequencialista ou deontológica. $\mathrm{O}$ raciocínio consequencialista se refere principalmente às consequiências das decisões, preferindo escolhas que tenham melhores conseqüências. Desse ponto de vista, o ato moralmente certo é aquele que produz o melhor resultado possível. Já a posição deontológica implica o reconhecimento de qualidades inerentes e de valor intrínseco dos seres considerados. As escolhas são tomadas independentemente do resultado geral, mas de acordo com regras morais e princípios (SADLER \& ZEIDLER, 2004; ANDREW \& ROBOTTOM, 2001). 
O estudo dos padrões e processos que os estudantes utilizam quando confrontam dilemas controversos em Ciência promete auxiliar no desenvolvimento de currículos sociocientíficos e estratégias pedagógicas apropriados, promovendo a alfabetização científica, de acordo com Sadler \& Zeidler (2004). Para tais autores, um melhor entendimento de como os indivíduos acessam a moralidade nas questões sociocientíficas está relacionado a um avanço para uma posição onde pedagogia e currículo ajudam o estudante a integrar ideias sobre questões científicas e seus próprios valores e ética.

Também no sentido de conhecer tais processos e padrões, uma parte dos trabalhos da área de questões sociocientíficas busca identificar os valores que estão por trás dos argumentos utilizados pelos estudantes para defenderem suas posições.

Simonneaux (2001) analisou, em termos de "ordens de importância" relacionadas aos diferentes argumentos, os valores dos alunos com relação a questões de biotecnologia. Ele também identificou economia, ecologia, genética, ciência, medicina e ética como os campos de referência que fundamentavam tais argumentos.

Mary Ratcliffe (1996) procurou conhecer que valores os estudantes traziam para suportar suas tomadas de decisão em questões sociocientíficas. A autora obteve como valores: custo-benefício (o mais freqüente), segurança e considerações ambientais, justiça social e ambiental, altruísmo, egoísmo, considerações ambientais sobre energia e estética. Como esperado, os valores apareciam em freqüências diferentes de acordo com o assunto abordado.

Há diversos temas sociocientíficos férteis para a investigação dos valores e padrões morais dos estudantes. Na literatura sobre questões sociocientíficas em geral, temos como assuntos mais comuns: biotecnologia e engenharia genética (SADLER \& ZEIDLER, 2004; SADLER \& ZEIDLER, 2005a; SADLER \& ZEIDLER, 2005b; ZOHAR \& NEMET, 2002; SADLER \& DONELLY, 2006; SADLER \& FOWLER, 2006), experimentação animal (SIMONNEAUX, 2001; ZEIDLER et al., 2002), alimentos geneticamente modificados (WALKER \& ZEIDLER, 2007), a relação entre hábitos e saúde (BELL \& LEDERMAN, 2003), utilização de tecnologias e riscos à saúde (KOLSTO, 2006; POULIOT, 2008) e dilemas ambientais (GEDDIS, 1991; HOGAN, 2002; KOLSTO, 2001; BELL \& LEDERMAN, 2003; OSBORNE et al., 2004; RATCLIFFE, 1996; RATCLIFFE， 1997; GRACE \& RATCLIFFE，2002; SADLER et al., 2007; SADLER et al., 2004; WU \& TSAI, 2007; YANG \& ANDERSON, 2003; KORTLAND, 1996). 
Em prol do aumento da diversidade de temas explorados, Patronis et al. (1999) acrescentam que muito conhecimento e informação ainda precisam ser desenvolvidos sobre a natureza de questões sociocientíficas particulares. Uma questão muito pouco explorada na literatura da área é o aborto.

O trabalho de Bell \& Lederman (2003), através de questionários e entrevistas, explorou um cenário sobre implantação de tecido fetal para o tratamento do mal de Parkinson. Tal cenário continha um forte componente moral/ético, além de fornecer oportunidades para os respondentes comentarem sobre uma variedade de questões sobre a natureza da Ciência, incluindo a natureza subjetiva da definição de vida e as formas pelas quais a Ciência pode informar dilemas éticos.

No referido estudo, os participantes usaram principalmente fatores éticos e morais, valores e questões sociais ou políticos para a tomada de decisões. As principais estratégias de raciocínio utilizadas foram consideração da evidência, conservadorismo, análise de risco, análise custo-benefício, e decisão baseada em valores.

Além desse trabalho, que faz apenas um uso tangencial do tema, o aborto como questão sociocientífica não tem sido explorado de forma significativa, talvez por seu caráter mais social do que científico ou por envolver questões religiosas e discussões fortemente polêmicas.

É importante, no entanto, que tais obstáculos não sejam impeditivos da utilização do aborto como questão sociocientífica na sala de aula. De acordo com Kuhn (1993), para permitir que os estudantes vejam a significância do pensamento científico, nós podemos, eventualmente, precisar nos afastar dos domínios tradicionais da Ciência.

Segundo Oulton et al. (2004), o ensino sobre questões sociocientíficas deve enfatizar, entre outras coisas, que:

- os grupos dentro da sociedade podem suportar diferentes posições sobre tais questões;

- tais posições são baseadas em conjuntos diferentes de informações, que, por sua vez, são interpretadas de maneiras diferentes;

- as interpretações diferentes podem ser causadas por diferentes visões de mundo;

- visões de mundo divergentes podem ocorrer porque os indivíduos aderem a diferentes sistemas de valores;

- questões controversas nem sempre podem ser resolvidas recorrendo-se à razão, à lógica ou a experimentos. 
Assim, é importante que diversas questões sejam exploradas, e que seu aspecto polêmico seja utilizado para ampliar a visão dos alunos e enriquecer a discussão, trazendo à tona as variadas possibilidades de abordagem. Nesse sentido, o fato de o aborto ser um assunto um tanto controverso na nossa sociedade pode ser considerado como um aspecto favorável à sua utilização como questão sociocientífica.

Além disso, o aborto também preenche os requisitos utilizados geralmente para se considerar um tema como uma questão sociocientífica. Trata-se de um dilema social que possui ligações conceituais - no caso, relacionadas aos processos de fecundação, nidação, gestação, e à complicada ideia de início da vida - e tecnológicas com a Ciência - como será visto mais adiante, os avanços tecnológicos podem alterar a representação social do feto, além de servirem como um dos critérios para a definição dos limites da vida (SADLER, 2004; SADLER \& ZEIDLER, 2004). O aborto possui natureza polêmica, é uma questão aberta a múltiplas perspectivas e não possui conclusão simples, envolvendo moralidade e ética (SADLER \& ZEIDLER, 2004).

Dado que a própria educação em si não é neutra, mas sim um ato político, movido por valores (ANDREW \& ROBOTTOM, 2001), é extremamente importante e recomendado que os currículos de ciências não apenas incorporem diferentes questões sociocientíficas, mas também atentem, explicitamente, para os aspectos morais de tais questões (SADLER \& ZEIDLER, 2004).

\section{Considerações acerca dos Limites da Pessoa e o Aborto}

A validade ética do aborto é uma das questões mais discutidas no terreno interdisciplinar que envolve a biologia, a filosofia e a medicina, entre inúmeras outras áreas do conhecimento. De um item de planejamento familiar a um problema de saúde pública mundial, o tema é amplo e complexo o suficiente para suscitar manifestações de profissionais de saúde, políticos e religiosos. Nas mídias científicas ou não, muitas ideias são veiculadas a respeito, sendo que as bem elaboradas geralmente contam com uma análise interdisciplinar cuidadosa e sistemática que considera relevantes, além das consequiências da realização de um aborto e da legislação sobre o aborto, a definição do status do feto, do embrião, do pré-embrião ou ainda do zigoto.

No Brasil, o maior país católico do mundo, são feitos por ano cerca de 5 milhões de abortos, em contraste com 3,5 milhões de nascimentos. Esses números, associados a 
um total de 300 mil mulheres internadas em hospitais públicos com complicações pósabortivas por ano e a uma das maiores taxas de mortalidade materna da América Latina (150 por 100 mil nascidos vivos) indicam a dimensão do problema no país e a relevância de tratamentos adequados do tema (LAURENTI, 1995 apud LEAL, 1998).

Um fator complicador é que a visão que as pessoas têm sobre assuntos morais tão complexos como o aborto geralmente é "embaçada" por interesses próprios, inércia, falta de empatia, ideias defensivas e caricaturais (WILAND, 2000). No sentido de dissipar preconceitos e esclarecer, filósofos, educadores e cientistas fazem um importante trabalho ao discutir a questão.

A importância da análise interdisciplinar do tema está relacionada ao fato de que a principal questão envolvendo o aborto não é apenas uma pergunta simples, mas múltipla. Através da pergunta “Quando começa a vida humana?”, estamos interessados em diferentes questões capazes de serem respondidas por diferentes áreas, como a questão "Quando começa a vida humana, do ponto de vista biológico?", que é uma pergunta científica, e a questão “Quando o ser humano adquire direitos de pessoa?”, que é uma pergunta filosófica, não menos importante que a primeira. Obviamente, outras áreas que não a Ciência ou a Filosofia, como a Teologia, podem, de forma legítima, reclamar o direito de responder a tal questão.

\subsection{Aspectos Políticos e Jurídicos}

Desde os anos 40 do século passado, a legislação brasileira não pune o aborto em dois casos: quando não há outra forma de salvar a vida da mãe (aborto necessário) e se a gravidez for fruto de um estupro. O aborto legal, como é chamado nesses casos, encontra-se definido no Código Penal de 1940 (artigos 124 a 128), o principal documento jurídico que trata sobre o assunto no país, proibindo a interrupção da gestação em todas as outras circunstâncias (ROCHA \& NETO, 2003).

Apesar de o Código Penal incriminar o aborto, a eficácia de tal lei é questionável. Em primeiro lugar, porque o aborto é amplamente praticado e raramente existe punição judicial. Além disso, nos dois casos em que ele é permitido, o aborto legal é relativamente pouco praticado por questões de acesso a serviços, de receio de incriminação ou desconhecimento dos trâmites legais (ROCHA \& NETO, 2003). 
Um texto legal que é bastante utilizado por aqueles que defendem a inviabilidade jurídica da descriminalização do aborto no país é o artigo $5^{\circ}$ da Constituição Federal. Ele estabelece que "Todos são iguais perante a lei, sem distinção de qualquer natureza, garantindo-se aos brasileiros e aos estrangeiros residentes no País a inviolabilidade do direito à vida, à liberdade, à igualdade, à segurança e à propriedade, nos termos seguintes(...)". Apesar de ser utilizada como um argumento anti-aborto, observa-se que a Constituição não faz nenhuma referência expressa à proteção da vida desde a concepção (LOREA, 2006).

A falta de menção explícita à concepção ou ao indivíduo antes de nascer torna discutível se a proteção do direito à vida se estende ao feto. De uma forma ou de outra, é importante destacar que os direitos fundamentais garantidos na Constituição não são absolutos, já que nas situações de guerra ou legítima defesa o direito à vida se vê relativizado. Outro fato interessante é que o Código Penal prevê diferentes penalidades para a pessoa que comete homicício, infanticídio e aborto, o que permite concluir que o ordenamento jurídico aceita uma gradação no direito à vida.

O tema também aparece na Lei de Contravenções Penais (de 1941), onde considera-se contravenção sujeita à penalidade o anúncio de processo, substância ou objeto destinado a provocar aborto (artigo 20). A Consolidação das Leis do Trabalho (de 1943), no capítulo relativo às "Férias anuais", ao tratar das faltas ao serviço não consideradas para efeito de concessão de férias, garante o licenciamento da empregada por motivo de maternidade ou de aborto previsto em lei (artigo 131, inciso II) (ROCHA \& NETO, 2003).

A discussão política sobre o aborto se desenrola com destaque no Congresso Nacional onde, através da representação de diferentes atores da sociedade, várias propostas de alteração da legislação sobre o aborto já tiveram lugar. Algumas das ideias foram no sentido de: tornar o aborto um crime hediondo; proibir o aborto em todos os casos; permitir o aborto em qualquer caso até a décima ou décima segunda semana de gravidez; permitir aborto no caso de gestante com HIV e de risco à saúde física e mental da mulher (ROCHA \& NETO, 2003).

Entre os principais atores sociais e políticos envolvidos na discussão destacamse a Igreja Católica, segmentos da categoria médica, o movimento feminista e religiosos evangélicos, cada grupo com motivos próprios de interesse (ROCHA \& NETO, 2003). Recentemente (agosto de 2008) o aborto entrou em pauta para ser discutido no Supremo Tribunal Federal, com relação à descriminalização da prática nos casos de anencefalia 
do feto. Até então, mulheres grávidas de fetos anencéfalos só poderiam abortar após processos judiciais, que nem sempre lhes eram favoráveis.

\subsection{Status Moral e o Conceito de "Pessoa"}

Matar uma pessoa que não seja um agressor é considerado um ato terrível e repreendido na imensa maioria das sociedades. Restrições morais com relação a matar qualquer ser vivo, no entanto, são observadas em apenas um pequeno número de culturas, sendo que grande parte dos povos admite matar determinados animais para alimentação, utilização de insumos como peles e óleos e ainda por outros motivos, como para pesquisas científicas. E quanto ao próprio ser humano em suas fases iniciais de desenvolvimento? A morte representa a mesma coisa em qualquer estágio? A partir de que momento ele deve receber os mesmos direitos morais de um ser humano completamente desenvolvido?

Muitos defensores e opositores da legalidade do aborto geralmente concordam com o fato de este ser moralmente indesejável. A divergência ocorre quanto a considerá-lo um assassinato ou não. A principal razão da disputa está no momento a partir do qual se pode chamar o indivíduo humano de pessoa. Segundo Belshaw (1997), a disputa em relação ao status de pessoa está no cerne da maioria das questões sobre o assunto. A distinção entre humano e pessoa é lugar-comum nas discussões sobre aborto (CLARKE, 1999) e parece extremamente relevante à medida que delimita o status moral do ser humano.

Nos debates sobre nossas obrigações com relação a animais não-humanos e embriões humanos, há um movimento entre conferir status moral e valor moral. No primeiro caso, o indivíduo merece consideração moral direta e é tomado como membro de nossa comunidade moral. No segundo caso há consideração moral, mas o indivíduo não é considerado pertencente à comunidade moral. Há autores também que defendem que os embriões humanos seriam dotados apenas de valor simbólico, o que tornaria o respeito a essas entidades sempre subordinado ao respeito que temos a indivíduos com valor intrínseco, como nós mesmos (BORTOLOTTI, 2007).

Himma (2005) coloca a ideia de "personhood" como um nível particular de posição moral, talvez algo equivalente ao status moral, um conceito ambíguo por poder significar "genetic personhood" ou "moral personhood". No primeiro caso, basta que 
um ser vivo possua DNA humano para ser possuidor de tal atributo. O segundo conceito, para o autor, está relacionado à capacidade de um sujeito de vivenciar experiências.

Para Bortolotti (2007), os critérios para se conferir a um indivíduo status moral deveriam ser aplicáveis com base em nosso conhecimento científico atual, ter uma justificação ética sólida, e ainda estar de acordo com algumas de nossas intuições morais e práticas sociais. Para a autora, "personhood" falha nesses itens, não podendo ser considerado como critério de status moral. Para caracterizar a presença de status moral, Bortolotti prefere utilizar o critério "atividade intencional", que também se apresenta problemático em alguns aspectos. Outros autores (GILLON, 2001; HIMMA, 2005) consideram válida a relação entre o conceito de status moral e a ideia de pessoa.

Tendo em mente que a decisão com relação ao aborto deve estar relacionada com as ideias de status moral e o conceito de pessoa, além de outros conceitos que se façam necessários, como o de indivíduo, segue-se abaixo uma tentativa de explorar as questões inerentes a cada um dos limites comumente utilizados para definir o início da vida humana.

\subsubsection{A Alma na Concepção e o Essencialismo}

A ideia de que o limite para o início da vida seria o momento da concepção é adotada por grande parte das pessoas com orientação anti-aborto, por diversas religiões evangélicas e também pela Igreja Católica atualmente. Essa posição geralmente está relacionada com o pensamento da concepção como o momento em que o indivíduo receberia uma alma (o equivalente teológico de se tornar uma pessoa). Essa ideia, compartilhada por várias outras religiões, foi expressa pela Igreja Católica em 1974 na Declaração sobre Aborto pela Congregação Romana para a Doutrina da Fé e também antes, em 1869, quando o papa Pio IX declarou que o aborto é pecado em qualquer situação e em qualquer momento em que se realize, respaldando a tese da "hominização imediata" (ROSADO-NUNES, 2006).

É interessante observar que estudos na área de história e teologia mostram que tal visão não é muito antiga. Nos primórdios do cristianismo, a principal preocupação em relação ao aborto era devida ao crime de adultério que a prática do aborto visava esconder, voltando-se apenas depois para o problema do possível assassinato cometido 
com a interrupção da gravidez. Santo Tomás de Aquino, um dos maiores filósofos da Igreja na Idade Média, muito influenciado pelas ideias de Aristóteles, considerava que o ser humano só recebia a alma após quarenta dias da concepção no caso dos homens e oitenta dias no caso das mulheres (LISKER, 2003). Tal pensamento, compartilhado por Santo Agostinho, representava a posição da "hominização retardada" ou "posterior", que não considerava o aborto antes da união da alma com o corpo como um homicídio apesar de considerá-lo um pecado contra o casamento (HURST, 2006). Santo Agostinho escreveu:

Segundo a lei, o ato (de aborto) não é considerado homicídio, pois não se pode dizer que existe uma alma viva em um corpo que carece de sensações já que ainda não se formou sua carne e ele não está dotado de sentidos (SANTO AGOSTINHO, On Exodus, 21.80 apud HURST, 2006)

A posição da Igreja com relação ao início da vida humana, assim, não foi sempre a mesma (ROSADO-NUNES, 2006).

Um detalhe importante que poderia ser corrigido no pensamento de que o início da vida humana ocorre no momento da concepção é que tal momento não existe. Há sim, um processo biológico que se desenrola em um tempo determinado e que não é estanque. A defesa da posição anti-aborto poderia se aproximar mais da realidade biológica se apropriando desse item. Outro problema persistente é a falta de critérios para se considerar o zigoto como um tipo de vida mais valiosa do que a dos espermatozóides e dos oócitos. Afinal, se considera que a vida humana começa com a fecundação, quando, na verdade, em nenhum momento a vida (do ponto de vista biológico) parou de ocorrer.

Uma boa parte dos argumentos que defendem o início da vida da pessoa no momento da concepção assemelha-se, de certa forma, com as ideias do essencialismo. O essencialismo é um enfoque filosófico que defende que todas as classes naturais podem definir-se em termos das propriedades que possuem todos os membros da classe e somente eles. Em Beckwith (2005), encontramos a seguinte frase: "Consequentemente, um ser humano possui valor intrínseco em função do tipo de coisa que é, e permanence sendo tal tipo de coisa enquanto existir" (p.57).

Assim, desde o momento da concepção, o ser humano já apresentaria algo que o define e o acompanha em todas as fases da vida. O ser humano é apresentado como um “tipo" portador de uma essência humana. Essa essência, para os religiosos, seria a alma, 
conferida no momento da concepção e presente até a morte. Mas o que poderia representar a essência do ser humano sob uma perspectiva não-religiosa?

Para responder a essa pergunta, devemos considerar que, para um atributo ser considerado uma essência ele deve ser imutável em todas as fases da vida (se houver alteração, o tipo não poderá mais ser considerado o mesmo), não acidental, explicativo e intrínseco do ser humano (SOBER, 1996). O único atributo humano que se aproxima dessas exigências é o genoma. A princípio, então, o tipo de argumento anti-aborto que encontramos em Beckwith (2005) poderia estar fundado em uma concepção essencialista da pessoa humana que adota o genoma como sendo a essência desta.

De fato, o genoma permanece relativamente constante ao longo dos estágios da vida, é um atributo não acidental, intrínseco e, segundo acredita o nosso atual conhecimento biológico, explicativo de grande parte do que uma pessoa é. No entanto, o genoma não explica a totalidade de um ser humano, ainda mais se consideramos importante o conjunto de experiências e significados vividos por uma pessoa. Além disso, um importante aspecto do genoma torna complicado adotá-lo como a essência do ser humano: o fato de o genoma ser extremamente variável dentro da espécie humana. Se a espécie humana fosse um tipo, uma classe natural, deveria haver uma essência, ou seja, uma propriedade necessária e suficiente para definir determinado ser como pertencente a esta classe. Contudo, nem mesmo o genoma pode ser invocado como o atributo essencial, já que cada ser humano difere dos outros quanto à exata sequência dos pares de bases em seu material genético.

Segundo Sober (1996), qualquer espécie biológica é uma entidade histórica, um indivíduo, e, assim, não se enquadra no conceito essencialista de classe natural ou tipo. Dessa forma, não há, na espécie humana, qualquer característica que possa ser considerada essencial e definidora do ser humano como classe natural. Não havendo nenhum atributo que seja comum a todos os estágios da vida de todos os seres humanos, ou seja, não havendo nenhuma "essência" humana, nada impede que diferentes estágios de desenvolvimento tenham status diferenciados de acordo com as propriedades que apresentam. Tal conclusão permite a ideia de não conferir ao zigoto o mesmo status de pessoa que conferimos a um adulto, por exemplo. 


\subsubsection{A Implantação no Útero como Limite Possível}

Há muita controvérsia com relação aos métodos anticoncepcionais que atuam na fase imediatamente posterior à fecundação. Caso a gestação seja definida a partir do momento da implantação no útero e o aborto seja definido como a interrupção da gestação, as "pílulas do dia seguinte" podem ser classificadas como não-abortivas. No entanto, se a gestação for definida como ocorrendo a partir da fecundação e/ou o aborto for definido como a interrupção da vida de um novo ou potencial ser humano, então as “pílulas do dia seguinte" deslizam para a outra categoria, a dos métodos abortivos.

A questão envolvendo este limite parece ao mesmo tempo problemática e meramente classificatória ou semântica.

\subsubsection{Dias - O Pré-Embrião e a Formação do Embrião como Limite}

Passados 14 dias da fecundação, o processo de implantação já estará completo e o pré-embrião passa a ser chamado embrião. Essa distinção é importante por marcar o surgimento da notocorda e, talvez, uma alteração de status. Além da ausência de notocorda, o pré-embrião pode se dividir, formando gêmeos monozigóticos, enquanto no embrião isso não ocorre. Para Kurjak et al. (2007), o pré-embrião não é uma vida individual, mas apenas uma forma de vida "distinta". Apenas o embrião poderia ser chamado de indivíduo, já que, para tal autor, o conceito de indivíduo requer que o ser seja distinto de outras entidades e indivisível. Como o referido autor trabalha na área de ginecologia e obstetrícia, é esperado que tenha utilizado a ideia de indivíduo pensando apenas na espécie humana. No entanto, o conceito acima utilizado ficaria um tanto deslocado se pensado em alguns organismos de reprodução assexuada, que podem, dependendo da espécie, ser cortados ao meio ou em mais de duas partes originando novos indivíduos.

Considerando que seja mais adequado utilizar um conceito mais amplo de indivíduo, são convenientes aqui as ideias de Sober (1996), que define um indivíduo através das relações de causalidade e dos diferentes graus de interdependência funcional entre suas partes. Nesse contexto o próprio pré-embrião poderia ser considerado um indivíduo, o que não significa, necessariamente, que poderia ser considerado uma pessoa. 
A presença de notocorda no embrião, apesar de um fato importante para a embriologia e para a zoologia, caracterizando o embrião humano como pertencente ao Filo Chordata, não parece ser de grande ajuda para definir o status de pessoa ou não do indivíduo em desenvolvimento.

\subsubsection{A Interação Mãe-Feto e a Representação Social do Feto}

Entre 20 e 21 semanas na primeira gravidez e até antes em uma gravidez subseqüente, a mãe começa a sentir os movimentos do feto. Há quem defenda que este momento deveria ser considerado o marco a partir do qual um aborto não deveria mais ser realizado.

É interessante notar aí a importância do aspecto psicológico da mulher na negociação da continuação/interrupção da gravidez. Nessa linha de pensamento, é o significado que o feto adquire para a mulher que confere seu status de pessoa. $\mathrm{O}$ problema desse tipo de argumento é que um indivíduo acaba recebendo ou não determinado status apenas em função de sua relação com o outro, e não em função de si mesmo ou da relação entre suas partes.

Algo semelhante parece existir nas leis e decisões judiciais que permitem o aborto nos casos de estupro ou de anencefalia. A decisão de abortar é tomada visando principalmente a estabilidade psicológica da mulher (sem, é claro, negar a importância deste aspecto), a despeito de o embrião ou o feto serem portadores do status de pessoa ou não. O tipo de raciocínio moral por trás de tais decisões é provavelmente de natureza consequencialista.

Os aspectos psicológicos da mãe estão ainda imersos em uma complexa rede social, cujas relações determinam inclusive se a mãe assume a gravidez ou não. Segundo Leal (1998), “o reconhecimento de que há uma 'pessoa' no processo gestacional depende da avaliação de possibilidades de viabilização de um projeto individual que se desenrola nos âmbitos da família e da casa."

Outros fatores, além do meio social e das expectativas da mulher, parecem influenciar a percepção que se tem do feto. Mills (2005), ao tratar como as tecnologias alteram as relações e responsabilidades que temos com o feto, destaca que a categoria de humano é construída como uma categoria social ao invés de natural. O autor explora o efeito das imagens sobre nossas respostas e intuições éticas. Em seu trabalho, fica 
claro como o uso de tecnologias como a ultrassonografia transforma as relações sociais que alguém pode ter com um feto in utero ao trazer o conhecimento da existência de um outro corpo. A visualização do feto introduz o novo ser no mundo das relações sociais, pelo surgimento da vida corpórea do feto. O efeito desse conhecimento mediado pela tecnologia é uma demanda por resposta ética.

\subsubsection{Sistema Nervoso Funcional - Experiência e Dor como Critérios}

Muitos concordam que não há dúvidas de que o cérebro é responsável por nós, humanos, possuirmos determinados atributos aos quais conferimos um valor moral especial. Himma, em seu trabalho de 2005, mostra que pode ser adequado conferir o status de pessoa moral apenas ao feto que já demonstra atividade cerebral.

A tese do autor se baseia na ideia de que o feto só pode ser considerado uma pessoa quando for um conjunto de corpo e mente (ou alma). Ocorre que não pode haver nenhuma interação de significado entre o corpo e a mente se esta interação não implicar uma relação causal da pessoa (“self”) com o cérebro. Em outras palavras, o cérebro seria essencial para a comunicação da mente com o corpo. Como não pode haver relação causal com o cérebro na ausência de estados mentais ativos, e estes não são possíveis sem atividade elétrica no cérebro, segue-se que o feto não pode ser uma pessoa antes do início da atividade elétrica no sistema nervoso.

A argumentação de Himma é bastante consistente e lógica, defendendo que o aborto não deve ser considerado um assassinato (apesar de não ser desejável) antes do início da atividade cerebral do feto, já que antes disso ele não seria uma pessoa, um sujeito dotado de status moral e capaz de ter experiências.

A abordagem de Himma, ao considerar o indivíduo como uma pessoa apenas a partir do momento em que ele apresenta atividade cortical, vai ao encontro das ideias daqueles que defendem que o feto adquire status moral de pessoa quando tem início a possibilidade de viver experiências, e entre elas a experiência da dor.

Um problema importante desse ponto de vista é que ele se compromete logicamente a considerar muitos outros animais não-humanos como portadores de status moral. Afinal, se a capacidade de sentir dor for considerada suficiente para garantir o direito à vida de um feto humano, por que não garantir o direito à vida de todos os 
outros vertebrados que as pessoas usam para se alimentar, para se vestir ou ainda para fazer pesquisas científicas?

De fato, muitos defensores dos direitos dos animais, abolicionistas animais, opositores da vivissecção e veganos não veriam problema algum nessa conseqüência lógica, que seria apenas uma evidência de como estamos distante de uma moralidade aceitável no trato com os animais não-humanos.

\subsubsection{Viabilidade e a Definição de Limites pela Tecnologia}

Viabilidade é o ponto a partir do qual o feto poderia viver fora do útero. Segundo Clarke (1999), esta visão rejeita o nascimento como ponto de decisão por comparar o feto viável com o bebê nascido prematuro. De fato, parece tentador considerar o feto uma pessoa a partir do momento em que ele independe da mãe, sendo que vários neonatologistas preferem esse critério.

O principal problema está no fato de a viabilidade de um feto ser totalmente dependente do nosso estado tecnológico. Considerar a viabilidade como critério para o aborto é dizer que um feto de 5 meses trinta anos atrás teria menos chance de ser considerado uma pessoa do que o mesmo feto hoje. Da mesma forma, fetos de países desenvolvidos teriam status de pessoa moral mais cedo do que nos países em desenvolvimento, e os fetos destes países mais cedo do que os fetos de países subdesenvolvidos. Deveria a tecnologia ser determinante para se considerar um indivíduo um ser humano dotado de status moral de pessoa?

Assim como a ultrassonografia interfere na nossa percepção de deveres éticos ao introduzir a imagem do feto no mundo social (MILLS, 2005), as tecnologias que viabilizam a vida fetal ex utero podem parecer uma solução ao problema ético do aborto por definir novos limites de independência do feto.

A questão da independência ou não do feto e do embrião é um aspecto complexo e digno de ser explorado. Poderiam os diferentes graus de dependência caracterizar diferentes níveis de individualidade?

Se importarmos novamente o conceito de indivíduo de Sober (1996), teremos que as relações causais e a interdependência fisiológica entre as partes são características importantes de um indivíduo. Ora, ocorre que, quanto mais nos aproximamos do início da gestação, até o momento da nidação, maiores são as relações 
causais e a interdependência entre o novo ser e a mãe. Assim, poderia o embrião ser considerado uma parte de outro indivíduo? Parece lógico que a mãe não poderia ser considerada uma parte do embrião, já que ela pré-existe a este. No entanto, um embrião de poucas semanas depende inteiramente da mãe e é, inclusive, fisicamente ligado a esta. Essas considerações somadas à possibilidade de sobrevivência do feto fora do útero, mediada pela tecnologia, parecem tornar impossível definir um limite para a individualidade. Se a disponibilidade de tecnologia pode abreviar o período de interdependência funcional, ela pode também interferir no status de indivíduo do feto? O próprio Sober (1996) conclui que a individualidade pode ser problemática em alguns casos:

À medida que a interdependência funcional diminui, um conjunto de partes vai deixando de ser paulatinamente um único indivíduo. Quando as partes pertencem a um mesmo organismo e quando são organismos por si mesmas? Não há uma fronteira precisa. (SOBER, 1996, p.245-246)

A ideia de considerar o feto e a mãe como um mesmo indivíduo é compatível com o pensamento daqueles que defendem o direito da mulher sobre seu próprio corpo. Não se pode esquecer, no entanto, que, na Biologia, o limite individual dos organismos sexuados é considerado, por alguns, como bem definido pela fase de união dos gametas, o que não deixa de ser problemático.

De qualquer forma, mesmo se aceitarmos que a tecnologia pode alterar o status de indivíduo do feto, ao permitir sua independência do útero da mãe, ela não pode fazer o mesmo com o status de pessoa moral. Assim, dependendo dos limites tecnológicos considerados poderiam haver fetos individuais com pleno status moral e também fetos individuais (e "independentes" da mãe) sem pleno status moral.

\subsubsection{O Nascimento como Início da Vida}

Talvez pareça o limite mais natural possível, afinal, a maioria das pessoas se preocupa mais com a morte de um ser que podemos ver do que com a morte de um ser que não vemos. O nascimento torna o ser humano uma entidade pública e social, trazida ao conhecimento dos outros, o que implica um dever moral muito mais óbvio com relação àquele ser. Em termos legais, é um critério extremamente prático e fácil de ser aplicado. Mas este limite funciona em termos morais? 
Novamente, o aspecto que é valorizado neste critério não é o status do ser humano, mas uma questão que poderíamos chamar de "geografia biológica" (GILLON, 2001). Considerar que a transformação do feto em uma pessoa com direitos morais ocorre no nascimento é como afirmar a existência de alguma qualidade especial adquirida na passagem pelo útero, que dotaria aqueles que fazem tal passagem do atributo de pessoa. Segundo este critério, aqueles que estão dentro do útero não são pessoas morais, enquanto aqueles que estão fora são. É claramente uma questão de posição, de localização, já que um bebê nascido prematuro de 28 semanas seria salvo e um feto de 30 semanas, segundo esse critério, poderia não ser.

Sob o ponto de vista psicológico e social, em uma abordagem consequencialista, tal limite pode fazer algum sentido, já que o efeito de um bebê em uma família é totalmente diferente do efeito de um feto no útero. Entretanto, o limite não se sustenta em uma análise que leve em consideração o status moral do indivíduo humano.

\subsubsection{Consciência de Si Mesmo e Pensamento Autônomo como Critérios}

Considerando não haver grande diferença entre um feto nos últimos meses de gestação e um recém-nascido, dependendo do critério utilizado para se definir um ser humano com status de pessoa, o próprio recém-nascido pode não ser considerado digno de receber status moral.

Muitos autores consideram necessária a consciência de si mesmo para que um indivíduo seja uma pessoa (BELSHAW, 1997). Este tipo de pensamento está geralmente baseado na noção de que o que é de maior importância moral nos seres humanos é a sua habilidade de refletir racionalmente, estar consciente de suas naturezas morais e suas responsabilidades com os outros e com si mesmos, além de serem capazes de tomar decisões autônomas e terem livre-arbítrio (GILLON, 2001).

Singer (1993 apud CLARKE, 1999) afirma que o recém-nascido não tem nenhuma noção do passado e nenhum desejo (consciente) de continuar vivendo, não sendo, assim, uma pessoa. De forma parecida, Tooley (1983 apud CLARKE, 1999) acredita que uma criatura não é uma pessoa antes de desejar a continuação de sua existência como um sujeito experimentador, tendo a consciência de que é um sujeito experimentador. 
A ideia de matar bebês recém-nascidos é extremamente macabra e não-intuitiva, mas isso, por si só, não é um contra-argumento suficiente do ponto de vista lógico, se não for acompanhado de uma justificativa e um limite para atribuição de status moral. Se considerarmos que, em alguns casos de nascimento de bebês com disfunções congênitas muito severas, há a opção de aplicação de injeção letal para não dar início a uma vida de sofrimento, nos encontraremos no mesmo patamar. É óbvio que o impacto psicológico-social de tal limite poderia ser um tanto terrível, o que o torna distante da possibilidade de aplicação. A posição, no entanto, não deixa de ser lógica, e até moralmente, válida, já que não há status moral e demanda por direitos iguais aos nossos se o ser não for considerado uma pessoa.

Para Bortolotti (2007), um bom critério para a atribuição do status de pessoa seria a atividade intencional. Apesar de difícil definição, a autora acredita ser possível, através de rigorosa análise filosófica, encontrar meios de aplicar conceitos abstratos como este a padrões de comportamento específicos. Segundo a autora, a atividade intencional, ou a presença de preferências, seria um conceito mais abrangente que a "consciência de si mesmo".

As considerações a respeito de limites envolvendo a atividade cerebral e a consciência de si mesmo têm se mostrado bastante ricas e vão além da discussão do aborto, sendo relevantes também para as discussões a respeito de quando termina a vida de uma pessoa. Uma diferença importante entre os casos de eutanásia e os de aborto, segundo Belshaw (1997) é que as decisões sobre eutanásia são, tipicamente, decisões sobre e para o paciente, enquanto que no caso do aborto, são decisões sobre o feto, mas não para ele.

\subsection{Os Limites da Vida e a Responsabilidade da Decisão}

A discussão referente ao aborto está longe de ser acabada e merece ainda muita reflexão de todos os setores da sociedade. Os aspectos psicológicos, sociais, biológicos e morais da questão devem ser pesados com muito cuidado para que as decisões reprodutivas, tanto no âmbito individual como no legal, sejam tomadas visando à saúde e ao bem-estar da mulher sem desrespeitar o status moral de outros indivíduos. Nesse sentido, a Filosofia tem muito a contribuir com os aspectos político-legais relacionados ao aborto. 
A validade de cada limite comumente definido como possível para a terminação da gravidez deve ser analisada tendo em mente principalmente os conceitos de status moral e pessoa humana, além das conseqüências sociais e psicológicas do ato. A ideia de indivíduo parece ser importante para um melhor entendimento das relações na gestação, mas não pode ser confundida com a ideia de pessoa e nem ser definitiva para estabelecimento de um critério de presença de status moral. Afinal, o status de pessoa exige e supõe individualidade (ROSADO-NUNES, 2006), mas o contrário não é necessariamente verdadeiro.

Algumas ideias defendidas em relação ao aborto ainda parecem comprometidas com uma visão essencialista do ser humano, o que é discutível, principalmente à luz do conceito de "espécie como indivíduo" de Sober (1996). Talvez não a espécie humana, mas sim a ideia de "pessoa humana" faça mais sentido em uma perspectiva essencialista.

Espera-se que, à medida que identificamos e exploramos melhor todos os aspectos morais, sociais, psicológicos e biológicos relevantes à questão do aborto, mais próximos nos tornemos de um consenso ético. Mesmo assim, persiste a dúvida sobre a existência de uma realidade moral independente e o debate sobre a extensão da responsabilidade humana com a vida.

\section{O Estudo da Argumentação, Questões Sociocientíficas e Valores}

Conforme exposto anteriormente, o processo de negociação das questões sociocientíficas, por estas representarem problemas abertos e discutíveis, é chamado raciocínio informal (SADLER \& ZEIDLER, 2005). Os indivíduos podem expressar raciocínio informal através de argumentação dialógica (DRIVER, NEWTON \& OSBORNE, 2000), que tem se mostrado a melhor maneira de acessar tal raciocínio. Enquanto o raciocínio informal se refere aos processos cognitivos e afetivos envolvidos na negociação de questões complexas e à formação ou adoção de uma posição, a argumentação se refere à expressão verbal ou escrita desse raciocínio. Maturana e Varela (2007) explicam que os comportamentos aos quais temos acesso - no caso, o argumento - não devem ser confundidos com a dinâmica de relações internas que ocorrem em um sistema - aqui representadas pela formação de posições e o raciocínio 
informal. Apesar de não constituírem o mesmo conceito, argumentação e raciocínio informal geralmente são tomados, na prática, como similares, pois é muito difícil distingui-los empiricamente (SADLER \& ZEIDLER, 2005).

A argumentação tem ganhado renovada proeminência como um tema e uma abordagem para experiências de classe, assim como foco para pesquisa em educação. Em uma sala de aula com prática de argumentação, os aprendizes não apenas aprendem sobre ciência ou executam atividades relacionadas aos conceitos aprendidos, mas se tornam mais amplamente enculturados na Ciência e se apropriam de práticas científicas como parte de suas próprias identidades (SADLER \& FOWLER, 2006).

A perspectiva que contempla a aprendizagem de ciências como argumentação foi proposta por Deanna Kuhn (1993) e elaborada por outros autores como Driver et al. (2000). Segundo a autora, a Ciência apresenta-se intrinsecamente ligada à controvérsia e à argumentação. Afinal, o processo de investigação, busca de evidências, elaboração e apresentação de teorias - típico da forma como o conhecimento científico é construído assemelha-se a um processo argumentativo. Assim, não apenas as teorias, como também os fatos da Ciência tornam-se construções argumentativas que devem ser consideradas na arena do debate público. Para isso, cada cientista deve analisar as evidências e suas relações com as teorias como uma forma de argumento para a comunidade científica em defesa da sua visão. Tal processo de análise do argumento é, em forma interiorizada, uma importante parte do que ocorre no pensamento privado do cientista individual. Cientistas são bem conscientes de que argumentos explicitamente justificados são necessários para convencer a comunidade científica, e eles se tornam acostumados a pensar em tais termos.

Ainda de acordo com Kuhn (1993), o conceito de educação em ciências como forma de pensamento e argumento é muito promissor, face à crescente complexidade técnica, especialização e rápida evolução do conhecimento científico, que tendem a tornar insatisfatórios e difíceis o domínio e o ensino de qualquer área científica. A autora defende que a Ciência não precisa mais ser tratada como uma acumulação de afirmações, desconectadas do pensamento humano que lhes deu origem - formato que dificulta o trabalho do professor, já que tais afirmações se colocam de forma desconectada de seu próprio pensamento.

Nesse sentido, ao invés de simplesmente tentar relacionar o conteúdo da Ciência com fenômenos do cotidiano dos estudantes, os professores se beneficiariam ao tentar conectar os processos da Ciência aos processos de pensamento que as pessoas utilizam. 
Essas formas de pensamento podem ser rigorosamente definidas dentro do contexto fornecido pela estrutura do argumento. $\mathrm{O}$ ato de pensar, no sentido de argumentar, ou pensamento argumentativo, está implicado em todas as crenças que as pessoas têm, os julgamentos que elas fazem e as conclusões às quais elas chegam (KUHN, 1993).

Por argumentação se entende a capacidade de relacionar dados e conclusões, de avaliar enunciados teóricos à luz dos dados empíricos ou procedentes de outras fontes (JIMÉNEZ ALEIXANDRE \& DÍAZ de BUSTMANTE, 2003). Segundo Sadler \& Fowler (2006), argumentação circunscreve as práticas discursivas da Ciência e inclui a articulação e justificação de afirmações, a contemplação de contraposições e evidência, além da negociação social de dados e teorias. O raciocínio argumentativo é relevante para o ensino de ciências, já que um dos fins da investigação científica é a geração e justificação de enunciados e ações encaminhados à compreensão da natureza, razão pela qual o ensino de ciências deveria dar a oportunidade de desenvolver, entre outras, a capacidade de raciocinar e argumentar (JIMÉNEZ ALEIXANDRE \& DÍAZ de BUSTAMANTE, 2003).

Segundo Driver et al. (2000), para fornecer uma educação científica adequada para os jovens, é necessário reconceptualizar as práticas de ensino de ciências, de modo a retratar o conhecimento científico como socialmente construído. Para atingir tal objetivo, nós devemos dar mais atenção às práticas discursivas, principalmente à argumentação. A capacidade de apresentar argumentos coerentes e de avaliar outros, principalmente aqueles que são veiculados pela mídia, é importante, considerando que os estudantes devem entender as bases do conhecimento com o qual são confrontados. Além disso, em nossa sociedade contemporânea e democrática, é essencial que os jovens recebam uma educação que os ajude a construir e analisar argumentos relativos às aplicações sociais e implicações éticas da Ciência.

Vários autores defendem a utilização do argumento em diferentes níveis e para diversas finalidades no ensino de ciências: como uma forma de melhorar o entendimento dos conteúdos conceituais relacionados, para promover uma melhor compreensão da epistemologia da Ciência, para desenvolver habilidades investigativas, ou para melhorar a qualidade da tomada de decisões em questões sociocientíficas (GEDDIS, 1991; SOLOMON, 1992; RATCLIFFE, 1996; DRIVER et al., 2000; ZOHAR \& NEMET, 2001; WALKER \& ZEIDLER, 2007).

O campo de estudos da argumentação foi estabelecido quando uma distinção importante foi feita entre o estudo da lógica, relacionado às regras para a produção de 
inferências corretas a partir de premissas dadas, e o estudo de como as pessoas realmente raciocinam - das premissas às conclusões - em situações específicas. Enquanto a lógica é vista como uma disciplina acadêmica que apresenta regras descontextualizadas para relacionar premissas a conclusões, a argumentação é uma prática humana que é situada em contextos sociais específicos. A partir desta perspectiva, o argumento pode ser visto como uma atividade individual - através do pensamento e da escrita - ou como uma atividade social, ocorrendo em um grupo - um ato social negociado dentro de uma comunidade específica (DRIVER et al., 2000).

Nos últimos anos, diversos autores elaboraram, de diferentes pontos de vista, modelos sobre os elementos que constituem uma argumentação, as inter-relações que devem ser estabelecidas necessariamente entre tais elementos para que ela seja válida e que tipos de sequências são característicos da argumentação (SARDÀ JORGE \& SANMARTÍ PUIG, 2000).

Dentre os principais trabalhos sobre modelos de argumentação, destaca-se o de Van Dijk (1978), que parte do princípio que o que define um texto argumentativo é sua finalidade, ou seja, convencer outra pessoa. Segundo o modelo de Van Dijk, os elementos fundamentais do argumento são a justificação e a conclusão. A justificação se constrói a partir de um marco geral, no contexto do qual as circunstâncias que se utilizam para justificar as conclusões tomam sentido. Tais circunstâncias se referem a fatos e a condições iniciais ou pontos de partida que o emissor considera que são compartilhados pelo receptor. Para o autor são importantes também os conceitos de macroestrutura, supraestrutura e microestrutura. A macroestrutura da argumentação se relaciona com o fato de que a sequência de orações estabelecida deve estar destinada a justificar uma tese, com a finalidade e intencionalidade de convencer alguém. A supraestrutura permite analisar os conceitos sobre um determinado tema e suas relações, assim como os conectores e outros elementos gramaticais que tornem explícitas tais relações. Já o estudo da microestrutura do texto argumentativo se aproxima do uso de diferentes tipos de orações e suas conjunções, atentando para a maneira como elas explicitam as relações lógico-argumentativas (SARDÀ JORGE \& SANMARTÍ PUIG, 2000).

Outro importante autor que se ocupa do estudo do argumento é o lingüista JeanMichel Adam (1992), que trata do assunto em um capítulo de seu livro "Les textes: types et prototypes". O trabalho do autor francês sobre argumentação se baseia no modelo de Toulmin (2003) - explicado mais adiante -, mas admite maior flexibilidade 
na análise da estrutura do texto, já que permite, por exemplo, "conclusões concessivas", quando um determinado dado é seguido por uma conclusão que não obedece à regra de inferência implícita, ou seja, a conclusão difere do que seria esperado normalmente. Tomando como exemplo a frase: "Maria é uma criança, mas não gosta de chocolate.", temos que "Maria é uma criança" é um dado, enquanto "mas não gosta de chocolate" é uma conclusão concessiva, já que contraria a regra de inferência implícita que seria algo do tipo "crianças gostam de chocolate". O modelo argumentativo de Adam abrange esse tipo de conclusão, diferentemente dos modelos de alguns outros autores.

Adam admite também que uma conclusão sirva como dado para um outro argumento, em sequências argumentativas encadeadas. Além disso, o autor estabelece o conceito de "heterogeneidade de tipo", segundo o qual os textos podem estar estruturados em diferentes "sequências de base", havendo, geralmente, um tipo de sequência dominante e outra dominada, como, por exemplo, no caso de um texto narrativo que apresenta uma estrutura argumentativa a serviço da sequência narrativa. $O$ autor utiliza como exemplo de tal conceito um conto do escritor Hans C. Andersen que, por sua própria natureza, é uma sequência narrativa, mas em cuja estrutura podemos identificar elementos típicos da argumentação, como dados e conclusões, organizados de forma subordinada à narração. Diversas outras combinações desse tipo também são possíveis.

Outra elucidação importante feita por Adam a respeito da estrutura argumentativa é a existência de dois modos particulares de composição das proposições, seja segundo uma "ordem progressiva": dados - [inferência] $\rightarrow$ conclusão, ou segundo uma "ordem regressiva": conclusão +... [inferência] - dados. Na ordem progressiva [d ENTÃO $\rightarrow$ c], o enunciado lingüístico é paralelo ao movimento do raciocínio, já que a consequiência aparece depois das razões. Na ordem regressiva [c +... PORQUE - d], a linearidade do enunciado lingüístico é inversa ao movimento argumentativo, já que se justifica uma afirmação que precede textualmente a premissa. Enquanto a ordem progressiva visa a concluir, a ordem regressiva é mais utilizada como prova ou explicação. Observa-se que, no discurso oral, a ordem regressiva parece ser bem mais comum que a progressiva.

Em termos gerais, uma das maiores contribuições do autor à teoria do argumento se refere à sua visão flexível do texto, contrária à tentativa de enquadrá-lo nos limites de uma definição estrita. Nesse sentido, este trabalho faz uso das ideias de Adam, especificamente no que se refere à aceitação de argumentos em ordem regressiva e à 
possibilidade de os argumentos surgirem em sequências encadeadas, com partes de um argumento originando um argumento seguinte.

Provavelmente o autor mais importante da área é Toulmin (2003) que, com seu livro "Os Usos do Argumento", liderou uma ruptura com o foco tradicional da lógica formal, partindo para o estudo das maneiras como as pessoas argumentam em situações naturais. Autores mais recentes reconhecem também que a argumentação, principalmente na sala de aula, não se rege exatamente pelos mesmos padrões que a argumentação em filosofia, já que não segue necessariamente as regras da lógica, mas representa uma prática humana, individual ou social (JIMÉNEZ ALEIXANDRE \& DÍAZ de BUSTAMANTE, 2003; DRIVER et al., 2000).

Baseado em sua análise de argumentos em uma variedade de contextos, incluindo questões de direito e argumentos em ciência, Toulmin apresentou um modelo que descreve os elementos constitutivos da argumentação e representa as relações funcionais entre eles (DRIVER et al., 2000; TOULMIN, 2003).

O primeiro elemento de um argumento segundo o padrão de Toulmin (2003) é o "dado" (D). Dados são os fatos aos quais recorremos como fundamentos para uma determinada alegação, chamada, por sua vez, conclusão (C). Assim, exposta determinada alegação (C), necessita-se dos dados (D) para que tal proposição seja justificada. Pode ser necessário também que o argumentador explique de que forma o raciocínio pode levar dos dados à conclusão. Nesse caso, uma garantia (W - de "warrant", em inglês) é o elemento com o poder de mostrar que, tomando-se aqueles dados como ponto de partida, é apropriado e legítimo passar dos dados à alegação ou conclusão apresentada.

Tomemos como exemplo a seguinte frase: "O feto é um ser vivo, pois ele respira.". Nesse caso, temos como dado (D) "pois ele respira" e como conclusão (C) "O feto é um ser vivo". A garantia (W) que poderia ligar os dois elementos seria algo do tipo "a respiração é um fenômeno exclusivo dos seres vivos". O próprio Toulmin reconhece que a distinção entre dados e garantias pode ser confusa. No entanto, afirma que, em algumas situações, é possível distinguir entre duas funções lógicas diferentes, pois cada uma possui características peculiares. Uma forma de distinguir pode ser baseando-se no fato de que as garantias são de natureza mais universal que os dados, que geralmente representam constatações particulares. Por essa razão, as garantias têm de ser estabelecidas de modo muito diferente dos fatos que apresentamos como dados. 
Outra distinção é que se recorre a dados de forma explícita, enquanto que as garantias muitas vezes estão implícitas.

Ocorre também que as garantias muitas vezes podem ser desafiadas, e o padrão de argumento de Toulmin considera um outro elemento para dar conta deste problema. Assim, o apoio (B - de "backing”) representa os avais que estão por trás das garantias, sem os quais nem as próprias garantias teriam autoridade ou vigência. No exemplo citado, poderíamos pensar no apoio como todos os trabalhos científicos que estabeleceram a respiração como um fenômeno biológico.

Dois outros elementos devem ser também citados para completar o modelo de argumento de Toulmin. São eles os qualificadores (Q) e os refutadores (R). Qualificadores indicam a força conferida pela garantia. Assim, aproveitando o mesmo exemplo, uma pessoa que apresentasse problemas conceituais com o fenômeno da respiração, e não estivesse muito certa da relação entre tal fenômeno e a existência de vida, poderia dizer: "Dado que o feto respira, então, provavelmente, ele é um ser vivo". Aqui, a palavra "provavelmente" confere um certo grau de incerteza ao argumento, em função de uma garantia não muito forte. Se, de outra forma, a pessoa dissesse "O feto respira, então, com certeza, ele é um ser vivo.”, o qualificador (Q) “com certeza” surge com a função de indicar a maior força da garantia.

Por fim, o refutador $(\mathrm{R})$ é o elemento que indica circunstâncias nas quais se tem de deixar de lado a autoridade da garantia. Em outras palavras, o refutador estabelece quando a conclusão não é válida. Com o exemplo acima é um tanto difícil pensar em uma condição que estabeleça a invalidação da garantia, mas podemos pensar em outro argumento, como: "Maria acordou bem disposta hoje, então, irá à palestra, a menos que chova." Neste argumento, temos o dado (D) "Maria acordou bem disposta hoje" que suporta a conclusão (C) "[Maria] irá à palestra hoje”, exceto em uma condição: "a menos que chova".

A exploração filosófica da argumentação por Toulmin (2003) teve profundos impactos no estudo e na abordagem da argumentação, particularmente com respeito ao ensino de ciências. O padrão de argumento de Toulmin tem servido como uma ferramenta analítica importante para muitos (provavelmente a maioria) dos estudos que procuram avaliar a qualidade dos argumentos oferecidos pelos estudantes em contextos científicos e sociocientíficos (JIMÉNEZ-ALEIXANDRE et al., 2000; OSBORNE et al., 2004; ZOHAR \& NEMET, 2002). 
Algumas limitações metodológicas do modelo estão relacionadas à distinção entre dados, garantias e apoios (ERDURAN et al, 2004). Alguns autores têm resolvido esse problema unificando as categorias mais problemáticas (dados, apoios e garantias considerados como bases - "grounds") e focando principalmente na emergência de refutadores. O problema é que isso torna o modelo utilizável apenas em discussões em grupo (SADLER \& FOWLER, 2006).

Segundo Driver et al. (2000), o modelo de Toulmin é, de certa forma, limitado, pois, apesar de poder ser usado para acessar a estrutura dos argumentos, ele não leva a julgamentos sobre sua correção. Como o próprio autor haveria assinalado, se julgamentos sobre a correção dos argumentos devem ser feitos, é necessário incorporar o conhecimento do assunto relacionado. Afinal, os apoios (B) dos argumentos são específicos para cada área do conhecimento. Esse tipo de questão será discutido novamente mais adiante, quando analisarmos a utilização de conceitos pelos participantes da discussão.

Apesar das críticas, a própria autora constata que o modelo é bastante influente ainda nos dias de hoje e tem sido usado por um número cada vez maior de pesquisadores em ensino de ciências para analisar os argumentos dos estudantes (DRIVER et al., 2000). Algumas vezes com adaptações ao tipo de estudo realizado, o modelo de Toulmin tem sido um método bastante comum para identificar e quantificar as características dos argumentos de alunos relacionados a questões científicas e sociocientíficas (JIMÉNEZ-ALEIXANDRE et al, 2000, WALKER \& ZEIDLER, 2007).

O trabalho de Patronis et al. (1999) é um exemplo dos que utilizam o padrão de argumento de Toulmin para tratar dados referentes a questões sociocientíficas. Os autores analisaram a dinâmica do aparecimento de argumentos e o seu desenvolvimento durante a discussão. Duas dimensões foram identificadas para os argumentos, que podiam ser classificados quanto ao processo e quanto à sua natureza. Em relação ao processo, os argumentos eram: de defesa ou ataque, estáveis (quando apareciam sempre da mesma forma) ou inventados (quando surgiam novos na discussão). Quanto à natureza, os argumentos se mostravam qualitativos, semi-qualitativos ou quantitativos, já que se referiam a deliberações dos alunos discutindo a construção de uma ponte, em um trabalho envolvendo matemática e ciências.

Muitos outros trabalhos fazem uso do modelo de argumentação de Toulmin, principalmente para analisar a qualidade dos argumentos dos alunos, característica que é 
avaliada geralmente pela presença ou ausência de determinados elementos do padrão na fala ou na escrita dos estudantes (DRIVER et al., 2000; OSBORNE et al., 2004; WATSON et al., 2004; von AUFSCHNAITER et al., 2008; ZOHAR \& NEMET, 2002).

Uma abordagem diferente do modelo de argumento de Toulmin é utilizada por Kolsto (2006), que não procura analisar a qualidade, mas sim os padrões de argumentos e valores utilizados por alunos ao discutirem uma questão sociocientífica, abordagem que é compartilhada pelos objetivos deste trabalho.

Nesse estudo, realizado na Noruega, os estudantes respondiam a questões referentes ao problema da construção de linhas de força e a possibilidade de aumento dos casos de leucemia infantil. Kolsto chamou a questão sociocientífica tema de seu trabalho de "risk-focused", pois, em função da natureza do problema, os padrões emergentes das respostas dos estudantes geralmente focavam em suas percepções do risco e na importância de outros fatores em relação a esse mesmo risco.

Nesse sentido, o presente trabalho se distingue do artigo de Kolsto e de outros trabalhos com questões sociocientíficas, já que, no aborto, o dado a ser analisado não é um dado relativo, como o risco de desenvolver leucemia por causa das linhas de energia. O que é relativo, no caso do aborto, é o reconhecimento sobre a presença ou a ausência de status moral de pessoa no zigoto, no embrião ou ainda no feto. Pelo menos nas definições e crenças sobre o início da vida, não é a ocorrência de um fenômeno ou uma relação de causalidade que é incerta, mas sim um status.

Em Kolsto (2006), cinco padrões de argumentos foram identificados. Para distinguir tais tipos de argumentos, Kolsto (2006) fez uso de uma versão simplificada do modelo de Toulmin. Considerando que a estrutura básica de um argumento requer a presença de dado (D), conclusão (C) e garantia (W), a fala dos estudantes foi classificada de acordo com tais parâmetros para identificar argumentos e valores. Cada tipo de argumento nesse trabalho se mostrava associado a um determinado valor, definido como uma ideia à qual uma pessoa apela como critérios ou garantias. Dessa forma, os valores são exatamente as garantias que os estudantes utilizavam para conferir autoridade aos seus argumentos sobre a questão sociocientífica.

Os valores associados aos argumentos, no trabalho de Kolsto (2006), foram os seguintes:

- argumento do "risco relativo" - valor: custo-benefício

- argumento de "precaução" - valor: princípio de precaução 
- argumento "decisão impossível” - valor: bem-estar econômico e saúde

- argumento do "pequeno risco" - valor: riscos são parte natural da vida

- argumento "prós e contras" - valor: bem-estar das pessoas afetadas

No presente trabalho, uma análise semelhante à de Kolsto foi aplicada aos dados referentes à discussão sobre o aborto. Assim, após a identificação dos argumentos de acordo com o modelo de Toulmin (2003), foram inferidos os valores que estão por trás das garantias implícitas ou explícitas dos estudantes.

O trabalho de Kolsto (2006), por sua análise dos valores como equivalentes às garantias para os argumentos, assim como o trabalho de Sadler \& Zeidler (2004), que identifica os padrões morais racionalista deontológico, racionalista consequencialista, emotivo e intuitivo, representam os principais referenciais deste trabalho, que faz uso de tais abordagens no tratamento de dados relativos a uma questão sociocientífica ainda pouco explorada: o aborto.

\section{Objetivos}

Tendo em vista a importância dada às questões sociocientíficas pela literatura da área de ensino de ciências, as abordagens utilizadas para o estudo da formação de julgamentos morais e a escassez de trabalhos nessa área no Brasil e com estudantes de ensino fundamental, este trabalho pretende:

- Identificar os padrões morais utilizados por alunos de ensino fundamental ao abordarem questões sociocientíficas relacionadas à problemática do aborto;

- Identificar, através da análise da estrutura dos argumentos, os valores que fundamentam as posições adotadas pelos mesmos alunos;

- Identificar, no contexto da análise de argumentos segundo o modelo proposto por Toulmin (2003), a função de tais valores nos argumentos produzidos pelos alunos;

- Buscar e discutir relações entre valores e padrões morais no contexto da discussão sobre o aborto;

- Identificar quais conceitos científicos os alunos trazem à discussão sobre o aborto, e qual o papel de tais conceitos nos argumentos utilizados;

- Buscar e discutir relações entre os conceitos científicos e as categorias de padrões morais. 


\section{Metodologia}

Este trabalho possui um foco inicialmente descritivo em relação aos padrões que podem ser derivados dos argumentos que os alunos empregam ao discutir questões sociocientíficas. Também são propostas relações entre as categorias identificadas no discurso dos estudantes.

\subsection{Coleta dos dados}

O material aqui analisado refere-se a uma atividade realizada em novembro de 2007 em uma sala de aula de oitavo ano do ensino fundamental de um colégio particular de São Paulo. Enquanto muitos dos estudos sobre ideias prévias são realizados sobre amostras amplas com provas escritas ou entrevistas em momentos determinados, os trabalhos sobre o discurso da aula geralmente são estudos sobre amostras reduzidas, como é o caso. Estudos qualitativos realizados no ambiente da sala de aula são interessantes para a pesquisa em educação, já que as classes, como sistemas muito complexos, não admitem bem o isolamento de um de seus componentes para ser estudado de forma independente (JIMÉNEZ ALEIXANDRE \& DÍAZ BUSTAMANTE, 2003).

A maioria dos alunos participantes representa parte da classe média e da classe média alta da cidade de São Paulo, já que a escola se situa em um bairro onde as famílias têm rendimentos médios relativamente altos $(49,05 \%$ dos domicílios com renda familiar igual ou superior a 25 salários-mínimos, com base no censo de 2000, segundo a Secretaria de Economia e Planejamento do Estado de São Paulo, 2009), perto da região da Avenida Paulista. Suas idades variavam de 12 a 14 anos, faixa etária não muito comum nas pesquisas com questões controversas, mas trabalhos anteriores já haviam identificado a necessidade de investigar raciocínio informal sociocientífico com participantes de várias idades (SADLER, 2004; YANG \& ANDERSON, 2003; SADLER \& ZEIDLER, 2005).

O presente trabalho se baseia em dados oriundos da interação social (SOLOMON, 1992). Trata-se da análise de uma discussão em grupos sobre questões relativas ao problema do aborto. 
Conforme a sequência didática exposta abaixo, os alunos foram dispostos em grupos para discutir as questões propostas pelo professor, que é o próprio pesquisador e autor deste trabalho. Para fornecer maior profundidade no acesso às ideias dos alunos, cada item pedia que os participantes justificassem suas respostas (BELL \& LEDERMAN, 2003; WATSON et al., 2004). As questões como foram entregues aos alunos podem ser visualizadas no anexo I.

Neste trabalho, as discussões de cinco grupos foram gravadas com a utilização de gravadores do tipo mp3 players, que, durante a atividade, ficaram em poder dos próprios alunos. Embora dados de discussões em grupo sejam bem mais difíceis de avaliar do que entrevistas, eles fornecem evidências diretas dos processos de persuasão e argumento e são o primeiro estágio na construção social e pessoal do entendimento (SOLOMON, 1992). No dia da atividade, havia ainda mais um grupo, formado por alunos que não queriam ser gravados e que, portanto, não integram os dados. Os alunos gravados foram anteriormente consultados, assim como os pais, que deram seu consentimento por escrito, sabendo que os dados seriam utilizados para análise e pesquisa.

Após o término da discussão, os próprios alunos desligaram os gravadores e os entregaram para o professor. O fato de os alunos terem o controle dos gravadores durante a discussão não parece ter atrapalhado a atividade. Pelo contrário, é visível nas transcrições (anexo III) que os alunos parecem bem à vontade com a presença e a necessidade de manejo dos aparelhos. Isso talvez se deva ao fato de tais alunos já terem sido gravados anteriormente, pelo mesmo professor, em outra atividade de discussão em grupos no mesmo ano. Nessa outra ocasião, os alunos também tinham o controle dos gravadores, e um dos grupos obteve uma gravação de qualidade superior por terem decidido aproximar o aparelho dos falantes durante a atividade. Em virtude dessa constatação, na discussão sobre o aborto, o professor combinou com todos os alunos a adoção do mesmo método, ou seja, de aproximação do aparelho aos falantes, o que garantiu registros mais inteligíveis sem prejudicar a dinâmica dos grupos, que não demonstraram ansiedade com relação ao procedimento.

Segundo Solomon (1992), os estudantes muitas vezes enxergam o processo de gravação de seu trabalho como um sinal de que suas discussões estão sendo valorizadas. Dessa forma, a gravação e a manipulação dos gravadores poderiam ser considerados como possuindo um impacto positivo na motivação e na auto-estima dos estudantes. Trabalhos que visem a investigar as vantagens ou desvantagens de tais especificidades 
metodológicas podem trazer resultados interessantes e frutíferos para a pesquisa em educação.

Durante a gravação, os participantes também escreveram as respostas nas folhas de questões. Não foi requerido que cada participante entregasse uma folha com as respostas individuais, assim, foram obtidas algumas folhas respondidas individualmente e outras representativas do grupo todo. Neste trabalho, os grupos são identificados com as letras A, B, C, D e E. As respostas escritas desses cinco grupos foram aproveitadas neste trabalho e integradas aos dados oriundos da discussão oral, para conferir, aos mesmos, maior validade. Nos grupos A e C, apenas um aluno do grupo entregou a folha escrita. No grupo E, os alunos entregaram apenas a folha contendo as quatro primeiras questões, provavelmente por problemas com o tempo. As respostas escritas dos estudantes se encontram no anexo II.

A atividade durou o tempo de duas aulas, ou seja, dois períodos de 50 minutos. Nos primeiros 50 minutos, os alunos assistiram a trechos representativos do filme "O Segredo de Vera Drake" - filme que aborda a questão problemática do aborto escolhidos pelo professor. O tempo restante foi utilizado para organizar e realizar a discussão em grupos. Nas transcrições, podemos observar que os períodos de gravação não são necessariamente contínuos dentro de cada grupo, em função do diferente manejo que cada grupo fazia dos gravadores, o que, no entanto, não prejudicou, de forma alguma, a obtenção e análise dos dados.

Não foram feitos registros de vídeo das interações, mas apenas do áudio, por questões de ordem prática e por não haver interesse, neste estudo, em analisar aspectos multimodais da discussão. As discussões de cada grupo foram cuidadosamente transcritas para que a fase seguinte do tratamento dos dados pudesse ter início. As transcrições das falas dos alunos podem ser observadas, na íntegra, no anexo III.

\subsubsection{Contexto e Sequência Didática}

Conforme exposto acima, este trabalho está centrado na análise de uma atividade de discussão em pequenos grupos realizada com alunos de ensino fundamental lidando com questões propostas sobre o problema aborto. Tal atividade foi estruturada tendo em vista que os alunos podem facilmente sair da tarefa se o tópico não é bem focado, se demora muito tempo ou se os objetivos não são claros (ZEIDLER et al., 2005). 
O conteúdo estudado pelos alunos do oitavo ano na disciplina de ciências no bimestre dentro do qual a atividade foi realizada contempla vários aspectos da reprodução humana, como aparelho reprodutor masculino, aparelho reprodutor feminino, fecundação, gravidez, métodos anticoncepcionais, doenças sexualmente transmissíveis e Leis de Mendel. A questão sociocientífica do aborto era, além de um tema relacionado ao conteúdo estudado, um assunto que os alunos demandavam discutir, pois, durante as aulas, faziam perguntas sobre o tema e levantavam o debate frequentemente.

Sequências didáticas são, segundo Coll \& Onrubia (1998), processos completos de ensino e aprendizagem relacionados com objetivos, conteúdos e tarefas determinadas que apresentam um início, um desenvolvimento e um final claramente reconhecíveis. A atividade aqui descrita pode ser considerada uma sequência didática, no entanto, neste trabalho, ela não é a unidade de análise, já que apenas os elementos discursivos da interação dos alunos durante a fase de discussão em grupos é analisada.

A sequência didática foi organizada pelo professor - que é também o pesquisador-autor deste trabalho - da seguinte forma: exibição de partes de um filme contextualizando a questão, formação de pequenos grupos, discussão de questões propostas pelo professor (anexo I) e escrita das respostas individuais ou do grupo.

De início, os alunos assistiram a trechos do filme "O Segredo de Vera Drake", que explora, de forma interessante, a questão do aborto em sua complexidade. A apresentação do filme visava a estabelecer um ponto referencial, de modo paralelo ao conteúdo estudado no bimestre, para o início da discussão. Segundo Solomon (1992), os estudantes necessitam apenas de uma familiaridade simples com os termos científicos usados para permitir uma discussão valiosa no que diz respeito à construção e troca de visões morais e civis.

Tanto a apresentação do filme quanto a discussão foram realizados em uma sala que não é a sala onde os alunos costumavam ter aulas, já que o aparelho de projeção se situava em uma sala específica. A sala também era maior do que as salas onde os alunos comumente assistiam às aulas, o que permitiu que os grupos se distribuíssem com uma distância mais adequada um do outro, o que foi importante para reduzir os ruídos na gravação e também para garantir uma maior qualidade de discussão entre os alunos dos grupos.

Após assistirem a trechos do filme, os alunos se organizaram em grupos de 3 a 5 integrantes para discutirem as oito questões sobre o aborto entregues em duas folhas 
pelo professor (anexo I). Os grupos foram escolhidos pelos próprios alunos, que deveriam discutir coletivamente cada questão e depois deveriam escrever as decisões do grupo - ou as individuais - na folha.

Este segmento da sequência didática, ou seja, o momento em que os alunos discutiam as questões em grupos, corresponde à unidade básica de registro, análise e interpretação deste trabalho.

\subsection{2. “O Segredo de Vera Drake” e a Contextualização do Aborto}

O filme assistido pelos alunos, dirigido por Mike Leigh e protagonizado por Imelda Staunton, se passa na Inglaterra dos anos 50 (época em que a prática de aborto representava um crime no país) e conta a história de Vera Drake, uma mulher pobre e generosa que, às escondidas, realiza abortos para moças que julga estar ajudando. Vera também é uma zelosa esposa e mãe de dois filhos, além de cuidar da mãe doente e trabalhar como empregada doméstica em casas mais abastadas.

Vera Drake realizava os abortos utilizando métodos um tanto rudimentares: com o auxílio de uma bomba de sucção, introduzia na vagina das moças uma mistura de água, desinfetante e sabão, o que nem sempre resultava em abortos seguros para a saúde das mulheres submetidas ao procedimento. O filme aborda a questão controversa em vários aspectos e sob a ótica de diferentes personagens, representativos de diferentes grupos sociais. Dessa forma, ele se torna uma interessante ferramenta para incitar discussão na sala de aula, já que também traz à tona o problema do aborto nos casos de estupro, os impactos fisiológicos e psicológicos da interrupção da gravidez, o aspecto legal e as diferenças de acesso a condições clínicas mais seguras dependendo da classe econômica.

\subsubsection{Trabalhos em Grupo: Oportunidades para Argumentação}

Trabalhos em grupo parecem oferecer grandes oportunidades para argumentação, e quando bem orientados são bastante referenciados e estimulados na literatura da área de ensino de ciências. De acordo com Kuhn (1993), o diálogo social oferece uma forma de externalizar aquelas estratégias de pensamento internas que nós gostaríamos de estimular nos indivíduos. Os trabalhos em grupo fornecem raras e consideráveis oportunidades de promover apreciação das normas do discurso científico. 
Segundo Solomon (1992), se o objetivo final da educação em ciências é produzir uma geração informada de novos cidadãos que podem participar na tomada de decisões democráticas, então poderíamos certamente argumentar que as habilidades da discussão em pequenos grupos são de enorme importância educacional.

A oportunidade de argumentar oferecida por esse tipo de atividade é importante também para que os alunos possam adquirir competência crítica em decisões e diplomacia, principalmente para desenvolver e discutir modelos científicos, o que deve levar a uma cidadania crítica (PATRONIS et al., 1999).

A prática de discussões sociocientíficas na sala de aula caminha no mesmo sentido dos objetivos do ensino de ciências ligados à cidadania. Segundo Zeidler et al. (2005), de modo a desenvolver cidadãos alfabetizados cientificamente, a comunidade de ensino de ciências deve ir além das ideias e práticas CTS passadas, de modo a envolver os estudantes com os tipos de questões e problemas que desenvolvem tanto o intelecto como o senso de caráter.

\subsection{Análise dos dados}

Neste trabalho foi decidido usar uma abordagem qualitativa, já que a questão de pesquisa é de natureza exploratória e implica um foco nas ideias dos alunos e na categorização de tais ideias. Tal abordagem está de acordo com autores como Kolsto, (2001) e a maioria dos autores da área de questões sociocientíficas. A unidade de análise típica deste trabalho é o argumento, como definido por Toulmin (2003). Por isso, as transcrições das falas dos alunos foram triadas para a identificação de argumentos contendo, pelo menos, dados - ou justificativas, já que, em uma discussão sociocientífica, dificilmente os "dados" de um argumento são empíricos - e conclusões, com garantias explícitas ou não. Quando as garantias não estavam explícitas na fala dos alunos, foram criadas garantias inferidas a partir dos elementos presentes para facilitar o posterior trabalho de identificação de valores. O processo de identificação de partes do argumento às vezes pode ser visto como um esforço para decifrar e interpretar dados que estão explícitos de modo a se acessar os implícitos (OSBORNE et al., 2004).

Cada fragmento de diálogos e discussões, qualquer que seja seu tamanho, foi considerado parte do mesmo argumento quando a conclusão era a mesma, e distinto quando se modificava (JIMÉNEZ ALEIXANDRE \& DÍAZ BUSTAMANTE, 2003). 
No caso abaixo, por exemplo, as meninas discutiam sobre uma garota fictícia que havia engravidado por acidente. As conclusões (marcadas aqui em negrito) das duas alunas são idênticas, e são fornecidos diferentes suportes ou dados (sublinhados) para tais conclusões. Como a conclusão é a mesma, consideramos aqui como um mesmo argumento com mais de um dado, mesmo que ocorram em turnos de fala e sujeitos distintos:

\section{Grupo D,}

C63: "Eu acho assim, que a Jane ela devia assumir a criança porque mesmo que foi uma coisa não prevista por ela... aconteceu, então agora ela assume, porque que nem a K. disse ela não foi obrigada a transar com ele... foi uma decisão conjunta... e eles sabiam dos riscos que poderia ter... depois... devia trancar a faculdade que nem a $\mathrm{L}$. disse e procurar um trabalho pra poder sustentar o filho... pedir ajudar pros pais se não conseguir..."

L64: "Olha eu acho que a C. tem toda razão, porque a Jane... tudo bem eles se preveniram... só que eles eram novos também não sabiam.... mas pô aconteceu... não foi desculpa, não foi estupro...”

As respostas escritas pelos alunos foram utilizadas para conferir maior validade às interpretações dos argumentos feitas pelo pesquisador. A forma de análise dos argumentos foi validada em discussões com o grupo de pesquisa.

Neste trabalho, uma aproximação do modelo de Toulmin (2003) à mais recente abordagem de Adam (1992) deve ser levada em consideração, já que aqui se reconhece a possibilidade de elementos de um argumento anterior servirem para a formação de um novo argumento, assim como a validade de argumentos em “ordem regressiva”, ou seja, nos casos em que se justifica uma afirmação que surge antes do dado no texto. A adição de tais considerações pretende tornar a análise dos dados mais flexível e compatível com a estrutura da argumentação oral - objeto de estudo da pesquisa aqui desenvolvida.

Falas de alunos contendo apenas asserções sem justificativas também foram identificadas e aparecem nas tabelas na posição de conclusões, por apresentarem funções similares a estas na interação. Para Osborne et al. (2004), elas são importantes por representarem o primeiro passo no sentido de iniciar o processo de estabelecimento de diferenças. Aqui, elas são extremamente importantes por representarem um dos padrões de raciocínio informal: a moral intuitiva, caracterizada pela ausência de 
justificativas racionais para determinada posição. $\mathrm{O}$ enunciado abaixo é um exemplo desse tipo de padrão moral:

Grupo D, B68: "Eu no caso dela, deveria abortar, eu ia abortar..."

Simultaneamente à localização dos argumentos, estes tiveram seus elementos identificados e separados em uma tabela, que será explicada em detalhes mais adiante. Apenas os dados das discussões das questões de números dois, cinco e oito não foram incorporados à tabela, em função de não serem muito representativos das ideias dos estudantes sobre o aborto, ou por serem questões de natureza bastante diferente das outras, o que torna sua inclusão uma dificuldade à análise. Após a classificação dos elementos dos argumentos, foram identificados os padrões morais e os valores para cada argumento. Isso foi feito tomando como base as descrições de categorias de padrão moral nos trabalhos de Sadler \& Zeidler $(2004,2005)$ e através de uma análise cuidadosa das garantias que serviam de suporte às conclusões dos argumentos. Visando a conferir maior validade ao estudo, a forma de análise dos argumentos para atribuição de padrões morais e valores também foi discutida no grupo de pesquisa.

Por fim, foi feita uma análise dos conceitos científicos que surgiram nos argumentos dos alunos. Não foram considerados aqueles conceitos que já apareciam nas questões, pois eles não necessariamente representariam conceitos buscados ativamente pelos alunos, podendo ser apenas repetições das partes das questões. Os conceitos utilizados na discussão do aborto foram identificados e tiveram suas posições nos argumentos analisadas, segundo o modelo de Toulmin (2003). As relações entre os conceitos científicos e os padrões morais, além de sua importância nos assuntos sociocientíficos também são discutidos.

Da mesma forma que para os conceitos científicos, os valores também foram analisados quanto à correlação com padrões morais e funções que eles exerciam naqueles argumentos que possuíam conceitos científicos. 


\subsection{Apresentação dos dados}

Os dados neste trabalho estão organizados em quatro formas diferentes: transcrições, respostas escritas, tabelas e gráficos.

As transcrições e respostas escritas serviram de base para a elaboração de cinco tabelas - disponíveis no anexo IV -, sendo cada uma representativa da discussão de um grupo. A partir das tabelas do anexo IV, que contêm os argumentos utilizados na discussão, foram elaboradas as outras tabelas e os gráficos presentes no trabalho.

As tabelas foram montadas com os diferentes argumentos e asserções sem justificativas dispostos nas linhas e as partes dos argumentos dispostas nas colunas. Nas linhas também podem ser localizados os códigos identificadores dos alunos (letras maiúsculas) e o número do enunciado do qual aquele argumento foi retirado. Os alunos são marcados com a letra "c" caso aquele aluno não tenha produzido o argumento em questão, mas tenha manifestado sua concordância com ele; e são marcados com a letra "e" caso aquele argumento seja proveniente da folha de respostas escritas, e não da discussão oral. Junto aos códigos dos alunos, também podem aparecer asteriscos, quando o argumento é derivado da refutação de um argumento anterior.

Muitos argumentos aparecem na tabela como sendo produzidos por muitos alunos, o que realmente aconteceu, em casos onde várias falas continham conclusões semanticamente idênticas ou simplesmente quando os alunos concluem a mesma coisa. Ocorreram também casos de vários alunos utilizando as mesmas justificativas. São consideradas também as asserções sem justificativas, já que aqui elas representam o tipo de raciocínio informal intuitivo, além de possuírem considerável impacto na interação.

No exemplo seguinte, na figura 1, estão reproduzidos, na tabela, argumentos e asserções do grupo D retirados das seguintes falas:

L5: “... o aborto não vai parar... mesmo clandestino ou não... acho que por meio lado, certo lado, o B. tá certo, porque se fosse, como é que chama... legislado...se não fosse proibido o aborto no Brasil, seria muito mais higiênico, ia sobreviver muito mais pessoas e não ia existir tantas coisas clandestinas..."

L8: “... o aborto tipo assim, ele podia ser sei lá, o aborto é proibido a não ser duas questões, é... o estupro ou sei lá... tá em risco de vida ou morte a mãe da crianca, isso pode ser relacionado ao aborto..." 
B3: “... se o caso da mulher também estiver em risco a vida dela... ou em caso de estupro ou alguma doenca assim né, problema mental essas coisas... que ela não pôde controlar nem nada..."

C171: "Eu acho assim, tudo bem... em caso de gravidez com o parto com risco de vida tudo bem pra mãe... doente mental, como a B disse..."

\begin{tabular}{|c|c|c|c|c|c|c|}
\hline \multirow{2}{*}{$\begin{array}{l}\text { Aluno e } \\
\text { Enunciado }\end{array}$} & \multicolumn{5}{|c|}{ Argumentos ou Asserções } & \multirow{2}{*}{$\begin{array}{l}\text { Padrão Moral / } \\
\text { Valor }\end{array}$} \\
\hline & Dado (dado que...) & $\begin{array}{l}\text { Conclusão (então...)/ } \\
\text { Asserção }\end{array}$ & $\begin{array}{c}\text { Garantia (já } \\
\text { que...) }\end{array}$ & Qualificador & $\begin{array}{l}\text { Refutador (a } \\
\text { menos que...) }\end{array}$ & \\
\hline \multirow{3}{*}{ L5 } & $\begin{array}{l}\text { se não fosse proibido seria } \\
\text { muito mais higiênico }\end{array}$ & \multirow{3}{*}{$\begin{array}{c}\text { [O aborto deveria ser } \\
\text { permitido] }\end{array}$} & \multirow{3}{*}{$\begin{array}{c}\text { o aborto não vai } \\
\text { parar }\end{array}$} & & & \multirow{3}{*}{$\begin{array}{c}\text { Raciocínio Moral } \\
\text { Consequencialista / } \\
\text { Ordem Social }\end{array}$} \\
\hline & $\begin{array}{l}\text { ia sobreviver muito mais } \\
\text { pessoas [muito mais } \\
\text { mulheres sobreviveriam] }\end{array}$ & & & & & \\
\hline & $\begin{array}{l}\text { não ia existir tantas coisas } \\
\text { clandestinas }\end{array}$ & & & & & \\
\hline $\mathrm{Ke}, \mathrm{L} 8$ & & $\begin{array}{c}\text { O aborto seria } \\
\text { proibido/não seria } \\
\text { permitido / o aborto é } \\
\text { [deve ser] proibido }\end{array}$ & & & $\begin{array}{l}\text { exceto em casos } \\
\text { extremos: } \\
\text { estupro e risco de } \\
\text { morte / a não ser } \\
\text { duas questões, } \\
\text { é... o estupro ou } \\
\text { sei lá..ta em risco } \\
\text { de vida ou morte } \\
\text { a mãe da criança }\end{array}$ & $\begin{array}{l}\text { Moral Intuitiva / } \\
\text { Respeito à Vida }\end{array}$ \\
\hline B3, C171c & $\begin{array}{c}\text { a mulher não tem controle } \\
\text { sobre a situação / essas } \\
\text { coisas...que ela não pôde } \\
\text { controlar nem nada... }\end{array}$ & $\begin{array}{c}\text { em caso de doença } \\
\text { mental [não claro se } \\
\text { mãe ou filho] a } \\
\text { mulher deve abortar / } \\
\text { [no caso de] alguma } \\
\text { doença assim né, } \\
\text { problema mental [o } \\
\text { aborto deve ser } \\
\text { permitido] / Seria } \\
\text { feito o aborto }\end{array}$ & $\begin{array}{l}\text { ninguém é } \\
\text { obrigado a } \\
\text { assumir riscos } \\
\text { oriundos de um } \\
\text { acontecimento } \\
\text { sobre o qual não } \\
\text { se tem controle }\end{array}$ & $\begin{array}{c}\text { em caso de } \\
\text { doença mental } \\
\text { [não claro se } \\
\text { mãe ou filho] / } \\
\text { alguma doença } \\
\text { assim né, } \\
\text { problema } \\
\text { mental }\end{array}$ & & $\begin{array}{l}\text { Raciocínio Moral } \\
\text { Deontológico / } \\
\text { Acidentes e Não- } \\
\text { Responsabilidade }\end{array}$ \\
\hline
\end{tabular}

\section{Figura 1: Trecho da tabela de argumentos correspondente ao grupo D.}

É importante notar que a linha da tabela marcada com a sigla L5 significa que a aluna "L" proferiu uma fala no quinto turno da interação. O seu argumento continha mais de um dado para uma mesma conclusão, o que pode ser observado pela estrutura da tabela. Na segunda linha da tabela temos uma asserção que foi comum para mais de um aluno, no caso para a aluna "L" que manifestou tal opinião no oitavo enunciado e para a aluna "K", que o manifestou por escrito, na folha de questões, por isso a marcação "Ke". Na terceira linha da tabela também há mais de um aluno, pois, novamente, a conclusão foi a mesma tanto para a aluna "B" (B3) como para a aluna "C" (C171c), que manifestou sua concordância com “B” e, por isso está marcada também com um "c". 
Como podemos ver acima, as partes do argumento que representam as colunas são: dados, conclusões, garantias, qualificadores e refutadores. As garantias nem sempre são explícitas nas falas dos alunos, e, quando são, aparecem grafadas em negrito. Não há uma coluna para o elemento "apoio", por este ter se mostrado um tanto raro nas falas dos alunos, e também porque, neste trabalho, a classificação das partes do argumento segundo Toulmin (2003) está subordinada ao propósito de identificar os valores a partir das garantias. No único caso em que o apoio surge nos dados deste trabalho, ele aparece no lugar da garantia.

Após a identificação dos argumentos, foi acrescentada, nas mesmas tabelas, uma coluna adicional, representando os padrões morais e os valores ou crenças relacionados às garantias expressas pelos argumentos dos alunos. Há pelo menos um padrão moral e um valor ou crença para cada tipo de garantia identificado. Padrões morais - raciocínio moral consequencialista, raciocínio moral deontológico, moral emotiva e moral intuitiva - e valores encontram-se na mesma coluna da tabela.

Outras tabelas presentes neste trabalho se referem aos tipos de valores encontrados (Tabela 1), aos enunciados nos quais foram encontrados conceitos científicos (Tabela 2), aos valores associados aos conceitos científicos e suas posições nos argumentos (Tabela 3), e ao número de enunciados com cada valor e padrão moral (Tabela 4). Na segunda tabela, são relacionados também os padrões morais associados e as funções dos conceitos científicos nos argumentos.

\subsection{Referenciais teóricos e categorias de análise}

As categorias de padrões morais e de valores foram desenvolvidas de formas distintas. Assim, os padrões morais aqui utilizados são categorias a priori, e seguem a classificação utilizada por Sadler \& Zeidler (2004, 2005), ou seja, cada argumento foi classificado como raciocínio informal racionalista deontológico, raciocínio informal racionalista consequencialista, raciocínio informal emotivo e raciocínio informal intuitivo, significando aqui o mesmo que raciocínio moral deontológico (raciocínio baseado em princípios), raciocínio moral consequencialista, moral emotiva e moral intuitiva. Já os valores, como são muito dependentes do tipo de questão sociocientífica discutida, são analisados neste trabalho como categorias emergentes (MORAES, 2005, in GALIAZZI \& FREITAS, 2005). 
Os valores atribuídos aos argumentos dos alunos são desenvolvidos da mesma forma que no trabalho de Kolsto (2006). Assim, tais valores representam as ideias às quais os participantes apelavam como critérios ou garantias para suas decisões sobre o aborto. Como os estudantes expressavam suas garantias de diversas formas ou não as expressavam, os valores foram interpretados a partir dos elementos presentes nos enunciados. Essas categorias foram analisadas com relação à sua aplicabilidade e ajustadas no decorrer da análise para que se tornassem representativas dos valores relacionados aos argumentos analisados (KOLSTO, 2006).

O estudo de formas de pensamento como os tipos de raciocínio informal e os valores é estimulado por autores como os próprios Sadler \& Zeidler (2005), que defendem, em seu trabalho com alunos de cursos superiores e dilemas de engenharia genética, que é necessário que trabalhos explorem os padrões de raciocínio de outras populações alvo, além da exploração do raciocínio informal em resposta a outros problemas sociocientíficos.

\section{Resultados e Análise dos Dados}

Os argumentos obtidos a partir da discussão dos alunos, assim como os padrões morais e valores associados, podem ser observados nas tabelas do anexo IV, sendo uma tabela representativa de cada um dos grupos.

Seguindo a classificação de Patronis et al. (1999), que caracterizou os argumentos dos alunos em quantitativos, semi-quantitativos e qualitativos, todos os argumentos deste trabalho seriam categorizados como qualitativos, pela própria natureza da questão discutida, embebida em valores morais. Como os objetivos desta pesquisa também são qualitativos e predominantemente descritivos, a emergência de padrões de raciocínio informal nos indivíduos é considerada mais significante que o número de indivíduos que apresentam tais padrões (SADLER \& ZEIDLER, 2004).

Tendo como base as categorias desenvolvidas por Sadler \& Zeidler (2004), aqui identificamos os seguintes padrões morais a partir dos argumentos dos alunos: 


\subsection{Padrões Morais Racionalistas}

Os alunos apresentavam um padrão moral racionalista quando forneciam justificativas e garantias que representam deliberações racionais sobre o assunto. Esse tipo de raciocínio, por sua vez, pode se apresentar na forma de duas perspectivas diferentes:

8.1.1. Raciocínio Moral Consequencialista: é o padrão moral representado por escolhas que levam em consideração as conseqüências das ações. Podemos observar tal padrão no seguinte trecho, retirado da fala de uma aluna do grupo E:

M7: “(...) não acho que devia legalizar [o aborto] porque senão todo mundo ia querer fazer sexo e ia querer abortar e não tá certo..."

Aqui, a aluna baseia sua argumentação nas conseqüências indesejadas que uma possível legalização do aborto traria. Diversos valores podem aparecer associados a um raciocínio consequencialista, mas serão discutidos mais adiante.

8.1.2. Raciocínio Moral Deontológico: os alunos apresentando esse tipo de padrão moral utilizam princípios morais como as principais garantias de seus argumentos. A mesma aluna do exemplo anterior utiliza também um padrão moral baseado em princípios:

M7: “(...) não [o aborto não deveria ser permitido], porque você tá matando um bebê, então é errado, como se matasse uma pessoa..."

Aqui, o princípio segundo o qual é errado matar é o principal valor envolvido na justificação da posição da aluna, portanto, consideramos o exemplo um caso de raciocínio moral deontológico.

É interessante destacar que as duas proposições são produzidas pela mesma aluna, no mesmo turno de fala, o que corrobora o fato, já observado por Sadler \& Zeidler (2005), de que muitas vezes as pessoas mostram evidências de integração dos múltiplos padrões de raciocínio informal em resposta a um mesmo cenário. Segundo os 
autores, os padrões podem ser usados de forma coordenada, quando um padrão moral complementa o outro, ou conflitante, quando as conclusões dos dois tipos de raciocínio não são compatíveis. Os padrões morais racionalistas - deontológico e consequencialista - podem também aparecer integrados com os outros dois tipos de raciocínio informal, seja a moral emotiva ou a moral intuitiva. A apresentação de múltiplos padrões de raciocínio poderia ser atribuída, em parte, ao reconhecimento das várias perspectivas que podem influenciar as posições tomadas em resposta aos cenários sociocientíficos.

\subsection{Influência do Afeto: Moral Emotiva e Moral Intuitiva}

Esses dois tipos de padrão moral estão relacionados com o âmbito afetivo das questões sociocientíficas e, por isso, correm o risco de ser interpretados como falta de conhecimento, arbitrariedade ou argumentação não-consistente. Na própria literatura específica, como vários pesquisadores apontam, o papel do afeto e das emoções no funcionamento moral tem sido negligenciado em pesquisas passadas, assim como o fato de que considerar os aspectos particulares da vida de alguém (família, escola, colegas, ambiente de trabalho, relações íntimas) tem um papel normativo na tomada de decisões morais e na formação do caráter (ZEIDLER et al., 2005; SADLER \& ZEIDLER, 2004; ZEIDLER \& SCHAFER, 1984; ZEIDLER et al., 2002).

Zeidler \& Schafer (1984) produziram algumas das primeiras evidências empíricas sugerindo a importância das emoções na resolução das questões sociocientíficas. Sadler \& Zeidler (2004), posteriormente, estenderam a investigação sobre o papel das emoções no raciocínio informal sobre questões sociocientíficas. Ambos os estudos focaram nas reações, percepções, argumentação e resoluções dos estudantes frente a questões de engenharia genética, confirmando o papel importantíssimo da emoção para a negociação de questões sociocientíficas (ZEIDLER et al., 2005).

Segundo Sadler \& Zeidler (2005), os papéis da empatia, da preocupação com os outros ou da simpatia são de particular interesse na exploração das questões sociocientíficas. Altos níveis de engajamento emocional (afetivo), associados à habilidade de regular e controlar tal engajamento emocional através de mecanismos comunicativos e sociais, levaram a maior resiliência, respostas empáticas, comportamento pró-social e comportamentos de lidar construtivamente com as 
questões. As emoções também parecem ter um efeito facilitador em termos de engajamento dos estudantes com questões controversas.

No presente trabalho, assim como em Sadler \& Zeidler (2004), foram identificados dois padrões morais que representavam aproximações afetivas à questão do aborto, como explicados a seguir.

8.2.1. Moral Emotiva: argumentos com tal padrão moral apresentam um foco na preocupação com o bem-estar dos outros e na empatia. Em uma perspectiva relacional ou afetiva, os estudantes muitas vezes se colocavam no lugar da pessoa fictícia que vivenciava o dilema moral, justificando suas posições com base em sentimentos de justiça e/ou identificação.

A aluna do grupo A apresenta um padrão moral emotivo ao dizer:

G26: “(...) num contexto geral eu seria contra [a prática de aborto] porque é uma vida e poderia ser você.”

$\mathrm{O}$ argumento se encaixa nessa categoria pois justifica a conclusão - contra o aborto - utilizando como base a ideia de reciprocidade, de acordo com a qual a pessoa se coloca no lugar daquela que estaria sendo prejudicada, o que dirige a sua decisão, através da empatia, em favor, no caso, do feto.

Outro exemplo é o caso da aluna do grupo B, abaixo:

G99: "Ah, mas eu acho que [ter um filho] vai estragar a vida de uma menina, e eu acho que [o aborto] devia ser legalizado (...)"

Aqui, a aluna mostra preocupação e empatia com a garota fictícia que se encontra frente ao dilema de fazer ou não um aborto. Esse caso nos mostra, mais uma vez, como os padrões de raciocínio moral podem aparecer integrados, pois, juntamente com o padrão moral emotivo, nessa proposição podemos enxergar uma justificativa racionalista consequencialista, relacionada às implicações da gravidez na vida de uma adolescente. Nesse caso, os dois padrões morais se combinam de maneira coordenada, pois concorrem no sentido de justificar a mesma conclusão.

A utilização de padrões morais emotivos não deve ser subestimada em termos de habilidades cognitivas ou capacidade de resolução de questões. Mesmo que não 
estimulados normalmente nas salas de aula, tais padrões morais têm grande relevância para a forma como as pessoas tomam decisões. No trabalho de Sadler \& Zeidler (2004), metade dos sujeitos analisados mostraram que as emoções contribuíram de modo significativo para as considerações e resoluções das questões sociocientíficas em investigação.

Os mesmos autores (2005) observaram que, não apenas os indivíduos se baseiam de forma significativa em emoções para a resolução de questões sociocientíficas, mas também que o raciocínio informal baseado em emoção era geralmente equivalente a abordagens estritamente cognitivas em termos de construções lógicas, como consistência interna e coerência.

8.2.2. Moral Intuitiva: esse tipo de padrão moral é observado quando os participantes não fornecem nenhum tipo de justificativa para suas conclusões, manifestando um tipo de escolha moral que se baseia principalmente na intuição. As razões para as decisões não são explícitas, já que as reações imediatas apresentadas pelos participantes talvez não possam ser explicadas em termos racionais. Segundo Haidt (2001), a principal diferença entre este tipo de padrão moral e o racionalista, é que a intuição ocorre sem esforço, rápida e automaticamente, de modo que o resultado se torna acessível à consciência, mas não o processo. Já o raciocínio ocorre mais vagarosamente, requer algum esforço e envolve pelo menos alguns passos acessíveis à consciência.

No trecho abaixo, temos um exemplo de moral intuitiva manifestada pela aluna "L" do grupo D, ao discutir com a aluna "C", sobre o fato de a pílula do dia seguinte ser ou não equivalente ao aborto:

L130: “A pílula do dia seguinte são só depois de 48 horas...você acha que depois de 48 horas o zigoto vai se fixar no útero?

C131: Sim, o Bruno disse que se fixa depois de 30 horas...ele fixa depois de 30horas...

L132: Tá bom tá bom...

C133: Então você vai ter uma vida...vai lá e você vai matar uma vida....

L134: Tá bom eu ainda acho que isso é diferente...

C135: Por exemplo...sua mãe, ela ta grávida...ela transou lá sem camisinha...

L136: Eu não acho e pronto..." 
$\mathrm{Na}$ discussão acima, "L" não concorda com "C", que justifica seu posicionamento - de que usar a pílula do dia seguinte é similar a fazer um aborto falando sobre a implantação do zigoto no útero e a presença de vida no zigoto. "L" não fornece justificativas para sua posição que, no entanto, não deixa de ser válida. Sadler \& Zeidler (2005) colocam que, mesmo não sendo racionais, os sentimentos intuitivos contribuem com a resolução de questões sociocientíficas e, por isso, podem ser considerados um tipo de raciocínio informal.

O fato de que a utilização de tal padrão moral contribui para a discussão é inegável, principalmente se analisarmos do ponto de vista da interação. No mesmo exemplo dado acima, as proposições da aluna "L", mesmo que não justificadas, contribuíram para que sua colega "C" continuasse se esforçando por justificar o seu ponto de vista, enriquecendo a discussão.

Haidt (2001) propõe que existe uma complexa e intensa relação entre os sistemas intuitivos e racionais, tanto nos processos internos quanto nos sociais. Segundo o autor, o raciocínio moral de uma pessoa pode ter um efeito causal nas intuições de outra pessoa. Nos dados analisados neste trabalho, podemos interpretar uma boa parte dos casos de concordância - aqueles enunciados nos quais os alunos não manifestam um argumento com justificativa, mas demonstram apoio ao enunciado de algum colega, marcados nas tabelas com a letra "c" - como representativos desse fenômeno.

Para o mesmo autor, uma teoria sobre a tomada de decisões com um foco na intuição seria mais compatível com a forma que as pessoas realmente pensam do que uma teoria focada no raciocínio. Isso porque os julgamentos morais seriam geralmente o resultado de avaliações rápidas e automáticas (intuições), que seriam então seguidas por construções racionalistas. Assim, podemos interpretar que o raciocínio moral é utilizado geralmente como uma construção a posteriori, servindo para justificar socialmente uma posição que foi atingida por meio da intuição. O trabalho de Sadler \& Zeidler (2005) corrobora tal ideia, já que o raciocínio informal intuitivo aparece sempre precedendo outros tipos de raciocínio informal.

Utilizando como exemplo o caso do aborto, uma pessoa pode, intuitivamente, considerá-lo uma prática errada, através de processos não conscientes de integração de valores que originam tal posição intuitiva. Uma vez que tal pessoa se encontre em meio a uma discussão sobre o assunto, ela pode então se sentir motivada a gerar uma justificativa racional para sua posição. 
Pode ocorrer, ainda, que a pessoa se encontre diante de intuições conflitantes, pois considera o aborto errado do ponto de vista do feto, mas correto do ponto de vista da mãe. Nesse caso, segundo Haidt (2001), a pessoa passa por vários ciclos de elaborações intuitivas e tentativas de legitimação das mesmas por meio do raciocínio, até que uma conclusão final seja atingida, quando uma justificativa racional melhor for elaborada para defender uma das posições. A influência social nesse processo é evidente, pois, ao falarem sobre evidências, justificativas e fatores envolvidos em um dilema moral, as pessoas podem ajudar a deflagrar uma variedade de intuições conflitantes, o que pode colaborar com um julgamento final mais razoável e elaborado.

Como a ocorrência dos quatro tipos de padrão moral não foi uniforme, é interessante estabelecer uma comparação, que pode ser feita tendo como base os gráficos abaixo:

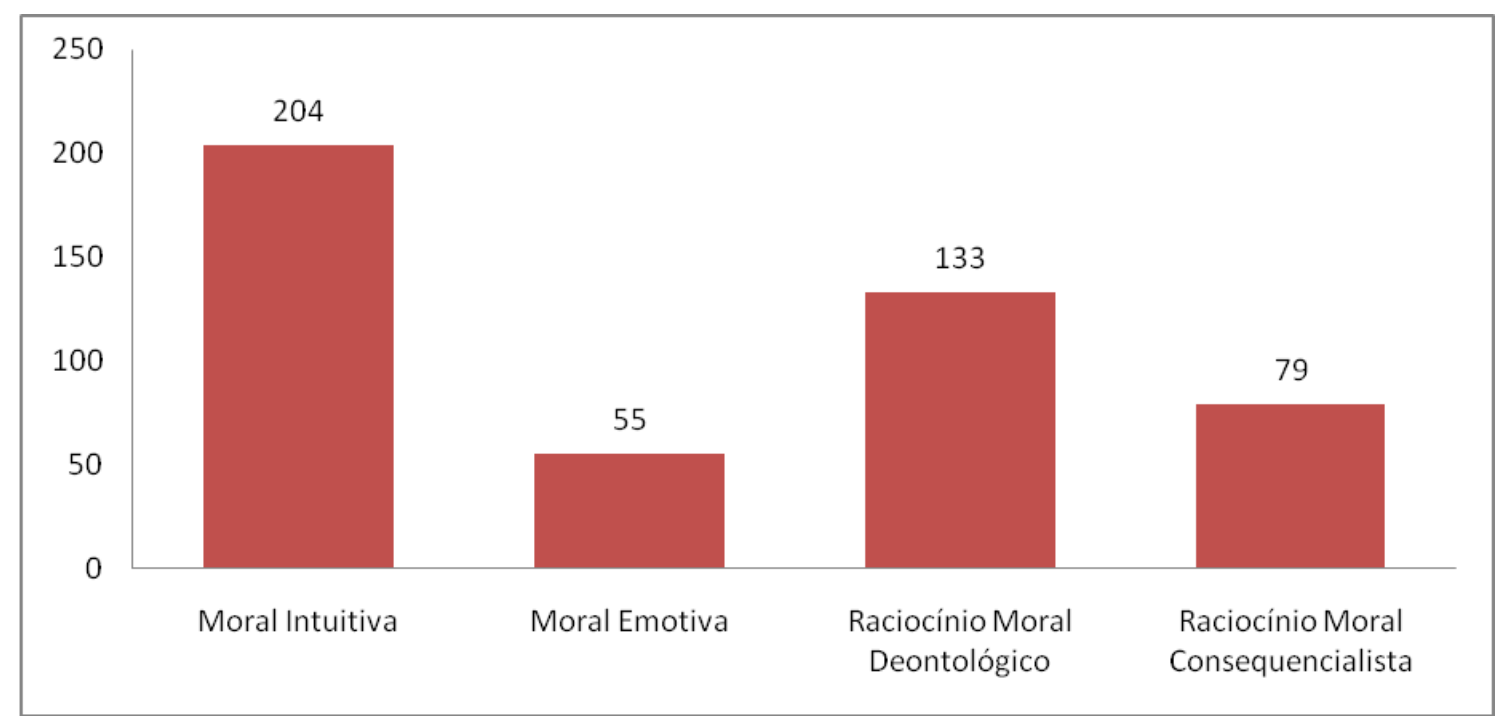

Figura 2: Número de vezes em que surgiram os diferentes padrões morais nos enunciados dos alunos.

Em relação ao total de argumentos e proposições analisados, as proporções foram as seguintes: 


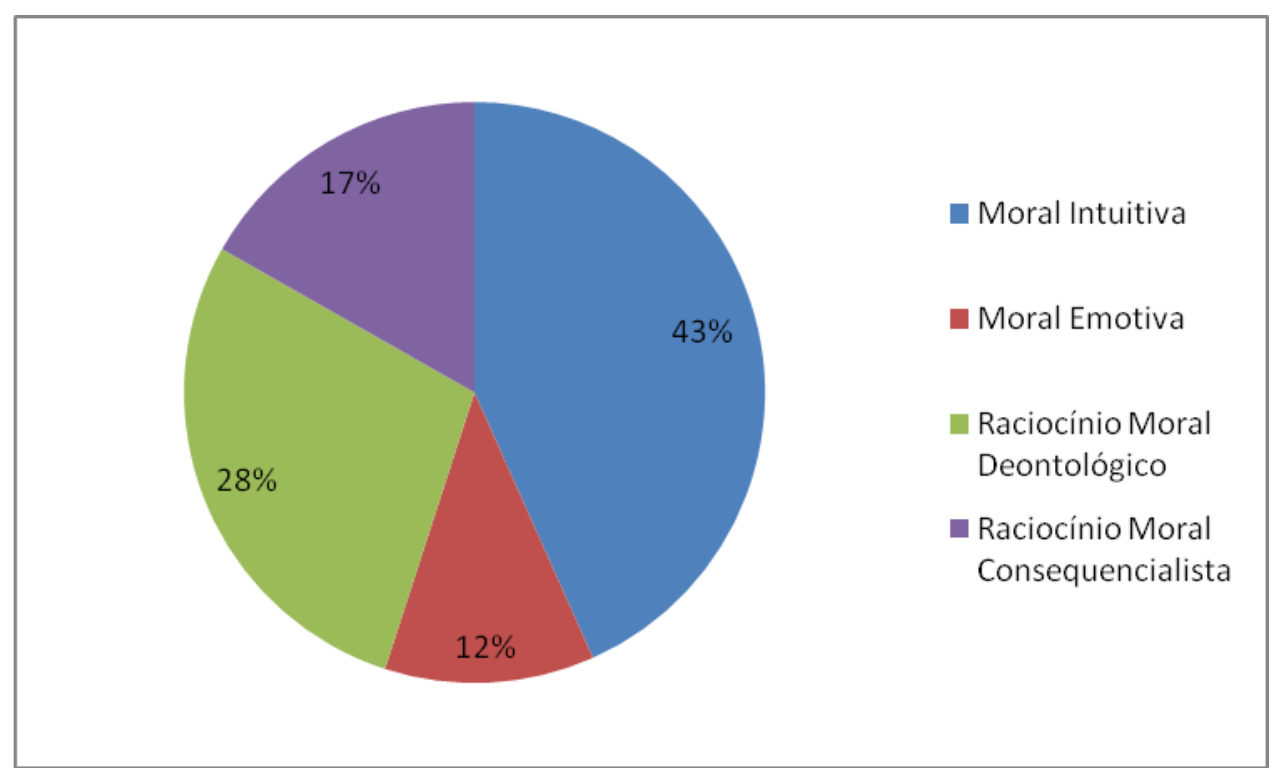

Figura 3: Participação de cada padrão moral no total de proposições analisadas.

A dominância do padrão moral intuitivo é clara em relação aos outros três tipos, o que pode ser decorrência simplesmente do fato de ser mais fácil emitir uma opinião sem justificativa do que proferir um argumento completo. Podemos também pensar que, segundo a teoria de Haidt (2001), tal resultado reflete o fato de que os julgamentos morais se baseiam em posições intuitivas, sendo as justificativas racionais produzidas apenas na tentativa de legitimar tais direcionamentos.

Os raciocínios morais deontológicos aparecem como o segundo grupo de padrões morais mais expressivo, no entanto, se considerarmos os dois tipos de raciocínio informal racionalista (deontológico e consequencialista), estes perfazem quase metade de todas as afirmações proferidas e a maioria dos argumentos completos gerados.

A grande ocorrência de tais padrões morais, em detrimento da utilização do padrão moral emotivo, pode ter relação com o grupo de sujeitos analisados, com a forma como as pessoas realmente tomam decisões, ou então com o contexto de coleta de dados, já que, em uma atividade escolar, provavelmente os alunos devem tentar atingir as expectativas do professor. É bem provável que os alunos tenham acreditado que o que se esperava deles eram respostas com justificativas racionais, ao invés de argumentos suportados por emoções como empatia ou compaixão. 


\subsection{Valores e Garantias: Valores de Justiça X Valores de Cuidado}

Um dos focos deste trabalho, assim como no trabalho de Kolsto (2006), é a identificação dos valores sobre os quais os alunos se baseiam ao tomar decisões sociocientíficas. Os valores podem servir como garantias (garantia no sentido utilizado no padrão de argumentação de Toulmin, 2003) para os argumentos manifestos na discussão sobre questões morais. Dessa forma, é importante analisar, além da ideia por trás de cada argumento como um todo, as garantias específicas que são explicitadas e as garantias que estão implícitas. Neste capítulo, são introduzidos referenciais específicos da área de desenvolvimento e psicologia moral, situados nesta posição no presente trabalho como forma de preservar a sequência do processo criativo da dissertação.

Segundo Brown (1984), o termo "valor" denota preferência em termos de escolha de uma coisa em detrimento de outra por uma noção de que uma é melhor que a outra. Isso pode ocorrer porque um indivíduo considera que uma opção é melhor do que a outra ou então porque o indivíduo gosta mais de uma opção do que da outra. Valores podem ser modos de comportamento (lealdade, bravura, cuidado, respeito), estados finais (felicidade, liberdade, ordem) ou qualidades (beleza, simetria). Para Corraliza \& Berenguer (2000), os valores representam formas de ver o mundo e lidar com ele. Ambas as noções acima são compatíveis com a análise deste trabalho.

Apesar da existência de muitos trabalhos sobre valores e questões ambientais (OREG \& KATZ-GERRO, 2006; CORRALIZA \& BERENGUER, 2000), não foram encontrados, na literatura sobre argumentação e questões sociocientíficas, trabalhos descrevendo os valores utilizados por estudantes desta faixa etária (13-14 anos) na discussão do tema aborto. No entanto, na área da psicologia moral, a temática do aborto esteve relacionada a um importante debate acadêmico, pois foi a fonte dos dilemas usados por Carol Gilligan para estabelecer um contraponto, ou uma nova abordagem, em relação à predominante teoria de desenvolvimento moral de Lawrence Kohlberg. Valores até então subestimados passariam a receber maior atenção por parte dos psicólogos morais (DONLEAVY, 2008).

A teoria de Kohlberg sobre o desenvolvimento moral, proposta em 1969, é uma das principais referências dos autores que estudam moralidade e, apesar de não estar isenta de críticas, é muito utilizada. Segundo o autor, o raciocínio moral das pessoas se 
desenvolve baseado em conceitos de justiça, direitos e obrigações, de acordo com a idade, a educação recebida e a experiência. Há três níveis de desenvolvimento moral e seis estágios. No nível pré-convencional, que compreende os estágios 1 e 2 , o raciocínio moral é focado em punições e recompensas, algo do tipo "o que é punido está moralmente errado" ou "o que satisfaz as necessidades e desejos é o correto"; no nível convencional, o foco se dirige à aprovação obtida das relações interpessoais (estágio 3) e a regras sociais e leis, que são internalizadas (estágio 4), assim, para o indivíduo no nível convencional, geralmente a lei representa o que é moralmente certo, buscando-se a manutenção da ordem social. Por fim, há o nível pós-convencional, nos estágios 5 e 6 , em que o raciocínio moral leva em conta não mais a regra, mas os princípios morais universais de justiça e equidade sobre os quais as regras são construídas (GUMP et al., 2000; KARPIAK \& BARIL, 2008, SHERBLOM, 2008).

Por mais de três décadas, a teoria de desenvolvimento moral de Kohlberg tem representado o paradigma mais impactante e pesquisado da área. Não menos importantes são as críticas feitas à sua teoria. Uma das mais destacadas objeções acusa Kohlberg de etnocentrismo e de generalização imprópria, já que seus princípios e valores universais de justiça, importantes na definição dos últimos estágios de moralidade, seriam representativos apenas de amostras compostas de indivíduos do sexo masculino, anglo-americanos e brancos (GUMP et al., 2000). Além disso, para muitos autores, ao focar sua atenção no papel da cognição para o desenvolvimento moral, Kohlberg teria negligenciado outras dimensões morais, como o afeto e a intuição (MORTON et al., 2006; HAIDT, 2001).

Carol Gilligan, considerada por muitos a maior crítica da teoria de Kohlberg, apesar de ela própria não aceitar tal rótulo, era amiga próxima de Kohlberg e chegou inclusive a trabalhar em parceria com ele (GILLIGAN, 1998). A Gilligan são atribuídas as principais ideias sobre diferenças de gênero no desenvolvimento moral, pois ela argumentava que a ética da justiça, típica da teoria de Kohlberg, era androcêntrica e não representativa das formas de raciocínio moral preferidas pelas mulheres, que se baseariam em uma ética de cuidado, relacionamentos e responsabilidade (HASTE \& ABRAHAMS, 2008). Gilligan entrevistou diversas mulheres sobre o dilema do aborto e descreveu o que ela observou como a linguagem do egoísmo (responsabilidade voltada para si) e da responsabilidade (voltada para os outros), definindo o problema moral como uma obrigação de cuidar e evitar dor (GILLIGAN, 1977 apud GUMP et al. 2000). 
Em outras palavras, os trabalhos de Gilligan e seus colegas sugeriam que justiça e cuidado representam duas linguagens morais ou formas de discurso moral fundamentalmente diferentes, que as pessoas podem usar ambas as linguagens e que, de fato, elas as utilizam, para responder aos problemas morais e conflitos pessoais. Já que justiça e cuidado não seriam sempre suficientes para resolver um dado problema, as pessoas geralmente tentariam os dois modos, trocariam, voltariam atrás ou utilizariam uma forma combinada da ética da justiça e da ética do cuidado. Apesar da possibilidade de usar as duas linguagens morais, haveria uma clara dominância de um tipo sobre o outro, o que, no trabalho de Gilligan, estava relacionado com gênero (TAPPAN, 2006; JORGENSEN, 2006).

Tradicionalmente, a justiça tem representado uma linguagem moral mais pública e poderosa na cultura ocidental, em detrimento da linguagem do cuidado. Isso leva a uma visão de que o funcionamento moral mediado pela justiça é mais legítimo do que aquele mediado pelo cuidado - legitimidade que estaria ligada a assimetrias de gênero em poder, privilégios e autoridade. A importância de Gilligan no contexto da psicologia moral refere-se justamente ao questionamento dessa tradicional hegemonia da linguagem moral masculina da justiça (TAPPAN, 2006).

Muitos outros autores após Gilligan pesquisaram as diferenças de gênero para raciocínio moral, alguns encontrando tais diferenças, outros negando a validade empírica dessa hipótese (GUMP et al., 2000; KARPIAK \& BARIL, 2008; WALKER \& FRIMER, 2009; ZUCKER, 1999). Há vários pesquisadores também que sugerem que o mais importante é se um dilema específico é melhor resolvido através de uma orientação à justiça ou ao cuidado, ou que o emprego de um raciocínio de justiça ou de cuidado depende muito mais da natureza do dilema enfrentado do que do gênero ou da origem cultural do sujeito (DONLEAVY, 2008; WALKER \& FRIMER, 2009). Essa hipótese explicaria a razão da prevalência da ética do cuidado nas entrevistas que Gilligan fez sobre o aborto, já que o tema elicitaria muito mais ideias de cuidado do que de justiça.

Independentemente dos resultados contraditórios sobre diferenças de gênero, parece haver um consenso sobre a existência desses dois modos de moralidade: a ética da justiça e a ética do cuidado (HASTE \& ABRAHAMS, 2008). Tappan (2006) encara essas duas linguagens morais como duas vozes, ferramentas culturais, ou meios de mediação (WERTSCH, 1998) que estão ligados a diferentes visões de uma relação humana ideal: a voz da justiça refletiria um ideal de equidade, reciprocidade e justiça 
entre as pessoas; já a voz do cuidado refletiria um ideal de conexão, de amar e ser amado, de escutar e ser escutado, de atender e ser atendido. Esses ideais seriam traídos, no caso da justiça, por opressão, dominação, inequalidade e/ou injustiça de tratamento, e, no caso do cuidado, por separação, abandono, falta de atenção e/ou responsividade.

Para Haste \& Abrahams (2008), a ética da justiça está baseada em um modelo de personalidade no qual as pessoas são seres inerentemente separados, com direitos potencialmente conflitantes. Assim, a resolução dos conflitos requer estratégias para balancear direitos e obrigações entre pessoas autônomas e discretas. Por outro lado, a ética do cuidado reflete um modelo em que humanos são conectados e interdependentes, o que origina uma obrigação moral central de manter relacionamentos.

De acordo com Sherblom (2008), Gilligan argumentava que pessoas que raciocinam baseadas em valores de justiça e pessoas que raciocinam baseadas em cuidado diferem em diversos aspectos psicológicos. Os sujeitos orientados ao cuidado assumem um nível de interdependência e conexão com outras pessoas muito mais relacional que a autonomia individual enfatizada pela ética da justiça. Além disso, eles vêem a ação como responsiva e assumem o cuidado como um imperativo moral. A perspectiva do cuidado celebra valores como compaixão e abrange uma epistemologia moral que legitima o conhecimento adquirido afetivamente, como a capacidade de assumir empaticamente a perspectiva alheia ou outros tipos de atenção compassiva ao bem-estar dos outros.

Em suma, Gilligan, em seu livro "In a Different Voice", estabeleceu como conceitos essas duas formas ou concepções de moralidade: a ética do cuidado, que coloca o desenvolvimento moral em função do entendimento da responsabilidade e de relacionamentos, além da preocupação com os outros, e a ética da justiça, que atrela o desenvolvimento moral ao entendimento de regras e direitos, e padrões abstratos de certo e errado (DONLEAVY, 2008; JORGENSEN, 2006; GUMP et al., 2000; RESNICK, 2008).

No presente trabalho, boa parte dos valores utilizados como garantias ou princípios pelos alunos para discutir as questões referentes ao aborto podem ser agrupados segundo essas duas linguagens morais. Temos, assim, valores que, em função das características descritas acima, representam a ética do cuidado, e outros que representam a ética da justiça.

Por apresentarem similaridades específicas, os valores encontrados foram agrupados por tema em cinco grupos: Questões Sociais; Riscos, Acidentes e 
Responsabilidade; Respeito ao Valor da Vida; Valores Familiares/Relacionais e Regras de Decisão. Temos, na sequência, a descrição de cada valor utilizado pelos alunos ao discutir as questões propostas sobre o aborto neste trabalho, além de uma tabela contendo os valores encontrados:

8.3.1. Questões Sociais: Alguns alunos apresentavam valores que ultrapassam os limites da vida privada, possuindo aplicabilidade ampla e abrangendo temas de relevância global.

A ideia de "ordem social" é um exemplo de valor integrante dessa categoria, na qual os alunos pensavam na questão do aborto como um problema que afeta o bemestar, a saúde ou o futuro não apenas de uma mulher ou uma criança, mas de toda a sociedade ou parte significativa desta.

Essa aluna, do grupo D, concentrou-se na ideia de que o aborto nunca deixará de ser realizado e, portanto, faz mais sentido torná-lo uma prática legal, já que, se o aborto fosse legalizado, haveria mais higiene nas condições de realização da técnica, os números de mortalidade materna seriam menores e as clínicas clandestinas seriam inibidas.

L5: “(...) o aborto não vai parar... mesmo clandestino ou não... acho que por meio lado, certo lado, o B tá certo, porque se fosse, como é que chama... legislado... se não fosse proibido o aborto no Brasil, seria muito mais higiênico, ia sobreviver muito mais pessoas e não ia existir tantas coisas clandestinas (...)”

A defesa do aborto como questão de saúde pública é um dos importantes argumentos daqueles que defendem a sua legalização.

No argumento seguinte, o ideal de ordem social também é evocado, mas como um impedimento à legalização do aborto.

Grupo E, M7: “(...) não acho que devia legalizar [o aborto] porque senão todo mundo ia querer fazer sexo e ia querer abortar e não tá certo...”

Esse tipo de argumento consequencialista que considera que uma determinada concessão pode levar à legitimação de atos moralmente piores do que aquele inicialmente concedido também é chamado, na literatura, de "slippery slope" ou "rampa 
escorregadia", se traduzirmos para o português. Foi um dos valores identificados por Sadler \& Zeidler (2004), em suas discussões sobre engenharia genética. É um argumento importante daqueles que se colocam contra a legalização da eutanásia, por exemplo, já que a liberação de tal prática poderia levar a muitas mortes prematuras desnecessárias.

Aqui, a ética do cuidado é evocada pelo sentimento de responsabilidade pelas consequiências de uma legislação precipitada, ao mesmo tempo que a ética da justiça transparece através de ideais de certo e errado.

Bem mais comuns, os argumentos que faziam referência ao problema social da orfandade mostraram, nos grupos $\mathrm{C}$ e $\mathrm{E}$, um valor de ordem social sempre relacionado a uma abordagem consequencialista da questão do aborto. Praticamente todos os argumentos desse tipo tratavam do problema de a mãe morrer e deixar o filho sozinho ou dos casos em que a mãe dá a luz e não cuida da criança, deixando-a desamparada. $\mathrm{O}$ valor era utilizado para justificar a escolha pelo aborto, no caso de risco de vida da mãe, ou para justificar o aborto quando a mulher não tem condições de criar o filho.

Grupo E, C35: “é, não adianta o filho não ter como se cuidar... depois manda pro orfanato e a criança fica com a cabeça meio..."

Paradoxalmente, mesmo que defendam o aborto, a linguagem moral predominante nesses argumentos parece ser a ética do cuidado, tendo em vista a preocupação com a criação e o desenvolvimento de uma criança desamparada. Já no caso dos argumentos que focam a saúde pública e a impossibilidade de combater a prática do aborto, também são evocados ideais universais de justiça e direitos, o que permite que esta categoria possa ser abordada através da ética do cuidado ou da justiça.

Vários outros argumentos que trazem valores relativos a questões sociais foram justificados com base no direito da mulher de agir sobre seu próprio corpo, seja por necessidade, em virtude de eventos sobre os quais ela não tinha controle ou por conveniência. Os alunos que utilizaram este valor defendiam o aborto em alguma circunstância, como no caso de risco de vida da mulher, no caso de gravidez por acidente, no caso de estupro ou dependendo da vontade da mulher.

\section{Grupo E,}

G3: "eu acho que deveria permitir em qualquer caso. 


\section{C4: por quê?}

G5: porque a partir do momento em que uma mulher está para ter um filho e ela não quer ter esse filho ela tem o direito de abortar..."

Grupo A, G22: "Eu acho que o aborto em algumas circunstâncias é... pode ser favorável ou não... por exemplo, foi o que o professor disse... se uma mãe está prestes a morrer por causa do aborto eu acho que aí deveria ser uma prática proibida, quer dizer, concedida, porque de qualquer jeito uma pessoa iria morrer, então eu acho que aí no caso o aborto seria favorável (...)"

Tais argumentos, ao mesmo tempo que evocam a ética da justiça, em função da alusão à equidade e aos direitos que cabem à mulher, também podem ser movidos pela ética do cuidado, como um sentimento de compaixão pela mulher que corre o risco de morrer no parto.

É esperado que valores de ordem social e direitos da mulher evoquem as duas linguagens éticas (justiça e cuidado), dado que são questões gerais e amplas o suficiente. Os últimos níveis de desenvolvimento moral, que dizem respeito a valores universais que estão acima de regras e leis são bem parecidos nas teorias de Kohlberg e de Gilligan.

8.3.2. Riscos, Acidentes e Responsabilidade: Muitos argumentos estabeleciam relações entre riscos envolvidos, conhecimento de riscos, poder de ação sobre os riscos e responsabilidades que deveriam ou não ser assumidas de acordo com a relação causal estabelecida pelo valor utilizado. As formas sob as quais esse tipo de valor surgiu foram muito parecidas com as categorias desenvolvidas por Kolsto (2006) em seu trabalho, já que a questão sociocientífica trabalhada com seus alunos podia ser considerada como uma questão "risk-focused". Muitas vezes tais valores surgiam associados à ética da justiça, quando estabeleciam direitos ou obrigações. A ética do cuidado se manifestava aliada a sentimentos de compaixão e à capacidade de assumir a perspectiva alheia.

Uma das formas nas quais tal valor se manifestou se refere à aceitação de riscos. Esse tipo de valor é idêntico ao identificado por Kolsto (2006) como suportando o tipo de argumento chamado por ele de "Small Risk Argument". No trabalho do autor, alguns alunos tomaram suas decisões considerando que os riscos são uma parte natural da vida. 
Aqui, a aluna utiliza esse valor para defender que não se deve praticar o aborto, mesmo quando a menina é muito jovem e corre um maior risco com a gravidez:

Grupo D, C40: “não B., não é necessariamente morrer no parto... tem muita criança hoje em dia que tem filho com $10 \ldots 10$ não, mas tipo 12, 13, 14 anos que não morre no parto e tem o filho..."

O argumento é deontológico e traz ideais de obrigações (no caso, obrigação de ter o filho, uma vez que a menina está grávida) e de certo e errado, representando a ética da justiça.

Pensando de outra forma, para alguns alunos os riscos deveriam ser evitados, e não aceitos. Essa manifestação foi idêntica a um valor identificado no trabalho de Kolsto (2006), chamado por ele de "precautionary principle". Apenas uma aluna o utilizou dessa forma, para defender a possibilidade de realização do aborto quando a grávida é muito jovem. Em virtude da clara preocupação com a garota do dilema, podemos classificar este valor como um valor relacionado à ética do cuidado.

Grupo D, B25: “mas a pessoa não tá preparada pra isso... ainda não está preparada... se for uma menor de idade... nossa idade mais ou menos... ela não tá preparada o corpo físico e mental não tá nada preparado... (...)"

B39: "ela vai morrer no parto (...)"

B41: “mas eu tô falando assim... mas você tem risco de morrer... você não deixa de ter risco..."

Outro valor representante das considerações sobre riscos e responsabilidade seria o princípio de que toda pessoa deve ser responsabilizada pelos riscos que assume por vontade própria. Como se trata de um princípio, tal valor aparece sempre associado a um padrão de raciocínio moral deontológico:

Grupo D, C63: "eu acho assim, que a Jane ela devia assumir a criança porque mesmo que foi uma coisa não prevista por ela... aconteceu, então agora ela assume, porque que nem a K. disse ela não foi obrigada a transar com ele... foi uma decisão 
conjunta... e eles sabiam dos riscos que poderia ter... depois... devia trancar a faculdade que nem a L. disse e procurar um trabalho pra poder sustentar o filho... pedir ajudar pros pais se não conseguir..."

Neste argumento, o fato de a gravidez, mesmo não prevista, ter acontecido, além do fato de o casal ter conhecimento anterior dos riscos, torna-os obrigados a assumirem a responsabilidade pelo cuidado do filho. Tal obrigação também pode ser interpretada como uma justiça que deve ser feita, como se o ato sexual sem proteção devesse ser punido com o dever de assumir o filho, caracterizando o uso da ética da justiça.

Por outro lado, podemos dizer que a possibilidade de livre escolha das ações gera uma responsabilidade sobre as conseqüências das mesmas ações. Quando a questão da responsabilidade se torna o foco do argumento, o mesmo valor pode estar expressando um aspecto da ética do cuidado.

De forma contrária à descrita acima, surgiu também o princípio que estabelece que um sujeito não é obrigado a assumir a responsabilidade sobre consequiências de fatores que fujam ao seu controle. Foi um valor bastante utilizado por aqueles que defendem a possibilidade de realização de aborto nos casos em que a mulher é estuprada. Representa a ética do cuidado, pois centraliza a atenção na compaixão pela mulher que não teve controle sobre o início daquela gravidez, podendo também ser uma expressão da ética da justiça, dado que não seria justo alguém ter obrigações derivadas da violação de seus próprios direitos.

Grupo A, T10: "eu concordo [com a lei brasileira, que permite o aborto no caso de estupro] porque estupro é... é uma coisa que não é da sua vontade... não tem porque você ficar grávida... você... é... eu acho...”

Surgiu ainda na discussão a ideia de que o arrependimento poderia livrar alguém do ônus que é conseqüência de determinada ação consciente. Nesse caso, a linguagem moral utilizada é exclusivamente a ética do cuidado, dado que não importam os princípios de certo e errado, desde que haja arrependimento. Para os usuários deste valor, a ação é e pode, legitimamente, ser determinada pela emoção.

Grupo A, T6: "Eu acho que a pílula do dia seguinte é liberada, porque é um arrependimento mais ou menos da pessoa... eu acho que... é, é liberada..." 
8.3.3. Valores Familiares/Relacionais: em grande parte das vezes, os valores utilizados pelos alunos diziam respeito a questões familiares e privadas, principalmente no sentido de estabelecer relações de hierarquia e valor entre diferentes áreas da vida, além de determinação de papéis, priorização de atividades e considerações sobre impactos futuros de decisões. É interessante notar que todas as vezes que estes tipos de argumentos foram usados, eles estavam associados à linguagem ética do cuidado, exatamente por evocarem ideais de relacionamento, conexão, interdependência, responsabilidade e cuidado.

Surgindo diversas vezes como valor familiar, a ideia de cuidado parental parece representar um importante papel no imaginário dos adolescentes analisados, estabelecendo a necessidade de cuidados que um bebê requer, a importância desses cuidados e da relação parental, além da responsabilidade cabível ao pai, à mãe e até aos avós de uma criança recém-nascida.

Em alguns casos os argumentos estabeleciam, de forma absoluta, a importância da relação mãe-filho ou da relação pai-filho. É o caso do raciocínio informal da aluna M abaixo:

Grupo E, M24: “(...) também colocar uma babá seria muito ruim, porque se o bebê for criado por uma babá ele vai ficar com a cabeça totalmente... porque ele não vai poder ver os pais nunca se os dois estão indo trabalhar e estudar, eles nunca vão ter tempo pro filho então eles não vão poder ter uma relação boa, como uma família de verdade, então eles teriam que conciliar isso...(...)"

Uma aluna, para se opor à prática do aborto em qualquer circunstância, recorreu à importância da maternidade, mas em um sentido biológico:

Grupo D, C24: "Não, mas pensa assim, mesmo assim, é um filho seu, mesmo sendo com uma pessoa que você não quer numa situação inoportuna que aconteceu é um filho seu, vai ter seu gens lá tem seu sangue lá tem seu DNA lá tem seus óvulos lá... mesmo você não querendo é seu filho..."

Em alguns argumentos, os alunos atribuíam aos pais ou aos avós a incumbência de realizar determinadas tarefas relativas ao cuidado de um bebê ou à criação geral da criança. A ética do cuidado fica clara quando se observa que, para exercer o cuidado 
parental, muitas vezes são necessários sacrifícios, como começar a trabalhar ou parar de estudar (no caso de um pai muito jovem).

Grupo C, D25: "Eu acho que ela devia pedir ajuda para os pais e para os pais do cara que fez isso com ela... não... o cara não teve nada... ele não fez nada de mais... mas eu acho que os pais do namorado dela e os pais dela deviam ajudar... trabalhar... é como se fosse um meio filho de cada família..."

Grupo D, C76: "Sim mas eu acho que ele tem que parar os estudos, porque como é que ele vai tipo... pensa comigo... ele tem a Jane... a Jane tá grávida ela não pode ficar o dia inteiro sozinha... é sair pra trabalhar às 7 da manhã e voltar às 10 da noite... ela tá grávida... precisa de alguém pra cuidar dela... entendeu?”

É interessante notar que esse tipo de valor familiar, relacionado ao cuidado parental, surge em muitas falas como sendo de igual importância ou mais importante do que outros aspectos da vida, como educação e casamento, nunca como algo que não devesse ser priorizado, denotando, novamente, a ética do cuidado.

Grupo B, G246: “(...) se não tiver amor, acho que ele deveria cuidar do filho sim, mas não precisaria casar..."

Grupo A, G35: "Ele escolhe um período de estudo e outro de trabalho, porque ele não pode largar os estudos mas também não pode deixar a Jane na mão né...”

Os alunos também lembraram que o cuidado parental gera trabalhos que devem ser executados pela mãe e pelo pai, que dividem as tarefas. Em geral, os alunos estabeleciam que a mãe é a principal responsável por cuidar do bebê, enquanto o pai é o principal responsável pelo sustento da família. Em outros casos a divisão de tarefas era mais igualitária e menos ligada a papéis de gênero.

Grupo E, M18: "Eu acho que ela devia conciliar as duas coisas... ela não tinha que parar de trabalhar totalmente, ela deveria pedir uma licença e tudo pra cuidar do bebê... e o namorado, marido dela continuar trabalhando pra ter uma renda pra cuidar do bebê (...)" 
Grupo E, M24: "É, acho que eles tinham que se dividir, pra não ficar muito pesado pra nenhum dos dois... ele não precisaria parar totalmente de estudar... ele podia estudar de noite e trabalhar de manhã ou de tarde... e ela também, porque senão ficaria muito pesado pra um dos dois (...) os dois estão indo trabalhar e estudar, eles nunca vão ter tempo pro filho então eles não vão poder ter uma relação boa, como uma família de verdade, então eles teriam que conciliar isso... ver direito pra poder não prejudicar nenhum dos dois, nenhum dos dois pode nem trabalhar mais nem perder nada..."

Ainda como valores familiares, temos aqueles casos que estabelecem a importância dos estudos e da carreira para uma pessoa jovem, valores utilizados frente à perspectiva de uma gravidez não-planejada em uma adolescente. A ética do cuidado surge associada à necessidade de dinheiro para exercer o cuidado.

Grupo D, L75: “(...) eu acho que assim, ele não precisa parar com os estudos... sabe por quê? Como ele tá entrando em um curso de engenharia agora... eu acho que ele deveria entrar em uma empresa pra fazer um estágio de manhã e fazer a faculdade à noite, o curso... porque eu acho que é assim é bem melhor (...)"

Grupo A, M37: "Eu acho que ele devia começar a trabalhar sim, porque ele tem que sustentar, o filho é dele, mas não parar de estudar porque ele podia ter uma carreira estudando..."

Nos casos acima, o valor está relacionado a uma abordagem consequencialista. O mesmo valor podia ser utilizado sob a ótica dos custos que uma gravidez e uma criança implicam, além da importância real ou percebida do dinheiro. Assim, os alunos utilizavam algumas vezes uma perspectiva deontológica, quando estabeleciam o princípio de que "só deve ter um filho quem tem dinheiro" ou então que, "quem não tem dinheiro pode abortar ou não precisa cuidar do filho". A abordagem também era consequencialista quando os alunos faziam elaborações sobre a necessidade de solidez financeira na vida familiar ou as conseqüências negativas da falta de dinheiro em uma família. 
Grupo E, C10: “Ou se não tem condições mesmo, a criança vai morrer de fome aí... melhor nem ter né...” (raciocínio moral consequencialista)

Grupo C, L31: "Sim, claro, daí se... qualquer coisa num puder cuidar do filho, não tem dinheiro, não tem condições de vida próprias pra ter o filho... aí deixa o filho num orfanato... numa instituição do governo, deixa pra outra pessoa cuidar... alguma coisa assim né, porque ajuda sempre tem em qualquer lugar..." (raciocínio moral deontológico)

Para alguns alunos a abordagem consequencialista e/ou emotiva da questão do aborto se manifestava em uma preocupação com as implicações para a vida da mãe, servindo, em geral, para justificar a realização do aborto em alguns casos, como quando a mulher é estuprada ou é muito nova.

Grupo B, G93: "É... eu acho que é assim, pode estragar a vida de uma menina ficar grávida... então o aborto seria mais recomendado... é melhor legalizar o aborto e... porque aí..."

Grupo D, L170: "[lê a questão 7] eu concordo com os dois porque eu acho assim, o aborto, o estupro, eu falei a mesma coisa várias vezes... o caso, coitada da menina, ela é estuprada... ela não precisa carregar o filho... sei lá, depois de 24 horas sei lá pode acontecer... ela pode abortar num sei... quem sabe... e eu acho que a outra parte do... em caso de vida... eu acho que isso não prec... eu acho que isso é um... é um é...”

Em um argumento, que só apareceu uma vez, o aluno demonstra preocupação com a preservação da imagem da menina que fica grávida e se vê diante da situação de ter de ir à escola com a barriga crescendo, relacionada a um pensamento consequencialista. A ética do cuidado é clara pela preocupação com os outros:

Grupo C, C27: “(...) E ela não precisa parar de estudar, ela pode estar indo pra escola... ninguém vai ficar assim... tirando da cara dela... também se tirar...[inaudível]”" 
Para alguns alunos, as questões do aborto ou da pílula do dia seguinte deveriam ser tratadas como itens necessários de planejamento familiar. A ética do cuidado está presente na responsabilidade pelo planejamento.

Grupo B, A20: “(...) é pílula do dia seguinte... você não pode viver tomando ela porque é perigosa, mas eu acho que é assim, se, vai que ela não usou a camisinha ou se a camisinha estourou e não tinha outra, eu acho que ela tem que tomar sim pra caso ela não fique grávida (...)"

Ainda no plano dos valores relacionais, alguns argumentos foram sustentados por ideais sobre a realização trazida pelo casamento ou sobre o amor possível de se desenvolver entre mãe e filho, mesmo sendo este fruto de um estupro. Os ideais de interdependência e desenvolvimento das relações são típicos da ética do cuidado:

Grupo C, L147: “(...) na gravidez fruto de estupro vem muito coisa de emoção... a mãe não sente emoção pelo pai, o pai não sente emoção pela mãe, nenhum dos dois sente emoção pelo filho e aí acha que... o filho vai ser uma desgraça... aí eu não acho que seja uma desgraça... o amor vai crescendo com o tempo..."

Dentro do contexto da criação e manutenção de vínculos afetivos, a ideia referente à possibilidade de um bebê ser cuidado por alguém que não é seu parente também foi um valor utilizado algumas vezes para justificar a criação de uma criança por uma babá ou por um orfanato, como condições preferíveis ao aborto. A compaixão pela criança, que necessita de cuidados, não necessariamente fornecido pelos pais, é evidência da ética do cuidado.

Grupo C, P138: "Eu acho que é assim... tá, tudo bem... estupro... ela não quer ter o filho do cara mas,... poderia ter... ela poderia deixar numas instituições... orfanatos... essas coisas..."

8.3.4. Respeito ao Valor da Vida: esse grupo de valores possui grande importância na discussão sobre o aborto e permitiu aos estudantes resolver várias das questões propostas. Referem-se à atribuição de valor absoluto ou relativo à vida de um ser humano, que é também pesada em relação a outros valores. Provavelmente em função 
de seu caráter amplo e geral, tais valores aparecem associados tanto à ética do cuidado quanto à ética da justiça.

O respeito à vida humana em geral é um valor que constitui uma garantia típica de muitas das opiniões contrárias ao aborto. Representa um princípio segundo o qual a vida de um ser humano não deve ser ameaçada de forma alguma, desde seus primeiros estágios. Como é um princípio, surge preferencialmente como raciocínio moral deontológico e poucas vezes moral emotiva ou consequencialista. É um dos valores identificados por Sadler \& Zeidler (2004) em seu trabalho sobre engenharia genética. Muitas vezes, este valor surge acompanhado da crença de que o início da vida de uma pessoa ocorre na fecundação, mas não necessariamente. $\mathrm{O}$ valor de respeito à vida cabe tanto à ética da justiça quanto à ética do cuidado.

Grupo A, T24: "Eu acho que o aborto não pode ser legalizado porque de qualquer jeito você tá fazendo um assassinato, você tá matando uma pessoa... não pode... é um absurdo isso... eu acho que nunca pode se matar um bebê, uma vida... qualquer coisa... é um ser humano de qualquer jeito..."

Em um argumento de outro grupo, o respeito à vida surge como uma tentativa de minimizar o número de mortes, representando um ideal de cuidado, através da compaixão e também de justiça, já que a decisão é tomada com base na quantificação (princípio abstrato de certo e errado) de mortes consequentes.

Grupo B, Re: “(...) na gravidez de risco é melhor perder o feto do que o feto e a mãe."

Por fim, o valor de respeito à vida surgiu também na forma explícita da reciprocidade e capacidade de assumir a perspectiva alheia (ética do cuidado) no argumento seguinte:

Grupo A, G26: “(...) num contexto geral eu seria contra [o aborto] porque é uma vida e poderia ser você." 
O posicionamento de uma pessoa no lugar da outra caracteriza esta fala como representante da moral emotiva.

Ainda considerando o valor da vida e o respeito a tal valor, podemos pensar que ela recebe uma importância relativa toda vez que se escolhe entre uma e outra, segundo diversos critérios. Ao mesmo tempo que tal valor representa uma forma de se buscar justiça para decidir quem tem mais direito de viver - ética da justiça -, também podemos perceber que tal direito muitas vezes é legitimado por concepções sobre a importância dos relacionamentos - ética do cuidado.

Grupo C, P149: "Eu também concordo que devia abortar [no caso de uma gravidez de alto risco] porque o bebê é um ser que ainda não viveu, não tem ainda seus sentimentos tão formados como os da mãe e... a mãe... eu acho que deveria abortar...”

Dentro do contexto do valor relativo da vida, muitas vezes é atribuído um valor maior à vida da mãe, em função das experiências já vividas por ela. Talvez o fato de a mãe já ter passado por diversas experiências inspire mais compaixão do que o feto, que não tem experiências e nem lembranças. Aqui também há o predomínio da ética do cuidado.

8.3.5. Regras de Decisão: referem-se a valores nos quais podemos identificar algum padrão que o participante utiliza para tomar sua decisão, padrão que não tem, necessariamente, relação com o assunto discutido. Tais valores seriam, então, menos contexto-dependentes, e poderíamos esperar encontrá-los em discussões de alunos envolvendo outros assuntos que não o aborto. Dependendo da forma como são utilizados, podem estar mais comprometidos com ideais de cuidado ou de justiça.

Um tipo de regra de decisão utilizado é o valor que estabelece que uma determinada ação que não se aplicaria em uma situação normal pode ser aplicada frente a uma condição de exceção. É o caso da aluna B, abaixo, que permite o uso da pílula do dia seguinte no caso de estupro por se tratar de um "caso extremo". A compaixão ou a capacidade de assumir a perspectiva da menina estuprada (ética do cuidado) no dilema cria condição para uma exceção à regra, conferindo a possibilidade de fazer um aborto legal. 


\section{Grupo D,}

B150: "Não, aí ela não pode mais tomar a pílula... só se fosse uma menor de idade, abaixo de 18 anos...

A151: Mesmo que ela for estuprada você acha que...

B152: Não ah, aí é um caso extremo..."

Muitas outras vezes os alunos pretendiam comparar casos semelhantes e aplicar regras semelhantes, ou então pretendiam distinguir casos diferentes e defender a nãoaplicabilidade das mesmas regras. Esse tipo de regra de decisão foi um valor bem comum em função da questão que perguntava se a pílula do dia seguinte podia ser considerada um aborto. Como trata de princípios abstratos de certo e errado e classificações que independem de uma abordagem relacional, nesse caso o valor é um bom exemplo da utilização da ética da justiça.

\section{Grupo D,}

K154: "Eu acho que é um método abortivo e eu não acho que deveria ser liberado...
A155: Por quê?
K156: Porque eu sou contra o aborto..." 
Tabela 1: Os valores relacionados à questão do aborto podem estar relacionados à linguagem ética do cuidado, à linguagem ética da justiça ou às duas, dependendo da forma como são utilizados e de suas naturezas. Em negrito aqueles que aparecem exclusivamente em um tipo de linguagem ética.

\begin{tabular}{|c|c|c|}
\hline $\begin{array}{l}\text { Grupos de } \\
\text { Valores }\end{array}$ & $\begin{array}{l}\text { Ética do Cuidado (ideais de conexão, amor, } \\
\text { responsividade, manter relacionamentos, } \\
\text { interdependência, conexão, compaixão, } \\
\text { capacidade de assumir a perspectiva alheia, } \\
\text { responsabilidade, preocupação com os outros } X \\
\text { separação, abandono, falta de atenção) }\end{array}$ & $\begin{array}{l}\text { Ética da Justiça (ideais de equidade, } \\
\text { reciprocidade, justiça, direitos e } \\
\text { obrigações, autonomia individual, } \\
\text { regras e direitos, e padrões abstratos } \\
\text { de certo e errado } X \text { opressão, } \\
\text { dominação, inequalidade e/ou injustiça } \\
\text { de tratamento) }\end{array}$ \\
\hline Questões Sociais & $\begin{array}{c}\text { ordem social } \\
\text { direitos da mulher }\end{array}$ & $\begin{array}{c}\text { ordem social } \\
\text { direitos da mulher }\end{array}$ \\
\hline $\begin{array}{l}\text { Riscos, Acidentes e } \\
\text { Responsabilidade }\end{array}$ & $\begin{array}{c}\text { evitar riscos } \\
\text { arrependimento e isenção de responsabilidade } \\
\text { riscos, livre-arbítrio e responsabilidade } \\
\text { acidentes e não-responsabilidade }\end{array}$ & $\begin{array}{l}\text { aceitação de riscos } \\
\text { riscos, livre-arbítrio e responsabilidade } \\
\text { acidentes e não-responsabilidade }\end{array}$ \\
\hline $\begin{array}{c}\text { Respeito ao } \\
\text { Valor da Vida }\end{array}$ & $\begin{array}{c}\text { respeito à vida } \\
\text { valor relativo da vida }\end{array}$ & $\begin{array}{c}\text { respeito à vida } \\
\text { valor relativo da vida }\end{array}$ \\
\hline Regras de Decisão & casos extremos e exceções & regras e aplicabilidade \\
\hline $\begin{array}{l}\text { Valores Familiares/ } \\
\text { Relacionais }\end{array}$ & $\begin{array}{l}\text { ambição e segurança financeira } \\
\text { implicações vida da mãe } \\
\text { planejamento familiar } \\
\text { cuidado extra-familiar } \\
\text { cuidado parental } \\
\text { manutenção de relações } \\
\text { auto-sacrifício materno } \\
\end{array}$ & \\
\hline
\end{tabular}

\subsection{Conceitos Científicos na Discussão Sociocientífica}

De acordo com alguns importantes pesquisadores que atuam na área de temas controversos e educação, as questões sociocientíficas devem ser uma forma de ligar experiências escolares com a maneira como os estudantes participam no mundo real (ZEIDLER et al., 2002, SADLER \& FOWLER, 2006). De certa forma, alguns estudantes analisados neste trabalho se aproximam desse ideal, ao trazerem conceitos científicos para a discussão sobre um tema popular e polêmico, que é o aborto.

O surgimento de conceitos científicos dependia do grupo e das questões que os alunos discutiam. Assim, não encontramos nenhum conceito na discussão gravada do grupo A. Nos outros grupos, o surgimento dos conceitos não foi uniforme, mas concentrado em algumas questões e alguns alunos.

Os conceitos que foram utilizados aparecem geralmente associados a algum valor ou crença, que frequentemente serve de garantia para o argumento do aluno. Seguem abaixo alguns exemplos: 
R27: "Eu acho que não é um método abortivo...

G28: Eu também não acho... eu acho que é um método contraceptivo... um método que previne..."

Neste trecho, sobre a pílula do dia seguinte, duas alunas introduzem o conceito de método contraceptivo, explicando-o, como uma forma de garantir que a pílula do dia seguinte é diferente do aborto, já que ela seria apenas um método que previne. A constatação de que a pílula seria um método que previne é crucial para aplicar-lhe a etiqueta de método contraceptivo. A utilização de tais conceitos foi comum na discussão sobre a pílula do dia seguinte. Ainda no grupo B, observamos o aparecimento de outro conceito interessante e bastante relevante para a questão do aborto:

G49: "E no caso do risco, o que seria melhor, um feto ou uma mulher? [inaudível]

R50: se o feto...se o feto... se a mulher morrer o feto vai morrer, mas se o feto morrer a mulher não vai morrer..

G51: eu concordo

A52: eu também concordo...”

Aqui, a aluna " $R$ " tenta estabelecer sua posição através de considerações biológicas. Desta vez, ela o faz utilizando a ideia de interdependência funcional, critério essencial, como já discutido anteriormente, no conceito de indivíduo de Sober (1996). O valor utilizado em conjunto com tal conceito é o de respeito à vida, pois a relação de interdependência concorre para que ambas sejam consideradas importantes e dignas de respeito.

No grupo D, também há uma interessante integração de conceitos na discussão sobre o aborto nos casos de estupro:

C24: "Não, mas pensa assim, mesmo assim, é um filho seu, mesmo sendo com uma pessoa que você não quer numa situação inoportuna que aconteceu é um filho seu, vai ter seu gens lá, tem seu sangue lá, tem seu DNA lá, tem seus óvulos lá... mesmo você não querendo é seu filho..." 
Aqui, os conceitos de gene, sangue, DNA e óvulo, mesmo que não explicados, são utilizados para garantir a importância da relação existente entre a mãe e o feto, do cuidado parental em oposição à possibilidade de aborto.

Alguns usos equivocados de conceitos também apareceram na discussão, como no exemplo abaixo, do grupo E:

M99: “(...) Não eu não proibiria a pílula do dia seguinte porque ah, num sei, ela é um método de ajudar a menina a não ficar grávida assim, tipo, ela pode tomar diariamente antes da gravidez ou quando ela quisesse, se pra ela ou pro parceiro dela a camisinha não for um método que pra eles... eles não gostem na hora de fazer o ato sexual... é uma boa ajuda pra eles... então não seria proibido... não é um aborto assim... certamente... eles poderiam ter o ato e não estar matando o bebê... não tá sendo a criação de um bebê ainda..."

A aluna utilizou sua explicação sobre a forma de administração e ação da pílula do dia seguinte para justificar sua posição de não-proibição. No entanto, ela confundiu a pílula do dia seguinte com a pílula anticoncepcional, como fica evidente quando ela diz "ela pode tomar diariamente antes da gravidez ou quando ela quisesse", o que torna a sua argumentação inconsistente e falaciosa.

De acordo com Bell \& Lederman (2003), a integração de conhecimento científico equivocado pode ser simplesmente resultado da natureza instável das epistemologias mal-definidas dos respondentes. Assim como neste trabalho, os autores observaram que alguns participantes utilizam, na resolução de problemas sociocientíficos, valores pessoais em conjunção com entendimentos de ciência, enquanto outros utilizam valores pessoais ao invés de conteúdo científico.

Na tabela abaixo, estão todos os conceitos científicos que surgiram na discussão analisada, exceto aqueles que já eram explicitamente citados pelas questões propostas aos alunos. Assim, eles não constituem repetição de conceitos já dados, mas ideias trazidas pelos próprios alunos à discussão para legitimar ou conferir maior força aos seus argumentos. É evidente, nos enunciados onde encontramos conceitos científicos, a presença de valores associados ao argumento. A tabela mostra também quais os padrões morais e os valores associados aos argumentos ou asserções nos quais surgiram conceitos científicos, assim como a posição dos conceitos nos argumentos, o que nos 
permite analisar as relações entre conceitos científicos e padrões morais, valores e o papel de tal categoria na estrutura argumentativa.

Tabela 2: Conceitos científicos, padrões morais e valores. Posição dos conceitos nos argumentos.

\begin{tabular}{|c|c|c|c|c|c|}
\hline $\begin{array}{c}\text { Grupo/ } \\
\text { Enunciado }\end{array}$ & Trecho & Conceito(s) & Padrão Moral & Valor & $\frac{\underline{\text { Posicão do do }}}{\text { Conceito no }}$ \\
\hline B G28 & $\begin{array}{c}\text { \{eu acho que não é } \\
\text { um método } \\
\text { abortivo... } \mathrm{eu} \\
\text { também não acho... } \\
\frac{\text { eu acho que é um }}{\underline{\text { método }}} \\
\underline{\text { contraceptivo... um }} \\
\text { método que previne... }\end{array}$ & $\begin{array}{l}\text { Funcionamento } \\
\text { da Pílula do Dia } \\
\text { Seguinte, } \\
\text { Método } \\
\text { Contraceptivo }\end{array}$ & Deontológico & $\begin{array}{l}\text { Regras de } \\
\text { Decisão }\end{array}$ & $\underline{\text { Garantia/Apoio }}$ \\
\hline B R50 & $\begin{array}{l}\text { se o feto...se o feto... } \\
\text { se a mulher morrer o } \\
\frac{\text { feto vai morrer, mas }}{\text { se o feto morrer a }} \\
\frac{\text { mulher não vai }}{\text { morrer... }}\end{array}$ & $\begin{array}{l}\text { Interdependência } \\
\text { Funcional }\end{array}$ & Consequencialista & $\begin{array}{l}\text { Respeito ao } \\
\text { Valor da Vida }\end{array}$ & $\underline{\text { Dado }}$ \\
\hline C C56 & $\begin{array}{l}\text { eu acho que é assim } \\
\text { né, se por exemplo } \\
\text { ocorrer algo, é... risco } \\
\text { de vida... como hoje } \\
\text { existe já né é a mãe } \\
\frac{\text { de aluguel né... pegar }}{2 \text { o embrião e colocar }} \\
\text { em outra mãe...para } \\
\text { não ter esse problema }\end{array}$ & $\begin{array}{c}\text { Tecnologia } \\
\text { Médica ("barriga } \\
\text { de aluguel") }\end{array}$ & Consequencialista & $\begin{array}{l}\text { Respeito ao } \\
\text { Valor da Vida }\end{array}$ & $\underline{\text { Dado }}$ \\
\hline C P57 & $\begin{array}{c}\frac{\text { Não mas daí isso, isso }}{\text { pode acontecer }} \\
\frac{\text { quando o feto já está }}{\text { grande demais pra }} \\
\frac{\text { fazer essa... mãe de }}{\text { aluguel... }}\end{array}$ & $\begin{array}{c}\text { Tecnologia } \\
\text { Médica ("barriga } \\
\text { de aluguel") }\end{array}$ & Consequencialista & $\begin{array}{l}\text { Respeito ao } \\
\text { Valor da Vida }\end{array}$ & $\underline{\text { Refutador }}$ \\
\hline C W114 & $\begin{array}{l}\text { Eu acho que isso é um } \\
\text { método abortivo... } \\
\frac{\text { você tá impedindo }}{\text { que um ser se }} \\
\text { desenvolva... }\end{array}$ & $\begin{array}{c}\text { Desenvolvimento } \\
\text {, Funcionamento } \\
\text { da Pílula do Dia } \\
\text { Seguinte }\end{array}$ & Deontológico & $\begin{array}{l}\text { Respeito ao } \\
\text { Valor da Vida }\end{array}$ & $\underline{\text { Dado }}$ \\
\hline C P134 & $\begin{array}{c}\text { Não, desculpa, } \\
\text { deveria ser liberada... } \\
\text { a opinião do C... O C. } \\
\text { acha que... Né C. ó } \\
\text { se... isso daí não é um } \\
\text { aborto...você não tá } \\
\text { matando um ser... } \\
\frac{\text { você tá impedindo }}{\text { que ele se }} \\
\text { desenvolva... } \\
\text { impedindo... eu não } \\
\text { acho que é uma } \\
\text { técnica que deve ser } \\
\text { ilegal... }\end{array}$ & $\begin{array}{c}\text { Desenvolvimento } \\
\text {, Funcionamento } \\
\text { da Pílula do Dia } \\
\text { Seguinte }\end{array}$ & Deontológico & $\begin{array}{l}\text { Respeito ao } \\
\text { Valor da Vida }\end{array}$ & $\underline{\text { Dado }}$ \\
\hline C P142 & $\begin{array}{l}\text { \{Eu acho que deveria } \\
\text { tomar a pílula do dia } \\
\text { seguinte...\} Não, mas } \\
\text { e se já passou as } 72 \\
\end{array}$ & $\begin{array}{c}\text { Funcionamento } \\
\text { da Pílula do Dia } \\
\text { Seguinte }\end{array}$ & Intuitivo & $\begin{array}{l}\text { Regras de } \\
\text { Decisão }\end{array}$ & $\underline{\text { Refutador }}$ \\
\hline
\end{tabular}




\begin{tabular}{|c|c|c|c|c|c|}
\hline & horas... & & & & \\
\hline C C144 & $\begin{array}{c}\text { é... se não passou } \\
\text { essas } 72 \text { horas ela } \\
\text { ainda der tempo de } \\
\text { pegar a pílula... eu } \\
\text { acho que é esse } \\
\text { negócio né... tem que } \\
\text { deixar ele nascer né... } \\
\text { ninguém tem direito } \\
\text { de tirar a vida de um } \\
\text { humano... }\end{array}$ & $\begin{array}{c}\text { Funcionamento } \\
\text { da Pílula do Dia } \\
\text { Seguinte }\end{array}$ & Deontológico & $\begin{array}{l}\text { Respeito ao } \\
\text { Valor da Vida }\end{array}$ & Qualificador \\
\hline C P145 & $\begin{array}{c}\text { Aí ele já... aí se } \\
\text { depois das } 72 \text { horas } \\
\text { ele já se desenvolveu } \\
\text { daí eu acho que } \\
\text { ninguém tem direito } \\
\text { de fazer isso... }\end{array}$ & $\begin{array}{l}\text { Funcionamento } \\
\text { da Pílula do Dia } \\
\text { Seguinte }\end{array}$ & Deontológico & $\begin{array}{l}\text { Respeito ao } \\
\text { Valor da Vida }\end{array}$ & $\underline{\text { Dado }}$ \\
\hline D C12 & $\begin{array}{l}\text { não, mas é um filho } \\
\text { teu também, L., } \\
\text { mesmo assim, tem } \\
\text { seu óvulo lá... }\end{array}$ & Óvulo & Deontológico & $\begin{array}{l}\text { Valores } \\
\text { Familiares/ } \\
\text { Relacionais }\end{array}$ & $\underline{\text { Dado }}$ \\
\hline D L17 & $\begin{array}{l}\text { \{pra mim pílula do } \\
\text { dia seguinte também é } \\
\text { matar o seu filho...\} } \\
\text { Claro que não a pílula } \\
\underline{\text { do dia seguinte o }} \\
\frac{\text { embrião ainda nem se }}{\text { formou }}\end{array}$ & $\begin{array}{c}\text { Funcionamento } \\
\text { da Pílula do Dia } \\
\text { Seguinte }\end{array}$ & Deontológico & $\begin{array}{l}\text { Respeito ao } \\
\text { Valor da Vida }\end{array}$ & $\underline{\text { Dado }}$ \\
\hline D C24 & $\begin{array}{l}\text { \{uma pessoa que foi } \\
\text { estuprada ela não vai } \\
\text { ter que carregar o } \\
\text { filho do cara\} não } \\
\text { mas pensa assim, } \\
\text { mesmo assim, é um } \\
\text { filho seu, mesmo } \\
\text { sendo com uma } \\
\text { pessoa que você não } \\
\text { quer numa situação } \\
\text { inoportuna que } \\
\text { aconteceu é um filho } \\
\text { seu, vai ter seu gens } \\
\text { lá tem seu sangue lá } \\
\text { tem seu dna lá tem } \\
\text { seus óvulos lá... } \\
\text { mesmo você não } \\
\text { querendo é seu filho... }\end{array}$ & $\begin{array}{l}\text { Genes, Sangue, } \\
\text { DNA, Óvulos }\end{array}$ & $\begin{array}{c}\text { Deontológico, } \\
\text { Emotivo }\end{array}$ & $\begin{array}{l}\text { Valores } \\
\text { Familiares/ } \\
\text { Relacionais }\end{array}$ & $\underline{\text { Dado }}$ \\
\hline D B25 & $\begin{array}{l}\text { mas a pessoa não tá } \\
\text { preparada pra isso... } \\
\text { ainda não está } \\
\text { preparada... se for } \\
\text { uma menor de idade... } \\
\text { nossa idade mais ou } \\
\text { menos... ela não tá } \\
\text { preparada o corpo } \\
\text { físico e mental não tá } \\
\text { nada preparado... }\end{array}$ & $\begin{array}{l}\text { Maturidade } \\
\text { Sexual e } \\
\text { Gravidez }\end{array}$ & Consequencialista & $\begin{array}{c}\text { Riscos, } \\
\text { Acidentes e } \\
\text { Responsabilida } \\
\text { de }\end{array}$ & $\underline{\text { Dado }}$ \\
\hline D C34 & $\begin{array}{c}\text { professor, pensa } \\
\text { comigo... olha... tem } \\
\text { seus genes lá... é seu } \\
\text { filho do mesmo jeito... } \\
\text { filho do cara que te } \\
\text { estuprou e seu filho } \\
\text { também... }\end{array}$ & Genes & $\begin{array}{c}\text { Deontológico, } \\
\text { Emotivo }\end{array}$ & $\begin{array}{l}\text { Valores } \\
\text { Familiares/ } \\
\text { Relacionais }\end{array}$ & $\underline{\text { Dado }}$ \\
\hline
\end{tabular}




\begin{tabular}{|c|c|c|c|c|c|}
\hline D L35 & $\begin{array}{c}\text { claro que não... se } \\
\text { você abortar } 24 \text { horas } \\
\text { depois não é um } \\
\text { filho... ainda é um } \\
\text { embrião de nada... } \\
\text { nem um embrião... } \\
\text { nem se formou... }\end{array}$ & $\begin{array}{l}\text { Funcionamento } \\
\text { da Pílula do Dia } \\
\text { Seguinte, } \\
\text { Desenvolvimento } \\
\text { Embrionário }\end{array}$ & Deontológico & $\begin{array}{l}\text { Respeito ao } \\
\text { Valor da Vida }\end{array}$ & Qualificador \\
\hline D L37 B39 & $\begin{array}{l}\text { eu concordo com a } \\
\text { B., e se a menina tiver } \\
\underline{12 \text { anos... ela vai }} \\
\underline{\text { morrer no parto }}\end{array}$ & $\begin{array}{l}\text { Maturidade } \\
\text { Sexual e } \\
\text { Gravidez }\end{array}$ & Consequencialista & $\begin{array}{c}\text { Riscos, } \\
\text { Acidentes e } \\
\text { Responsabilida } \\
\text { de }\end{array}$ & $\frac{\text { Qualificador/ }}{\underline{\text { Conclusão }}}$ \\
\hline D C40 & $\begin{array}{c}\text { não B., não é } \\
\begin{array}{c}\text { necessariamente } \\
\text { morrer no parto... tem } \\
\text { muita criança hoje em }\end{array} \\
\frac{\text { dia que tem filho com }}{10 \ldots 10 \text { não, mas tipo }} \\
\frac{12,13,14 \text { anos que }}{\text { não morre no parto e }} \\
\text { tem o filho... }\end{array}$ & $\begin{array}{l}\text { Maturidade } \\
\text { Sexual e } \\
\text { Gravidez }\end{array}$ & Deontológico & $\begin{array}{c}\text { Riscos, } \\
\text { Acidentes e } \\
\text { Responsabilida } \\
\text { de }\end{array}$ & $\underline{\text { Dado }}$ \\
\hline D B41 & $\begin{array}{l}\text { mas eu tô falando } \\
\text { assim... mas você tem } \\
\text { risco de morrer... } \\
\frac{\text { você não deixa de ter }}{\text { risco... }}\end{array}$ & $\begin{array}{l}\text { Maturidade } \\
\text { Sexual e } \\
\text { Gravidez }\end{array}$ & Consequencialista & $\begin{array}{c}\text { Riscos, } \\
\text { Acidentes e } \\
\text { Responsabilida } \\
\text { de }\end{array}$ & $\underline{\text { Dado }}$ \\
\hline D L130 & $\begin{array}{c}\frac{\text { a pílula do dia }}{\text { seguinte são só depois }} \\
\frac{\text { de } 48 \text { horas... vocêe }}{\text { acha que depois de } 48} \\
\frac{\text { horas o zigoto vai se }}{\text { fixar no útero? }}\end{array}$ & $\begin{array}{l}\text { Funcionamento } \\
\text { da Pílula do Dia } \\
\text { Seguinte, } \\
\text { Desenvolvimento } \\
\text { Embrionário }\end{array}$ & Intuitivo & $\begin{array}{l}\text { Respeito ao } \\
\text { Valor da Vida }\end{array}$ & $\underline{\text { Conclusão }}$ \\
\hline D C131 & $\begin{array}{c}\frac{\text { sim, o professor disse }}{\text { que se fixa depois de }} \\
\text { 30 horas... ele fixa } \\
\text { depois de } 30 \text { horas... }\end{array}$ & $\begin{array}{l}\text { Desenvolvimento } \\
\text { Embrionário }\end{array}$ & Intuitivo & $\begin{array}{l}\text { Respeito ao } \\
\text { Valor da Vida }\end{array}$ & $\underline{\text { Conclusão }}$ \\
\hline E M99 & 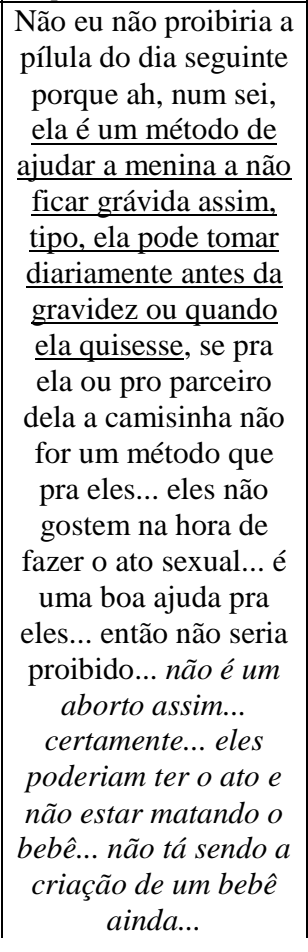 & $\begin{array}{l}\text { Funcionamento } \\
\text { da Pílula do Dia } \\
\text { Seguinte }\end{array}$ & Deontológico & $\begin{array}{c}\text { Regras de } \\
\text { Decisão, } \\
\text { Respeito ao } \\
\text { Valor da Vida }\end{array}$ & $\underline{\text { Dado }}$ \\
\hline
\end{tabular}


A relação entre os conceitos científicos e os valores e padrões morais é um tipo de dado relativamente inexplorado na literatura. Os conceitos científicos parecem ter a função de embasar os valores e conferir autoridade aos argumentos em que surgem.

É interessante notar que os conceitos científicos aparecem fortemente associados a três dos tipos de raciocínio informal - deontológico (utilização de princípios), consequencialista e intuitivo, enquanto a relação com a moral emotiva não é muito evidente, surgindo de forma tímida poucas vezes e, ainda assim, nunca sozinha, mas em conjunto com o raciocínio moral deontológico. Talvez os processos de utilização de justificativas conceituais e de empatia sejam, em algum nível, incompatíveis, ou talvez este resultado seja apenas reflexo de idiossincrasias dos sujeitos estudados.

A relação entre conceitos científicos e padrões morais racionalistas (deontológico e consequencialista) já era, de certa forma, esperada, já que tais padrões se caracterizam pela proposição de justificativas baseadas na razão, o que torna tais categorias bastante compatíveis com a presença de conceitos científicos.

Já no que diz respeito à moral intuitiva, o resultado parece chamar mais atenção. O que levaria os alunos a utilizarem conceitos científicos associados a padrões morais intuitivos algumas vezes? Talvez isso se deva simplesmente ao fato de a moral intuitiva ser o padrão moral mais abundante na discussão. Outra interpretação possível é de que o aluno realmente veja o conceito científico como um elemento que confere maior autoridade à afirmação, abrindo mão, assim, em boa parte dos casos, dos dados que serviriam de suporte à conclusão.

Podemos aqui fazer um paralelo com a ideia de Haidt (2001), que propõe uma sequência, ou um mecanismo, para as escolhas morais das pessoas, que não necessariamente são guiadas pela razão. Segundo o autor, as pessoas geralmente tomam decisões intuitivas, que são baseadas em valores, e depois buscam uma explicação racional (Raciocínio Moral Deontológico ou Consequencialista) para suportar sua decisão. Neste trabalho não foi observada exatamente tal sequência, já que a moral intuitiva nem sempre é seguida de explicações racionais ou com conceitos científicos no decorrer das interações. De fato, o presente trabalho nem poderia representar um teste para a teoria de Haidt, já que não há exatamente momentos de decisões individuais, mas decisões conjuntas e mudanças de opinião ao longo da interação. Além disso, as decisões e as formas de pensamento de alguns indivíduos provavelmente acabam "mascaradas" pelo grupo, por questões de dinâmica dos grupos. 
Mesmo assim, a associação dos conceitos científicos com os padrões morais deontológico, consequencialista e intuitivo pode indicar algo próximo à ideia de Haidt, ou seja, os conceitos podem estar sendo invocados para embasar os valores presentes na maioria dos argumentos e as posições não justificadas representadas pela moral intuitiva.

O gráfico abaixo, produzido a partir da tabela 2, mostra, em termos proporcionais, a relação entre os conceitos científicos e os padrões morais analisados neste trabalho.

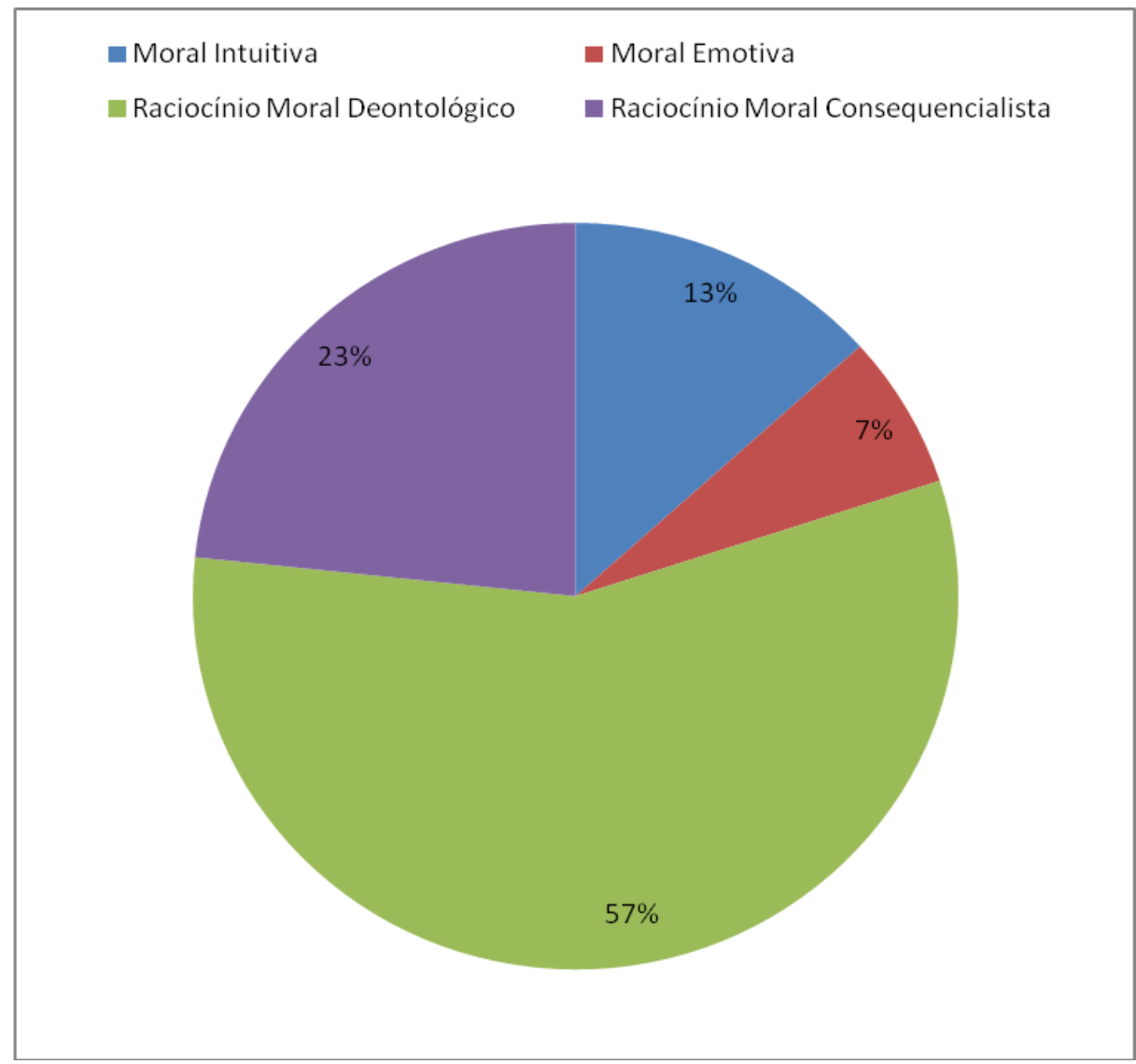

Figura 4: Padrões morais presentes nos enunciados contendo conceitos científicos.

No que se refere a valores associados aos conceitos, foram muito comuns os valores de respeito ao valor da vida. O gráfico abaixo relaciona os conceitos científicos com os grupos de valores e crenças presentes na discussão. 


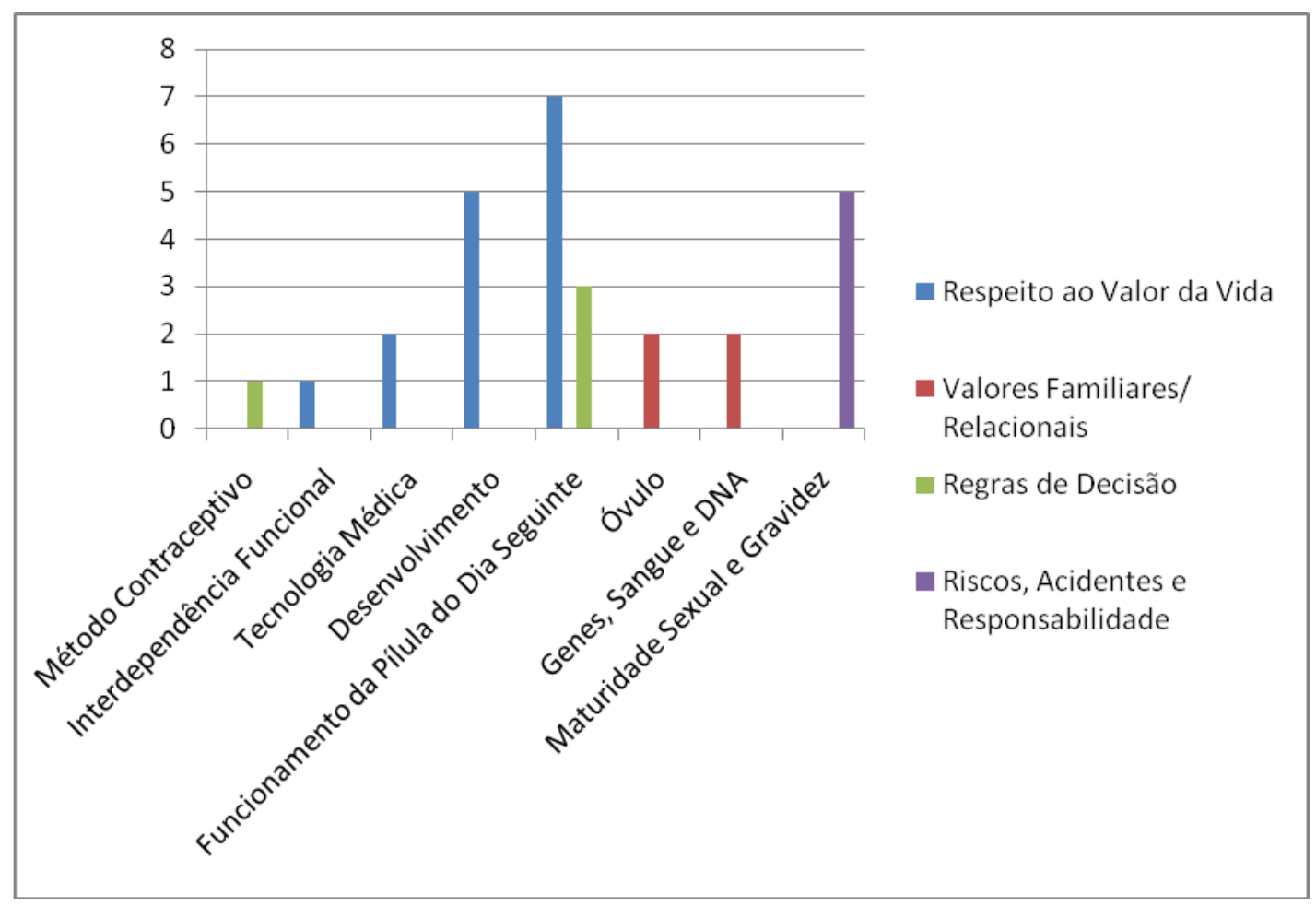

Figura 5: Número de vezes em que os conceitos científicos surgiram associados a cada grupo de valores.

Como se pode notar, há uma forte tendência ao surgimento de conceitos científicos associados ao grupo do respeito ao valor da vida, valores que assumiam um valor absoluto da vida ou sua relativização, como no caso abaixo, em que o aluno defendia a utilização da pílula do dia seguinte apenas até um certo limite de tempo após a concepção:

Grupo C, P145: “Aí ele já... aí se depois das 72 horas ele já se desenvolveu daí eu acho que ninguém tem direito de fazer isso..."

O conceito está presente nas considerações sobre o tempo necessário para ocorrer a nidação e o tempo de ação da pílula do dia seguinte. $\mathrm{O}$ valor de respeito à vida está implícito quando o aluno diz “... ninguém tem direito de fazer isso...”.

Os motivos que levam ao maior surgimento de conceitos científicos associados a esses tipos de valores não podem ser respondidos com certeza por este trabalho, mas podem estar relacionados à natureza das proposições com esses tipos de valores ou ainda aos valores pessoais dos sujeitos que mais utilizaram conceitos em sua argumentação. 
Um dos resultados mais interessantes se refere às posições ocupadas pelos conceitos científicos e pelos valores nos argumentos. O gráfico abaixo mostra o número de vezes em que os conceitos surgiam nas diferentes posições dos argumentos.

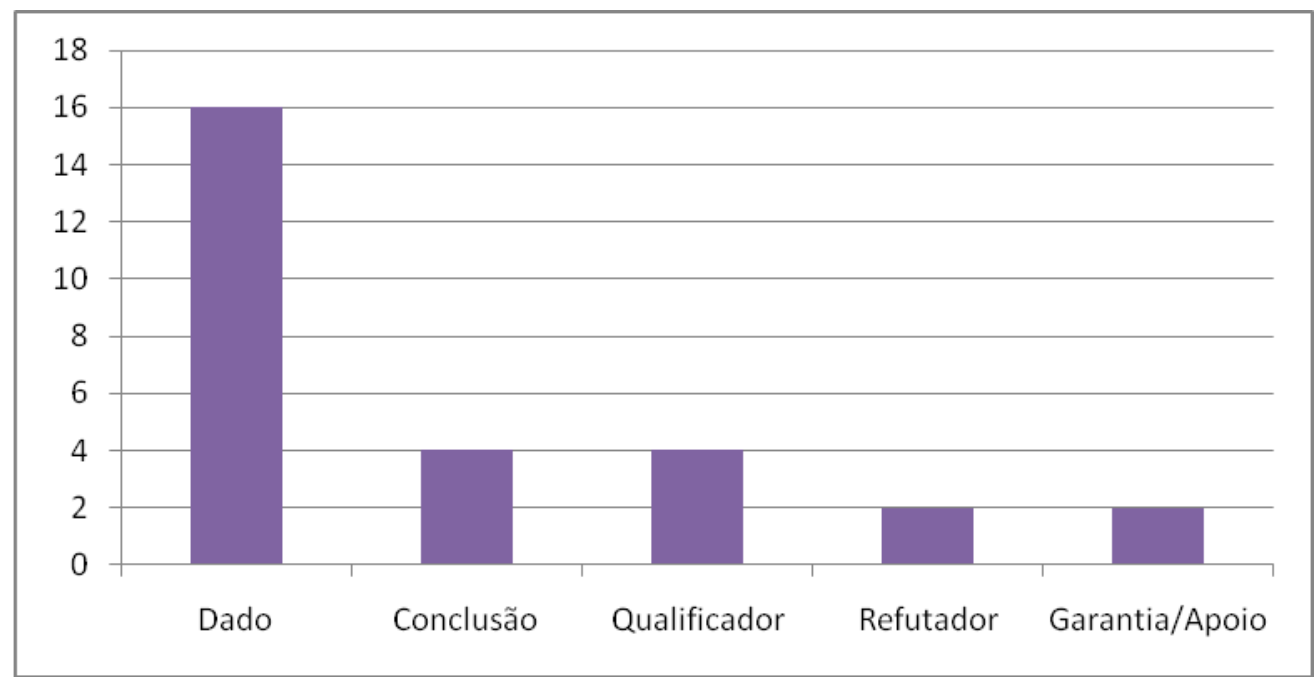

Figura 6: Posições dos conceitos científicos nos argumentos - número de ocorrências.

Os conceitos científicos apareceram majoritariamente na posição de dado dos argumentos, aparecendo também nas posições de refutador, qualificador, conclusão e até na posição onde esperaríamos encontrar a garantia, ou seja, servindo de ligação entre o dado e a conclusão. A utilização do conceito científico nessa posição foi observada apenas uma vez, no seguinte argumento:

Grupo B, G28: "Eu também não acho [que a pílula do dia seguinte é um método abortivo]... eu acho que é um método contraceptivo... um método que previne..."

Aqui, temos um argumento que poderia ser montado da seguinte forma, segundo o Padrão de Toulmin:

DADO QUE [a pílula do dia seguinte] é um método que previne, JÁ QUE eu acho que [ela] é um método contraceptivo, ENTÃO eu também não acho [que a pílula do dia seguinte é um método abortivo]. 
Lembrando que as garantias são, segundo Toulmin (2003), de natureza mais geral que os dados, não é provável que possamos interpretar a parte que contém o conceito "método contraceptivo" como sendo o dado, já que quando a aluna diz "é um método que previne" ela está explicando o conceito, o que pode ser considerado mais específico e, portanto, fazendo parte do dado. Na verdade, parece mais plausível que o conceito "método contraceptivo" represente o apoio do argumento, ao invés da garantia, trazendo à tona o conhecimento de referência sobre o qual o argumento se baseia. De acordo com o autor, há argumentos compostos de dado, apoio e conclusão, que também podem ser apresentados em forma lógica válida, além dos clássicos argumentos formados de dado, garantia e conclusão.

Se considerarmos o conceito acima como representando o apoio do argumento, não há, no total dos argumentos analisados, conceitos científicos na posição de garantias. Parece razoável também afirmar que, quando os conceitos surgem fazendo a ligação entre dados e conclusão, há grandes chances de que eles representem o apoio e não a garantia do argumento. Segundo o próprio Toulmin (2003): “...o apoio para as garantias pode ser expresso na forma de afirmações categóricas de fato...” (p. 151).

E, realmente, quando alguém diz que tal método é um método contraceptivo, ou utiliza algum outro conceito científico em uma proposição, isso pode ser tomado como uma afirmação categórica de fato, e não uma hipótese.

Outro alerta deve ser feito nesse mesmo caso, pois o conhecimento sobre o qual o argumento se baseia não está necessariamente correto. É sabido que a pílula do dia seguinte age impedindo a fecundação ou, caso esta já tenha ocorrido, impedindo a implantação do zigoto no útero. Assim, chamar a pílula do dia seguinte de método contraceptivo é discutível, principalmente se considerarmos concepção como equivalente a fecundação. De qualquer forma, não podemos ignorar que a pílula do dia seguinte é classificada como "contracepção de emergência" até entre médicos e cientistas da área.

A maior ocorrência de conceitos científicos na posição de dado é coerente com o esperado, já que os dados representam os suportes das alegações. Isso também é evidência da função que os conceitos desempenham nessa discussão, como elementos que conferem autoridade e embasamento às opiniões carregadas de valores. Os resultados mostram que os conceitos também podem ser utilizados, no sentido de conferir maior autoridade, em posições que limitam e qualificam a conclusão, que 
refutam um outro argumento ou que realçam uma posição ou decisão (no caso da conclusão), além da possibilidade de utilização para apoiar uma garantia.

Se observarmos as tabelas contendo os argumentos dos cinco grupos, constataremos que a utilização de conceitos não é uma regra na discussão do tema sociocientífico aborto com alunos desta faixa etária. Assim, os resultados deste trabalho corroboram e complementam os resultados de outros autores da área, que afirmam que as tomadas de decisões dos alunos são predominantemente movidas pelo domínio afetivo e não por conhecimento do conteúdo científico (WALKER \& ZEIDLER, 2007).

As pesquisas sobre questões sociocientíficas geralmente não mostram evidências de relação entre diferentes níveis de conhecimento de conteúdo e tendências diferenciais do uso de padrões de raciocínio informal (SADLER \& ZEIDLER, 2005). Há, no entanto, dados como os de Sadler \& Fowler, (2006) segundo os quais indivíduos com melhores conhecimentos de genética mostraram padrões diferentes em termos de como eles usavam o conhecimento de conteúdo biológico específico para suportar suas posições.

Aqui não temos dados sobre o conhecimento do conteúdo associado de cada um dos alunos participantes da discussão, mas se tomarmos como base a conclusão do trabalho citado acima, poderemos inferir que, provavelmente, aqueles alunos que melhor integraram os conceitos científicos com os valores apresentavam um melhor domínio sobre os aspectos conceituais do tema.

\subsection{Valores: Funções no Argumento e Relações com Padrões Morais}

Enquanto os conceitos científicos, no contexto da análise dos argumentos segundo o Padrão de Toulmin (2003), exerciam principalmente a função de dado, os valores presentes nos argumentos possuidores de conceitos científicos exerciam, principalmente, a função de garantias, permitindo a ligação entre os dados e as conclusões. Essa função dos valores nos argumentos já havia sido prevista por Kolsto (2006), que, em sua análise de estudantes defendendo suas posições sobre o impacto de instalações elétricas na saúde pública, utilizou o padrão de Toulmin para acessar os valores dos sujeitos, através das garantias. Na análise de Kolsto, os valores sempre representavam as garantias dos argumentos. 
Uma diferença importante entre este trabalho e o de Kolsto é que ele analisou as falas dos estudantes como grandes argumentos, ou "macroargumentos" - segundo definição de Toulmin - e, a partir daí, inferiu os valores que lhes serviriam como garantias. As garantias eram produzidas a partir de várias falas analisadas das entrevistas. Neste trabalho, os argumentos individuais ou "microargumentos" são analisados, e os valores representaram garantias ou outras funções do Padrão de Toulmin para cada um desses argumentos. A origem dos dados aqui também é diferente, já que são analisadas as falas dos estudantes em uma discussão em grupo, o que pode explicar parte da diferença em termos de diversidade de valores entre os dois trabalhos.

A tabela abaixo mostra os valores presentes nos argumentos e asserções mostrados na tabela 2 , além das posições de tais valores nos argumentos.

Tabela 3: Valores utilizados nos enunciados contendo conceitos científicos. Posições dos valores nos argumentos, de acordo com o modelo de Toulmin (2003).

\begin{tabular}{|c|c|c|c|}
\hline $\begin{array}{l}\text { Grupo/ } \\
\text { Enunciado }\end{array}$ & Trecho & Valor & $\begin{array}{l}\text { Posição do } \\
\text { Valor no } \\
\text { Argumento } \\
\end{array}$ \\
\hline B G28 & $\begin{array}{l}\text { \{eu acho que não é um método abortivo...\} eu } \\
\text { também não acho... eu acho que é um método } \\
\text { contraceptivo... um método que previne... }\end{array}$ & $\begin{array}{l}\text { Regras de } \\
\text { Decisão }\end{array}$ & Conclusão \\
\hline B R50 & $\begin{array}{l}\text { se o feto...se o feto... se a mulher morrer o feto } \\
\frac{\text { vai morrer, mas se o feto morrer a mulher não }}{\text { vai morrer... }}\end{array}$ & $\begin{array}{l}\text { Respeito ao } \\
\text { Valor da Vida }\end{array}$ & Garantia \\
\hline C C56 & $\begin{array}{l}\text { eu acho que é assim né, se por exemplo ocorrer } \\
\text { algo, é... risco de vida... como hoje existe já né é } \\
\frac{\text { a mãe de aluguel né... pegar o embrião e colocar }}{\text { em outra mãe...para não ter esse problema }}\end{array}$ & $\begin{array}{l}\text { Respeito ao } \\
\text { Valor da Vida }\end{array}$ & Garantia \\
\hline C P57 & $\begin{array}{l}\frac{\text { Não mas daí isso, isso pode acontecer quando o }}{\text { feto já está grande demais pra fazer essa... mãe }} \\
\underline{\text { de aluguel... }}\end{array}$ & $\begin{array}{l}\text { Respeito ao } \\
\text { Valor da Vida }\end{array}$ & Garantia \\
\hline C W114 & $\begin{array}{l}\text { Eu acho que isso é um método abortivo... você tá } \\
\text { impedindo que um ser se desenvolva... }\end{array}$ & $\begin{array}{l}\text { Respeito ao } \\
\text { Valor da Vida }\end{array}$ & Garantia \\
\hline C P134 & 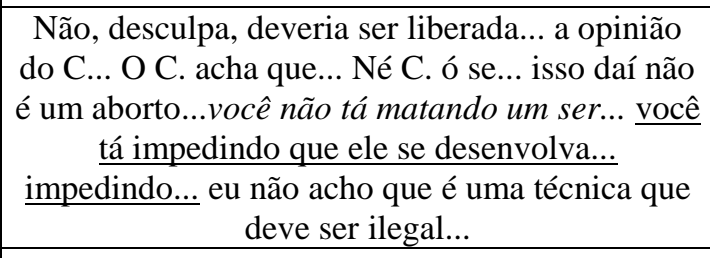 & $\begin{array}{l}\text { Respeito ao } \\
\text { Valor da Vida }\end{array}$ & Garantia \\
\hline C P142 & $\begin{array}{l}\text { \{Eu acho que deveria tomar a pílula do dia } \\
\text { seguinte... } \frac{\text { Não, mas e se já passou as } 72}{\underline{\text { horas... }}}\end{array}$ & $\begin{array}{l}\text { Regras de } \\
\text { Decisão }\end{array}$ & Refutador \\
\hline
\end{tabular}




\begin{tabular}{|c|c|c|c|}
\hline C C144 & $\begin{array}{c}\text { é... se não passou essas } 72 \text { horas ela ainda der } \\
\text { tempo de pegar a pílula... eu acho que é esse } \\
\text { negócio né... tem que deixar ele nascer né... } \\
\text { ninguém tem direito de tirar a vida de um } \\
\text { humano... }\end{array}$ & $\begin{array}{l}\text { Respeito ao } \\
\text { Valor da Vida }\end{array}$ & Dado \\
\hline C P145 & $\begin{array}{l}\text { Aí ele já... aí se depois das } 72 \text { horas ele já se } \\
\frac{\text { desenvolveu daí eu acho que ninguém tem }}{\text { direito de fazer isso... }}\end{array}$ & $\begin{array}{l}\text { Respeito ao } \\
\text { Valor da Vida }\end{array}$ & Conclusão \\
\hline D C12 & $\begin{array}{c}\text { não, mas é um filho teu também, L., mesmo } \\
\text { assim, tem seu óvulo lá... }\end{array}$ & $\begin{array}{c}\text { Valores } \\
\text { Familiares/ } \\
\text { Relacionais }\end{array}$ & Garantia \\
\hline D L17 & $\begin{array}{l}\text { \{pra mim pílula do dia seguinte também é matar } \\
\text { o seu filho...\} Claro que não a pílula do dia } \\
\text { seguinte o embrião ainda nem se formou }\end{array}$ & $\begin{array}{l}\text { Respeito ao } \\
\text { Valor da Vida }\end{array}$ & Garantia \\
\hline D C24 & $\begin{array}{l}\text { \{uma pessoa que foi estuprada ela não vai ter que } \\
\text { carregar o filho do cara }\} \text { não mas pensa assim, } \\
\text { mesmo assim, é um filho seu, mesmo sendo com } \\
\text { uma pessoa que você não quer numa situação } \\
\text { inoportuna que aconteceu é um filho seu, vai ter } \\
\text { seu gens lá tem seu sangue lá tem seu dna lá tem } \\
\text { seus óvulos lá... mesmo você não querendo é seu } \\
\text { filho... }\end{array}$ & $\begin{array}{l}\text { Valores } \\
\text { Familiares/ } \\
\text { Relacionais }\end{array}$ & Garantia \\
\hline D B25 & $\begin{array}{l}\text { mas a pessoa não tá preparada pra isso... ainda } \\
\text { não está preparada... se for uma menor de idade... } \\
\begin{array}{c}\text { nossa idade mais ou menos... ela não tá } \\
\text { preparada o corpo físico e mental não tá nada } \\
\text { preparado... }\end{array}\end{array}$ & $\begin{array}{c}\text { Riscos, } \\
\text { Acidentes e } \\
\text { Responsabilidade }\end{array}$ & Garantia \\
\hline D C34 & $\begin{array}{l}\text { professor, pensa comigo... olha... tem seus genes } \\
\text { lá... é seu filho do mesmo jeito... filho do cara } \\
\text { que te estuprou e seu filho também... }\end{array}$ & $\begin{array}{l}\text { Valores } \\
\text { Familiares/ } \\
\text { Relacionais }\end{array}$ & Conclusão \\
\hline D L35 & $\begin{array}{c}\text { claro que não... se você abortar } 24 \text { horas depois } \\
\text { não é um filho... ainda é um embrião de nada... } \\
\text { nem um embrião... nem se formou... }\end{array}$ & $\begin{array}{l}\text { Respeito ao } \\
\text { Valor da Vida }\end{array}$ & Garantia \\
\hline D L37 B39 & $\begin{array}{l}\text { eu concordo com a B., e se a menina tiver } 12 \\
\underline{\text { anos... ela vai morrer no parto }}\end{array}$ & $\begin{array}{c}\text { Riscos, } \\
\text { Acidentes e } \\
\text { Responsabilidade }\end{array}$ & Garantia \\
\hline D C40 & $\begin{array}{l}\text { não B., não é necessariamente morrer no parto... } \\
\frac{\text { tem muita criança hoje em dia que tem filho com }}{\frac{10 \ldots 10 \text { não, mas tipo } 12,13,14 \text { anos que não }}{\text { morre no parto e tem o filho... }}}\end{array}$ & $\begin{array}{c}\text { Riscos, } \\
\text { Acidentes e } \\
\text { Responsabilidade }\end{array}$ & Garantia \\
\hline D B41 & $\begin{array}{l}\text { mas eu tô falando assim... mas você tem risco de } \\
\text { morrer... você não deixa de ter risco... }\end{array}$ & $\begin{array}{c}\text { Riscos, } \\
\text { Acidentes e } \\
\text { Responsabilidade } \\
\end{array}$ & Garantia \\
\hline D L130 & $\frac{\frac{\text { a pílula do dia seguinte são só depois de } 48}{\text { horas... você acha que depois de } 48 \text { horas o }}}{\text { zigoto vai se fixar no útero? }}$ & $\begin{array}{l}\text { Respeito ao } \\
\text { Valor da Vida }\end{array}$ & Conclusão \\
\hline D C131 & $\frac{\text { sim, o professor disse que se fixa depois de } 30}{\text { horas... ele fixa depois de } 30 \text { horas... }}$ & $\begin{array}{l}\text { Respeito ao } \\
\text { Valor da Vida }\end{array}$ & Conclusão \\
\hline
\end{tabular}


Não eu não proibiria a pílula do dia seguinte porque ah, num sei, ela é um método de ajudar a menina a não ficar grávida assim, tipo, ela pode tomar diariamente antes da gravidez ou quando ela quisesse, se pra ela ou pro parceiro dela a camisinha não for um método que pra eles... eles não gostem na hora de fazer o ato sexual... é uma boa ajuda pra eles... então não seria proibido... não é um aborto assim... certamente... eles poderiam ter o ato e não estar matando o bebê... não tá sendo a criação de um bebê ainda...
Regras de

Decisão,

Respeito ao Valor da Vida
Garantia

A figura 7 mostra como, nos enunciados da tabela acima, variaram as posições dos valores nos argumentos.

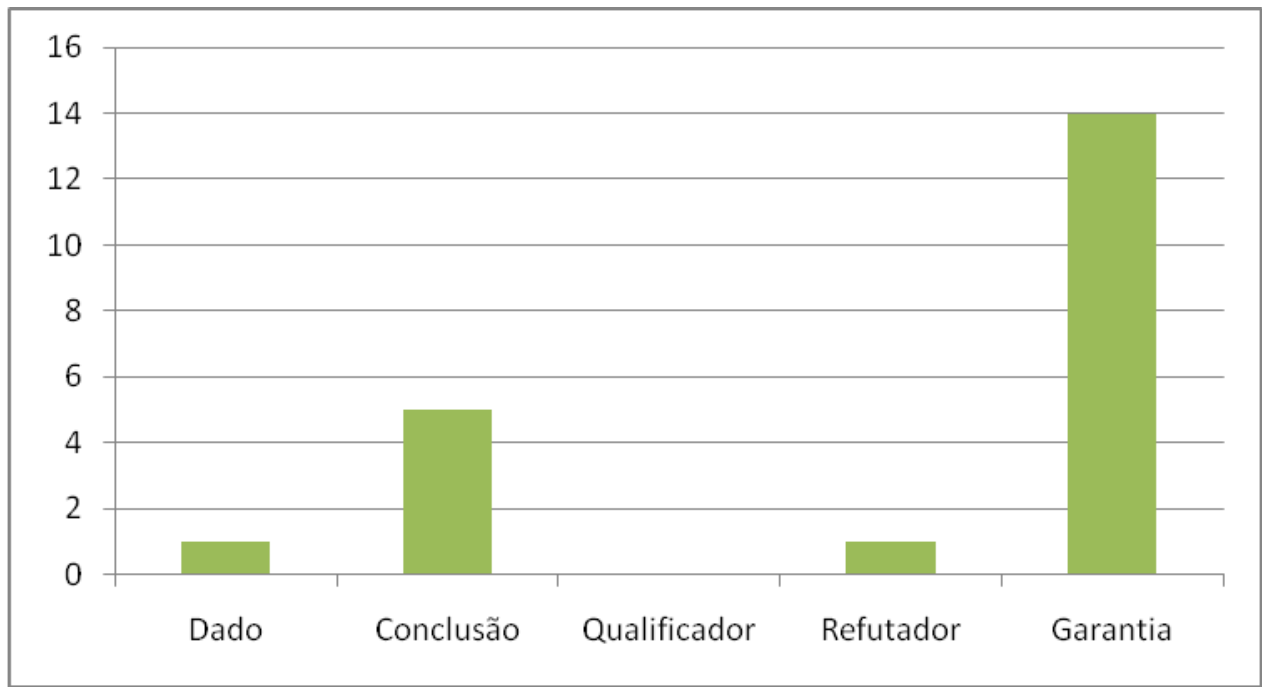

Figura 7: Funções dos valores, segundo os elementos do padrão de argumentação de Toulmin (2003), nos enunciados que contêm conceitos científicos.

Aqui podemos explorar uma nova possibilidade de interpretação das funções dos valores nos argumentos, já que os valores também aparecem nas posições de conclusão, refutador e dado, além da já esperada função de garantia. Assim, além de exercer a função de ligação entre dados e conclusões, os valores também podiam estar implícitos ou explícitos nas conclusões, podiam ser usados para refutar outro argumento e até servir como suporte para um argumento. $\mathrm{O}$ enunciado no qual o valor apresenta função de dado é o seguinte:

Grupo C, C144: “é... se não passou essas 72 horas ela ainda der tempo de pegar a pílula... eu acho que é esse negócio né... tem que deixar ele nascer né... ninguém tem direito de tirar a vida de um humano..." 
Aqui temos um argumento e um qualificador de outra conclusão misturados, que poderiam ser escritos da seguinte forma, utilizando o Padrão de Toulmin:

SE não passou essas 72 horas e SE ela ainda der tempo de pegar a pílula, [ENTÃO ela deve tomar a pílula.]

[SE já passaram as 72 horas], DADO QUE ninguém tem direito de tirar a vida de um humano, ENTÃO tem que deixar ele nascer.

As partes iniciadas por "SE" representam os qualificadores do argumento e da conclusão implícita na fala do aluno. "DADO QUE" inicia o dado, enquanto "ENTÃO" é marcador de conclusão. Nesse caso, quando o sujeito diz que "ninguém tem direito de tirar a vida de um humano", está claramente usando um valor pessoal, o de respeito à vida, para fundamentar seu argumento. Talvez o uso do valor como dado aqui se dê em função do caráter geral que apresenta esse valor. Assim, o fato de o valor de respeito à vida ser bastante aceito pela maioria das pessoas poderia explicar a força que o aluno o credita, já que o utilizou como suporte do argumento.

As freqüências de surgimento dos valores também são dados interessantes que merecem considerações. No gráfico seguinte, observamos o número de vezes em que cada valor surgiu na discussão sobre o aborto. 


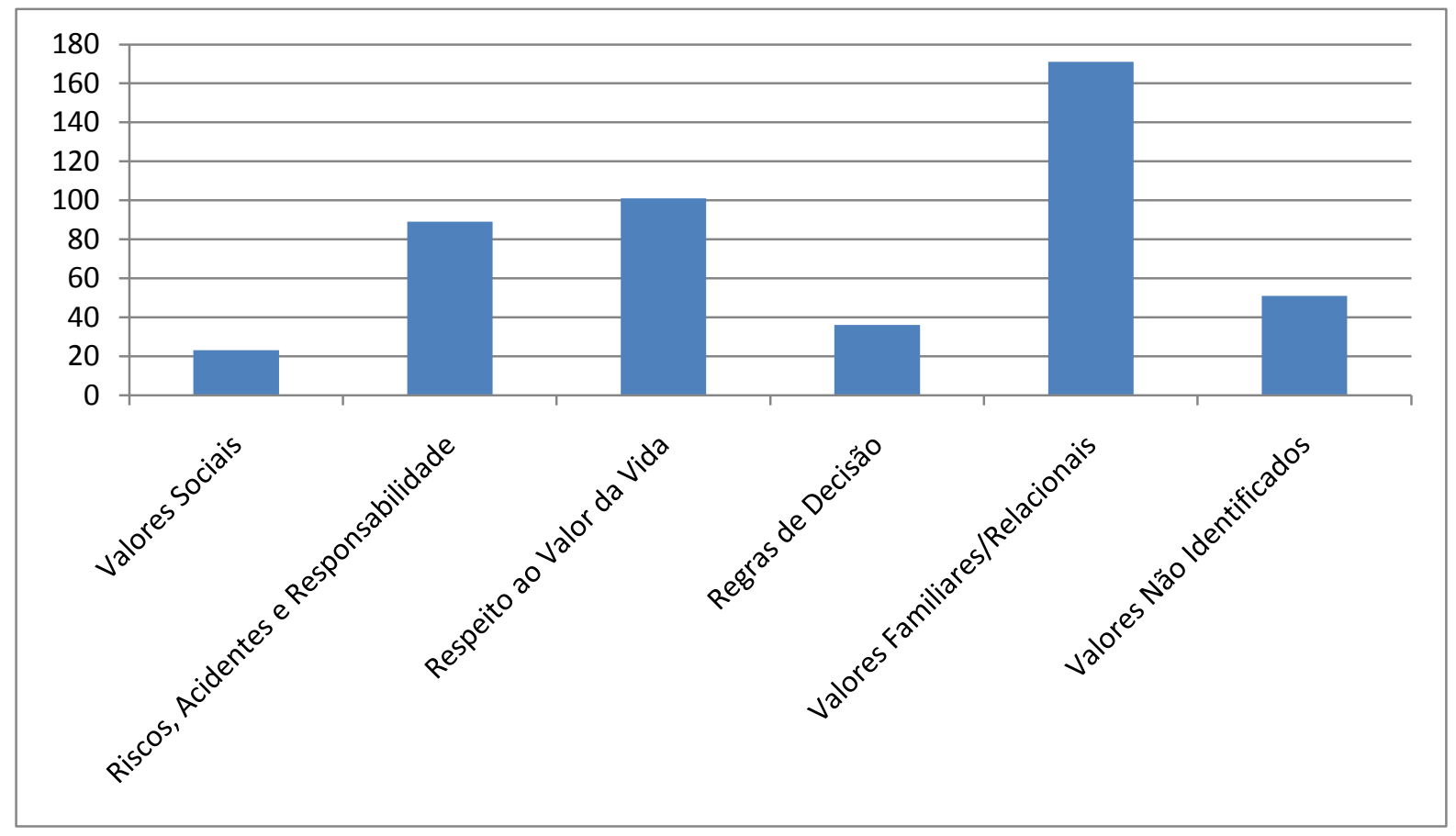

Figura 8: Número de vezes em que os diferentes tipos de valores surgiram na discussão sociocientífica sobre o aborto.

Algumas tendências importantes merecem destaque no gráfico acima. Podemos notar, por exemplo, que, de todos os valores, os mais comuns na discussão sobre o aborto foram aqueles chamados aqui de valores familiares ou relacionais. Isso se deve a vários fatores. Uma das razões pode ser o fato de pelo menos três das questões (3, 4 e 8) propostas aos estudantes estarem relacionadas a decisões familiares e relacionais. $\mathrm{O}$ próprio tema do aborto também pode ter suscitado maior utilização desse tipo de valores, pela natureza do assunto. Outra possibilidade é que os alunos apenas estejam reproduzindo os valores mais comuns entre seus pais.

Os valores menos comuns foram os chamados valores sociais e as regras de decisão. Novamente, talvez estejamos diante de um reflexo dos valores dos adultos da classe média alta da cidade de São Paulo. Talvez tais valores não fossem muito familiares para os alunos. No caso dos valores sociais, ou seja, aqueles que consideravam que as decisões sobre o aborto podiam estar relacionadas ao bem estar coletivo, se pensarmos sob a perspectiva das ideias de Kohlberg, é possível também que boa parte dos alunos ainda não tenham atingido o nível de desenvolvimento moral necessário para que considerassem a ordem social e os direitos universais como valores importantes. 
Para explicar o número de vezes em que surgiram valores do tipo regras de decisão, podemos pensar que tais valores não tinham nenhuma especificidade ou relação necessária com a questão do aborto, podendo ser utilizados para resolver qualquer outro tipo de questão. Essa falta de conexão poderia ser uma causa para o número reduzido de vezes em que encontramos esses valores na discussão analisada.

Além de apresentarem funções importantes na estrutura dos argumentos e no conteúdo de discussões sociocientíficas, os valores apresentaram distribuições preferenciais de acordo com os padrões morais analisados. Assim, podemos inferir que os valores de cuidado e os valores de justiça também não se distribuem homogeneamente pelas categorias de padrões morais.

Aqui podemos traçar uma relação entre as ideias de Gilligan e as categorias de padrões morais, já que os valores que surgiram exclusivamente associados à ética da justiça (vide tabela 1), ou seja, ligados aos ideais de certo e errado, direitos e obrigações, equidade e reciprocidade, também eram exclusivamente associados ao padrão moral deontológico (raciocínio baseado em princípios). Parece, então, haver uma correlação, não necessária, mas preferencial, entre ética da justiça e raciocínio moral deontológico, e ética do cuidado e padrões morais emotivo e racionalista consequencialista. Esse fato pode estar relacionado à própria natureza dessas duas linguagens morais, ou então ao uso preferencial da ética da justiça ou do cuidado na discussão em função de vários fatores, como familiaridade com um ou outro tipo de abordagem ou utilização das linguagens morais segundo o que se acredita ser esperado. Assim, pode ser que os alunos escolhem o tipo de linguagem moral de acordo com o que eles percebem que são as expectativas do professor.

A tabela e o gráfico abaixo nos mostram a distribuição dos valores pelas categorias de padrões morais em termos absolutos. 
Tabela 4: Número de ocorrências dos grupos de valores e dos padrões morais na discussão sobre o aborto.

\begin{tabular}{|c|c|c|c|c|c|}
\hline $\begin{array}{l}\text { Grupos de } \\
\text { Valores }\end{array}$ & $\begin{array}{c}\text { Moral } \\
\text { Intuitiva }\end{array}$ & $\begin{array}{c}\text { Moral } \\
\text { Emotiva }\end{array}$ & $\begin{array}{c}\text { Raciocínio } \\
\text { Moral } \\
\text { Deontológico }\end{array}$ & $\begin{array}{l}\text { Raciocínio Moral } \\
\text { Consequencialista }\end{array}$ & Total \\
\hline Valores Sociais & 3 & 2 & 7 & 11 & 23 \\
\hline $\begin{array}{c}\text { Riscos, Acidentes } \\
e \\
\text { Responsabilidade }\end{array}$ & 38 & 13 & 36 & 5 & 92 \\
\hline $\begin{array}{c}\text { Respeito ao } \\
\text { Valor da Vida }\end{array}$ & 35 & 5 & 48 & 13 & 101 \\
\hline $\begin{array}{l}\text { Regras de } \\
\text { Decisão }\end{array}$ & 6 & 1 & 26 & 0 & 33 \\
\hline $\begin{array}{c}\text { Valores } \\
\text { Familiares/ } \\
\text { Relacionais }\end{array}$ & 71 & 34 & 16 & 50 & 171 \\
\hline $\begin{array}{l}\text { Valores Não } \\
\text { Identificados }\end{array}$ & 51 & 0 & 0 & 0 & 52 \\
\hline Total & 204 & 55 & 133 & 79 & 471 \\
\hline
\end{tabular}

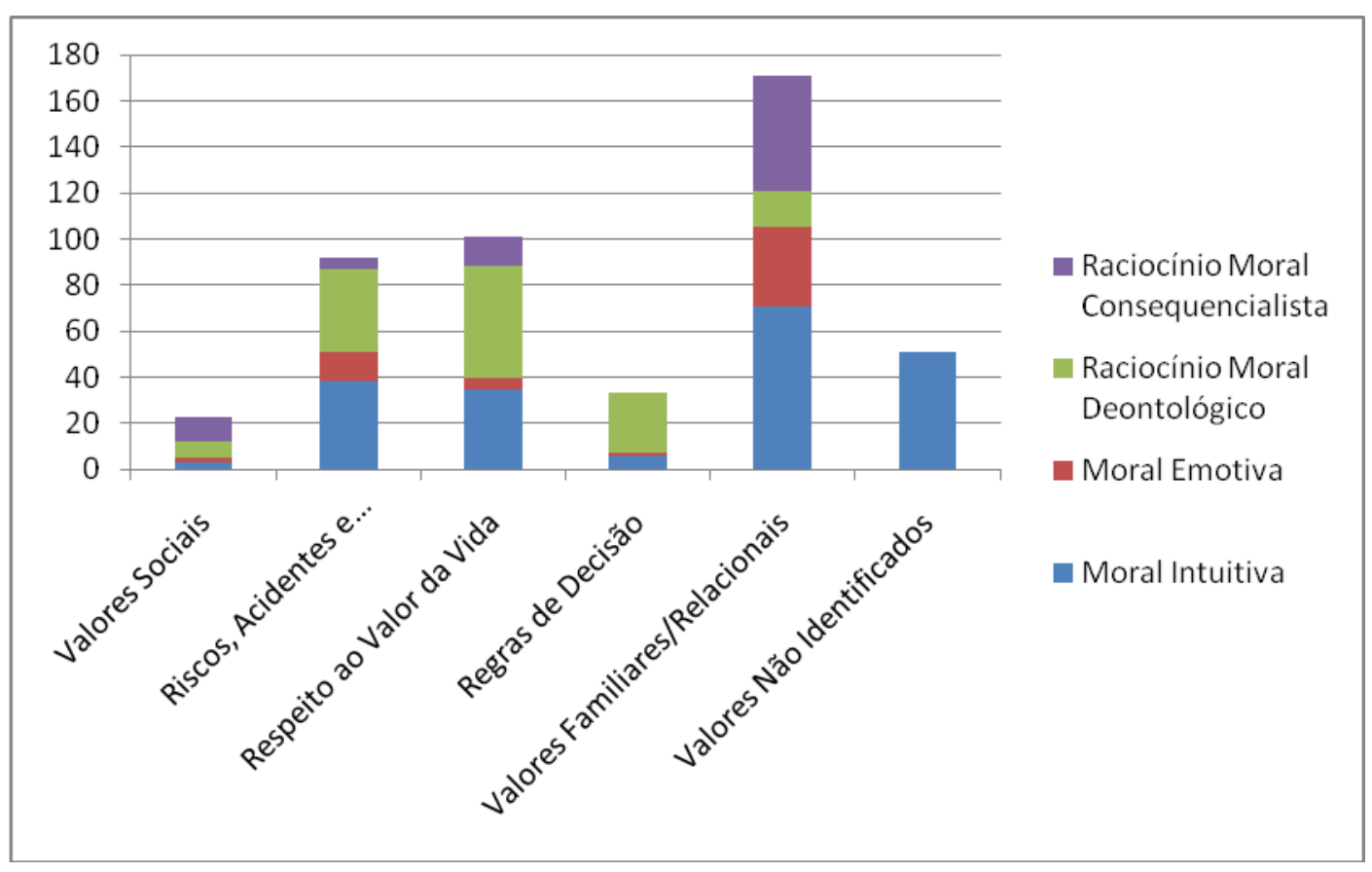

Figura 9: Os padrões morais associados aos valores - número de ocorrências.

O gráfico seguinte mostra a mesma relação entre valores e padrões morais, mas em termos relativos: 


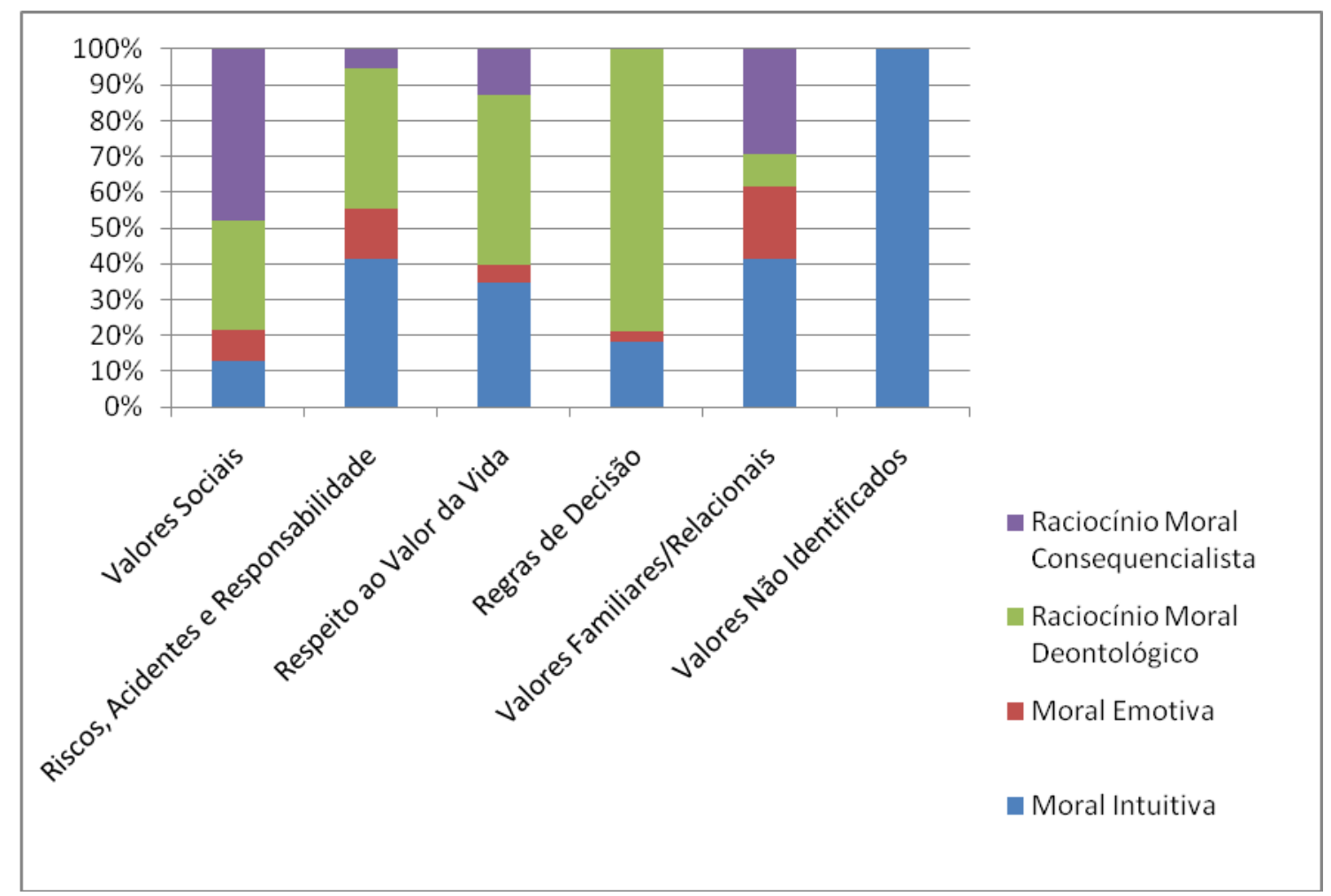

Figura 10: Padrões morais associados aos valores, em termos relativos.

Aqui podemos nos deter a analisar mais detalhadamente a relação entre cada valor e cada padrão moral. Podemos iniciar com os valores mais comuns, ou seja, os valores familiares/relacionais. Esses valores apresentaram-se muito mais relacionados aos padrões morais consequencialista e emotivo que ao padrão deontológico (raciocínio moral baseado em princípios). Tal resultado deve-se, em grande parte, à natureza de tais valores, que podem ser associados à linguagem ética do cuidado, dentro do paradigma proposto por Carol Gilligan. No contexto da ética do cuidado, os ideais valorizados são a conexão, o amor, a responsividade, a manutenção de relacionamentos, a interdependência, a compaixão, a capacidade de assumir a perspectiva alheia, a responsabilidade e a preocupação com os outros. Tais ideais estão presentes nos valores classificados neste trabalho como valores familiares: implicações para a vida da mãe, planejamento familiar, cuidado extra-familiar, cuidado parental, manutenção de relações, ambição e segurança financeira. Da mesma forma, esses ideais se aproximam da lógica do padrão moral emotivo, pelo valor da empatia e da compaixão. Já a importância da responsabilidade, a interdependência e a preocupação com os outros podem se encaixar bem em argumentos do padrão moral racionalista consequencialista, no que se refere à análise de consequências. Na tabela 1 , observamos que os valores familiares relacionam-se exclusivamente com a ética do cuidado. 
O padrão moral intuitivo também foi bem representado nesse grupo de valores. Talvez as pessoas não se sintam tão inibidas em fornecer opiniões sem suportes racionais quando discutem sobre assuntos mais familiares e próximos. Afinal, os valores familiares desta discussão se referem a áreas da vida em que a maioria dos alunos tem alguma experiência pessoal, que possa basear posições intuitivas.

Outro grupo de valores em que a moral consequencialista surgiu com relativa importância foi o dos valores sociais. $\mathrm{Na}$ verdade, nenhum outro grupo de valores foi tão representado por esse padrão moral, em termos relativos. Novamente, a natureza dos valores pode explicar o resultado, já que boa parte das considerações sobre como as decisões podem afetar a coletividade se concentram em suposições de acontecimentos futuros e consequências. Para esse grupo de valores, o padrão moral emotivo não surgiu muitas vezes, talvez porque tais questões amplas não costumem gerar sentimentos de identificação tão fortes quanto as questões ligadas a decisões mais íntimas e familiares.

É interessante observar que quase todos os grupos de valores apareceram relacionados com todos os padrões morais, indicando que os mesmos valores podem surgir em abordagens completamente diferentes, como em uma análise de consequiências, na utilização de princípios, em posições guiadas pela emoção ou intuitivas. O único grupo de valores que não surgiu associado a todos os tipos de padrões morais foi o das regras de decisão.

As regras de decisão são quase totalmente representadas pelo raciocínio moral deontológico, já que representam princípios racionais de escolha por uma ou outra situação. Não houve nenhuma associação entre tais valores e o padrão moral racionalista consequencialista, apesar de tal relação não ser impossível, pelo menos no plano lógico.

Os dois outros grupos de valores, os valores relacionados a riscos, acidentes e responsabilidade e as considerações sobre respeito à vida e o valor da vida apresentaram-se bastante associados aos padrões morais deontológico e intuitivo. As posições intuitivas podem novamente ser reflexo da proximidade e familiaridade que os alunos teriam encontrado na utilização de tais valores, o que os deixaria, de certa forma, desinibidos para emitirem opiniões sem justificativas. Talvez seja mais provável que alguém tenha uma opinião intuitiva em alguma área da vida já conhecida ou envolvendo valores comumente utilizados. Já a ocorrência abundante do padrão moral deontológico pode ser explicada pela natureza desses dois grupos de valores, que, muitas vezes, evocariam princípios de deveres, responsabilidade ou ausência de responsabilidade no 
caso dos valores relacionados a riscos e responsabilidade, e princípios de respeito à vida ou de relativização do seu valor, no caso do outro grupo de valores.

Os valores do grupo riscos, acidentes e responsabilidade também são o segundo grupo de valores mais importantes associados à moral emotiva. Talvez isso se deva ao fato de que muitos argumentos que envolviam tais valores discutiam sobre o direito da mulher de abortar nos casos de estupro, já que ela não tinha controle sobre a concepção e sobre a responsabilidade dos jovens pais que têm de lidar com uma gravidez nãoplanejada, assuntos que costumam despertar posições carregadas de fortes reações emocionais.

Para todos os resultados, devemos considerar que tais dados foram coletados em um contexto escolar, através de uma atividade planejada e executada pelo professor da classe. Há, assim, grandes chances de que esse fator tenha deslocado os enunciados surgidos na discussão em prol do raciocínio moral (deontológico - de princípios - ou consequencialista) e em detrimento da moral emotiva, em virtude do que os alunos possivelmente esperavam que fossem as expectativas do professor.

As conclusões aqui apresentadas sobre as razões para a preponderância de um ou outro tipo de valor e suas relações com os padrões morais devem ser vistas com as devidas ressalvas, já que não é objetivo deste trabalho fazer uma análise psicológica profunda dos valores e dos padrões de pensamento dos adolescentes, mas sim descrever o processo argumentativo em uma discussão sociocientífica específica, que necessariamente envolve valores e padrões morais.

\section{Considerações Finais e Implicações para o Ensino}

A discussão sociocientífica sobre o aborto entre alunos de ensino fundamental se mostrou rica em valores e posições morais, às vezes com conceitos científicos integrados. A análise foi favorecida pela adequação mostrada pelo padrão de argumento de Toulmin (2003) como ferramenta de acesso a categorias de valores, mesmo que tal padrão não fosse comumente utilizado na literatura com essa finalidade.

Como podemos observar nas tabelas de argumentos deste trabalho, a utilização dos temas científicos controversos em discussões em grupo cria ambientes extremamente propícios ao exercício da argumentação, processo através do qual a Ciência é construída e, segundo Kuhn (1993), através do qual ela deveria ser ensinada. 
A argumentação que, por si só, já é um dos objetivos do ensino de ciências, também pode evidenciar conhecimento de conteúdo por parte dos estudantes, além de valores e abordagens morais.

Os padrões morais que os alunos utilizavam para resolver as questões propostas sobre o aborto variaram em diversidade de forma idêntica aos resultados de Sadler \& Zeidler (2005), inclusive com utilizações combinadas de padrões morais, como os autores já haviam notado. Assim, os alunos utilizaram posições intuitivas, emotivas, baseadas em princípios e consequencialistas, com prevalência da moral intuitiva, seguida pela utilização de princípios (raciocínio moral deontológico), pelo raciocínio consequencialista e, finalmente, pela moral emotiva.

O estudo dos padrões morais é extremamente relevante na área das questões sociocientíficas, já que permite o acesso aos tipos de raciocínio informal que os sujeitos utilizam ao abordar as questões morais. Tendo em vista que os processos do raciocínio informal geralmente são bem menos estudados do que o funcionamento do raciocínio formal, e que tais processos são os que surgem de fato na sala de aula e na vida em sociedade, quando surgem as questões polêmicas, fica clara a importância da identificação e descrição de tais categorias.

O conhecimento dos padrões morais fornece ao educador maior consciência do processo de debate, o que pode facilitar intervenções e a função de mediador, tarefa geralmente espinhosa que o professor deve cumprir quando propõe a discussão de assuntos polêmicos. Tais categorias também poderiam ser discutidas com os estudantes, com o intuito de favorecer a visão em perspectiva do mesmo tema, já que os alunos então poderiam perceber que realmente existem várias abordagens morais diferentes para uma mesma questão, e não necessariamente uma resposta certa.

O maior surgimento dos padrões morais intuitivo e deontológico (utilização de princípios) nos resultados pode ser efeito das características dos sujeitos analisados, do contexto de coleta de dados (caracterizado pela discussão em grupos no espaço escolar), da natureza do assunto discutido ou ainda de peculiaridades da forma pela qual as pessoas tomam decisões. Nesse último caso, cabe traçar um paralelo com o trabalho de Haidt (2001), no qual o autor propõe um modelo "social-intuicionista" de formação de julgamentos morais.

Segundo o modelo, já explicado anteriormente, os julgamentos morais geralmente surgiriam na mente das pessoas de forma rápida e sem esforço, como resultado de intuições morais (moral intuitiva). O raciocínio moral, como um processo 
que demanda esforço, surgiria depois, como numa tentativa de justificar o julgamento moral intuitivo. Os julgamentos morais racionalizados, uma vez verbalizados, podem influenciar, por vias afetivas, os julgamentos morais intuitivos de outras pessoas, que são diretamente afetadas por julgamentos morais alheios, mesmo sem quaisquer mecanismos explícitos de persuasão.

O modelo proposto por Haidt parece bastante plausível, mas seus processos não são passíveis de verificação neste trabalho, cuja metodologia não foi desenhada com esses propósitos. De uma certa forma, dentro dos devidos limites, podemos dizer que os resultados aqui apresentados são compatíveis com o modelo de Haidt, na medida em que os estudantes manifestaram principalmente os tipos de raciocínio intuitivo e racionalista deontológico. A prevalência da moral intuitiva no presente trabalho pode estar relacionada à tese de Haidt, ou seja, de que as pessoas tomam decisões principalmente de forma intuitiva, ou a algum tipo de economia de energia cognitiva utilizada pelos estudantes, já que produzir julgamentos utilizando o raciocínio seria mais custoso que por vias intuitivas, ainda mais quando os colegas já fornecem explicações racionais para determinada posição moral - ideia sugerida pelo próprio Haidt (2001).

Aqui, não foi observada a sequência proposta pelo autor, até porque não seria possível, pela natureza dos dados, acompanhar todos os julgamentos morais intuitivos, em função de não termos acesso ao pensamento dos sujeitos senão através da fala, que, por sua vez, representa os conteúdos mentais de forma dependente de circunstâncias externas, como dinâmica e relações de dominância no grupo, e internas, como a personalidade e estados afetivos momentâneos. Novamente, o dado ao qual temos acesso é o argumento que, enquanto tipo de comportamento, não deve ser confundido com a dinâmica de relações internas na mente dos indivíduos, ou seja, o raciocínio informal em si (MATURANA \& VARELA, 2007).

Tal limitação faz com que muitas vezes o único resultado acessível seja o raciocínio moral expresso através do argumento, que o sujeito elaborou após a intuição moral, mas que não explicitou antes. $\mathrm{O}$ que observamos aqui foram muitas proposições dos dois tipos, mas não necessariamente na ordem proposta por Haidt, ou seja, moral intuitiva, seguida pelo raciocínio moral, que então teria efeito sobre os julgamentos morais dos colegas. O efeito das opiniões emitidas sobre os outros integrantes dos grupos seria um dado muito interessante também, mas para acessá-lo, provavelmente teríamos que introduzir ferramentas ligadas à interação e ao funcionamento dos grupos. 
Mesmo assim, o acesso continuaria limitado ao conteúdo explicitado pelos sujeitos, e não à totalidade dos julgamentos morais, cuja análise se faria necessária para comprovar a tese de Haidt (2001).

A pesquisa de Haidt ainda se faz importante para comprovar a importância das discussões envolvendo temas sociocientíficos entre alunos. De acordo com o autor, as pessoas só utilizam o raciocínio moral objetivamente em condições muito limitadas, dado que a razão quase nunca é usada para questionar as próprias crenças ou atitudes e as decisões geralmente são tomadas intuitivamente. Associando tal ideia com os resultados do presente trabalho, concluímos que as discussões de temas controversos são ótimas oportunidades de utilização de raciocínio moral, já que vimos que esse foi um dos padrões morais dominantes na discussão. Os dados aqui apresentados também permitem concluir que a discussão sociocientífica é uma ótima oportunidade de utilização de conceitos científicos, já que estes estiveram principalmente relacionados ao abundante padrão moral racionalista deontológico.

Outros trabalhos que pretendam investigar profundamente tais questões, que envolvem interação e julgamento moral em questões sociocientíficas na sala de aula, deverão mostrar resultados interessantes e importantes para guiar pesquisas na área de psicologia moral e ensino, além da prática de profissionais de educação.

Outra contribuição deste trabalho se refere à verificação dos papéis que valores e conceitos científicos desempenham na discussão sociocientífica, mais especificamente nos argumentos produzidos. Os valores corroboraram sua função de garantia prevista na literatura (KOLSTO, 2006), como sentenças hipotéticas, genéricas ou de ligação entre dados e conclusões, além de surgirem em outras posições nos argumentos, o que nos mostra que os valores, em uma discussão sociocientífica, podem ser usados até para suportar afirmações, quando exercem função de dados. Já os conceitos científicos, exercendo principalmente a função de dados dos argumentos, representam, de certa forma, o discurso de autoridade da Ciência, conferindo legitimidade aos argumentos e às demais proposições onde apareciam. Outras funções para os conceitos científicos nos argumentos também se mostraram possíveis, como conclusão, qualificador, refutador e apoio.

Ainda com relação aos conceitos, uma discussão importante na literatura que surge neste trabalho se refere ao papel do conhecimento do conteúdo científico na discussão sociocientífica. Para muitos autores, fatores morais e emotivos parecem ter bastante influência em relação ao domínio de conceitos científicos associados para a 
resolução das questões sociocientíficas (SADLER \& ZEIDLER, 2004; BELL \& LEDERMAN, 2003; HOGAN, 2002; KORTLAND, 1996; PATRONIS et al., 1999; SADLER, CHAMBERS \& ZEIDLER, 2004; SADLER \& ZEIDLER, 2004; YANG \& ANDERSON, 2003; ZEIDLER \& SCHAFER, 1984; ZEIDLER et al., 2002).

Os dados aqui apresentados não nos permitem fazer afirmações sobre a extensão da importância do conhecimento científico para a tomada de decisões em questões sociocientíficas, já que não temos informações precisas sobre o nível de conhecimento específico dos sujeitos analisados, mas é evidente que a discussão sociocientífica se mostrou uma ótima oportunidade de utilização de raciocínio moral e de integração de conceitos científicos, que exerciam importantes funções nos argumentos.

Os conceitos, que eram utilizados geralmente como legitimadores dos argumentos, trazendo a autoridade científica à discussão, parecem ainda exercer, junto com os valores e considerações morais, funções complementares, já que geralmente ocupam posições distintas no Padrão de Argumento segundo Toulmin (2003). É possível que a utilização conjunta de tais categorias, ou seja, conceitos e valores, tenha efeitos diferenciados nas posições morais intuitivas dos colegas, e trabalhos voltados a tais objetivos devem revelar resultados interessantes, ao permitir mensurar a importância dos conceitos científicos na discussão sociocientífica.

Tendo em vista a espontaneidade com a qual os conceitos científicos surgiram na discussão de tais alunos - que são relativamente novos - e a ampla utilização de padrões racionalistas, com possibilidade de reflexão sobre crenças e valores comumente não questionados individualmente, podemos considerar as discussões sociocientíficas como eficientes ferramentas promotoras de alfabetização científica, já que familiarizam os estudantes com temas relevantes à Ciência e à Sociedade, além de permitirem trocas de conhecimentos e valores úteis na abordagem de problemas reais.

Os valores utilizados na discussão sobre o aborto entre estudantes de ensino fundamental, representantes da classe média alta brasileira, mostraram grande variação e puderam ser classificados conforme as linguagens éticas propostas por Carol Gilligan: a ética do cuidado e a ética da justiça. Da mesma forma que no trabalho da autora, que analisou mulheres argumentando sobre o aborto, aqui também prevaleceram valores ligados à ética do cuidado, já que estavam ligados aos ideais de responsabilidade, cuidado parental, manutenção de relações, segurança financeira relacionada ao cuidado familiar, compaixão e conexão. 
É interessante observar que, apesar de a maioria dos padrões morais utilizados terem sido racionalistas, os valores que prevaleceram foram os valores de cuidado, geralmente associados à ideia de emoção. Isso pode ser explicado pelo fato de que tais valores não precisam ser necessariamente associados ao padrão moral emotivo, já que a ética do cuidado também pode ser expressa através de princípios de cuidado e responsividade, ou de análises de conseqüências referentes a responsabilidades e manutenção de relações, associando tais valores com padrões morais racionalistas deontológicos (de princípios) e consequencialistas, que surgiram mais vezes que o padrão emotivo.

A ampla utilização da ética do cuidado por parte dos alunos nos mostra que tal linguagem moral é presente na sala de aula e, já que surge no processo de resolução de questões que se relacionam ao conteúdo, merece maior atenção por parte de professores de Ciências e de outras disciplinas. A exploração, explicitação e tomada de consciência de tais valores poderiam ser utilizados pela escola como caminho para o fortalecimento dos ideais de coletividade, senso de responsabilidade, respeito mútuo, compaixão e preservação (do ambiente e dos bens coletivos), valores extremamente desejáveis que os professores, graduados e treinados em áreas de conhecimento pretensamente objetivas e neutras, nem sempre sabem como trabalhar.

A linguagem ética da justiça, identificada por Gilligan como correspondente aos ideais dos níveis de desenvolvimento moral de Kohlberg, apareceu neste trabalho muitas vezes associada a valores que eram predominantemente deontológicos, o que faz sentido, considerando-se que estão relacionados a princípios de justiça, equidade e regras absolutas de certo e errado. Tais valores também podem e devem ser trabalhados em escolas preocupadas com o caráter e a formação moral de seus estudantes. Cabe lembrar que, para Kohlberg, a discussão de temas polêmicos entre indivíduos de diferentes níveis de moralidade serviria como estímulo para o desenvolvimento moral das pessoas.

A importância dos valores nos processos de discussão sociocientífica é notável, já que foram muito abundantes e muitas vezes eles eram detectáveis até em asserções sem justificativas. Os valores fazem parte dos argumentos e permitem decidir entre opções complexas e problemáticas, que o raciocínio formal dificilmente resolveria. Além de serem essenciais nas discussões de temas polêmicos, os valores também regulam e permeiam a vida em sociedade, cabendo aos professores e à escola a função de não se esquivar de trabalhá-los em seus currículos. 
Essa ideia caminha no sentido de uma visão de Ciência menos positivista, já que, ao assumirmos que a Ciência não é neutra, mas movida por interesses, paixões e valores, devemos também nos comprometer a transmitir tal noção, tarefa que pode se beneficiar muito de um ensino que integre valores. A Ciência também gera continuamente demandas éticas, já que muitas questões polêmicas têm sua gênese no próprio desenvolvimento tecnológico, como é o caso dos transgênicos ou das possibilidades de manutenção estendida da vida. Podemos ainda pensar que o ensino de ciências possui uma responsabilidade especial sobre a educação moral das pessoas, em virtude do poder que a Ciência tem de produzir destruição, desigualdade, sofrimento, ou então progresso, harmonia e bem-estar, tudo em função dos valores e interesses daqueles que a comandam e/ou fazem.

É preciso que as questões sociocientíficas tenham uma posição de destaque no ensino de ciências, em contextos escolares nos quais os valores e o caráter sejam o assunto, não apenas em salas de coordenação, reuniões de pais ou ocasiões especiais, mas dentro da sala de aula, como um dos itens primordiais do currículo. Talvez esse seja um dos caminhos necessários para que o nosso mundo civilizado possa promover uma transição efetiva para uma cultura de paz e igualdade, problema que ainda não obteve solução por meio da alta tecnologia ou da liberdade conferida aos sistemas econômicos. 


\section{Referências}

ADAM, J. M. (1992). Les textes: types et prototypes. París: Nathan.

AIKENHEAD, G. S. (1987). High-school graduates' beliefs about Science-TechnologySociety. III. Characteristics and limitations of scientific knowledge. Science Education, 71(4), 459-487.

ANDREW, J. \& ROBOTTOM, I. (2001). Science and Ethics: Some Issues for Education. Science Education, 85, 769-780.

BECKWITH, F. J. (2005) Of souls, selves, and cerebrums: a reply to Himma. J. Med. Ethics. 31: 56-60.

BELL, R. L., \& LEDERMAN, N. G. (2003). Understandings of the nature of science and decision making on science and technology based issues. Science Education, 87(3), 352-377.

BENNETT, J., HOGARTH, S., LUBBEN, F. (2005). A systematic review of the effects of context-based and Science-Technology-Society (STS) approaches in the teaching of secondary science: Review summary. University of York, UK.

BLAIR, R. J. R. (1997). Affect and the moral-conventional distinction. Journal of Moral Education, 26, 187-196.

BORTOLOTTI, L. (2007) Disputes Over Moral Status: Philosophy and Science in the Future of Bioethics. Health Care Anal. 15:153-158.

BROWN, T. C. (1984). The Concept of Value in Resource Allocation. Land Economics, Vol. 60, No. 3, pp. 231-246.

CAJAS, F. (1999). Public understanding of science: Using technology to enhance school science in everyday life. International Journal of Science Education, 21, 765773.

CLARKE, L. (1999) The Person in Abortion. Nursing Ethics. 6 (1).

COLL, C. \& ONRUBIA, J. (1998). “A construção de significados compartilhados em sala de aula: atividade conjunta e dispositivos semióticos no controle e no acompanhamento mútuo entre professor e alunos. In COLL, C.; EDWARDS, D. (orgs.). Ensino, aprendizagem e discurso em sala de aula. Porto Alegre: Artmed, 1998.

CONTIER, D. (2009) Relações entre ciência, tecnologia e sociedade em museus de ciências. Tese de Mestrado - Faculdade de Educação da Universidade de São Paulo, São Paulo.

CORRALIZA, J. A. \& BERENGUER, J. (2000). Environmental Values, Beliefs, and Actions: A Situational Approach. Environment and Behavior, 32; 832. 
DIJK, T.A. Van (1978). La ciencia del texto. Barcelona: Paidós.

DONLEAVY, G. D. (2008). No Man's Land: Exploring the Space between Gilligan and Kohlberg. Journal of Business Ethics, 80:807 - 822.

DRIVER, R., NEWTON, P., \& OSBORNE, J. (2000). Establishing the Norms of Scientific Argumentation in Classrooms. Science Education, 84, 287-312.

ERDURAN, S., SIMON, S. \& OSBORNE, J. (2004). TAPping into Argumentation: Developments in the Application of Toulmin's Argument Pattern for Studying Science Discourse. Science Education, 88, 915-933.

FLEMING, R. (1986). Adolescent reasoning in socio-scientific issues. Part II: Nonsocial cognition. Journal of Research in Science Teaching, 23, 689-698.

FLEMING, R. (1987). High-school graduate's beliefs about Science-TechnologySociety. II. The interaction among Science, Technology and Society. Science Education, v. 71 n. 2 p. 163-86.

FORD, M., \& LOWERY, C. (1986). Gender differences in moral reasoning: A comparison of the use of justice and care orientations. Journal of Personality and Social Psychology, 50, 777-783.

FOUREZ, G. (2003). 'Crise no Ensino de Ciências?'. Investigações em Ensino de Ciências, 8(2). Disponível em: http://www.if.ufrgs.br/public/ensino/vol8/n2/v8_n2_a1.html

GEDDIS, A. N. (1991). Improving the Quality of Science Classroom Discourse on Controversial Issues. Science Education, 75(2), 169-183.

GILLIGAN, C. (1998). Remembering Larry. Journal of Moral Education, 27:2,125 140.

GILLON, R. (2001) Is there a 'new ethics of abortion'? J. Med. Ethics. 27: 5-9.

GRACE, M. M. \& RATCLIFFE, M. (2002). The Science and Values that Young People Draw Upon to Make Decisions about Biological Conservation Issues. International Journal of Science Education, 24(11), 1157-1169.

GUMP, L. S.; BAKER, R. C. \& ROLL, S. (2000) Cultural and Gender Differences in Moral Judgment: A Study of Mexican Americans and Anglo-Americans. Hispanic Journal of Behavioral Sciences, 22; 78.

HAIDT, J. (2001). The Emotional Dog and Its Rational Tail: A Social Intuitionist Approach to Moral Judgment. Psychological Review, 108(4), 814-834.

HASTE, H. \& ABRAHAMS, S. (2008) Morality, culture and the dialogic self: taking cultural pluralism seriously. Journal of Moral Education, 37:3, 377 - 394. 
HIMMA, K. E. (2005) A dualist analysis of abortion: personhood and the concept of self qua experiential subject J. Med. Ethics. 31: 48-55.

HOGAN, K. (2002). Small groups' ecological reasoning while making na environmental management decision. Journal of Research in Science Teaching, 39, 341368.

HURST, J. (2006) Uma história não contada - a historia das ideias sobre o aborto na Igreja Católica. São Paulo: Católicas pelo direito de decidir (Coleção Cadernos; 1).

IBGE. Instituto Brasileiro de Geografia e Estatística. Tabelas de resultados - Parte A Indicadores de 2006 e 2007. Disponível em:

http://www.ibge.gov.br/home/estatistica/populacao/trabalhoerendimento/pnad2007/sinte se/tab3_2.pdf. Acesso em: 9 de novembro de 2008.

JIMÉNEZ-ALEIXANDRE, M. P., RODRÍGUEZ, A. B., \& DUSCHL, R. A. (2000). "Doing the lesson" or "Doing Science": Argument in High School Genetics. Science Education, 84, 757-792.

JIMÉNEZ-ALEIXANDRE, M. P. \& DÍAZ de BUSTAMANTE, J. (2003). Discurso de Aula Y Argumentación em la Clase de Ciencias: Cuestiones Teóricas y Metodológicas. Enseñanza de las Ciencias, 21(3), 359-370.

JORGENSEN, G. (2006) Kohlberg and Gilligan: duet or duel?. Journal of Moral Education, 35:2, 179 - 196.

KARPIAK, C. P. \& BARIL, G. L. (2008). Moral reasoning and concern for the environment. Journal of Environmental Psychology, 28, 203 - 208.

KEEFER, M. W. (1996). The inseparability of morality and personal well being: The duty/virtue debate in moral education — revisited. Journal of Moral Education, 25, 277290.

KOLSTO, S. D. (2001). 'To trust or not to trust, .. . '-pupils' ways of judging information encountered in a socio-scientific issue. International Journal of Science Education, 23, 877-901.

KOLSTO, S. D. (2006). Patterns in Students' Argumentation Confronted with a Riskfocused Socio-scientific Issue. International Journal of Science Education, 28(14), 1689-1716.

KORPAN, C. A., BISANZ, G. L., BISANZ, J., \& HENDERSON, J. M. (1997). Assessing literacy in science: Evaluation of scientific news briefs. Science Education, 81, 515-532.

KORTLAND, K. (1996). Decision-making on science-related social issues: The case of garbage in physical science - a problem-posing approach. In G. Welford, J. Osborne, \& P. Scott (Eds.), Research in science education in Europe. Current issues and themes (pp. 115-124). London: Falmer Press. 
KUHN, D. (1991). The skills of argument. Cambridge: Cambridge University Press.

KUHN, D. (1993). Science as argument: Implications for teaching and learning scientific thinking. Science Education, 77, 319-337.

KURJAK, A., CARRERA, J. M., McCULlOUGH, L. B., CHERVENAK, F. A. (2007) Scientific and religious controversies about the beginning of human life: the relevance of the ethical concept of the fetus as a patient J. Perinat. Med. 35: 376-383.

LAURENTI, R. (1995) “Perfil da Mortalidade Materna”. In MINAYO (org.). Muitos Brasis: Saúde e População na Década de 80. São Paulo: Abrasco/Hucitec.

LEAL, O. F. (1998) “Corpo, Sexualidade e Aborto”. In DEBERT \& GOLDSTEIN (orgs.). Políticas do Corpo e o Curso da Vida. São Paulo: Editora Sumaré.

LISKER, R. (2003) Ethical and Legal Issues in Therapeutic Cloning and the Study of Stem Cells. Archives of Medical Research. 34: 607-611.

LOREA, R. A. (2006) “Aborto e Direito no Brasil”. In CAVALCANTE \& XAVIER (orgs.). Em Defesa da Vida: Aborto e Direitos Humanos. São Paulo: Católicas pelo Direito de Decidir.

MATURANA, H. R. \& VARELA, F. J. (2007). A Árvore do Conhecimento - as bases biológicas da compreensão humana. São Paulo: Editora Palas Athena.

MILLAR, R. (1996) Towards a science curriculum for public understanding. School Science Review, 77 (280), 7-18.

MILLS, C. (2005) Technology, embodiment and abortion. Internal Medicine Journal. 35: 427-428.

MORAES, R. (2005) "Mergulhos Discursivos” In GALIAZZI, M. C. (Org.), FREITAS, J. V. (Org.). Metodologias Emergentes de Pesquisa em Educação Ambiental. Eds. Ijuí: Unijuí.

MORTON, K. R.; WORTHLEY, J. S.; TESTERMAN, J. K. \& MAHONEY, M. L. (2006) Defining features of moral sensitivity and moral motivation: pathways to moral reasoning in medical students. Journal of Moral Education, 35:3, 387 - 406.

NARVAEZ, D. (2008) Triune ethics: The neurobiological roots of our multiple moralities. New Ideas in Psychology, 26, 95 - 119.

OREG, S. \& KATZ-GERRO, T. (2006). Predicting Proenvironmental Behavior CrossNationally: Values, the Theory of Planned Behavior, and Value-Belief-Norm Theory. Environment and Behavior, 38; 462.

OSBORNE, J., ERDURAN, S. \& SIMON, S. (2004). Enhancing the Quality of Argumentation in School Science. Journal of Research in Science Teaching, 41(10), 994-1020. 
OULTON, C., DILLON, J. \& GRACE, M. M. (2004). Reconceptualizing the teaching of controversial issues. International Journal of Science Education, 26(4), 411 - 423.

PATRONIS, T., POTARI, D., \& SPILIOTOPOULOU, V. (1999). Students' argumentation in decision-making on a socio-scientific issue: Implications for teaching. International Journal of Science Education, 21, 745-754.

PEDRETTI, E. (1999). Decision making and STS education: Exploring scientific knowledge and social responsibility in schools and science centers through an issuesbased approach. School Science and Mathematics, 99, 174-181.

PEDRETTI, E., \& HODSON, D. (1995). From rhetoric to action: Implementing STS education through action research. Journal of Research in Science Teaching, 32(5), 463-485.

POULIOT, C. (2008). Students' Inventory of Social Actors Concerned by the Controversy Surrounding Cellular Telephones: A Case Study. Science Education, 92, 543-559.

RATCLIFFE, M. (1996). Adolescent decision-making, by individuals and groups, about science-related social issues. In G. Welford, J. Osborne, \& P. Scott (Eds.), Research in science education in Europe. Current issues and themes (pp. 126-140). London: Falmer Press.

RATCLIFFE, M. (1997). Pupil decision-making about socio-scientific issues within the science curriculum. International Journal of Science Education, 19(2), 167-182.

RESNICK, D. (2008) Life in an unjust community: a Hollywood view of high school moral life. Journal of Moral Education, 37:1, 99 - 113.

ROCHA, M. I. B. \& NETO, J. A. (2003) “A questão do aborto - Aspectos clínicos, legislativos e políticos”. In BERQUÓ (org.). Sexo \& Vida - Panorama da Saúde Reprodutiva no Brasil. Campinas, SP: Editora da Unicamp.

ROSADO-NUNES, M. J. (2006) “Aborto, maternidade e a dignidade da vida das mulheres". In CAVALCANTE \& XAVIER (orgs.). Em Defesa da Vida: Aborto e Direitos Humanos. São Paulo: Católicas pelo Direito de Decidir.

RUBBA, P. A.; HARKNESS, W. L.. Examination of preservice and in-service secondary science teachers' beliefs about Science-Technology-Society interactions. Science Education, v. 77 n. 4 p. 407-31, Jul 1993.

SADLER, T. D., BARAB, S. A. \& SCOTT, B. (2007). What Do Students Gain by Engaging in Socioscientific Inquiry? Research in Science Education, 37, 371-391.

SADLER, T. D. (2004). Informal Reasoning Regarding Socioscientific Issues: A

Critical Review of Research. Journal of Research in Science Teaching, 41(5), 513-536. 
SADLER, T. D., CHAMBERS, W. F. \& ZEIDLER, D. L. (2004). Student Conceptualizations of the Nature of Science in Response to a Socioscientific Issue. International Journal of Science Education, 26(4), 387 - 409.

SADLER, T. D. \& DONNELLY, L. A. (2006). Socioscientific Argumentation: The Effects of Content Knowledge and Morality. International Journal of Science Education, 28(12), 1463-1488.

SADLER, T. D. \& FOWLER, S. R. (2006). A Threshold Model of Content Knowledge Transfer for Socioscientific Argumentation. Science Education, 90, 986-1004.

SADLER, T. D. \& ZEIDLER, D. L. (2004). The Morality of Socioscientific Issues: Construal and Resolution of Genetic Engineering Dilemmas. Science Education, 88, 427.

SADLER, T. D. \& ZEIDLER, D. L. (2005a). Patterns of Informal Reasoning in the Context of Socioscientific Decision Making. Journal of Research in Science Teaching, $42(1), 112-138$.

SADLER, T. D. \& ZEIDLER, D. L. (2005b). The Significance of Content Knowledge for Informal Reasoning Regarding Socioscientific Issues: Applying Genetics Knowledge to Genetic Engineering Issues. Science Education, 89, 71-93.

SANTOS, M.E.V.M.- A cidadania na "voz" dos manuais escolares. Livros Horizonte, Lisboa, p. 170-209, 2001.

SARDÀ JORGE, A. \& SANMARTÍ PUIG, N. (2000). Enseñar a argumentar científicamente: um reto de las clases de ciências. Enseñanza de las Ciencias, 18(3), 405-422.

\section{SECRETARIA DE ECONOMIA E PLANEJAMENTO DO ESTADO DE SÃO}

PAULO. Tabelas - Renda Familiar, Distribuição dos Domicílios, por Faixas de Renda Familiar, segundo Distritos, Município de São Paulo, 2000. Disponível em : http://www.seade.gov.br/produtos/msp/index.php?tip=met4\&opt=s\&tema=REN\&subte $\underline{m a}=1$. Acesso: em 20 de outubro de 2009.

SHERBLOM, S. (2008) The legacy of the 'care challenge': re-envisioning the outcome of the justice-care debate. Journal of Moral Education, 37:1, 81 - 98.

SIMONNEAUX, L. (2001). Role-play or Debate to Promote Students' Argumentation and Justification on an Issue in Animal Transgenesis. International Journal of Science Education, 23(9), 903-927.

SINGER P. (1993) Practical ethics second edition. Cambridge: Cambridge University Press.

SOBER, E. (1996) Filosofía de la biología. Alianza Editorial. Madrid. 
SOLOMON, J. (1992) The classroom discussion of science-based social issues presented on television: knowledge, attitudes and values. International Journal of Science Education, 14(4), 431-444.

TAPPAN, M. B. (2006) Moral functioning as mediated action. Journal of Moral Education, 35:1, $1-18$.

TISAK, M., \& TURIEL, E. (1988). Variations in seriousness of transgressions and children's moral and conventional concepts. Developmental Psychology, 24, 352-357.

TOOLEY M. (1983). Abortion and infanticide. Oxford: Clarendon.

TOULMIN, S. E. (2003). The Uses of Argument. Cambridge, UK: University Press.

TYTLER, R., DUGGAN, S., \& GOTT, R. (2001). Dimensions of Evidence, the Public Understanding of Science and Science Education. International Journal of Science Education, 23, 815-832.

von AUFSCHNAITER, C., ERDURAN, S., OSBORNE, J. \& SIMON, S. (2008). Arguing to Learn and Learning to Argue: Case Studies of How Students' Argumentation Relates to Their Scientific Knowledge. Journal of Research in Science Teaching, 45(1), 101-131.

WALKER, K. A. \& ZEIDLER, D. L. (2007). Promoting Discourse about Socioscientific Issues through Scaffolded Inquiry. International Journal of Science Education, 29(11), 1387-1410.

WALKER, L. J. \& FRIMER, J. A. (2009) 'The song remains the same': rebuttal to Sherblom's reenvisioning of the legacy of the care challenge. Journal of Moral Education, 38:1, $53-68$.

WATSON, J. R., SWAIN, J. R. L. \& McROBBIE, C. (2004). Students' discussions in practical scientific inquiries. International Journal of Science Education, 26(1), 25-45.

WERTSCH, J. (1998) Mind as action. New York, Oxford University Press.

WILAND, E. (2000) Unconscious violinists and the use of analogies in moral argument. J. Med. Ethics. 26: 466-468.

WU, Y. T. \& TSAI, C. C. (2007). High School Students' Informal Reasoning on a Socio scientific Issue: Qualitative and Quantitative Analyses. International Journal of Science Education, 29(9), 1163-1187.

YANG, F. Y. \& ANDERSON, O. R. (2003). Senior high school students' preference and reasoning modes about nuclear energy use. International Journal of Science Education, 25(2), 221-244.

ZEIDLER, D. L. \& KEEFER, M. (2003). The Role of Moral Reasoning and the Status of Socioscientific Issues in Science Education: Philosophical, Psychological and Pedagogical Considerations. In D. L. ZEIDLER (Ed.), The Role of Moral Reasoning 
and Discourse on Socioscientific Issues in Science Education (pp. 7-38). Dordrecht: Klwer.

ZEIDLER, D. L. (1984). Moral issues and social policy in science education: Closing the literacy gap. Science Education, 68(4), 411-419.

ZEIDLER, D. L., SADLER, T. D., SIMMONS, M. L. \& HOWES, E. V. (2005). Beyond STS: A Research-Based Framework for Socioscientific Issues Education. Science Education, 89, 357-377.

ZEIDLER, D. L. \& SCHAFER, L. E. (1984). Identifying mediating factors of moral reasoning in science education. Journal of Research in Science Teaching, 21, 1-15.

ZEIDLER, D. L., WALKER, K. A., ACKETT, W. A. \& SIMMONS, M. L. (2002). Tangled Up in Views: Beliefs in the Nature of Science and Responses to Socioscientific Dilemmas. Science Education, 86, 343-367.

ZOHAR, A., \& NEMET, F. (2002). Fostering students' knowledge and argumentation skills through dilemmas in human genetics. Journal of Research in Science Teaching, 39, 35-62.

ZOLLER, U.; SCHOLZ, R. W.. The HOCS paradigm shift from disciplinary knowledge (LOCS) - to interdisciplinary evaluative, system thinking (HOCS): what should it take in science-technology-environment-society oriented courses, curricula and assessment? Water Science and Technology, v. 49 n. 8 p. 27-36, 2004.

ZUCKER, G.S. (1999) Attributional and Symbolic Predictors of Abortion Attitudes. Journal of Applied Social Psychology, 29, 6, pp. 1218 - 1245. 


\begin{abstract}
Anexo I
Respondam às perguntas sem pressa, discutindo bastante entre o grupo. Lembrem-se das regras: 1 - Não falar "atropelando" o colega; 2 - Sempre dar e pedir opiniões; 3 Sempre dar e pedir justificativas para as afirmações; 4 - Levar a discussão a sério; 5 - Tomar as decisões em grupo, não individualmente.

Escrevam (nos espaços e no verso) a conclusão do grupo para cada questão, lembrando que, se o consenso não for atingido, as diferentes opiniões devem ser escritas. Boa discussão!!!

1 - Com relação à legislação sobre o aborto, há países do mundo que permitem o aborto em qualquer circunstância, outros que permitem com restrições e outros que pró́bem totalmente. As leis relativas ao aborto também variaram bastante ao longo da história, com povos que consideravam a prática de aborto permitida e povos que a consideravam proibida. Imaginem agora que vocês são os governantes de um novo país (imaginário) e devem criar uma legislação (um conjunto de leis) sobre o aborto. Escrevam, em algumas linhas, essas leis, lembrando que nelas deve ficar claro se o país permitirá ou não a realização do aborto e, se permitir, em quais casos o aborto será permitido.
\end{abstract}

2 - Ainda pensando que vocês são os governantes desse país imaginário, suponham que vocês convocarão vários profissionais de diferentes áreas para ajudá-los a definir se o aborto deve ser permitido ou não no país imaginário. Quais são os tipos de profissionais que vocês chamarão para ajudá-los a tomar essa decisão?

3 - Jane é uma menina de 16 anos muito inteligente que quer se tornar médica. Ela namora Ricky há um ano e eles decidiram juntos ter a primeira relação sexual. Como ela e o namorado são prevenidos e informados, eles não se esqueceram de usar uma camisinha. No entanto, durante o ato sexual a camisinha (que não é 100\% segura) se rompeu e eles acabaram não percebendo. Pouco mais de um mês depois, como a menstruação de Jane não "vinha", ela descobriu, indo ao médico, que havia engravidado. Jane se vê então com problemas, pois, para criar um filho, ela deverá parar de estudar e começar a trabalhar. O que Jane deve fazer agora? Que planos ela deve fazer?

4 - Ainda pensando no mesmo caso, Ricky, que tem 18 anos, acabou de entrar para o curso de engenharia em uma conceituada Universidade. Para criar um filho, ele terá de abandonar os estudos e começar a trabalhar em alguma outra função. $\mathrm{O}$ que ele deve fazer ou propor para Jane? 
Respondam às perguntas sem pressa, discutindo bastante entre o grupo. Lembrem-se das regras: 1 - Não falar "atropelando" o colega; 2 - Sempre dar e pedir opiniões; 3 Sempre dar e pedir justificativas para as afirmações; 4 - Levar a discussão a sério; 5 - Tomar as decisões em grupo, não individualmente.

Escrevam (nos espaços e no verso) a conclusão do grupo para cada questão, lembrando que, se o consenso não for atingido, as diferentes opiniões devem ser escritas. Boa discussão!!!

5 - Quando o grupo considera que ocorre o início da vida de uma pessoa humana: no momento em que o espermatozóide encontra o óvulo, no momento em que o zigoto se fixa no útero, quando o sistema nervoso começa a se desenvolver no embrião, quando a mãe começa a sentir o bebê na barriga, no momento do nascimento ou ainda em algum outro momento? Por quê?

6 - A "pílula do dia seguinte" age da seguinte forma: se a fecundação ainda não tiver ocorrido, ela dificulta o encontro do espermatozóide com o óvulo; se a fecundação já houver ocorrido, ela provocará uma descamação do útero, impedindo a implantação do zigoto. Vocês consideram a pílula do dia seguinte um método abortivo? No seu país imaginário ela seria liberada ou proibida?

7 - A Lei brasileira permite o aborto nos casos em que a gravidez ou o parto representam riscos de vida para a mãe e também quando a gravidez é fruto de um estupro. O grupo concorda com essa lei? Se concorda, ou concorda com apenas alguma parte, por quê? Se não concorda, por quê?

8 - Qual das vidas vocês consideram mais importante? A da mãe ou a do bebê (ou embrião, ou feto)? Por quê? 


\begin{abstract}
Anexo II
Com relação à legislação sobre o aborto, há países do mundo que permitem o aborto em qualquer circunstância, outros que permitem com restrições e outros que proíbem totalmente. As leis relativas ao aborto também variaram bastante ao longo da história, com povos que consideravam a prática de aborto permitida e povos que a consideravam proibida. imaginem agora que vocês são os governantes de um novo país (imaginário) e devem criar uma legislação (um conjunto de leis) sobre o aborto. Escrevam, em algumas linhas, essas leis, lembrando que nelas deve ficar claro se o país permitirá ou não a realização do aborto e, se permitir, em quais casos o aborto será permitido.
\end{abstract}

Nós discutimos e chegamos à conclusão de que dependendo do caso ser estuprada ou não Grupo E tiver condições para criar o filho poderiam pensar no caso de fazer ou não o aborto, pois não M adiantaria nada ter o bebê e jogá-lo e deixar ele sozinho, logo após o nascimento, pois se ele fosse legalizado todos fariam sexo sem segurança e veriam o aborto como uma solução para seus problemas.

Nós discutimos e chegamos à conclusão que dependendo do caso, se for estuprada ou não tiver condições de criar, poderá levar em conta e pensar no aborto como uma possível "solução".

$\begin{array}{cl}\text { Grupo D } & \text { Se nosso país existisse o aborto seria proibido, porque é a mesma coisa que matar uma vida, } \\ \text { C } & \text { pois é a morte de um embrião. Somente em um caso seria permitido: risco de vida da mãe. } \\ \text { A } & \text { Não seria permitido o aborto tirando a quando a mãe tem risco de morrer. } \\ \text { B } & \text { Seria feito o aborto se: estupro, doença mental e risco de vida da criança ou da mulher. } \\ \text { K } & \text { O aborto não seria permitido, só em casos extremos: estupro, risco de morte. }\end{array}$

Grupo B O aborto seria legalizado, mas, as mulheres só poderiam abortar quando tiver risco à saúde G (uma gravidez de risco), colocar a saúde mental da mãe em risco e quando a mãe for estuprada.

O aborto será legalizado mas, as mulheres só poderiam abortar quando for uma gravidez de A alto risco, colocar a saúde mental da mãe em risco e quando houver caso de estupro.

$\mathrm{R} \quad \mathrm{O}$ aborto deverá ser legalizado nos casos de estupramento, quando a mãe estiver correndo risco, ou se a pessoa não tiver condições psicológicas de das a luz.

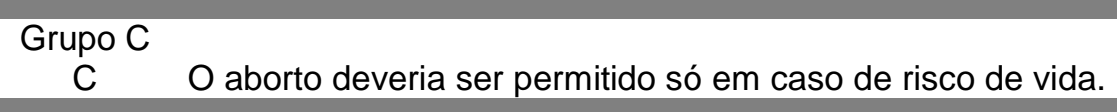

\title{
Grupo A
}

T Eu acho/nós achamos que o aborto deveria ser proibido porque é uma vida e poderia ser você.

Jane é uma menina de 16 anos muito inteligente que quer se tornar médica. Ela namora Ricky há um ano e eles decidiram juntos ter a primeira relação sexual. Como ela e o namorado são prevenidos e informados, eles não se esqueceram de usar uma camisinha. No entanto, durante o ato sexual a camisinha (que não é

$100 \%$ segura) se rompeu e eles acabaram não percebendo. Pouco mais de um mês depois, como a menstruação de Jane não "vinha", ela descobriu, indo ao médico, que havia engravidado. Jane se vê então com problemas, pois, para criar um filho, ela deverá parar de estudar e começar a trabalhar. O que Jane deve fazer agora? Que planos ela deve fazer?

Grupo E Eles deveriam conversar e os dois conciliarem tudo pois não seria justo apenas Jane largar

M tudo para ser mãe, deveriam dividir as funções para nenhuma das partes serem afetadas.

C Que o mais correto seria eles conciliarem a criança e o estudo, e se eles se gostam, não há motivo para abortar.

Grupo D Jane deveria assumir a criança, continuar estudando ficar com 7 de gravidez e trancar a

C faculdade neste período.

A Ela deveria assumir e tentar mais tarde fazer a faculdade e os pais devem ajudar.

B Se fosse no meu lugar eu faria: eu abortaria, pois eu não teria condições de tê-lo e assim seria melhor para ele e para mim (pílulas). 
K Ela deveria se responsabilizar pelo que fez. Mesmo que voltasse a estudar depois.

$\begin{array}{cl}\begin{array}{c}\text { Grupo B } \\ \text { G }\end{array} & \begin{array}{l}\text { Ela deveria se ausentar um ano do colégio e não abortaria e até o primeiro ano de vida do filho } \\ \text { e depois ela retomaria os estudos e trabalharia meio período. } \\ \text { Ela deveria se ausentar durante um ano do colégio, e, não deveria abortar, e, até um ano de } \\ \text { vida, ela retomaria o s estudos, e trabalharia meio período. } \\ \text { Jane deveria se ausentar durante um período do colégio até o bebe se estruturar (cerca de } 1 \\ \text { ano) e depois ela retomaria os estudos e trabalhando meio período. O bebê ela poderia colocar } \\ \text { em uma creche. }\end{array} \\ \text { G } & \begin{array}{l}\text { Gonseguir ajuda, continuar os estudos, se não conseguir cuidar do filho, mandá-lo a um } \\ \text { C }\end{array} \\ \text { orfanato, etc. } \\ \text { Grupo A }\end{array}$

Ainda pensando no mesmo caso, Ricky, que tem 18 anos, acabou de entrar para o curso de engenharia em uma conceituada Universidade. Para criar um filho, ele tará de abandonar os estudos e começar a trabalhar em alguma outra função. O que ele deve fazer ou propor para Jane?

Grupo E Rick não precisaria parar de trabalhar apenas mudar o seu cotidiano para um que beneficie não M somente o pai mas a Jane também.

C Chegamos à conclusão de que dá para conciliar o trabalho e a criança se eles tiverem boa vontade.

$\begin{array}{cl}\text { Grupo D } & \\ \text { C } & \text { Ele deveria ajudar Jane, trancar a faculdade ou então trabalhar. } \\ \text { A } & \begin{array}{l}\text { Ele deveria continuar os estudos à noite e Jane deveria trabalhar e mais tarde ela amamenta o } \\ \text { bebê e recomeça os estudos. }\end{array} \\ \text { B } & \begin{array}{l}\text { Eu não sei responder essa questão porque é preciso de outra opinião (no caso um casal de } \\ \text { namorados) pra responder isso. }\end{array} \\ \mathrm{K} & \begin{array}{l}\text { Ele deveria trabalhar meio período e estudar à noite. Propondo a Jane a parar de estudar até o } \\ \text { bebê nascer. }\end{array}\end{array}$

Grupo B Ele continuaria na Universidade, arrumaria um emprego de meio período e ajudaria a criar o

$G \quad$ filho e contaria com a ajuda dos pais.

Ele continuaria na Universidade, arrumaria um emprego de meio período, e, ajudaria a criar o

A filho, e, contaria com ajuda dos pais.

R Ele continuaria na Universidade, arrumaria um emprego de meio período e ajudaria a criar o filho. Também poderia pedir ajuda dos pais.

$\begin{array}{ll}\text { Grupo C } & \\ \text { C } & \text { Deveria continuar os estudos, arranjar um emprego melhor. } \\ \underset{T}{\text { Grupo A }} \text { Um período trabalha e o outro estuda. }\end{array}$

A "pílula do dia seguinte" age da seguinte forma: se a fecundação ainda não tiver ocorrido, ela dificulta o encontro do espermatozóide com o óvulo; se a fecundação já houver ocorrido, ela provocará uma descamação do útero, impedindo a implantação do zigoto. Vocês consideram a pílula do dia seguinte um método abortivo? No seu país imaginário ela seria liberada ou proibida?

GrupoD Sim, eu acho. Sim, seria proibida pois se o zigoto se fixa no útero após 30h, quando você C tomasse a pílula, você descamaria o útero e mataria o embrião formado. 
Depende do caso. Mas seria permitida (estupro, e no caso de um acidente da camisinha a

B menina que no caso se for uma menor de idade, aí com a presença dos pais ela poderia tomar).

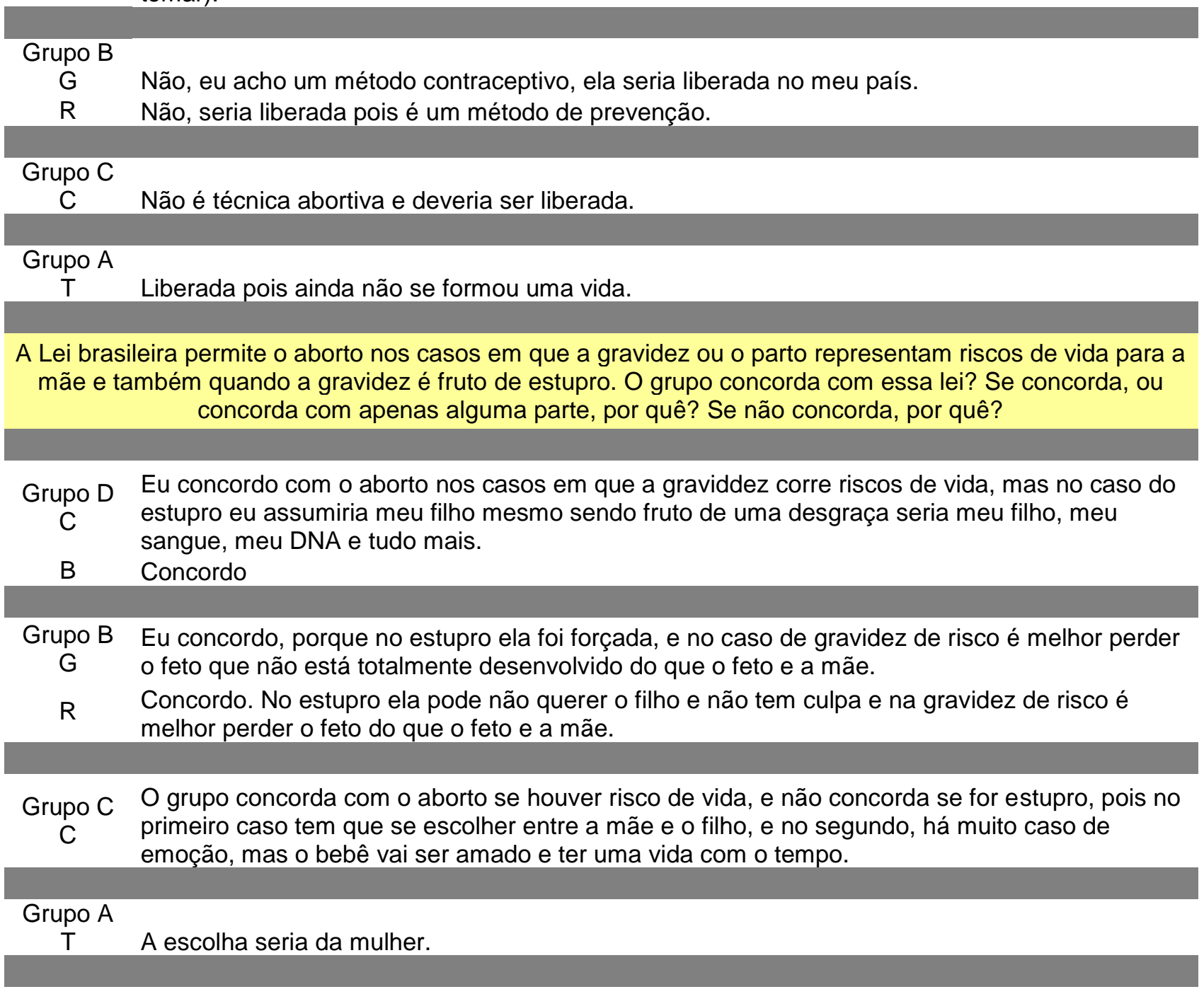

\section{Anexo III}

\section{Transcrição Grupo A}

3'25',

1. T: [lê a questão 5]

2. T: Eu acho que quando o espermatozóide encontra o óvulo mesmo porque é o primeiro indício mais ou menos de você ficar grávida.

3. G: eu acho que é no momento em que o zigoto se fixa no útero, porque aí a gente já pode ter a confirmação de que a pessoa vai ficar grávida, ou está né...

4. M: eu considero quando o bebê começa a se formar.

5. T: [lê a questão 6]

6. T: eu acho que a pílula do dia seguinte é liberada, porque é um arrependimento mais ou menos da pessoa...eu acho que...é, é liberada...

7. G: eu acho que seria liberada porque...não sei, eu não sei muito de gravidez mas, pelo que eu entendo, eu acho que ainda não deu tempo de se formar um bebê e uma vida lá... 
8. M: eu não considero um aborto porque foi muito pouco tempo pra formar um... bebê

9. T: [lê a questão 7]

10. T: eu concordo porque estupro é... é uma coisa que não é da sua vontade...não tem porque você ficar grávida...você... é...eu acho...

11. G: eu acho que aí é um caso delicado que a gente tem que pensar mais...mas é... eu acho que aí deveria sim ser permitido o aborto porque é algo contra a sua vontade né...ou então... ou então ter o filho e se você quiser ter o filho... cuidar dele com amor porque ele não tem culpa do que ta acontecendo.

12. T: [lê a questão 8]

13. T: Depende da idade da mãe...se a mãe já tiver uma certa idade acho que... salva a vida do bebê

14. G: eu acho que a do bebê porque o bebê seria...a nova geração... humana...

15. M: eu acho que a mãe porque a mãe é...ela viveu mais do que um bebê.

\section{0'46',}

16. G: [lê a questão 1]

17. T: ah, eu acho que assim, não pode ter aborto...eu acho que é contra...mano, você ta matando uma pessoa...

1'40',

18. G: [lê a questão 1]

19. T: eu acho que o aborto tem que ser impedido porque você está matando uma criança...é um ser humano de qualquer jeito, é um bebê, é uma vida, você não pode matar, é assassinato isso, eu acho um absurdo...

20. M: eu acho que deveria ser [risos] eu continuo achando que deve ser [risos]

21. T: um assassinato, é ilegal não pode matar uma criança!

22. G: eu acho que o aborto em algumas circunstâncias é...pode ser favorável ou não...por exemplo, foi o que o professor disse...se uma mãe está prestes a morrer por causa do aborto eu acho que aí deveria ser uma prática proibida, quer dizer, concedida, porque de qualquer jeito uma pessoa iria morrer, então eu acho que aí no caso o aborto seria favorável, mas na maioria das vezes, quando faz por consciência eu acho que aí é errado porque é a vida de uma pessoa que você ta matando e... é isso...

1'32',

23. G: [lê a questão 1]

24. T: eu acho que o aborto não pode ser legalizado porque de qualquer jeito você ta fazendo um assassinato, você ta matando uma pessoa...não pode...é um absurdo isso...eu acho que nunca pode se matar um bebê, uma vida...qualquer coisa...é um ser humano de qualquer jeito...

25. M: eu acho que é assim...o aborto é... não devia ser legalizado mas...tem muita gente que aborta não por não querer ter filho nem nada disso...é porque pode ter sido estuprado ou qualquer coisa assim.

26. G: eu acho que o aborto é ilegal porque é uma vida né... e...mas tem casos por exemplo como se a mãe for morrer por ter o filho aí eu acho que seria favorável abortar...mas assim num contexto geral eu seria contra porque é uma vida e poderia ser você. 
27. T: [lê a questão 2]

28. G: eu chamaria médicos e cirurgião...ahn advogados também...

29. T: eu chamaria...médico é...uma pessoa que entendesse do assunto, um advogado...alguma pessoa que soubesse o que estava falando...

30. M: eu chamaria um médico, porque ele entende bem do assunto.

31. T: [lê a questão 3]

32. G: eu acho que ela deve arcar com as consequiências, porque ela sabia, tinha consciência que a camisinha não é $100 \%$ segura, eu acho que talvez deveria ser... e... eu acho que como foi uma coisa que ela escolheu, ela não foi estuprada, ela não tinha risco de vida...ela teria que ter o filho porque é uma vida...enfim...é isso...

33. T: eu acho que... nesse caso ela não deveria fazer o aborto porque...é uma coisa que... não vai fazer...porque ó 16 anos, ela é muito inteligente, ela, sei lá, ela poderia deixar o filho com a mãe enquanto ela estudava e depois ela trabalhava, eu não sei, mas acho que ela não deveria recorrer ao aborto agora.

34. T: [lê a questão 4]

35. G: ele escolhe um período de estudo e outro de trabalho, porque ele não pode largar os estudos mas também não pode deixar a Jane na mão né...

36. T: eu acho que...ele não poderia parar de estudar porque ele tem que estudar porque ele pode arrumar um emprego melhor...ele pode ter um emprego que pode dar mais dinheiro pra ele e pra Jane mas, num sei né, depende do momento...

37. M: eu acho que ele devia começar a trabalhar sim, porque ele tem que sustentar, o filho é dele, mas não parar de estudar porque ele podia ter uma carreira estudando.

\section{Transcrição Grupo B}

10'16"

1. G: [lê a questão 5]

2. R: acho que logo quando fecunda o óvulo, porque tipo...uma célula, qualquer célula é uma vida, qualquer célula respira, acho que é isso...

3. A: quando ela...quando ela o que?

4. R: acho que desde a fecundação, porque...

5. A: acho que desde que ela sente que o atraso, não quando ela começa a sentir...não entendi a pergunta.

6. R: quando que começa a vida de um bebê?

7. G: [lê novamente a questão]

8. A: eu acho que... no momento quando o espermatozóide encontra o óvulo

9. R: eu acho que é isso mesmo porque, se a célula respira...ela é uma vida...

10. G: eu também concordo...

11. [pausa...]

12. A: Por quê?

13. R: Porque eu acho que se uma célula respira ela tem vida...

14. G: Também acho

15. G: [lê a questão 6]

16. G: eu acho um método abortivo

17. R: é...

18. A: eu também acho, mas acho que pode ser permitido 
19. R: acho que pode ser permitido nos mesmos casos do aborto

20. A: ah, eu não acho que nos mesmos casos do aborto...é também...porque assim tipo vai...é pílula do dia seguinte...você não pode viver tomando ela porque é perigosa, mas eu acho que é assim, se, vai que ela não usou a camisinha ou se a camisinha estourou e não tinha outra, eu acho que ela tem que tomar sim pra caso ela não fique grávida, mas acho que não tem os mesmos...como chama...mesmos

21. R: métodos...

22. A: não métodos, não...

23. R: riscos...

24. A: não...mesmos sintomas que tem o aborto entendeu?

25. R: tipo, eu acho que devia ser sob as mesmas condições do aborto, entendeu? Porque se a gente concorda que é um método abortivo, então tem que ser igual ao aborto...

26. A: eu não acho, porque é um método abortivo mas é um método abortivo que assim, não tem tanto risco...

27. R: eu acho que não é um método abortivo...

28. G: eu também não acho...eu acho que é um método contraceptivo...um método que previne...

29. R: é

30. A: é, é melhor do que um método abortivo

31. R: porque se for um método abortivo

32. A: vai ter que ter as mesmas leis...

33. R: é

34. A: ah, então é um método que previne

35. R: qual que é a pergunta?

36. G: [lê novamente a questão]

37. [pausa]

38. G: no meu país ela seria liberada

39. A: no meu também

40. R: no meu também

41. [pausa]

42. G: posso ler a outra?

43. G: [lê a questão 7]

44. G: eu concordo

45. A: eu concordo

46. R: eu concordo...é, aquilo que a gente pos na outra...

47. G: e por quê?

48. A: porque no....estupro, a mulher não teve escolha...ela foi tipo forçada, foi obrigada a fazer tudo, foi violentada o que é muito óbvio... então se ela não queria aquele filho foi porque ela foi estuprada...eu concordo...

49. G: e no caso do risco, o que seria melhor, um feto ou uma mulher? [inaudível]

50. R: se o feto...se o feto... se a mulher morrer o feto vai morrer, mas se o feto morrer a mulher não vai morrer..

51. G: eu concordo

52. A: eu também concordo...

53. G: que nem a minha tia tentou duas vezes engravidar, tipo uma das vezes o feto não agüentou e abortou sozinho entendeu?... ela não teve que tomar nada.... [inaudível]

54. R: melhor só o feto do que o feto e a mãe... 
55. [pausa]

56. G: [lê a questão 8]

57. R: acho que...é muito complicado...porque, se a mãe morrer, o bebê também vai morrer...

58. G: é verdade...

59. R: porque o bebê não tem como viver se a mãe morrer...a não ser que ele esteja prestes a nascer e possa ficar...

60. G: em uma incubadora...

61. R: é...

62. G: mas aí ele ficaria sem mãe...e se o pai não assumisse?

63. A: não mas sei la', o médico...

64. R:[inaudível]

65. A: é, adotou...

66. G: mas às vezes sofre mais...

67. A: é mas se a mãe morreu, G., hm

68. A: ah, não sei qual é mais importante

69. G: eu acho que as duas são importantes

70. A: os dois são importantes, não tem como escolher qual é mais importante

71. R: mas se ela morrer o bebê também morre...

72. A: na maioria dos casos, mas tipo se ela estiver lá no parto...

73. R: se o bebê for embrião ainda e a mãe morrer ele também morre...

74. G: as duas são importantes... as duas são importantes só? Por quê?

75. R: se for um feto e a mãe morrer, o feto também morre

76. G: a mãe...morrer...o feto...o embrião...também morrerá...também morrerá...

77. R: e se for mais velho...

78. A: se tiver tipo na hora do parto e a mãe não agüentar...

79. R: tem bebê que nasce com 5 meses, 4 meses... se der para salvar a vida do bebê, eu acho que o bebê é mais importante...

80. G: que que eu escrevo?

81. R: se der para salvar a vida do bebê, mesmo colocando dentro de uma incubadora, a vida do bebê é mais importante... eu acho que a mãe também pensa isso.

82. A: também...

\section{5'49',}

83. G: o que vocês acham sobre o aborto?

84. R: ah meu, é muito complicado... quando você pensa que...

85. A: eu acho que é errado abortar...

86. G: eu acho que depende do caso, porque é assim, tem gente que complica toda a vida por causa do aborto, ou por causa que tá grávida, tipo, digamos assim pais que podem expulsar a pessoa da casa...

87. A: não teve cabeça para fazer, então, agora assuma...

88. G: agora assuma...

89. R: e se foi obrigada a fazer...?

90. A: duvido muito...

91. G: a gente não ta falando de uma pessoa em especial, a gente ta falando de todas em geral...

92. A: ta! 
93. G: e...eu acho que é assim, pode estragar a vida de uma menina ficar grávida...então o aborto seria mais recomendado...é melhor legalizar o aborto e..., porque aí....

94. R: [inaudível]

95. R: ah meu devia ter um tipo um julgatório, mas rápido, por exemplo o máximo de 1 mês de aborto, depende da situação da pessoa, entendeu? Porque se for uma pessoa que não tem condições de criar o filho, porque ou não tem cabeça pra criar o filho ou não tem condições financeiras?

96. A: dá pra alguém

97. G: mas daí A. , pode...é...sabe, é uma coisa do seu corpo, sabe? Não é qualquer coisinha, não é um cachorro que você comprou que vai dar...

98. A: ta mas se vai abortar é quase a mesma coisa que você dar pra alguém

99. G: ah, mas eu acho que vai estragar a vida de uma menina, e eu acho que devia ser legalizado....tudo bem que vai tar matando...eu não sei se eu acho que deveria ou não...porque, pelo não...

100. R: eu acho que depende da situação da pessoa... se for uma pessoa que sabia das conseqüências o que ia acontecer se ela...num...como é que fala...

101. G: preservativo

102. R: é não usasse preservativo, ela sabia disso, acho que daí ela tem que assumir, mas se foi uma pessoa que foi estrupada, opa falei errado, num falei? Tudo bem

103. G: eu acho que assim, por um lado eu acho que não deveria porque você ta matando uma pessoa...uma vida...por outro lado...

104. R: [inaudível]

105. G: e daí é uma vida...por outro lado acho que devia ser legalizado porque pode estragar com a vida de uma pessoa.

106. A: eu acho que tipo assim vai...estuprar..tipo vai...estuprou e ela fica grávida aí é legalizado abortar...agora meu...agora todo mundo praticamente no país inteiro sabe que tem vários modos de prevenir o aborto...postos de saúde dão camisinhas de graça...então acho que vai pela pessoa

107. R: mas acho que é melhor abortar do que jogar na rua, jogar no lixo, no esgoto...

108. A: verdade

109. G: verdade

110. G: mas então ó, a primeira...vamos fazer a primeira questão?

111. G: [lê a questão 1]

112. R: acho que devia ser permitido se a pessoa provar que não tem condições de criar o filho

113. G: é... ela tem razão, devia ser permitido quando a pessoa não tem...

114. R: condições financeiras de criar o filho

115. G: porque o filho é caro...precisa de fralda...

116. A: não concordo muito...

117. G: ahn?

118. A: eu não concordo muito.

119. R: pode doar né...

120. G: deveria ser...legalizado em circunstâncias assim...que devia provar que ela não teria saúde mental, não teria condições financeiras, acho que deveria ser, mas só com essas condições...

121. R: acho [inaudível] acho que tá bom, por exemplo, se for ter um risco ou se a pessoa for estuprada... 
122. G: também acho

123. A: então, mas essas razões já tão aí, no Brasil também...

124. R: então, isso que eu falei...

125. G: eu acho que o aborto deveria ser legalizado por essas coisas e por causa de condições financeiras também...e de saúde

126. R: ah, de saúde já é né...

127. G: não...

128. R: é sim, se há risco...

129. G: mas saúde mental

130. R: ah...

131. G: pode escrever?

132. R: não vai esperar a A.?

\section{8'13',}

133. A: continuando...

134. G: assim, eu acho que o aborto, a gente deveria fazer que o aborto pode ser legalizado

135. R: nos casos em que já é legalizado.

136. G: nos casos como os do Brasil e com a saúde mental da pessoa... a pessoa pode... a minha vó por exemplo...ela ela não queria ter minha mãe, ela começou a bater em todo lugar...pegava a panela e batia na barriga...minha vó chegou a pular de um ônibus pra perder...e não perdeu...pois é... acho que deveria ser legalizado, mas tipo...só quando tivesse risco pra saúde é...e quando desse risco à saúde mental da pessoa...

137. R: eu assisti um filme, um seriado...Lost, uma menina tipo ela tava grávida, aí o marido dela abandonou ela e a mãe dela tava internada...aí ela decidiu que ela ia...primeiro ela queria abortar...aí depois ela decidiu que ia doar pra adoção...só que aí ela foi num avião viajar e o avião caiu... é filme, porque o avião caiu e ia morrer todo mundo, do jeito que o avião caiu... só que aí ela continuou sobrevivendo numa ilha, com um monte de sobreviventes...aí ela...o filho dela nasceu e ela começou a cuidar do filho e aí, num dá pra doar porque ela ta na ilha...daí ela passou a gostar do filho... é tipo porque ela ia dar a luz e ela ia doar direto, ela não ia nem ver...é complicado né...

138. A: muito complicado

139. R: e o que a gente vai colocar na primeira?

140. G: que o aborto será...poderá ser legalizado em condições de...se tiver risco à saúde da mãe, risco à saúde mental da mãe e se ela for estuprada...

141. R: você concorda A.?

142. A: concordo.

143. A: vai ficar muito tempo sem ninguém estar falando né

144. G: ...mas as mulheres... poderão... as mulheres...só poderão abortar quando...tiver risco à saúde...

145. A: quando for uma gravidez de alto risco...

146. G: ahan...

147. [pausa]

148. G: de alto risco...colocar a saúde...da mãe...a saúde mental da mãe...em risco...

149. A: e quando houver caso de estupro

150. G: ahan...

151. A: a segunda... 
152. R: coloquei o aborto deverá ser legalizado em caso de estupramentos, quando a mãe estiver correndo riscos ou se a pessoa não tiver condições psicológicas de dar à luz.

153. G: eu coloquei ó, o aborto será legalizado mas, as mulheres só poderão abortar quando tiver risco à saúde, uma gravidez de risco, colocar a saúde mental da mãe em risco e qundo a mãe for estuprada.

154. A: eu quase a mesma coisa que a $\mathrm{G}$.

155. G: [lê a questão 2]

156. R: médicos

157. G: ginecologista

158. A: pediatra

159. G: num sei

160. R: é né

161. G: psicólogo...psicólogo

162. R: e, eu acho que pessoas, ricos e pobres

163. A: mas só podem ser...profissionais...

164. R: ah, profissionais, ta... acho que é só né?...

165. G: assistente social

166. R: é, acho que é só né, profissional é só...

167. A: é...

168. G: [lê a questão 3]

169. R: aí é complicado hein

170. G: Ô! Ela tem 16 anos, ela quer ser médica... se ela abandonar os

estudos...ela deveria estar em qual...no segundo? No primeiro

171. R: no segundo, 15 é o primeiro...

172. G: segundo...então ela...segundo ano..que estrutura você tem para passar na faculdade de medicina?... e será que o pai dela...será que o namorado dela ia assumir o filho?

173. R: [inaudível] um amigo...o irmão de uma amiga...ele tem uma namorada e a namorada dele engravidou...e tem gente na faculdade dele...que ele ta fazendo educação física...ele tem 21 anos...tem gente na faculdade dele, deve ter a mesma faixa etária tipo que...engravidou...e eles não se casaram mas estão assumindo o filho juntos...

174. G: eu também conheço uma pessoa que é do rio de janeiro...que ela engravidou, o namorado não vai assumir, a mãe ta doente, o pai ela não conh...o pai dela mora aqui em são Paulo e a madrasta nem se importa, então ela não tem ninguém para contar...e ela ta assim sabe...com 16 também...16, 15...

175. A: eu acho que assim...assim, porque assim...normalmente as jovens ficam grávidas muito cedo e até que ela foi até que uma...não foi numa boa idade...mas melhor do que as outras, pensando...

176. R: acho que não devia nem ser com 16 anos

177. A: ah mas daí ela decidiu com o namorado dela...

178. G: não, não foi irresponsabilidade, porque ela usou camisinha

179. A: ela usou camisinha

180. G: esse negócio de estar pronta é de cada uma pessoa...

181. A: é verdade, é de cada...

182. G: é de cada uma, pra você pode ter sido irresponsabilidade dela,mas pra ela pode ter sido certo, e tipo...

183. A: porque assim, ela, eu duvido que ela vai querer engravidar, que ela vai querer abortar o filho...num sei... 
184. R: é muito complicado também porque ela pode pensar que ela ta matando alguém...

185. G: sim ela quer ser médica...como ela vai abandonar os estudos e... acho que ela deveria continuar estudando...

186. A: e abortar?

187. G: não...

188. R: mas num tem jeito ela tem que cuidar do filho, não pode...

189. G: deixa com a mãe

190. A: deixa com a mãe, é verdade...tipo sei lá...durante alguns meses ela fica meio ausente do colégio depois ela tenta recuperar...

191. R: peraí, Bruno, aqui no 3 é obrigatório ela largar os estudos?

192. Prof: porque não vai dar tempo, ela vai ter que trabalhar e vai ter que largar os estudos...

193. A: mas e se ela deixar o filho

194. G: com a mãe e trabalhar meio período?

195. Prof: ta, vocês podem pensar em opções então...

196. R: então mas é obrigado,...por exemplo, vai...um mês que ela não pode sair de casa, alguma coisa assim?

197. Prof: o que é importante pensar é o seguinte, seria muito mais difícil ela continuar estudando...imagina que de repente o horário que ela vai trabalhar ela não consegue, não dá tempo de estudar...

198. G: não então, mas ela pegaria um trabalho de meio período como lojista alguma coisa...nos primeiros meses, quando passasse de 7 pra 9 ela pararia de estudar, porque também poderia por em risco, porque já estaria na hora de nascer...então de 7 a 9 ela pararia de...

199. A: calma, mas você tem que pensar também se o colégio em que ela estuda permitiria que ela fosse grávida pro colégio...

200. Prof: ta, pensa em todas as possibilidades...

201. A: eu acho que assim ela tinha que se ausentar um pouco do colégio durante os meses de gestação...

202. R: e depois ela repete

203. A: ta, repetia, mas depois ela retomava os estudos entendeu?

204. R: então, repetir a série que ela perdeu, melhor que ficar sem, já que é o sonho dela...

205. G: é...é porque ela também tem o trabalho...

206. A: eu acho que ela devia contratar alguém...particular...

207. R: mas se ela não tem condições?

208. G: mas como tem condições de pagar o colégio?

209. A: pode ser bolsista

210. R: pode ser escola pública

211. A: publica permite

212. G: então eu acho que assim, se ela não teria condições, então ela poderia continuar na pública... que permite...mas se fosse na particular...aí sim...

213. A: eu acho que ela é da particular...

214. R: é, eu também acho...mas por exemplo, eu não tenho condições de pagar um professor particular pra mim, e eu estudo numa escola particular, é diferente...

215. G: daí como ela começaria a trabalhar, ela poderia fazer aquele supletivo

216. A: não dá G., porque tipo sei lá, ela trabalha, e vai amamentar o filho, e vai cuidar do filho, como que ela vai se virar? 
217. R: Acho que dá pra mãe dela, deixa a mãe dela cuidando, tipo

mamadeira, deixa ela amamentar, lógico que é bem melhor... acho que ela devia parar esse ano por exemplo...até ter o filho e depois repetir a série...

218. A: também acho, porque pelo menos assim ela ia se formar e ao mesmo tempo ia estar cuidando do filho dela, ou da filha...

219. G: ela...iria...

220. A: deveria...

221. G: deveria?

222. R: ahan, ela deveria ir à escola até 6 meses...

223. G: não, ela deveria se ausentar durante 1 ano do colégio...

224. A: e não deveria abortar né...

225. G: é...A., deixa eu por aqui... quando o filho nascesse ela voltaria à série que ela perdeu...

226. A: não não, esperava mais um tempo, porque tipo sei lá...

227. R: até o bebê se estruturar um pouquinho

228. G: mas daí ela vai perder muito tempo de...

229. R: ué e daí, mas o bebê naõ pode por exemplo, com 1 mês, ficar sozinho sem a mãe

230. A: é melhor, tipo, ela se atrasar um pouco nos estudos e depois ela

retomar do que ela não cuidar do filho dela...

231. G: e não abortaria e...até o filho ter 1 mês...

232. R: não 1 mês é pouco

233. A: 1 mês é muito pouco!

234. G: vocês falaram 1 mês...

235. A: não, estar estruturado

236. R: é muito pouco pra ela ir pra escola, é muito pouco pra ela largar o

filho, tipo até o bebê se estruturar, sei lá...

237. G: tipo, até...1 ano...

238. A: isso

239. R: porque daí já pode colocar numa creche

240. G: ...filho...e depois ela voltaria a estudar...

241. A: ela retomaria os estudos...

242. R: e trabalhando meio período

243. G: e trabalharia meio período.

244. [pausa]

245. G: [lê a questão 4]

246. G: eu acho que é assim, se ele gostar dela e se ela gostar dele, eu acho que ele deveria propor em casamento, mas se não tiver amor, acho que ele deveria cuidar do filho sim, mas não precisaria casar...

247. R: acho que ele podia trancar a faculdade

248. A: eu acho que assim, porque assim, eles podem estar namorando há 1 ano, mas acho que para eles se casarem é uma decisão muito assim, porque depois ele pode chegar e não gostar mas ainda continuar criando o filho sabe...e tipo eu acho que ele não deveria abandonar os estudos assim...

249. R: acho que ele deveria tipo...um curso de engenharia será que é meio período também? Num sei...

250. G: assim, ele sairia do...ele arranjaria também um trabalho de meio período também...ele deveria pegar um emprego de meio período também...pra ajudar...e fazer o curso também...

251. R: e eles podiam pedir ajuda dos pais... 
253. R: acho que ajudaria bastante, o salário dela, o salário dele, o dinheiro que ele ganha, mais o dos pais...

254. G: o dos pais...

255. R: os dois pais, os pais dela e os pais dele...

256. G: então a gente coloca assim, ele continuaria na universidade...arrumaria um emprego de meio período... e ajudaria a criar o filho...

257. R: também com ajuda dos pais

258. G: e contaria com a ajuda dos pais...

259. R: e se não der tempo dele estudar, porque engenharia [inaudível]

\section{Transcrição Grupo C}

\section{0'21',}

1. L: [Lê a questão 1]

2. D: Ó, Eu acho que o aborto só deve ser permitido quando a mãe tem risco de vida, mas quando, apesar de ser estuprada, a criança pode viver uma vida normal, no orfanato, tem várias instituições que... ajudam.

3. C: Assim....acho que pela minha opinião...eu acho que a criança tem direito de viver né...porque nós não somos ninguém para poder tirar a vida de outra pessoa...eu acho que isso é uma coisa que corre normalmente...a mãe acha que a criança é como se fosse um briquedo...qualquer coisa joga fora...

4. P: é e...pra qualquer coisa tem essas instituições do governo...orfanatos..essas coisas...que é só no risco da mãe poder morrer e ela não quiser ter o filho mesmo...

5. L: Ó pra mim...deviam fazer uma coisa realmente voltada ao aborto para poder aconselhar a mãe...falar o que ela devia fazer com o bebê...ou dar opção de trabalho coisa assim...como vai ser a vida da criança e a vida da mãe...e não assim tipo ...tentar só jogar o filho fora...

6. P: ou seja...ninguém tem direito de tirar a vida dos outros...

7. L: o que você pensa sobre o aborto $\mathrm{W}$.

8. W: Ah, só deve ser permitido em caso de risco de vida da mãe...porque há orfanatos...onde se pode deixar a criança lá...por que tirar a vida de alguém?

9. L: [lê a questão 2]

10. D: O L. qual é a pergunta?

11. P: tipo...seriam quais tipos de profissionais que você usaria para fazer esses abortos...

12. L: quais as pessoas que seriam mais especializadas...

13. P: mais especializadas...para fazer um aborto...

14. C: não...é que ajudarão a tomar essa decisão...

15. P: ah, tomar a decisão...

16. W: é, psicólogo...ééé médico..psicopedagoga

17. P: profissionais especializados nessa área

18. L: pra mim o primeiro de tudo seria procurar um médico porque aí, pô, vai saber se tem risco de vida se não tem...se abortasse mesmo que a mãe não queira, caso aborte se vai ter algum problema ou não...tipo...coisa assim...aí depois um sei lá...um psiquiatra...coisa pra aconselhar a mãe...no caso de estupro assim...as emoções mesmo...coisas desse tipo...

19. P: E as condições que ela vai ter no hospital ou no lugar em que ela vai fazer o aborto... 
20. W: É, porque não dá pra escolher qualquer um pra decidir sobre isso...

21. D: Ó, eu acho que é muito importante primeiro consultar um médico e depois consultar a sua família...conversar com a sua família para ver o que ela acha disso.

22. L: Muitas pessoas hoje em dia têm muita vergonha de falar sobre essas coisas...tipo...foi estuprada...aí não vai falar...vai ficar engravidada e vai ter um filho e vai esconder o filho, vai fugir de casa? Tem que falar pro pai, senão...mesmo que tome uma bronca, seja expulsa de casa, os pais vão ajudar de algum jeito...

23. P: É...expulsa de casa acho que...se um pai for fazer isso com uma filha que ta com um problema não é um pai...

24. C: Vamos pensar assim ó [lê a questão 3]

25. D: Eu acho que ela devia pedir ajuda para os pais e para os pais do cara que fez isso com ela...não ...o cara não teve nada...ele não fez nada demais...mas eu acho que os pais do namorado dela e os pais dela deviam ajudar...trabalhar...é como se fosse um meio filho de cada família...

26. P: É porque ela não fez o filho sozinha...

27. C: É que assim, na minha opinião eu acho que ela não pode ter medo dos pais né, porque os pais criaram ela tanto tempo você acha que só porque engravidou eles vão expulsar ela de casa? Acho que não né...E ela não precisa parar de estudar, ela pode estar indo pra escola...nninguém vai ficar assim...tirando da cara dela...também se tirar...[inaudível]

28. P: não mas isso daí ta falando que ela vai ter que trabalhar pra sustentar esse filho...

29. L: Pra mim, devia procurar todo tipo de ajuda possível...não tomar uma decisão rápida tipo...ah caramba...fiquei grávida e agora?...vou abortar o filho...pronto...não...primeiro procurar o máximo de ajuda possível...opinião formada e aí decidir o que vai fazer da vida...

30. P: Não o aborto, acho que volta o caso que tem instituições do governo que estão preparadas pra isso...

31. L: Sim, claro, daí se...qualquer coisa num puder cuidar do filho, não tem dinheiro, não tem condições de vida próprias pra ter o filho...aí deixa o filho num orfanato...numa instituição do governo, deixa pra outra pessoa cuidar...alguma coisa assim né, porque ajuda sempre tem em qualquer lugar...

32. D: Então, quando a mãe não tem dinheiro eu acho que ela devia botar no orfanato e visitar todo dia o filho pro filho ser dela e depois quando ela arranjar dinheiro, ficar mais crescida, acabar os estudos, ela pegar o filho e ficar com o filho para sempre...

33. P: Daí volta o negócio do país, num país em que nós fôssemos os governantes como na questão acima, deveriam criar instituições feitas para isso, para jovens que têm filhos e não têm como criar...

34. W: acho que deveria arrumar alguém para cuidar da criança por enquanto...

35. P: mas daí já tem dinheiro em volta...é um problema a mais...

36. W: tentar arrumar um trabalho e estudar ao mesmo tempo...

37. L: Assim, fica muito difícil estudar, cuidar do filho, tudo ao mesmo tempo...ainda por cima por causa dos problemas de dinheiro no meio...aí teria que né...uma babá provavelmente seria bem caro assim...uma coisa assim de babá pra cuidar do filho né ...uma ama... ficaria mais difícil pra mãe ter o filho do que colocar o filho no orfanato...

38. P: É...volta o problema da instituição. 
39. C: [lê a questão 4]

40. C: Eu acho que é isso né, colocar numa instituição por enquanto até eles ficarem prontos para ter um filho né, eles terem responsabilidade suficiente. Acho que...camisinha...ele já teve responsabilidade de usar camisinha né...mas eles não se preveniram o suficiente né...

41. P: mas isso é o acaso, não foi falta de...

42. D: Então eu acho que ele devia fazer a mesma coisa da Jane, pedir ajuda pra o máximo de pessoas e quando não der eles botarem no orfanato e visitar todo dia, isso que eu acho...

43. L: Pra mim ele devia tentar fazer o máximo possível para ajudar economicamente, financeiramente e paternalmente também, mas ao mesmo tempo continuar com a vida, tentar continuar com a vida o máximo possível, não pode tentar estragar a vida assim, não por um acidente...não que o filho seja um acidente...mas tentar...arranjar ajuda pra continuar seguindo...

44. D: Eu acho assim que ele não devia abandonar os estudos e pedir a máxima ajuda, mas nunca abandonar os estudos porque os estudos são a maior coisa que podem dar ao seu filho a felicidade...

45. W: Deixar a criança em algum lugar até mesmo como o D. falou num orfanato...continuar estudando até que ele termine os estudos e possa arrumar emprego pra cuidar da criança...

46. C: O negócio que o D. falou ta certo né, nunca largar os estudos né...porque se ele continuar os estudos vai ser mais rápido ainda de ele conseguir um bom emprego e conseguir dinheiro suficiente pra conseguir cuidar do filho...

47. D: então ta, agora a gente vai escrever aqui que ta pedindo pra gente escrever e entregar pro Bruno.

\section{3'59',}

48. W: Então, a decisão do grupo, qual foi a decisão do grupo?

49. D: A decisão do grupo foi assim ó, que o aborto só pode ser permitido quando a mãe tem risco de vida...

50. W: Você concorda, todo mundo concorda?

51. P: Concordamos

52. C: eu concordo

53. L: Assim, eu concordo também

54. D: então, escrevendo... escrevendo...

55. W: escrevendo...escrevendo...

56. C: eu acho que é assim né, se por exemplo ocorrer algo, é... risco de vida... como hoje existe já né é a mãe de aluguel né... pegar o embrião e colocar em outra mãe...para não ter esse problema

57. P: Não mas daí isso, isso pode acontecer quando o feto já está grande demais pra fazer essa... mããe de aluguel...

58. L: A mãe consegue descobrir antes de chegar o feto a um tamanho muito grande...consegue descobrir assim, que não ta menstruando...por exemplo... se tiver uma instrução boa [inaudível] aí dá pra descobrir que tem o filho já...

59. P: Sim, mas daí no caso seria [inaudível] de risco aí sim, se [inaudível] de risco usar a mãe de aluguel, mas acho que isso não é possível.

60. D: Se a mãe puder morrer eu acho que assim...o bebê ele ainda não teve nenhuma lembrança, ele ainda não teve nenhuma família, ele ainda não tem sentimentos, então, é melhor a mãe viver do que o filho morrer, o filho ficar dentro da barriga da mãe. 
61. L: então...o aborto deveria ser permitido só em caso de risco de vida...

62. D: Ta..a próxima... [lê a questão 2]

63. C: acho que...assim, o principal deveria ser o psicólogo e o médico né, o psicólogo pra dar orientação mental pra mulher né, pra ela não correr tanto abalo, e o médico né pra aconselhar o que será melhor...

64. P: [inaudível]

65. D: Eu também acho que a mulher assim, se a menina tiver coragem...eu acho que é bom também ela consultar a família dela pra ver o que que...pra dar mais boas ideias pra ela.

66. P: É...se ela esconder um problema desse é burrice...

67. L: O primeiro de tudo acho que devia ser família, amigos e um psiquiatra pra primeiro formar a mente, acima de tudo... e conseguir né, procurar...assim...

68. P: ou seja...psiquiatras, psicólogos, médicos...e família...amigos...não mas daí a família não porque aí ta escrito "profissionais"...ta escrito "profissionais"...

69. L: [inaudível]

70. P: não mas espera!... espera espera espera espera... que pergunta que é?

71. L: [inaudível]

72. P: 2 ...é a 2 né...

73. W: Dooois!

74. P: não não não não não não não! Espera! [interrupção] Cala a boca! Não, Desculpa! Deixa eu falar... ta dizendo...se você fosse o presidente...os profissionais que te ajudariam a tomar essa decisão, entendeu?...

75. L:ah sim... no caso...realmente os psicólogos, psiquiatras e médicos também...mas os...por exemplo...vereadores...também ajudariam...senadores, no caso...presidente pra saber as ideias deles também... daí se basear nas ideias deles pra tomar uma decisão também...basicamente é isso...

76. P: ta bom, escreve aí...profissionais como médicos, psiquiatras, psicólogos e também... [inaudível] de outros países...etc...

77. L: [lê a questão 3 - Jane]

78. D: eu acho né...que ela não pode largar os estudos...ela bota o filho no orfanato e ela visita todo dia pro filho ser dela, ela conversa...e ela não larga os estudos...pra ela ter tipo...pra ela arranjar uma profissão bem melhor e ter dinheiro pra botar o filho em casa...ao futuro...

79. L: e conseguir ajuda o bastante... assim...e também...pensar no que é bom pro filho também...

80. L: [lê a questão 4]

81. P: [inaudível] ele deveria continuar os estudos...

82. D: para arranjar um trabalho melhor pra ter o filho em casa no futuro...

83. P: isso mesmo...

84. C: pra ter mais dinheiro suficiente...pra poder criar o filho direito...

85. P: isso mesmo, acabou essa folha, passa pra próxima

86. C: professor, professor!

87. P: qual que é a próxima folha...ah ta aqui já...já tá aqui... não não é...

88. W: essa é a próxima folha...

89. [Barulho...]

90. P: [inaudível] já vai escrevendo...nessa próxima...pra gente não ter que repetir...

91. L: [1ê a questão 5]

92. P: num entendi...

93. C: pela minha opinião...

94. L: [inaud[ivel] 
95. P: ah ta...

96. C: pela minha opinião eu acho que o bebê começa a ter vida depois que ele sai do útero da mãe né, porque ele ta como os que vivem, ele ta vindo pra um novo mundo né...

97. P: eu...já não acho...eu acho que logo quando começa a se desenvolver o corpo...o zigoto...

98. D: então...eu acho que quando já ta desenvolvido...quando já faz um sinal assim... de vida...eu acho que é...não deve praticar aborto...só em caso de risco de vida...

99. P: não não não não não...mas... não...agora ele ta falando quando você acha que a vida começa para o bebê...

100. D: quando ele já começa a se desenvolver...pra mim é assim...

101. P: também acho...

102. W: a partir de que o espermatozóide encontra com o óvulo...porque a partir daí vai se formando o bebê que vai se desenvolver...

103. L: pra mim em qualquer momento que se possa detectar alguma vida, sabe? A vida científica...já é considerado vida o bebê...não importa o que...

104. P: certo...

105. C: é porque assim...eu acho que era melhor quando o filho sai da mãe porque é um jeito mais fácil de marcar a idade do filho né... mas isso em questão socialmente né...porque imagina pra mãe né...se ela usa o contato com o médico, como ela vai saber quanto que o filho já se desenvolveu dentro dela?... e por isso eu achei que era melhor por fora, entendeu?

106. P:eu não concordo......eu acho que é assim... não concordo porque dentro da barriga da mãe...logo depois que o espermatozóide encontra o óvulo...acho que daí já tem uma vida nova...

107. C: mas o médico sabe simplesmente a hora do contato do espermatozóide com o óvulo?

108. P: não...a hora...logo após a relação sexual...é... isso é muito...

109. C: mas ela vai saber simplesmente se ela, por exemplo... se ela fez o ato sexual...muitas vezes não pega na primeira vez... você acha que ela vai contando já os dias depois da relação?

110. P: Sim C., mas assim ó, ela sabe que ela fez o ato sexual...Daí quando ela descobre que está grávida, ela já sabe quando foi a vez... entendeu?

111. D: Ó, desculpa, eu acho assim, que quando o bebê já vai se desenvolvendo na barriga da mãe, ele já é considerado vivo...

112. P: Então ta, já entendeu...próxima...

113. L: [lê a questão 6]

114. W: Eu acho que isso é um método abortivo...você ta impedindo que um ser se desenvolva...

115. P: Eu não acho que seja um método abortivo, acho que é um método que você só pode usar em últimas causas e...no meu país seria permitido...

116. W: bem é...depende...se o espermatozóide não tiver encontrado o óvulo...

117. P: [inaudível]

118. L: Pra mim...assim...se os pais não tivessem pensado em se prevenir..aí eu acho que é um método abortivo...se os pais tivessem pensado em se prevenir...aí eu não acho que seja...no meu país seria liberado, eu acho...

119. P: Eu acho que assim...isso não depende...de...ser...quando se previne ou não... a pergunta quer dizer se é uma técnica abortiva ou não, independente da situação... 
120. L: Pra mim não chega a ser um método abortivo...pra mim não chega a ser vida ainda...

121. P: Concordo...

122. D: Eu também concordo...acho que tinha que ser permitida a pílula do dia seguinte...

123. C: É...se...nós falamos que o aborto não é permitido em questão de...por exemplo...estrupo...

124. P: Estupro!

125. C: Essas coisas...questão de...que são próprias...eu consideraria que essa pílula não era permitida...entendeu? Porque é a mesma coisa que fosse um aborto entendeu? A minha impressão é isso...

126. L: Então...mas pra mim...às vezes, muitas vezes a camisinha pode falhar, aí não chega a ser aborto...o cara tentou se prevenir a não chegar a vida ainda...

127. P: É eu também concordo...

128. W: é se a camisinha estourou...eles não vão ter culpa...

129. L: É como um acidente, não tinha como evitar isso...aí tem que tomar pílula do dia seguinte mesmo...tem que ser liberado...

130. P: Próxima... não...alguém mais quer falar?

131. D: Ó, eu concordo com o L., é isso que eu tenho a falar...

132. P: Então ó, nós concordamos que não devia ser liberada...

133. L: Não devia ser liberada?

134. P: Não, desculpa, deveria ser liberada... [inaudível] a opinião do C.. O C. acha que...Né C. ó se...isso daí não é um aborto...você não ta matando um ser...você ta impedindo que ele se desenvolva...impedindo...eu não acho que é uma técnica que deve ser ilegal...

135. C: é por esse lado também né, porque ...é... eu acho que continuo com a mesma opinião entendeu?

136. P: Então ta...Põe outra opinião aí L., que ele não permitiria...

137. L: [lê a questão 7]

138. P: Eu acho que é assim...ta, tudo bem...estupro...ela não quer ter o filho do cara mas...poderia ter...ela poderia deixar numas instituições...orfanatos...essas coisas...

139. D: Então, eu concordo com o P....devia deixar em algumas instituições ou talvez até criar...assim até criar você mesmo...

140. P: Eu acho que assim...toda mãe...independente do pai...ama o filho de uma maneira incondicional...

141. C: Eu acho que deveria tomar a pílula do dia seguinte...

142. P: Não, mas e se já passou as 72 horas...

143. D: Já passou...é...já passou as 72 ...você vai ter o filho ou não...você aborta ou não...

144. C: é...se não passou essas 72 horas ela ainda der tempo de pegar a pílula..eu acho que é esse negócio né...tem que deixar ele nascer né...ninguém tem direito de tirar a vida de um humano...

145. P: Aí ele já...aí se depois das 72 horas ele já se desenvolveu daí eu acho que ninguém tem direito de fazer isso...

146. W: Também concordo, querer abortar é uma [inaudível], mas também depende da pessoa...vai que ela tem o filho e talvez fique traumatizada

147. L: Assim...com o risco de vida tem que decidir entre a vida da mãe e a vida do bebê...daí é uma coisa difícil de decidir...ou o bebê vive ou a mãe vive...e na gravidez fruto de estupro vem muito coisa de emoção...a mãe não 
sente emoção pelo pai, o pai não sente emoção pela mãe, nenhum dos dois sente emoção pelo filho e aí acha que...o filho vai ser uma desgraça...aí eu não acho que seja uma desgraça... o amor vai crescendo com o tempo...

148. D: ó eu acho assim, dá pra amar qualquer pessoa [inaudível] mas assim...tudo bem botar no orfanato...ó..e...no caso assim de..risco de vida...acho que tem que abortar porque.... mãe teve mais vida do que o filho...eu acho que ela tem família, ela tem mais sentimentos tem mais coisas...

149. P: eu também concordo que devia abortar porque o bebê é um ser que ainda não viveu, não tem ainda seus sentimentos tão formados como os da mãe e...a mãe...eu acho que deveria abortar...

150. L: Aí a mãe...todo mundo diz que o bebê ele não lembraria quem é a mãe...mas daí...se a mãe não existir né...ele não vai lembrar da mãe e se o bebê não existir a mãe não vai ter o filho..não tem... aí tem que decidir...mãe ou filho...

151. P: Então. Qual que é a sua opinião?

152. L: Eu acho que devia ser a mãe a escolhida.

153. P: Ou seja, concorda, nesse caso, você concorda com o aborto...

154. L: Nesse caso, é o único caso que eu concordo com o aborto, na gravidez por estupro eu não concordo com o aborto.

155. W:Também concordo com o aborto...

156. L: Então a opinião, é, o consenso do grupo é de concorda com o aborto no risco de vida e não concorda no estupro?

157. D: Isso mesmo

158. W: Eu concordo

159. [Barulho]

160. C: o L. ta escrevendo ta, espera um pouco...

161. W: Então...

162. D: Então agora...número $8 \ldots$

163. P: número 8...última dessa...dessa página...

164. L: [lê a questão 8]

165. D: Ó, eu acho que a da mãe...a da mãe é mais importante do que a do bebê porque ela teve muito mais vida...ela teve muito mais mais amor...o filho ele ainda não teve a.... sua....ele ainda não teve seu amor...mas ele é vivo..mas ele não teve seu amor...então eu acho que a mãe devia viver e o filho devia morrer.

166. C: Ó eu tenho duas opiniões... eu acho que pela questão do filho né...porque ele vai ter um futuro né...ele que vai se desenvolver e vai fazer vamos dizer....futuro né...a mãe acho que porque...ela ...ela que fica se procriando né...daí ela tem mais tempo de se procriar mais...

167. P: Eu acho que assim...não acho que uma seja menos importante que a outra como diz...acho que é tão importante como...mas já como a mãe ela já viveu, já sentiu, já provou, já fez...daí ela...e o bebê ainda não...eu acho que a mãe, eu acho que ela que deveria sobreviver...o feto ainda...é só um feto.... a mãe já é uma pessoa já desenvolvida...

168. W: A mãe já possui uma vida social...o bebê não...a mãe tem familiares, parentes, o bebê tá como quem ainda não sente nada, não sabe de nada...

169. L: o bebê assim...é uma criação de tanto pai quanto mãe...se não tiver mãe...ele não vai ter lembranças, não vai ter amor...e aí vai ser muito muito...assim...complicada a vida do bebê...a mãe...se viver...pode digamos até ter outro filho...o outro filho vai viver...tudo mais... 
170. D: Então ó... a opinião do grupo é a seguinte... a mãe devia viver...

171. L: A mãe deveria viver porque ela tem uma vida já, o bebê ela ainda não tem uma vida, não tem lembranças, não tem amor não tem nada...

172. D: isso mesmo, ela já teve sentimentos...ela tem uma vida assim...e quando ela ta nesse negócio aí de mãe...ela ainda tem muito mais pra viver...e o filho também, mas ela assim...

173. C: Ela já consegue se cuidar sozinha e o bebê...se a mãe morrer quem cuida do bebê?

174. P: não, daí é outra coisa, daí tem outras pessoas...

175. D: ó então, mas eu acho assim, que tipo...já que ela já teve amor, sentimentos...ela já fez vários negócios e o filho ainda não teve esse negócio eu acho que a mãe devia viver...

176. P: Então a opinião do grupo foi...a mãe tem mais chances de viver...ou seja...a mãe tem hmm...a mãe que tem que viver...

177. P: Psor! Terminamos...

\section{Transcrição Grupo D}

6'00',

1. C: [lê a questão 1] Que que vocês acham?

2. A: eu acho que assim...quando a mulher ta em risco de morrer né ou senão estupro.

3. B: se o caso da mulher também estiver em risco a vida dela...ou em caso de estupro ou alguma doença assim né, problema mental essas coisas...que ela não pôde controlar nem nada...

4. C: acho assim que tipo, ta bom, se a mulher morrer sim, mas em caso de estupro não, porque mesmo assim eu assumiria meu filho...eu não abortaria, mesmo sendo fruto de uma coisa que eu não quisesse...mas eu não abortaria...

5. L: eu acho que assim, por exemplo, se nosso país fosse, vamos supor, o país imaginário fosse o Brasil...o Brasil tem, desculpa o termo...um bando de pobre que adora fazer filho...não mas é verdade...tem um monte de gente que tem um monte de criança...acho que o aborto, que nem o professor Bruno falou, o aborto não vai parar...mesmo clandestino ou não... acho que por meio lado, certo lado, o Bruno ta certo, porque se fosse, como é que chama...legislado...se não fosse proibido o aborto no Brasil, seria muito mais higiênico, ia sobreviver muito mais pessoas e não ia existir tantas coisas clandestinas... mas também tem aquele lado né...uma criança que acabou de nascer...mata uma pessoa...é uma coisa...

6. C: acho que assim, você fez agora você assume...se você transou com 10 agora você vai assumir os seus 10 filhos, não importa, porque, você que compre uma camisinha você que pegue, que mendigue na rua e compre uma, porque tem muitos meios de prevenir... e outra se você não criar você pode dar pro orfanato, pode por na creche, porque do mesmo jeito você transou com o seu namorado você já tem uma vida livre, você já tem um filho, vai estar se formando um embrião, é uma vida, é matar alguém, a mesma coisa.

7. A: então vocês concordam que tipo, só deve fazer aborto quando por exemplo alguma pessoa ta precisando ou tipo vai morrer, vai ter alguma doença com isso...

8. L: peraí eu concordo que o aborto tipo assim, ele podia ser sei lá, o aborto é proibido a não ser duas questões, é... o estupro ou sei lá..ta em risco de vida ou morte a mãe da criança, isso pode ser relacionado ao aborto... 
9. C: eu acho que não...acho assim também...em risco de vida sim mas estupro não...

10. A: é que como por exemplo...se

11. L: Ah, fala sério! O cara estupra a mulher...a mulher tem que carregar o filho do cara! Não!

12. C: não, mas é um filho teu também, L., mesmo assim, tem seu óvulo lá...

13. L: não mas é um filho daquele cara safado!

14. C: mas mesmo assim é o seu filho, você vai matar o seu filho?

15. L: olha, num sei, mas vamos supor, a gente pode usar a pílula do dia seguinte...

16. C: pra mim pílula do dia seguinte também é matar o seu filho...

17. L: Claro que não a pílula do dia seguinte o embrião ainda nem se formou

18. C: pra mim ele se formou a partir do momento em que o óvulo e o espermatozóide se unem pode ter uma vida la ${ }^{\prime} .$.

19. L: pra mim não...

20. A: K. o que que você acha disso? O que você acha disso?

21. K: eu, o que?

22. A: sobre o que elas estavam discutindo

23. K: acho interessante, principalmente o caso da L. o que ela falou ela ta certa, uma pessoa que foi estuprada ela não vai ter que carregar o filho do cara...meu uma pessoa ta andando assim na rua ela tem consciência e tudo mais aí ela é seqüestrada e estuprada, vai ficar grávida ela não tem que carregar por causa do bandido e tudo mais...

24. C: não mas pensa assim, mesmo assim, é um filho seu, mesmo sendo com uma pessoa que você não quer numa situação inoportuna que aconteceu é um filho seu, vai ter seu gens lá tem seu sangue lá tem seu dna lá tem seus óvulos lá...mesmo você não querendo é seu filho...

25. B: mas a pessoa não ta preparada pra isso...ainda não está preparada...se for uma menor de idade...nossa idade mais ou menos...ela não ta preparada o corpo físico e mental não ta nada preparado...

26. C: olha se fosse meu eu assumiria eu não ia abortar meu filho, não ia...

27. B: eu abortaria

28. L: então quer dizer que a resposta é assim, se nosso país existisse não existiria...seria proibido o aborto porque...

29. B: seria?

30. L: seria...seria proibido não seria? A não ser algumas questões, por exemplo o estupro...

31. C: eu não concordo...

32. L: professor, vem cá, fala sério, o estupro, o cara estupra a mina aí a menina fica carregando o filho do cara?

33. Prof: isso é discutível...

34. C: professor, pensa comigo...olha... tem seus genes lá...é seu filho do mesmo jeito..filho do cara que te estuprou e seu filho também...

35. L: claro que não...se você abortar 24 horas depois não é um filho...ainda é um embrião de nada...nem um embrião...nem se formou...

36. A: C., então você ta falando que nem agora, a gente vai ter...

37. L: eu concordo com a B., e se a menina tiver 12 anos...

38. C: assume, entendeu?

39. B: ela vai morrer no parto 
40. C: não B., não é necessariamente morrer no parto...tem muita criança hoje em dia que tem filho com $10 \ldots 10$ não, mas tipo $12,13,14$ anos que não morre no parto e tem o filho...

41. B: mas eu to falando assim...mas você tem risco de morrer...você não deixa de ter risco...

42. C: não

43. L: [1ê a questão 2]

44. L: acho que um médico...num sei...hehe

45. C: acho que eu chamaria um médico, um enfermeiro e um advogado

46. A: eu acho que eu chamaria um médico, uma enfermeira e um psiquiatra

47. L: eu acho que eu chamaria um médico, uma enfermeira, um psiquiatra, um advogado, uma professora e um cientista...

48. B: eu chamaria cientistas, médicos e médiuns, da área da medicina...

49. A: K. K. sua opiniãooo

50. K: eu chamaria um psiquiatra e um médico

51. C: não mas tipo pensa comigo, você não chamaria um enfermeiro K., por que?

52. K: num sei

53. C: o enfermeiro é a alma do hospital, é o enfermeiro que coordena tudo, tem coisas que o enfermeiro faz que o médico não sonha nem que existe... quem coloca sonda, médico ou enfermeiro?

54. K: enfermeiro

55. C: enfermeiro, quem cuida da mulher quando ta grávida quando nasce o bebê?

56. K: enfermeiro

57. C: quem faz tudo no hospital, limpa o hospital e ajuda as pessoas?

58. K: enfermeiro

59. C: quem opera?

60. K: médico

61. C: então, acho que teria que ter um enfermeiro pra ajudar o médico

\section{2'01',}

62. Prof: discute a 3 de novo então...

63. C: eu acho assim, que a Jane ela devia assumir a criança porque mesmo que foi uma coisa não prevista por ela... aconteceu, então agora ela assume, porque que nem a K. disse ela não foi obrigada a transar com ele...foi uma decisão conjunta... e eles sabiam dos riscos que poderia ter...depois...devia trancar a faculdade que nem a L. disse e procurar um trabalho pra poder sustentar o filho...pedir ajudar pros pais se não conseguir...

64. L: olha eu acho que a C. tem toda razão, porque a Jane...tudo bem eles se preveniram...só que eles eram novos também não sabiam....mas pô aconteceu...não foi desculpa, não foi estupro e não aconteceu nada...bom...o caso é...ele tem que se responsabilizar pela criança não só a mãe quanto o outro cara...o namorado dela...não precisa casar...só tipo...ser uma coisa boa entendeu...com o filho... e eu acho que eles deverão trancar os estudos e depois...mais pra frente quando quiserem voltar eles voltam...

65. C: sim, mas eu acho que assim... os dois são responsáveis, tanto o pai quanto a mãe porque aqui eles tiveram uma decisão conjunta, não foi o Ricky que obrigou você vai transar comigo hoje...então...os dois tem que assumir a 
responsabilidade...tranca os estudos...e outra...o aborto é como se fosse matar uma vida...

66. [pausa]

67. C: o que que você acha sobre a 3 K.? K. não acha nada ela é uma anta! B.

68. B: eu no caso dela, deveria abortar, eu ia abortar...

69. A: eu acho assim, que ela deveria... eu acho que ela deveria asumir e...tentar...parar um pouco os estudos...e assumir o filho!

70. L: ok, vamos pra 4, K. lê a 4

71. K: [lê a questão 4]

72. C: o que que você acha K.?

73. K: eu acho que ele devia parar o estudo dele pra trabalhar.

74. C: também acho...bem os dois fizeram...os dois assumem...tanto ele como a Jane deviam fazer algum plano pra vida porque não dá pra criar uma criança do nada...pedir ajuda pra família...condições...e juntos ter o fillho e assumir...claro...porque é responsabilidade dos dois.

75. L: eles se responsabilizam, beleza...eu acho que assim, ele não precisa parar com os estudos...sabe por que? Como ele ta entrando em um curso de engenharia agora...eu acho que ele deveria entrar em uma empresa pra fazer um estágio de manhã e fazer a faculdade a noite, o curso...porque eu acho que é assim é bem melhor ...ele vai conseguir um trabalho...não vai precisar parar de estudar...e por exemplo a Jane o caso da Jane acho que ela deveria assim... parar de estudar enquanto o filho não nasce...quando ele nasceu...amamentou...quando ele ta pronto assim....acho que daí ela pode voltar a estudar...

76. C: sim mas eu acho que ele tem que parar os estudos, porque como é que ele vai tipo...pensa comigo...ele tem a Jane.... Jane ta grávida ela não pode ficar o dia inteiro sozinha... é sair pra trabalhar às 7 da manhã e voltar às 10 da noite...ela ta grávida...precisa de alguém pra cuidar dela...entendeu?

77. A: eu acho que assim...ele deveria tentar fazer o que a L disse mas também...a Jane...eu acho que talvez ela pudesse ficar com os pais e os pais poderem ajudar durante esse estágio.

78. C: eu acho que a Jane podia trabalhar porque se ela fosse trabalhar por exemplo como atendente de lanchonete até ficar sei lá com 9 meses 8,7 ...ela não tem nenhuma ...nada pesado nada desse tipo...

79. A: ta eu concordo com você

80. C: ela pode estudar durante a gravidez dela também.

81. A: sim mas aí quando o filho começar a crescer muito eu acho que ela deveria parar por algum tempo...parar de estudar...

82. L: quando o filho tiver uns 7 meses pode parar... 7 ou 8 de gravidez... aí o filho nasceu aí ela pode amamentar ele e depois que ele estiver um pouco mais crescido pode deixar com os avós...

83. A: B sem comentários

84. L: então acabou, acabou

85. Prof: então agora tem essas

86. L: hahahahah

87. A: você adora fazer piada né professor...

88. [pausa]

89. A: e se eles não resolveram ter o filho e tem sem querer?

90. B: ah, aí é quando ela sentir que ta grávida...

91. A: hehehe 
92. C: eu acho que é no momento em que o espermatozóide encontra o óvulo, por que?...a partir daquele momento tem 200 milhões lá de espermatozóides...um deles vai sair e vai encontrar o óvulo e a partir daí ele vai ser fecundado e vai dar origem a uma nova vida, entendeu?... porque no momento em que o zigoto se fixa no útero...gente,sabia que vocês têm que ouvir?...ta, o zigoto se fixou no útero...ta bom, mas antes disso, ele vai ter que ser fecundado...

93. K: eu acho que é quando ele, quando o óvulo é fecundado, porque...

94. C: é, quando o óvulo é fecundado...aí vai ser fecundado e vai dar origem a uma nova vida...

95. B: eu já falei...quando o casal resolve ter o filho...

96. A: qual que é a pergunta, eu nem sei que pergunta é? Ah,brigada...

97. B: não, pra mim é quando eles comentam ah, e se a gente tiver um filho, pra mim esse é o começo da vida, já é o começo...

98. A: eu acho que é quando tipo...o sistema nervoso começa a se desenvolver no embrião...

99. C: quando você transou com o seu namorado...encontrou o óvulo com o espermatozóide...depois vai...de uma semana...você ta grávida...ainda não ta desenvolvido o seu embrião...vai, ainda um óvulo sei lá...não ta totalmente desenvolvido, quer dizer que você não ta grávida? Não tem um filho lá dentro?

100. A: não sei como te explicar...

101. C: ou só quando ele tiver um mês aí você vai falar...não agora eu to grávida...

102. A: eu acho que no momento em que...

103. L: ultra-som

104. A: eu acho que no momento em que você descobre que você ta grávida...eu acho que é esse momento em que você começa a ter um filho...e L isso daqui é seu...

105. C: mas A, pensa comigo...eu posso descobrir que eu to grávida depois de dois meses...

106. A: por isso mesmo...quando você não sabe...é complicado...

107. C: depois de 2 meses...no dia em que eu transei com o meu namorado eu já vou estar grávida, já vou ter um filho dentro de mim...

108. A: e como você sabe...e se vocês usaram camisinha?

109. C: A, a camisinha pode estourar sabia?

110. L: é bem provável que isso aconteça

111. C: não é $100 \%$ seguro...então quer dizer que...só vou descobrir quando o meu embrião se desenvolver...quando tiver um mês meu filho vai ter um bracinho e só vou descobrir aqui...saber que ele acabou de nasceu naquela hora?

112. A: não, mas eu to falando que talvez...

113. C: mas ele nasceu naquela hora?

114. A: ah, eu acho que talvez só quando você descobre, porque até lá você não sabe...

115. C: mas mesmo assim...você não sabendo já tem uma coisa dentro de você se formando que vai dar origem a uma nova vida...ou melhor, já tem uma nova vida lá...

116. A: ta concordo

117. L: quando o grupo...ele considera...não quando a pessoa

sabe...descobre...quando considera... você acha que o espermatozóide quando

encontra o óvulo, você acha que já é uma vida?

118. A: $\operatorname{sim!}$ 
119. L: então!

120. A: ah, eu tava entendendo assim...como se quando...

121. L: ah, então não responde...

122. A: ta bom...mas quem vai responder é a $\mathrm{K}$ no papel

123. B: não, minha vó...

124. L: ta gravando ainda... espera, eu leio a segunda-feira

125. C: não peraí eu não terminei a primeira

126. L: eu vou começar a cantar aqui...lalala... canta...vamo lá... [lê a questão 6]

127. C: ou seja matando o seu bebê...eu acho assim...por exemplo você disse que você considera o momento de vida quando o zigoto se fixa no útero, correto?

128. L: correto...

129. C: então, se ele se fixou no útero e você usar a pílula do dia seguinte vai descamar o seu útero, ou seja, o zigoto que tava implantado vai morrer, vai desimplantar, vai ser destruído, ou seja, aquela vida que você disse que teria...vai pro espaço...

130. L: a pílula do dia seguinte são só depois de 48 horas...você acha que depois de 48 horas o zigoto vai se fixar no útero?

131. C: sim, o Bruno disse que se fixa depois de 30 horas...ele fixa depois de 30horas...

132. L: ta bom ta bom...

133. C: então você vai ter uma vida...vai lá e você vai matar uma vida....

134. L: ta bom eu ainda acho que isso é diferente...

135. C: por exemplo...sua mãe, ela ta grávida...ela transou lá sem camisinha

136. L: eu não acho e pronto

137. C: não, mas tem que discutir...quer dizer que só porque você não acha...ah ta bom eu não acho e ponto? Tem que dar uma razão pro que você acha...

138. L: eu já dei

139. C: fala

140. L: de novo?

141. C: eu não ouvi...

142. L: ah, já ta gravado aí

143. C: fala

144. L: o que? C, C você é louca? O mp3 nem é seu!

145. A: o que você acha B? Sobre a pílula do dia seguinte

146. B: eu acho que assim...depende do caso, eu até deixaria...eu aceitaria no meu país...mas assim seria no caso de estupro...eu se no caso a família...a família estiver assim.... menina esclarecer com o namorado e que a família [inaudível] o que realmente aconteceu...na presença dos pais daí ela poderia tomar a pílula do dia seguinte...uma boa causa lógico

147. A: você acha então assim... a pílula do dia seguinte só poderia ser utilizada por causa de meios extremos e quando por exemplo ocorre alguma coisa mas sempre com a presença dos pais de uma autoridade em cima dessa pessoa é isso?

148. B: uma pessoa responsável

149. A: e se a pessoa tiver 18 anos, e aí, ela vai ter autoridade sobre ela mesma, mesmo assim você acha que os pais deveriam estar juntos, presentes, sabendo sobre o acontecimento? 
150. B: não, aí ela não pode mais tomar a pílula...só se fosse uma menor de idade, abaixo de 18 anos

151. A: mesmo que ela for estuprada você acha que...

152. B:não a, aí é um caso extremo...

153. A: ah, ta bom então... e você $\mathrm{K}$ o que você acha?

154. K: eu acho que é um método abortivo e eu não acho que deveria ser liberado...

155. A: por que?

156. K: porque eu sou contra o aborto

157. A: K, uma explicação, por favor, uma explicação!

158. L: hahahahhaha, A

159. A: uma explicação K...

160. K: não, porque se você toma a pílula do dia seguinte você ta matando entendeu?

161. A: mas tem que ter uma explicação porque, ententeu?

162. K: então, porque eu acho isso, porque eu sou contra o aborto e é um método abortivo

163. A: talkei...e você...tem mais alguma coisa a dizer?

164. L: não, eu concordo com todo mundo

165. A: então você concorda que deve ou não...

166. L: concordo A!

167. A: ta bom ta bom...

168. L: lê a outra

169. A: to sem a folha...

170. L: [lê a questão 7] eu concordo com os dois porque eu acho assim, o aborto, o estupro, eu falei a mesma coisa várias vezes...o caso, coitada da menina, ela é estuprada...ela não precisa carregar o filho...sei lá, depois de 24 horas sei lá pode acontecer...ela pode abortar num sei...quem sabe...e eu acho que a outra parte do...em caso de vida...eu acho que isso não prec...eu acho que isso é um...é um é...

171. C: eu acho assim, tudo bem...em caso de gravidez com o parto com risco de vida tudo bem pra mãe...doente mental, como a B disse... mas acho que mais assim...você sendo estuprada tudo bem...é fruto de um estupro de uma coisa que você não gostou... depois o seu vai...tudo bem não é bom pra você, não é uma coisa que você concordou...mas mesmo assim eu acho assim...a partir daquele momento aquilo é uma vida e mesmo você não querendo é um filho seu...você não tem que abortar ele...

172. A: mas $\mathrm{C}$, como você vai explicar pro seu filho assim, ah filhinho você nasceu de um estupro do papai!

173. C: eu explicaria pra ele que eu fui abusada, estuprada e que eu não ia matar ele...eu decidi ficar com ele pra criar porque ele também é fruto de mim...explicaria isso pra ele...

174. A: mesmo que fosse assim uma pessoa que você totalmente odeia...a pior pessoa do mundo!

175. B: se ela foi estuprada então odeia o cara né... ela não vai ser estuprada e amar o cara depois

176. A: não, então faz assim, um cara que você já odeia antes de acontecer isso

177. B: antes ou depois vai odiar de qualquer jeito A.

178. L: assim, C, você vê o maníaco do parque, ó o papaiii, ó o papaiii... 
180. A: na televisão né, olha o papai na televisão!!!

181. B: mas eu concordo com a lei brasileira...

182. C: K

183. A: sua opinião

184. K: eu concordo com a lei

185. A: porqueeee...

186. L: nossa, a $\mathrm{K}$ falando você se emociona...a $\mathrm{K}$ as palavras dela...

187. A: são curtas e fortes!

188. L: nééé

189. A: ta bom então vamos dar um tempo pra K pensar no assunto

190. L: ta bom agora vamos falar

191. C: peraí

192. A: peraí falta a C escrever e a K pensar...

193. B: ela concorda com todo mundo

194. L: agora...vamos ler a oitava...qual das vidas você.... peraí.....[lê a questão 8]

195. L: eu acho que é a do...beee..mãe...be...mãe...num sei, hehe

196. C: eu acho assim se você for ver, se você é mãe e você ta esperando seu filho se for entre a sua vida e a do seu filho com certeza também a maioria das mães vai optar pela vida do filho igual eu, eu optaria pelo meu filho viver e eu morrer, porque eu preferia botar ele no mundo...

197. B: eu também

198. C: você cria um elo com o seu filho...

199. L: eu também...eu também

200. A: eu acho assim que na hora quem decide isso eu acho que é mais a mãe porque se a mãe decide morrer pelo filho eu acho que isso é um ato muito bonito pelo filho...que...

201. L: olha com certeza...se minha mãe morresse por mim eu ia amar muito mais ela...é com certeza um elo de mãe e filha...to até querendo chorar...

202. A: isso significa que você não ama tanto sua mãe como você amaria?

203. L:não, verdade...significa isso...vamos supor...se ela fizesse isso por mim com certeza eu ia ter muito mais afeto por ela...não ia falar mal nunca nunca falar mal dela...eu ia amar muito mais ela...

204. A: claro

205. L: com certeza

206. A: porque você não conheceria a sua mãe...você...ela morreria por você nascer...

207. L: e tudo o que falassem pra mim seria um ato bom não um ato ruim...

208. C: eu acho que assim... a mãe... ela sempre...pelo menos a maioria das mães...quando você ta grávida...você cria um elo com seu filho...você cria uma aliança com seu filho ou seja...você daria a vida por ele...então se fosse no meu caso...eu escolheria morrer...

209. B: pra mim todas as vidas tem o mesmo valor...não se mede o valor da vida...a gente não é ninguém pra medir o valor...se eu fosse a mãe eu com certeza daria a minha vida pela vida do meu filho...mas se eu fosse uma pessoa eu olhando assim tem que escolher quem vai morrer, a mãe ou o filho...aí eu já não ia saber entendeu, se for esse o tipo da questão...

210. A: por isso que eu acho que é assim...quem deveria escolher é a mãe e não a gente...eu acho que a mãe deveria escolher assim...se ela quiser morrer 
pelo filho ta bom, então você morre pelo filho, agora se a mãe não quiser não é nossa culpa...

211. B: porque a gente não tem nenhum direito de escolher quem é melhor ou pior... entendeu? é essa a minha opinião

212. A: K... a sua opinião

213. K: eu acho que não tem tipo...vida mais importante... as duas são importantes do mesmo valor...

214. A: então você concorda

215. L: bom, todo mundo concorda que... com certeza...o feto pra mãe é mais importante...com certeza...então cuide da vida nascendo...uma nova esperança pro futuro...os jovens... acabou!

\section{Transcrição Grupo E}

\section{7'25',}

1. C: alguém lê a pergunta? [lê a pergunta 1]

2. M: que que você acha?

3. G: eu acho que deveria permitir em qualquer caso.

4. C: por que?

5. G: porque a partir do momento em que uma mulher está para ter um filho e ela não quer ter esse filho ela tem o direito de abortar...

6. C: ta...

7. M: não, porque você ta matando um bebê, então é errado, como se matasse uma pessoa...só deveria ser permitido se a pessoa fosse estuprada ou se não tem condições de criar porque pra levar pra adoção também não adianta...mas não acho que devia legalizar porque senão todo mundo ia querer fazer sexo e ia querer abortar e não ta certo...

8. C: é, eu acho que...não é certo matar uma criança...que...vai ser uma pessoa né tipo...é um assassinato quase...só que antes de ela se desenvolver...mas tipo eu acho que em alguns casos poderia levar em conta tipo por exemplo...que nem ela falou...se for estuprada...e também se for estuprada muito pequena né tipo...porque às vezes foi estuprada e quer ter o filho, vai saber...mas às vezes não, às vezes, sei lá, é muito pequena...

9. M: não tem condições pra criar

10. C: ou se não tem condições mesmo, a criança vai morrer de fome aí...melhor nem ter né...

11. C: [1ê a questão 2]

12. G: eu chamaria médicos...ahn...cientistas...e pessoas que já tivessem abortado...legalmente ou não...

13. C: bom eu chamaria...é médico acho que todo mundo ia chamar né...pra ter uma ideia...mas também...acho que essas pessoas que fazem aborto legalmente também...pra ver a opinião delas ...e tentar considerar se a gente achar que pode levar em conta...então...é isso que eu acho...

14. C: então que profissionais você chamaria...?

15. M: médicos e pessoas que já passaram pela experiência e também psicólogos, porque pra entender, pra essas pessoas poderem se consultar, porque deve afetar muito o metabolismo e tipo a cabeça delas, elas devem ficar muito mal, porque matar um feto dentro dela, elas devem sentir uma coisa muito forte...então precisaria de ajuda pra superar esse problema...

16. C: [lê a questão 3] 
17. C: bom eu acho que ela deve... bom aqui não diz se ela é pobre ou rica...mas se ela for rica ela pode contratar uma babá, sei lá...e se ela for pobre, ah num sei, ela pode tentar pedir ajuda, porque abortar também num dá...vai...se ela gosta do cara...vai abortar pra que...acho que nem ele se sentiria muito confortável...

18. M: eu acho que ela devia conciliar as duas coisas...ela não tinha que parar de trabalhar totalmente, ela deveria pedir uma licença e tudo pra cuidar do bebê...e o namorado, marido dela continuar trabalhando pra ter uma renda pra cuidar do bebê...mas chegaria uma hora que depois o bebê crescesse, tudo bem e tal...quando ficasse um pouco mais velho tipo um ano ou dois...podia contratar uma babá por um determinado período e trabalhar tipo de manhã até de tarde ou de tarde até a noite, pra poder ficar um pouco com o bebê também pra ele não se sentir muito sozinho e não ter problema mais pra frente...

19. G: eu acho que, a partir do momento em que ela tá tendo uma criança, enquanto a criança ainda não se formou um feto especificamente, ela devia decidir se ela quer a criança ou não...se ela quisesse ela ia cuidar da criança exatamente como já foi dito e num sei o que...só que se ela não quisesse a criança ela abortava...

20. C: bom, a nossa conclusão foi que...se tivesse bem no comecinho...bom, mas aqui diz que foi um mês depois...foi um mês depois que ela descobriu que tava grávida, então já...bom então, a gente chegou a conclusão que, talvez não fosse muito adequado, mas se tivesse bem no começo ela que decidiria...

21. C: [lê a questão 4]

22. G: eu acho que ele devia propor pra ela um aborto porque eles ainda seriam muito jovens pra ter um filho ou ahn...eles poderiam tentar decidir ter uma vida juntos e procurar um novo trabalho e...se eles tivessem uma vida feliz assim, que bom...

23. C: bom eu acho que....ahn num sei... é meio complicado esse caso...se ele largar a universidade ele...pode acabar com a carreira dele mas....ah ele poderia sei lá...continuar na universidade e eles poderiam conciliar...tipo enquanto ela estudava de manhã ele cuidava do filho de manhã e enquanto ele estudava de tarde e ela cuidava do filho de tarde, aí ele se formava, eles podiam ganhar bem e dar uma boa vida pro bebê...

24. M: é, acho que eles tinham que se dividir, pra não ficar muito pesado pra nenhum dos dois... ele não precisaria parar totalmente de estudar...ele podia estudar de noite e trabalhar de manhã ou de tarde...e ela também, porque senão ficaria muito pesado pra um dos dois e também colocar uma babá seria muito ruim, porque se o bebê for criado por uma babá ele vai ficar com a cabeça totalmente...porque ele não vai poder ver os pais nunca se os dois estão indo trabalhar e estudar, eles nunca vão ter tempo pro filho então eles não vão poder ter uma relação boa, como uma família de verdade, então eles teriam que conciliar isso....ver direito pra poder não prejudicar nenhum dos dois, nenhum dos dois pode nem trabalhar mais nem perder nada...

25. C: então ta... Você propôs que deveria ser legalizado na primeira o aborto e a gente em alguns casos... é...nós discordamos um pouco...nós discutimos...discutimos...e chegamos à conclusão... que dependendo do caso...

26. G: chegamos à conclusão do que?

27. M: ser estuprada ou não ter condição de criar o filho

28. C: é...dependendo do caso pode ser permitido...se for estuprada... ou não tiver condições de criar...aí...poderia levar em conta...é...e pensar se é adequado...

29. G: dependendo do caso o aborto seria permitido?... 
30. C: ah, se for estuprada ou não tiver condições de criar...peraí, poderia levar em conta e o que...

31. M: poderiam pensar no caso de fazer um aborto...

32. G: quando sofresse um estupro ou o que?

33. C: é ou não tiver condições de criar...

34. M: porque não adianta nada ter o filho e jogar

35. C: é, não adianta o filho não ter como se cuidar... depois manda pro orfanato e a criança fica com a cabeça meio...

36. G: acho que em caso de estupro devia ser obrigatório...

37. M: não obrigatório, [inaudível]

38. C: não, e se a pessoa quiser...

39. G: ai, vocês não esperam!

40. C: ai, onde é que você ta? vai lê, lê inteira vai!

41. G: nós discutimos e chegamos à conclusão de que dependendo do caso o aborto deve ser permitido, quando houver estupro ou falta de condições de criar o filho...

42. C: é...só isso...

43. [pausa]

44. G: nós estamos exatamente há 16 minutos gravando...16 minutos! Cara!!!

45. C: que fique bem claro que foi o $\mathrm{G}$. que falou...

46. G: não é para citar nomes!

47. C: e se eu falei...

48. G: ah fica quieta...

49. M: permitido ou não no país imaginário...quais os tipos de profissão que vocês chamarão para ajudar a tomar essa decisão?

50. C: foi unanimidade médico...medico todo mundo falou...

51. M: e pessoas experientes que já passaram por essa situação...também chamariam psicólogos porque a cabeça da mulher depois de passar por esse essa situação deve ficar toda embaraçada...

52. G: então que que seria...médico... já tivessem histórico de aborto...

53. C: psicóloga

54. G: psicólogo...e psicanalista...

55. C: e tipo a mulher do filme...

56. G: então fala a mulher do filme, filha!

57. C: também as pessoas que fazem aborto nos outros...quem faz parto é parteira, e quem faz aborto...?

58. G: [assovio]

59. M: pára!

60. C: agora a três...

61. M: [lê a questão 3]

62. C: a conclusão foi que ela pode abortar ou não mas que não seria muito certo abortar...

63. M: não porque ele falou...

64. C: que que você acha nessa?

65. G: essa aqui?

66. C: é, que que você tinha falado?

67. G: que o cara com quem ela transou é muito feio! É...to brincando!

68. M: dá aqui, vai!

69. G: perae! Eu acho que, ainda que já tenha feito um mês a partir do momento em que ela está grávida, levando em consideração que eles não planejavam 
engravidar e provavelmente por enquanto ela ainda não quer começar a trabalhar, ter um filho e cuidar da família e bláblábla', eu acho que eles deviam abortar, mas caso eles aceitem a ideia de cuidar do bebê, mudar de trabalho, pagar, cuidar da própria vida e blábláblá, eles podem não abortar e ter o filho...

70. C: ta, então a conclusão é tipo, depende deles, o que eles vão querer, mas que seria mais adequado não abortar...

71. M: ta, então a conclusão, como eles já são quase adultos, eles deviam pensar muito bem antes de tomar qualquer decisão porque eles estariam matando um feto, filho deles, entendeu? Então, se eles se gostam assim de verdade eles deviam cuidar do filho juntos e conciliar os estudos, sabe, dividir cada um... que quando eu cuidar do filho...pra não perder a vida particular deles porque... com 18 anos eles ainda não...com 16 anos eles num sabem ainda muito bem o que eles querem...então eles deviam não parar de estudar, porque é importante para a formação deles, então eles deviam conciliar um com outro pra não perder em nada a juventude deles, porque eles também precisam disso...

72. C: então o mais correto seria...

73. G: e aí, o que vocês estão escrevendo?

74. C: que o mais correto seria...

75. G: oooo maiiiiisss corretttooooo... tá, e é isso aí... diga alguma coisa...alguma coisa...[ruído] já acabei de responder to esperando elas acabarem de responder...

76. Prof: já dei a outra folha pra vocês? Acabando essa vocês tem essa aqui pra responder

77. G: ta brincando com a nossa cara né professor?

78. C: pensei que já tinha acabado, puxa! Agora fala eu agarantio! Eu agarantio!

79. M: G.!

80. C: deixa ele!

81. M: [lê a questão 4]

82. M: bom a gente discutiu e chegou à conclusão de que ele não deveria parar de trabalhar por causa do bebe...os dois deviam conversar pra não prejudicar ambas as partes, então eles deveriam...o Ricky deveria trabalhar em certo período e estudar de noite e também...enquanto no horário dele cuidar do filho a Jane poderia estudar continuar os estudos dela porque também não seria justo ela também ter que parar de estudar para cuidar do bebe enquanto ele faz as coisas dele...mas também um dos dois vai ter que trabalhar pra poder dar um bom futuro pro filho...

83. C: ta então vamos por... é... chegamos à conclusão...chegamos à conclusão...de que dá pra conciliar os dois...

84. M: você não vai responder?

85. G: responder o que? Tem resposta, uau!

86. C: a gente chegou à conclusão que dá pra conciliar os dois se tiverem boa vontade...

87. G: que?

88. C: dá pra conciliar o trabalho e a criança se eles tiverem boa vontade

89. M: ta, cinco [lê a questão 5]

90. C: cala a boca!

91. G: uaaahhh [bocejo] deixa eu ler, deixa eu ler! Então eu vou ler o próximo!

92. C: bom eu acho que o inicio da vida começa quando o zigoto se fixa no útero e começa a se dividir né, porque aí já começa a formar o embriãozinho... que que você acha?

93. G: eu acho que só a partir do momento em que...quequeé? 
94. C: é essa aqui

95. G: eu sei que é essa...então deixa eu responder!é... acho que o início da vida de uma pessoa humana só ocorre depois que ela já nasceu e saiu do útero...

96. M: eu acho que no momento já que o espermatozóide encontra o óvulo, e o zigoto se fixa no útero, já se pode considerar um bebê, porque nesse momento ele já está sendo formado então mesmo você matando o bebê nessa época é um erro, sabe? Porque você vai estar matando de qualquer jeito, porque ele já está sendo formado, entendeu?

97. C: deixa ele ler a....

98. G: não me chama de idiota! Não me chama de inútil! [lê a questão 6]

99. M: dá o gravador! Não eu não proibiria a pílula do dia seguinte porque ah, num sei, ela é um método de ajudar a menina a não ficar grávida assim, tipo, ela pode tomar diariamente antes da gravidez ou quando ela quisesse, se pra ela ou pro parceiro dela a camisinha não for um método que pra eles... eles não gostem na hora de fazer o ato sexual...éuma boa ajuda pra eles...então não seria proibido...não é um aborto assim...certamente...eles poderiam ter o ato e não estar matando o bebê...não ta sendo a criação de um bebê ainda...

100. G: eu acho que o gravador ta gravando...

101. C: bom eu acho que se o espermatozóide ainda não encontrou o óvulo, eu acho que ainda não é um aborto, porque só ta impedindo que tenha um filho, que nem a camisinha, é a mesma coisa...mas se já provocou a ...se já aconteceu a fecundação...bom, acho que também ainda não...só ta impedindo a implantação do zigoto tipo....ainda não ta impedindo...ta impedindo só a fixação...se ele já se fixou aí seria um método de aborto...e eu não acho um método de aborto...e eu acho que eu liberaria pra impedir que acontecesse gravidez indesejada...

102. [pausa]

103. G: eu acho que bem ou mal seria um método abortivo porque, no seu efeito mais demorado seria diretamente no útero, o que já é um pedaço vivo e...mas acho que ela também poderia ser liberada assim como os outros métodos de aborto...

104. M: dá aí!

105. G: o apressado come cru!

106. M: [lê a questão 7]

107. M: bom eu acho que...eu concordo...porque se apresentar risco de vida pra mãe vai ser um problema pro filho, porque mesmo que o bebê nasça, ele vai ficar sem a mãe e vai ficar o pai...então perder a mãe assim...

108. G: fala no buraco filha!

109. M: perder a mãe assim só por causa de um parto assim com risco deve poder fazer o aborto, eu acho...e também quando há o estupro deve poder fazer porque a pessoa não teve culpa desse ato que foi feito nela.

110. G: eu acho que ele ta $\operatorname{xxxxxxxxxx}$, ficando $\operatorname{xxxxxxxxxxxx..}$

111. C: aguarde um instante...tanananana... 


\section{Anexo IV}

\section{Anexo IV Grupo A}

Cinza: partes do argumento que não pertencem àquela categoria

Negrito: a garantia está explícita

"c": o aluno não disse o argumento, mas concordou com ele

* Subargumentos ramificados da refutação do argumento anterior

\begin{tabular}{|c|c|c|c|c|c|c|}
\hline \multirow{2}{*}{$\begin{array}{l}\text { Aluno e } \\
\text { Enunciado }\end{array}$} & \multicolumn{5}{|c|}{ Argumentos ou Asserções } & \multirow[b]{2}{*}{ Padrão Moral / Valor } \\
\hline & Dado (dado que...) & Conclusão/ Asserção & Garantia (já que...) & Qualificador & $\begin{array}{l}\text { Refutador (a menos } \\
\text { que...) }\end{array}$ & \\
\hline $\begin{array}{l}\mathrm{Ge}, \mathrm{Me} \\
\mathrm{Te}\end{array}$ & \multicolumn{2}{|r|}{ A escolha seria da mulher } & & & & $\begin{array}{c}\text { Moral Intuitiva / Direitos } \\
\text { da Mulher }\end{array}$ \\
\hline T6 & $\begin{array}{l}\text { é um arrependimento mais } \\
\text { ou menos da pessoa }\end{array}$ & \multirow{3}{*}{$\begin{array}{l}\text { a pílula do dia seguinte é [deve ser] } \\
\text { liberada / seria liberada }\end{array}$} & $\begin{array}{l}\text { o arrependimento pode ser } \\
\text { suficiente para livrar a mãe do } \\
\text { onnus de ficar grávida }\end{array}$ & & & $\begin{array}{l}\text { Moral Emotiva / } \\
\text { Arrependimento e } \\
\text { Isenção de } \\
\text { Responsabilidade }\end{array}$ \\
\hline $\begin{array}{l}\mathrm{Ge}, \mathrm{Me} \\
\mathrm{Te}\end{array}$ & \multirow{3}{*}{$\begin{array}{l}\text { ainda não deu tempo de se } \\
\text { formar um bebê e uma vida / } \\
\text { foi muito pouco tempo pra } \\
\text { formar um... Bebê / pois } \\
\text { ainda não se formou uma } \\
\text { vida }\end{array}$} & & \multirow{3}{*}{$\begin{array}{l}\text { a pílula do dia seguinte age } \\
\text { nesse tempo, o que garante que } \\
\text { ela não mata uma nova pessoa }\end{array}$} & & & \multirow{2}{*}{$\begin{array}{c}\text { Raciocínio Moral } \\
\text { Deontológico / Limites da } \\
\text { Vida - Conceitos (ação } \\
\text { da pílula) }\end{array}$} \\
\hline G7 & & & & & & \\
\hline M8 & & $\begin{array}{l}\text { não considero [a pílula do dia } \\
\text { seguinte] um aborto }\end{array}$ & & & & $\begin{array}{c}\text { Raciocínio Moral } \\
\text { Deontológico / Limites da } \\
\text { Vida - Conceitos (ação } \\
\text { da pílula) - Regras e } \\
\text { Aplicabilidade }\end{array}$ \\
\hline T10, G11 & $\begin{array}{l}\text { porque estupro é uma coisa } \\
\text { que não é da sua vontade / } \\
\text { é algo contra a sua vontade }\end{array}$ & $\begin{array}{l}\text { em caso de estupro a mulher deve } \\
\text { poder abortar / concordo [com a lei } \\
\text { brasileira] / aí [caso de estupro] } \\
\text { deveria sim ser permitido o aborto }\end{array}$ & $\begin{array}{l}\text { não tem porque você ficar } \\
\text { grávida / ninguém é obrigado a } \\
\text { assumir riscos de uma situação } \\
\text { da qual não se tem controle }\end{array}$ & $\begin{array}{l}\text { aí / no caso de } \\
\text { estupro }\end{array}$ & \multirow[t]{2}{*}{$\begin{array}{l}\text { ou então ter o filho e } \\
\text { se você quiser ter o } \\
\text { filho }\end{array}$} & $\begin{array}{c}\text { Moral Emotiva - } \\
\text { Raciocínio Moral } \\
\text { Deontológico / Acidentes } \\
\text { e Não-Responsabilidade }\end{array}$ \\
\hline $\mathrm{G} 11^{*}$ & $\begin{array}{l}\text { ele não tem culpa do que tá } \\
\text { acontecendo }\end{array}$ & $\begin{array}{l}\text { [a mãe] deve cuidar do filho com amor } \\
\text { no caso de estupro, caso ela queira ter }\end{array}$ & $\begin{array}{l}\text { ninguém pode perder a } \\
\text { oportunidade de nascer em }\end{array}$ & $\begin{array}{l}1 \text { aí / no caso de } \\
\text { estupro }\end{array}$ & & $\begin{array}{l}\text { Moral Emotiva - } \\
\text { Raciocínio Moral }\end{array}$ \\
\hline
\end{tabular}




\begin{tabular}{|c|c|c|c|c|c|c|}
\hline & & o filho & $\begin{array}{l}\text { virtude de uma situação da qual } \\
\text { não tem controle/culpa }\end{array}$ & $\begin{array}{l}2 \text { se você quiser } \\
\text { ter o filho }\end{array}$ & & $\begin{array}{l}\text { Deontológico / Acidentes } \\
\text { e Não-Responsabilidade } \\
\text { - Cuidado Parental }\end{array}$ \\
\hline G22 & $\begin{array}{l}\text { porque de qualquer jeito } \\
\text { uma pessoa iria morrer }\end{array}$ & $\begin{array}{l}\text { em caso de risco de vida da mulher } \\
\text { [ela deve poder abortar] o aborto deve } \\
\text { ser uma prática concedida }\end{array}$ & $\begin{array}{l}\text { a mãe tem o poder de escolher } \\
\text { entre a vida dela e a do novo ser } \\
\text { que carrega }\end{array}$ & $\begin{array}{l}\text { [em caso de risco } \\
\text { de vida da } \\
\text { mulher] aí...se } \\
\text { uma mãe está } \\
\text { prestes a morrer }\end{array}$ & & $\begin{array}{l}\text { Raciocínio Moral } \\
\text { Consequencialista / Valor } \\
\text { Relativo da Vida - } \\
\text { Direitos da Mulher }\end{array}$ \\
\hline G22, G26 & \multirow{3}{*}{$\begin{array}{c}\text { você tá matando uma } \\
\text { pessoa/ porque você está } \\
\text { matando uma criança; é um } \\
\text { ser humano de qualquer } \\
\text { jeito; é um bebê; é uma vida; } \\
\text { é assassinato isso / é a vida } \\
\text { de uma pessoa que você tá } \\
\text { matando / porque é uma } \\
\text { vida }\end{array}$} & \multirow{6}{*}{$\begin{array}{c}\text { o aborto tem que ser impedido / o } \\
\text { aborto deveria ser proibido / não devia } \\
\text { ser legalizado / aí [o aborto] é errado / } \\
\text { o aborto é [no país imaginário] ilegal }\end{array}$} & \multirow[t]{2}{*}{$\begin{array}{l}\text { matar é errado/ você não pode } \\
\text { matar; é um absurdo isso / }\end{array}$} & \multicolumn{2}{|l|}{$\begin{array}{l}1 \text { na maioria das } \\
\text { vezes } 2 \text { quando } \\
\text { faz por } \\
\text { consciência }\end{array}$} & \multirow{2}{*}{$\begin{array}{c}\text { Raciocínio Moral } \\
\text { Deontológico e Moral } \\
\text { Emotiva / Respeito à } \\
\text { Vida }\end{array}$} \\
\hline $\mathrm{T} 17$ & & & & & & \\
\hline $\begin{array}{l}\mathrm{Ge}, \mathrm{Me} \\
\mathrm{Te}\end{array}$ & & & \multirow{2}{*}{\multicolumn{2}{|c|}{$\begin{array}{l}\text { não se deve fazer aos outros o } \\
\text { que não gostaria que fizessem } \\
\text { com você }\end{array}$}} & & \multirow[b]{2}{*}{$\begin{array}{c}\text { Moral Emotiva / Respeito } \\
\text { à Vida }\end{array}$} \\
\hline G26 & poderia ser você & & & & $\begin{array}{l}\text { se a mãe for morrer } \\
\text { por ter o filho aí eu } \\
\text { acho que seria } \\
\text { favorável abortar }\end{array}$ & \\
\hline M25 & & & & & & Moral Intuitiva \\
\hline $\mathrm{T} 21$ & é um assassinato...é ilegal & & não pode matar uma criança & & & $\begin{array}{l}\text { Raciocínio Moral } \\
\text { Deontológico / Respeito } \\
\text { à Vida }\end{array}$ \\
\hline $\begin{array}{c}\mathrm{Ge}, \mathrm{Me}, \\
\mathrm{Te}\end{array}$ & & caso a menina fique grávida por & & & & $\begin{array}{l}\text { Moral Intuitiva / Riscos e } \\
\text { Responsabilidade }\end{array}$ \\
\hline T33 & $\begin{array}{c}\text { ela poderia deixar o filho } \\
\text { com a mãe enquanto ela } \\
\text { estudava e depois ela } \\
\text { trabalhava }\end{array}$ & $\begin{array}{c}\text { deve arcar com as consequencias / ela } \\
\text { teria que ter o filho / ela não deveria } \\
\text { fazer o aborto / assumir as } \\
\text { conseqüências }\end{array}$ & $\begin{array}{l}\text { os avós podem/devem ajudar de } \\
\text { forma intensa na criação de uma } \\
\text { criança pequena }\end{array}$ & $\begin{array}{l}\text { caso a menina } \\
\text { fique grávida por } \\
\text { acidente }\end{array}$ & & $\begin{array}{l}\text { Raciocínio Moral } \\
\text { Consequencialista / } \\
\text { Cuidado Parental }\end{array}$ \\
\hline
\end{tabular}




\begin{tabular}{|c|c|c|c|c|}
\hline G32 & $\begin{array}{c}\text { porque ela sabia, tinha } \\
\text { consciência que a camisinha } \\
\text { não é } 100 \% \text { segura }\end{array}$ & & $\begin{array}{l}\text { conhecimento dos riscos implica } \\
\text { responsabilidade }\end{array}$ & $\begin{array}{l}\text { Raciocínio Moral } \\
\text { Deontológico / Riscos e } \\
\text { Responsabilidade }\end{array}$ \\
\hline G32 & $\begin{array}{l}\text { foi uma coisa que ela } \\
\text { escolheu, ela não foi } \\
\text { estuprada, ela nãa tinha } \\
\text { risco de vida }\end{array}$ & & $\begin{array}{l}\text { tudo que é feito por vontade } \\
\text { própria deve ser assumido }\end{array}$ & $\begin{array}{c}\text { Raciocínio Moral } \\
\text { Deontológico / Livre- } \\
\text { apbítrio e } \\
\text { Responsabilidade }\end{array}$ \\
\hline G32 & é uma vida & & matar é errado & $\begin{array}{c}\text { Raciocínio Moral } \\
\text { Deontológico / Respeito } \\
\text { à Vida }\end{array}$ \\
\hline $\begin{array}{l}\mathrm{Ge}, \mathrm{Me}, \\
\mathrm{Te}\end{array}$ & & \multirow{5}{*}{$\begin{array}{l}\text { caso a menina fique grávida por } \\
\text { acidente ele [o pai] escolhe um } \\
\text { período de estudo e outro de trabalho / } \\
\text { ele não poderia parar de estudar / ele } \\
\text { devia começar a trabalhar sim (...) mas } \\
\text { não parar de estudar / um período } \\
\text { trabalha e outro estuda }\end{array}$} & & $\begin{array}{l}\text { Moral Intuitiva / Ambição } \\
\text { e Segurança Financeira }\end{array}$ \\
\hline G35 & $\begin{array}{l}\text { ele não pode largar os } \\
\text { estudos mas também não } \\
\text { pode deixar a Jane [a } \\
\text { gestante] na mão }\end{array}$ & & $\begin{array}{l}\text { a responsabilidade pelos } \\
\text { estudos é tão importante quanto } \\
\text { a paternidade }\end{array}$ & $\begin{array}{l}\text { Moral Emotiva - } \\
\text { Raciocínio Moral } \\
\text { Consequencialista / } \\
\text { Cuidado Parental - } \\
\text { Ambição e Seguranç̧a } \\
\text { Financeira }\end{array}$ \\
\hline G36 & $\begin{array}{l}\text { ele tem que estudar porque } \\
\text { ele pode arrumar um } \\
\text { emprego melhor...ele pode } \\
\text { ter um emprego que pode } \\
\text { dar mais dinheiro pra ele e } \\
\text { pra Jane [a gestante] }\end{array}$ & & $\begin{array}{l}\text { estabilidade financeira é } \\
\text { importante para constituir família }\end{array}$ & $\begin{array}{c}\text { Raciocínio Moral } \\
\text { Consequencialista / } \\
\text { Ambição e Segurança } \\
\text { Financeira }\end{array}$ \\
\hline \multirow{2}{*}{ M37 } & $\begin{array}{l}\text { porque ele podia ter uma } \\
\text { carreira estudando }\end{array}$ & & $\begin{array}{l}\text { a construção da carreira é muito } \\
\text { importante }\end{array}$ & $\begin{array}{l}\text { Raciocííio Moral } \\
\text { Consequencialista / } \\
\text { Ambiçãoo e Segurança } \\
\text { Financeira }\end{array}$ \\
\hline & ele tem que sustentar & & o filho é dele & $\begin{array}{c}\text { Raciocínio Moral } \\
\text { Deontológico / Cuidado } \\
\text { Parental }\end{array}$ \\
\hline
\end{tabular}




\section{Anexo IV Grupo B}

Cinza: partes do argumento que não pertencem àquela categoria

Negrito: a garantia está explícita

"c": o aluno não disse o argumento, mas concordou com ele

* Subargumentos ramificados da refutação do argumento anterior

\begin{tabular}{|c|c|c|c|c|c|c|}
\hline \multirow{2}{*}{$\begin{array}{l}\text { Aluno e } \\
\text { Enunciado }\end{array}$} & \multicolumn{5}{|c|}{ Argumentos ou Asserções } & \multirow[b]{2}{*}{ Padrão Moral / Valor } \\
\hline & Dado (dado que...) & Conclusão/ Asserção & Garantia (já que...) & Qualificador & $\begin{array}{c}\text { Refutador (a menos } \\
\text { que...) }\end{array}$ & \\
\hline R25 & $\begin{array}{l}\text { [a pílula do dia seguinte] é } \\
\text { um método abortivo }\end{array}$ & \multirow{2}{*}{$\begin{array}{l}\text { a pílula do dia seguinte deve ser } \\
\text { permitida nos mesmos casos do } \\
\text { aborto / devia ser sob as mesmas } \\
\text { condições do aborto }\end{array}$} & $\begin{array}{l}\text { as mesmas regras devem ser } \\
\text { aplicadas a casos semelhantes }\end{array}$ & \multirow{2}{*}{$\begin{array}{l}\text { nos mesmos } \\
\text { casos do aborto }\end{array}$} & & $\begin{array}{c}\text { Raciocínio Moral } \\
\text { Deontológico / Regras e } \\
\text { Aplicabilidade }\end{array}$ \\
\hline $\mathrm{R} 19$ & & & & & & $\begin{array}{l}\text { Moral Intuitiva / Regras e } \\
\text { Aplicabilidade }\end{array}$ \\
\hline A26 & $\begin{array}{l}\text { [a pílula do dia seguinte] é } \\
\text { um método abortivo }\end{array}$ & $\begin{array}{l}\text { eu não acho [a pílula do dia seguinte } \\
\text { deve ser permitida nos mesmos casos } \\
\text { do aborto] }\end{array}$ & $\begin{array}{l}\text { que não tem tanto risco } \\
\text { [quanto o aborto] }\end{array}$ & $\begin{array}{l}\text { nos mesmos } \\
\text { casos do aborto }\end{array}$ & & $\begin{array}{c}\text { Raciocínio Moral } \\
\text { Deontológico / Regras e } \\
\text { Aplicabilidade - } \\
\text { Conceitos (riscos do } \\
\text { aborto) }\end{array}$ \\
\hline $\begin{array}{l}\text { G16, } \\
\text { R17c, } \\
\text { A18c }\end{array}$ & & $\begin{array}{c}\text { [a pílula do dia seguinte é] um método } \\
\text { abortivo }\end{array}$ & & & & Moral Intuitiva \\
\hline \multicolumn{7}{|l|}{$\mathrm{R} 27$} \\
\hline $\begin{array}{l}\text { R29c, } \\
\text { G28, A30c }\end{array}$ & é um método que previne & $\begin{array}{l}\text { eu acho que [a pílula do dia seguinte] } \\
\text { não é um método abortivo / eu } \\
\text { também não acho }\end{array}$ & $\begin{array}{l}\text { é um método contraceptivo } \\
\text { [um método que previne é } \\
\text { contraceptivo, não abortivo] }\end{array}$ & & & $\begin{array}{c}\text { Raciocínio Moral } \\
\text { Deontológico / Regras e } \\
\text { Aplicabilidade - } \\
\text { Conceitos (contracepção } \\
\text { e aborto) }\end{array}$ \\
\hline $\begin{array}{c}\text { R31, } \\
\text { R33c, A32 }\end{array}$ & $\begin{array}{c}\text { se for abortivo vai ter que ter } \\
\text { as mesmas leis }\end{array}$ & & $\begin{array}{c}\text { o status legal da pílula do dia } \\
\text { seguinte deve ser diferente do } \\
\text { do aborto }\end{array}$ & & & $\begin{array}{c}\text { Raciocínio Moral } \\
\text { Deontológico / Regras e } \\
\text { Aplicabilidade }\end{array}$ \\
\hline A34 & & $\begin{array}{l}\text { então [a pílula do dia seguinte] é um } \\
\text { método que previne }\end{array}$ & & & & Moral Intuitiva \\
\hline
\end{tabular}




\begin{tabular}{|c|c|c|c|c|c|}
\hline A20 & ela não usou camisinha & \multirow{2}{*}{$\begin{array}{l}\text { ela tem que tomar sim [a pílula do dia } \\
\text { seguinte] pra caso ela não fique } \\
\text { grávida }\end{array}$} & \multirow{2}{*}{$\begin{array}{l}\text { a gravidez é indesejada e a } \\
\text { pílula evita a gravidez }\end{array}$} & & \multirow{2}{*}{$\begin{array}{l}\text { Raciocínio Moral } \\
\text { Consequencialista/ } \\
\text { Planejamento Familiar }\end{array}$} \\
\hline A20 & a camisinha estourou & & & & \\
\hline $\mathrm{Re}, \mathrm{Ge}$ & $\begin{array}{l}\text { é um método de prevenção / } \\
\text { eu acho um método } \\
\text { contraceptivo }\end{array}$ & \multirow[t]{2}{*}{$\begin{array}{l}\text { a pílula do dia seguinte deveria ser } \\
\text { liberada / acho que pode ser permitido } \\
\text { / no meu país ela seria liberada }\end{array}$} & \multicolumn{2}{|l|}{$\begin{array}{l}\text { métodos de prevenção não } \\
\text { devem ser proibidos }\end{array}$} & $\begin{array}{c}\text { Raciocínio Moral } \\
\text { Deontológico / Regras e } \\
\text { Aplicabilidade - } \\
\text { Conceitos (contracepção } \\
\text { e aborto) }\end{array}$ \\
\hline $\begin{array}{c}\text { R40C, } \\
\text { G38, A39C }\end{array}$ & & & & & Moral Intuitiva \\
\hline A98 & & $\begin{array}{l}\text { se vai abortar é quase a mesma coisa } \\
\text { que você dar pra alguém }\end{array}$ & & & $\begin{array}{l}\text { Moral Intuitiva / Respeito } \\
\text { à Vida - Cuidado Extra- } \\
\text { Familliar }\end{array}$ \\
\hline A96 & & dá pra alguém [a mãe pode dar o filho] & & & $\begin{array}{l}\text { Moral Intuitiva / Respeito } \\
\text { à Vida - Cuidado Extra- } \\
\text { Familliar }\end{array}$ \\
\hline A85 & & é errado abortar & & & $\begin{array}{c}\text { Moral Intuitiva / Respeito } \\
\text { à Vida }\end{array}$ \\
\hline $\begin{array}{l}\text { G44, A45, } \\
\text { R46, } \\
\text { G134, } \\
\text { R135, } \\
\text { G136 }\end{array}$ & & $\begin{array}{l}\text { eu concordo [com a lei brasileira] / o } \\
\text { aborto pode ser legalizado } \\
\text { (...) nos casos em que já é legalizado. }\end{array}$ & & & Moral Intuitiva \\
\hline $\begin{array}{l}\text { G93, G99, } \\
\text { G105 }\end{array}$ & $\begin{array}{l}\text { pode estragar a vida de uma } \\
\text { menina ficar grávida }\end{array}$ & $\begin{array}{l}\text { é melhor legalizar o aborto / devia ser } \\
\text { legalizado }\end{array}$ & $\begin{array}{l}\text { o aborto seria mais } \\
\text { recomendado [uma solução } \\
\text { para não estragar a vida] }\end{array}$ & depende do caso & $\begin{array}{c}\text { Moral Emotiva - } \\
\text { Raciocínio Moral } \\
\text { Consequencialista / } \\
\text { Implicações p/ Vida da } \\
\text { Mãe }\end{array}$ \\
\hline
\end{tabular}




\begin{tabular}{|c|c|c|c|c|c|}
\hline G86 & $\begin{array}{l}\text { os pais podem expulsar a } \\
\text { pessoa de casa }\end{array}$ & $\begin{array}{l}\text { depende do caso [ser errado ou não } \\
\text { abortar] }\end{array}$ & $\begin{array}{l}\text { tem gente que complica toda a } \\
\text { vida }\end{array}$ & & \\
\hline G103 & $\begin{array}{l}\text { você ta matando uma } \\
\text { pessoa...uma vida }\end{array}$ & $\begin{array}{l}\text { eu acho que não deveria [o aborto } \\
\text { não devia ser legalizado] }\end{array}$ & matar é errado & & $\begin{array}{c}\text { Raciocínio Moral } \\
\text { Deontológico / Respeito } \\
\text { à Vida }\end{array}$ \\
\hline $\mathrm{A} 48, \mathrm{Ge}$ & $\begin{array}{l}\text { a mulher não teve } \\
\text { escolha...ela foi tipo forçada, } \\
\text { foi obrigada a fazer tudo, foi } \\
\text { violentada a nano tem culpa / } \\
\text { no estupro ela foi forçada }\end{array}$ & & $\begin{array}{l}\text { ela não queria aquele filho foi } \\
\text { porque ela foi estuprada } \\
\text { /ninguém é obrigado a querer } \\
\text { algo fruto de uma situação que } \\
\text { não pode controlar }\end{array}$ & no caso de & $\begin{array}{c}\text { Moral Emotiva - } \\
\text { Raciocínio Moral } \\
\text { Deontológico / Acidentes } \\
\text { e Não-Responsabilidade }\end{array}$ \\
\hline $\begin{array}{l}\text { A106, } \\
\text { R121, } \\
\text { G122c, } \\
\text { G140, } \\
\text { R141c, } \\
\text { A142c, } \\
\text { A149, } \\
\text { R152, } \\
\text { G153, } \\
\text { A154c }\end{array}$ & & $\begin{array}{c}\text { eu concordo [com a lei brasileira, que } \\
\text { o aborto deve ser permitido no caso de } \\
\text { estupro] / estuprou e ela fica grávida aí } \\
\text { é legalizado abortar / tá bom [o aborto } \\
\text { ser legalizado] se a pessoa for } \\
\text { estuprada }\end{array}$ & & $\begin{array}{l}\text { estuprada / em } \\
\text { caso de } \\
\text { estupramentos / } \\
\text { quando a mãe for } \\
\text { estuprada }\end{array}$ & Moral Intuitiva \\
\hline $\operatorname{Re}$ & $\begin{array}{l}\text { no estupro ela pode não } \\
\text { querer o filho }\end{array}$ & & [ela] não tem culpa & & $\begin{array}{l}\text { Moral Emotiva / } \\
\text { Acidentes e Não- } \\
\text { Responsabilidade }\end{array}$ \\
\hline $\begin{array}{l}\text { R50, R54 } \\
\text { G51c, } \\
\text { A52c }\end{array}$ & $\begin{array}{l}\text { se a mulher morrer o feto vai } \\
\text { morrer, mas se o feto morrer } \\
\text { a mulher não vai morrer }\end{array}$ & $\begin{array}{c}\text { é muito complicado [o aborto deve ser } \\
\text { permitido no caso de risco de vida da } \\
\text { mãe] / concordo [com a lei brasileira, } \\
\text { que permite o aborto no caso de risco } \\
\text { de vida para a mãe] }\end{array}$ & $\begin{array}{l}\text { melhor [morrer] só o feto do } \\
\text { que o feto e a mãe }\end{array}$ & $\begin{array}{l}\text { no caso de risco } \\
\text { de vida da mãe / } \\
\text { no caso de } \\
\text { gravidez de risco }\end{array}$ & $\begin{array}{l}\text { Raciocínio Moral } \\
\text { Consequencialista / } \\
\text { Respeito à Vida }\end{array}$ \\
\hline
\end{tabular}




\begin{tabular}{|c|c|c|c|c|c|c|}
\hline Ge, Re & $\begin{array}{l}\text { é melhor perder o feto que } \\
\text { não está totalmente } \\
\text { desenvolvido do que o feto e } \\
\text { a mãe é melhor perder o } \\
\text { feto do que o feto e a mãe }\end{array}$ & & $\begin{array}{l}\text { é melhor perder apenas uma } \\
\text { vida ao invés de perder duas }\end{array}$ & & & \\
\hline $\begin{array}{l}\text { R121, } \\
\text { G122c, } \\
\text { A142, } \\
\text { R141c, } \\
\text { G140, } \\
\text { G144, } \\
\text { A145, } \\
\text { G148, } \\
\text { A149, } \\
\text { R152, } \\
\text { G1133, } \\
\text { A154c, } \\
\text { Ge, Ae, } \\
\text { Re }\end{array}$ & & $\begin{array}{l}\text { o aborto deve ser permitido no caso de } \\
\text { risco à saúde da mãe }\end{array}$ & & $\begin{array}{l}\text { no caso de risco à } \\
\text { saúde da mãe / } \\
\text { quando...tiver } \\
\text { risco à saúde / } \\
\text { uma gravidez de } \\
\text { risco }\end{array}$ & & $\begin{array}{l}\text { Moral Intuitiva / Evitar } \\
\text { Riscos }\end{array}$ \\
\hline $\begin{array}{l}\text { R100, } \\
\text { R102, } \\
\text { R107 }\end{array}$ & $\begin{array}{c}\text { uma pessoa que sabia das } \\
\text { consequêências o que ia } \\
\text { acontecer se ela...num...é } \\
\text { não usasse preservativo, ela } \\
\text { sabia disso }\end{array}$ & daí ela tem que assumir [o filho] & $\begin{array}{l}\text { conhecimento dos riscos implica } \\
\text { responsabilidade }\end{array}$ & $\begin{array}{l}\text { caso não usasse } \\
\text { o preservativo }\end{array}$ & $\begin{array}{l}\text { é melhor abortar do } \\
\text { que jogar o filho no } \\
\text { lixo, no esgoto, na rua }\end{array}$ & $\begin{array}{c}\text { Raciocínio Moral } \\
\text { Deontológico / Riscos e } \\
\text { Responsabilidade }\end{array}$ \\
\hline $\begin{array}{l}\text { R107*, } \\
\text { A108c, } \\
\text { G109c }\end{array}$ & & $\begin{array}{l}\text { é melhor abortar do que jogar na rua, } \\
\text { jogar no lixo, no esgoto }\end{array}$ & & & & $\begin{array}{l}\text { Moral Intuitiva / Valor } \\
\text { Relativo da Vida - } \\
\text { Cuidado Parental }\end{array}$ \\
\hline $\begin{array}{l}\text { R112, } \\
\text { G113c, } \\
\text { R114, } \\
\text { R119, } \\
\text { G120, } \\
\text { G125 }\end{array}$ & & $\begin{array}{l}\text { [o aborto] devia ser permitido se a } \\
\text { pessoa provar que não tem condiçōes } \\
\text { financeiras de criar o filho / o aborto } \\
\text { deveria ser legalizado por essas } \\
\text { coisas e por causa de condiçōes } \\
\text { financeiras também }\end{array}$ & & $\begin{array}{l}\text { se a pessoa } \\
\text { provarar que não } \\
\text { tem condições } \\
\text { financeiras de } \\
\text { criar o fillho / só } \\
\text { com essas } \\
\text { condiçōes }\end{array}$ & pode doar & $\begin{array}{l}\text { Moral Intuitiva / Ambição } \\
\text { e Segurança Financeira }\end{array}$ \\
\hline
\end{tabular}




\begin{tabular}{|c|c|c|c|c|c|}
\hline G115 & $\begin{array}{l}\text { O filho é caro, precisa de } \\
\text { fralda }\end{array}$ & \multicolumn{3}{|c|}{$\begin{array}{l}\text { um filho só deve ser criado se os } \\
\text { pais tiverem uma situação } \\
\text { financeira relativamente boa }\end{array}$} & $\begin{array}{c}\text { Raciocínio Moral } \\
\text { Consequencialista / } \\
\text { Ambição e Segurança } \\
\text { Financeira }\end{array}$ \\
\hline $\begin{array}{c}\text { R152, } \\
\text { G120, } \\
\text { A154c, } \\
\text { G125, } \\
\text { G129, } \\
\text { G136, } \\
\text { G140, } \\
\text { R141c, } \\
\text { A142c, } \\
\text { G153, Ge, } \\
\text { Re, Ae }\end{array}$ & & $\begin{array}{l}\text { o aborto deveria ser permitido se a } \\
\text { pessoa não tiver condiçõos } \\
\text { psicológicas de dar à luz / deveria } \\
\text { ser...legalizado em circunstâncias } \\
\text { assim...que devia provar que ela não } \\
\text { teria saúde mental / o aborto deveria } \\
\text { ser legalizado por essas coisas e por } \\
\text { causa de condições (...) também...e de } \\
\text { saúde(...)saúde mental / deveria ser } \\
\text { legalizado, (...)só quando tivesse risco } \\
\text { pra saúde é...e quando desse risco à } \\
\text { saúde mental da pessoa... }\end{array}$ & & $\begin{array}{c}\text { se a pessoa não } \\
\text { tiver condições } \\
\text { psicológicas de } \\
\text { dara à luz/risco à } \\
\text { saúde mental / só } \\
\text { com essas } \\
\text { condições / só } \\
\text { quando tivesse } \\
\text { risco pra saúde } \\
\text { é...e quando } \\
\text { desse risco à } \\
\text { saúde mental da } \\
\text { pessoa... / colocar } \\
\text { a saúde mental } \\
\text { da mãe em risco }\end{array}$ & $\begin{array}{l}\text { Moral Intuitiva / Evitar } \\
\text { Riscos }\end{array}$ \\
\hline G185 & ela quer ser médica & ela deveria continuar estudando & $\begin{array}{l}\text { a realização profissional é muito } \\
\text { importante }\end{array}$ & \multirow{2}{*}{$\begin{array}{l}\text { [caso a menina } \\
\text { fique grávida por } \\
\text { acidente] }\end{array}$} & $\begin{array}{l}\text { Raciocínio Moral } \\
\text { Consequencialista / } \\
\text { Ambição e Segurança } \\
\text { Financeira }\end{array}$ \\
\hline $\begin{array}{l}\text { G189, } \\
\text { A190, } \\
\text { R217 }\end{array}$ & & $\begin{array}{l}\text { deixa com a mãe / dá pra mãe dela, } \\
\text { deixa a mãe dela cuidando, tipo } \\
\text { mamadeira, deixa ela amamentar }\end{array}$ & & & $\begin{array}{c}\text { Moral Intuitiva / Cuidado } \\
\text { Parental }\end{array}$ \\
\hline $\begin{array}{l}\text { A201, } \\
\text { R202, } \\
\text { A203, } \\
\text { R204, } \\
\text { R217, } \\
\text { A218 }\end{array}$ & $\begin{array}{l}\text { melhor que ficar sem, já que } \\
\text { é o sonho dela [tornar-se } \\
\text { médica] / porque pelo } \\
\text { menos assim ela ia se } \\
\text { formar e ao mesmo tempo ia } \\
\text { estar cuidando do filho dela, } \\
\text { ou da filha... }\end{array}$ & $\begin{array}{l}\text { ela tinha que se ausentar um pouco do } \\
\text { colégio durante os meses de gestação } \\
\text { (...) e depois ela repete (...) mas } \\
\text { depois ela retomava os estudos / acho } \\
\text { que ela devia parar esse ano por } \\
\text { exemplo...até ter o filho e depois } \\
\text { repetir a série / deveria se ausentar } \\
\text { um ano do colégio e não abortaria e }\end{array}$ & $\begin{array}{l}\text { a realização profissional é tão } \\
\text { importante quanto a maternidade }\end{array}$ & $\begin{array}{l}\text { [caso a menina } \\
\text { fique grávida por } \\
\text { acidente] }\end{array}$ & $\begin{array}{c}\text { Raciocínio Moral } \\
\text { Consequencialista / } \\
\text { Ambição e Segurança } \\
\text { Financeira - Cuidado } \\
\text { Parental }\end{array}$ \\
\hline
\end{tabular}




\begin{tabular}{|c|c|c|c|c|c|c|}
\hline $\begin{array}{l}\mathrm{Ae}, \mathrm{Re} \\
\mathrm{Ge}\end{array}$ & & $\begin{array}{l}\text { até o primeiro ano de vida do filho e } \\
\text { depois ela retomaria os estudos }\end{array}$ & & \multirow{4}{*}{$\begin{array}{l}\text { [caso a menina } \\
\text { fique grávida por } \\
\text { acidente] }\end{array}$} & & \multirow{2}{*}{ Moral Intuitiva } \\
\hline $\begin{array}{c}\mathrm{R} 242, \\
\mathrm{G} 243, \mathrm{Re} \\
\mathrm{Ge}, \mathrm{Ae}\end{array}$ & & $\begin{array}{l}\text { e trabalharia [ela deveria começar a } \\
\text { trabalhar] meio período }\end{array}$ & & & & \\
\hline G246 & $\begin{array}{l}\text { se ele gostar dela e se ela } \\
\text { gostar dele }\end{array}$ & $\begin{array}{l}\text { eu acho que ele [o pai] deveria propor } \\
\text { em casamento }\end{array}$ & $\begin{array}{l}\text { pessoas que se gostam devem } \\
\text { se casar }\end{array}$ & & $\begin{array}{l}\text { mas se não tiver } \\
\text { amor, acho que ele } \\
\text { deveria cuidar do filho } \\
\text { sim, mas não } \\
\text { precisaria casar... }\end{array}$ & $\begin{array}{c}\text { Raciocínio Moral } \\
\text { Deontológico / } \\
\text { Manutenção de Relações }\end{array}$ \\
\hline G246* & se não tiver amor, & $\begin{array}{l}\text { acho que ele deveria cuidar do filho } \\
\text { sim, mas não precisaria casar... }\end{array}$ & $\begin{array}{l}\text { é mais importante cuidar de um } \\
\text { filho do que casar }\end{array}$ & & & $\begin{array}{c}\text { Raciocínio Moral } \\
\text { Deontológico / Cuidado } \\
\text { Parental }\end{array}$ \\
\hline R247 & & ele podia trancar a faculdade & & \multirow{3}{*}{$\begin{array}{l}\text { [caso a menina } \\
\text { fique grávida por } \\
\text { acidente] }\end{array}$} & & $\begin{array}{c}\text { Moral Intuitiva / Cuidado } \\
\text { Parental }\end{array}$ \\
\hline $\begin{array}{l}\mathrm{Re}, \mathrm{Ge} \\
\mathrm{Ae}\end{array}$ & & & & & & $\begin{array}{l}\text { Moral Intuitiva / Ambição } \\
\text { e Segurança Financeira }\end{array}$ \\
\hline R248 & $\begin{array}{l}\text { para eles se casarem é uma } \\
\text { decisão muito assim, porque } \\
\text { depois ele pode chegar e } \\
\text { não gostar mas ainda } \\
\text { continuar criando o filho } \\
\text { sabe. }\end{array}$ & $\begin{array}{c}\text { ele não deveria abandonar os estudos } \\
\text { assim / Ele continuaria na } \\
\text { Universidade }\end{array}$ & $\begin{array}{l}\text { casamento é uma decisão } \\
\text { importante e não definitiva; } \\
\text { estudo e paternidade são mais } \\
\text { importantes }\end{array}$ & & & $\begin{array}{c}\text { Raciocínio Moral } \\
\text { Consequencialista / } \\
\text { Cuidado Parental - } \\
\text { Ambição e Segurança } \\
\text { Financeira }\end{array}$ \\
\hline $\begin{array}{l}\text { G250, } \\
\text { G256, Re, } \\
\text { Ge, } \mathrm{Ae}\end{array}$ & & $\begin{array}{l}\text { ele arranjaria também um trabalho de } \\
\text { meio período também....ele deveria } \\
\text { pegar um emprego de meio período } \\
\text { também...pra ajudar...e fazer o curso } \\
\text { também.../ ele continuaria na } \\
\text { universidade...arrumaria um emprego } \\
\text { de meio período... e ajudaria a criar o } \\
\text { filho... }\end{array}$ & & $\begin{array}{l}\text { [caso a menina } \\
\text { fique grávida por } \\
\text { acidente] }\end{array}$ & & $\begin{array}{c}\text { Moral Intuitiva / Cuidado } \\
\text { Parental }\end{array}$ \\
\hline
\end{tabular}




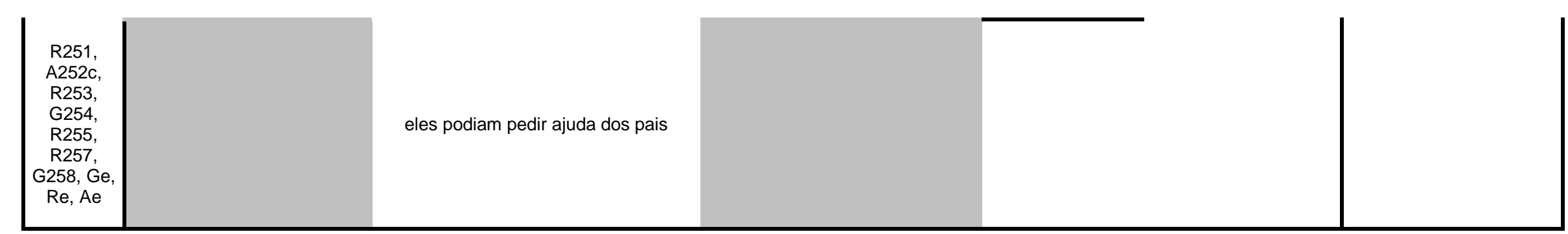


Anexo IV Grupo C

Cinza: partes do argumento que não pertencem àquela categoria

Negrito: a garantia está explícita

"c": o aluno não disse o argumento, mas concordou com ele

* Subargumentos ramificados da refutacão do argumento anterior

\begin{tabular}{|c|c|c|c|c|c|c|}
\hline \multirow{2}{*}{$\begin{array}{c}\text { Aluno e } \\
\text { Enunciado }\end{array}$} & \multicolumn{5}{|c|}{ Argumentos ou Asserções } & \multirow{2}{*}{ Padrão Moral / Valor } \\
\hline & Dado (dado que...) & Conclusão/Asserção & Garantia (já que...) & Qualificador & $\begin{array}{c}\text { Refutador (a menos } \\
\text { que...) }\end{array}$ & \\
\hline $\begin{array}{c}\text { D2, P4, } \\
\text { D49, } \\
\text { W50c, } \\
\text { P51c, } \\
\text { C52c, } \\
\text { L53c, L61, } \\
\text { L154, } \\
\text { W155c, } \\
\text { Ce }\end{array}$ & . & \multirow{2}{*}{$\begin{array}{l}\text { o aborto deve ser permitido quando a } \\
\text { mãe tem risco de vida / tem que } \\
\text { abortar / é melhor a mãe viver do que } \\
\text { o filho morrer, o filho ficar dentro da } \\
\text { barriga da mãe / deveria abortar / o } \\
\text { grupo concorda com o aborto se } \\
\text { houver risco de vida }\end{array}$} & . & \multirow{2}{*}{$\begin{array}{l}\text { só quando a mãe tem } \\
\text { risco de vida / só no } \\
\text { risco da mãe poder } \\
\text { morrer e ela não } \\
\text { quiser ter o filho } \\
\text { mesmo / se a mãe } \\
\text { puder morrer / se } \\
\text { houver risco de vida }\end{array}$} & & $\begin{array}{l}\text { Moral Intuitiva / Valo } \\
\text { Relativo da Vida }\end{array}$ \\
\hline $\begin{array}{l}\text { P149, } \\
\text { D60, } \\
\text { D148 }\end{array}$ & $\begin{array}{c}\text { o bebê ainda não teve } \\
\text { nenhuma lembrança, } \\
\text { nenhuma família, ainda não } \\
\text { tem sentimentos / o bebê } \\
\text { ainda não viveu / a mãe teve } \\
\text { mais vida do que o filho...eu } \\
\text { acho que ela tem família, ela } \\
\text { tem mais sentimentos tem } \\
\text { mais coisas... }\end{array}$ & & $\begin{array}{l}\text { as experiências vividas e os } \\
\text { sentimentos conferem maior } \\
\text { valor relativo a uma vida }\end{array}$ & & & $\begin{array}{l}\text { Raciocínio Moral } \\
\text { Deontológico/Valor } \\
\text { Relativo da Vida }\end{array}$ \\
\hline
\end{tabular}




\begin{tabular}{|c|c|c|c|c|c|c|}
\hline $\begin{array}{l}\text { Ce, Wec, } \\
\text { Pec, Dec, } \\
\text { Lec }\end{array}$ & $\begin{array}{l}\text { tem que se escolher entre a } \\
\text { mãe e o filho }\end{array}$ & & $\begin{array}{l}\text { obrigatoriedade de escolher leva } \\
\text { a prevalecer a escolha da } \\
\text { mulher }\end{array}$ & & & $\begin{array}{l}\text { Raciocínio Moral } \\
\text { Deontológico / Valor } \\
\text { Relativo da Vida }\end{array}$ \\
\hline W8 & \multirow{2}{*}{$\begin{array}{l}\text { a criança pode viver uma } \\
\text { vida normal no orfanato / há } \\
\text { orfanatos onde se pode } \\
\text { deixar a criança lá / tudo } \\
\text { bem botar no orfanato }\end{array}$} & $\begin{array}{l}\text { [o aborto] só deve ser permitido em } \\
\text { caso de risco de vida da mãe }\end{array}$ & $\begin{array}{c}\text { por que tirar a vida de } \\
\text { alguém? [não há necessidade } \\
\text { de matar] }\end{array}$ & $\begin{array}{l}\text { só quando a mãe tem } \\
\text { risco de vida }\end{array}$ & & $\begin{array}{c}\text { Raciocínio Moral } \\
\text { Deontológico / Respeito } \\
\text { à Vida }\end{array}$ \\
\hline D148 & & \multirow{2}{*}{$\begin{array}{c}\text { o aborto não deve ser permitido } \\
\text { quando a mulher é estuprada / } \\
\text { nenhum dos dois sente emoção pelo } \\
\text { filho e aí acha que...o filho vai ser uma } \\
\text { desgraça...aí eu não acho que seja } \\
\text { uma desgraça... }\end{array}$} & $\begin{array}{c}\text { tem várias instituições que } \\
\text { ajudam [se a mãe não quiser o } \\
\text { filho] }\end{array}$ & $\begin{array}{l}\text { quando a mulher é } \\
\text { estuprada }\end{array}$ & & $\begin{array}{l}\text { Raciocínio Moral } \\
\text { Consequencialista / } \\
\text { Cuidado Extra-familiar }\end{array}$ \\
\hline $\begin{array}{l}\text { L147, } \\
\text { D157c, } \\
\text { W158c, } \\
\text { D148, Ce }\end{array}$ & $\begin{array}{c}\text { o amor vai crescendo com o } \\
\text { tempo / o bebê vai ser } \\
\text { amado e ter uma vida com o } \\
\text { tempo }\end{array}$ & & $\begin{array}{c}\text { a mulher não precisa querer o } \\
\text { filho para tê-lo / dá pra amar } \\
\text { qualquer pessoa }\end{array}$ & & $\begin{array}{l}\text { há muito caso de } \\
\text { emoção }\end{array}$ & $\begin{array}{c}\text { Moral Emotiva / } \\
\text { Manutenção de Relações }\end{array}$ \\
\hline C56, P57 & $\begin{array}{c}\text { se por exemplo ocorrer algo, } \\
\text { é... risco de vida }\end{array}$ & $\begin{array}{c}\text { pegar o embrião e colocar em outra } \\
\text { mãe... }\end{array}$ & $\begin{array}{c}\text { como hoje existe já né é a mãe } \\
\text { de aluguel né... para não ter } \\
\text { esse problema }\end{array}$ & & $\begin{array}{l}\text { o feto já está grande } \\
\text { demais pra fazer } \\
\text { essa... mãe de } \\
\text { aluguel... }\end{array}$ & $\begin{array}{l}\text { Raciocínio Moral } \\
\text { Consequencialista / } \\
\text { Conceitos (técnica } \\
\text { médica e mãe de } \\
\text { aluguel) - Respeito à } \\
\text { Vida }\end{array}$ \\
\hline $\begin{array}{l}\text { P138, } \\
\text { D139 }\end{array}$ & estupro & $\begin{array}{c}\text { poderia ter...ela poderia deixar numas } \\
\text { instituições...orfanatos...essas } \\
\text { coisas.../ devia deixar em algumas } \\
\text { instituições }\end{array}$ & ela não quer ter o filho do cara & & $\begin{array}{l}\text { [se a mulher for } \\
\text { estuprada, deveria] } \\
\text { talvez até criar...assim } \\
\text { até criar você } \\
\text { mesmo... }\end{array}$ & $\begin{array}{l}\text { Moral Emotiva / Cuidado } \\
\text { Extra-familiar - } \\
\text { Raciocínio Moral } \\
\text { Deontológico / Direitos } \\
\text { da Mulher }\end{array}$ \\
\hline D139* & & $\begin{array}{l}\text { [se a mulher for estuprada, deveria] } \\
\text { talvez até criar...assim até criar você } \\
\text { mesmo... }\end{array}$ & & & & $\begin{array}{c}\text { Moral Intuitiva / Cuidado } \\
\text { Parental }\end{array}$ \\
\hline
\end{tabular}




\begin{tabular}{|c|c|c|c|c|c|}
\hline $\begin{array}{l}\text { P4, C40, } \\
\text { W34, D78, } \\
\quad \text { Ce }\end{array}$ & & $\begin{array}{c}\text { a mãe pode colocar a criança no } \\
\text { orfanato caso não queira ter o filho / } \\
\text { pra qualquer coisa tem essas } \\
\text { instituições do } \\
\text { governo...orfanatos...essas coisas... / } \\
\text { deveria arrumar alguém para cuidar da } \\
\text { criança por enquanto.../ colocar numa } \\
\text { instituição por enquanto até eles } \\
\text { ficarem prontos para ter um filho / ela } \\
\text { bota o filho no orfanato e ela visita } \\
\text { todo dia pro filho ser dela, ela } \\
\text { conversa... }\end{array}$ & & $\begin{array}{l}1 \text { caso não queira ter } \\
\text { o filho } \\
2 \text { caso não consiga } \\
\text { cuidar }\end{array}$ & $\begin{array}{l}\text { Moral Intuitiva / Cuidado } \\
\text { Extra-Familiar }\end{array}$ \\
\hline C125 & $\begin{array}{l}\text { Porque é a mesma coisa } \\
\text { que fosse um aborto }\end{array}$ & $\begin{array}{c}\text { eu consideraria que essa pílula não } \\
\text { era permitida... }\end{array}$ & $\begin{array}{l}\text { as mesmas regras devem ser } \\
\text { aplicadas a casos semelhantes }\end{array}$ & & $\begin{array}{l}\text { Raciocínio Moral } \\
\text { Deontológico / Regras e } \\
\text { Aplicabilidade }\end{array}$ \\
\hline L118 & $\begin{array}{l}\text { se os pais não tivessem } \\
\text { pensado em se prevenir }\end{array}$ & $\begin{array}{l}\text { a pílula do dia seguinte é um método } \\
\text { abortivo }\end{array}$ & $\begin{array}{l}\text { o status da pílula do dia seguinte } \\
\text { depende da possibilidade de } \\
\text { prevenção dos pais }\end{array}$ & & $\begin{array}{l}\text { Raciocínio Moral } \\
\text { Deontolótgico / Regras e } \\
\text { Aplicabilidade - Riscos e } \\
\text { Responsabilidade }\end{array}$ \\
\hline W114 & você tá impedindo que um & $\begin{array}{l}\text { a pílula do dia seguinte é um método } \\
\text { abortivo }\end{array}$ & $\begin{array}{l}\text { impedir o desenvolvimento é o } \\
\text { mesmo que abortar }\end{array}$ & $\begin{array}{c}\text { se o espermatozóide } \\
\text { não tiver encontrado o } \\
\text { óvulo }\end{array}$ & $\begin{array}{c}\text { Raciocínio Moral } \\
\text { Deontológico / Respeito } \\
\text { à Vida - Conceitos } \\
\text { (desenvolvimento e } \\
\text { aborto) }\end{array}$ \\
\hline $\mathrm{P} 134$ & desenvolva & $\begin{array}{l}\text { isso daí [pílula do dia seguinte] não é } \\
\text { um aborto / a pílula do dia seguinte } \\
\text { não é um método abortivo / [a pílula do } \\
\text { dia seguinte] não chega a ser um }\end{array}$ & $\begin{array}{l}\text { você não tá matando um ser } \\
\text { [na pílula do dia seguinte] }\end{array}$ & & $\begin{array}{l}\text { Raciocínio Moral } \\
\text { Deontológico / Respeito } \\
\text { à Vida, Limites da Vida - } \\
\text { Conceitos (ação da } \\
\text { pílula) }\end{array}$ \\
\hline L118 & $\begin{array}{c}\text { se os pais tivessem pensado } \\
\text { em se prevenir }\end{array}$ & $\begin{array}{l}\text { seja um método abortivo / não chega a } \\
\text { ser aborto / não acho que é uma } \\
\text { técnica que deve ser ilegal... }\end{array}$ & $\begin{array}{l}\text { o status da pílula do dia seguinte } \\
\text { depende da possibilidade de } \\
\text { prevenção dos pais }\end{array}$ & & $\begin{array}{c}\text { Raciocínio Moral } \\
\text { Deontolótgico / Acidentes } \\
\text { e Não-Responsabilidade } \\
\text { - Regras e Aplicabilidade }\end{array}$ \\
\hline
\end{tabular}




\begin{tabular}{|c|c|c|c|c|c|}
\hline $\begin{array}{l}\text { L120, } \\
\text { P121c, } \\
\text { D122C }\end{array}$ & não chega a ser vida ainda & & $\begin{array}{l}\text { um método abortivo mata uma } \\
\text { vida }\end{array}$ & & $\begin{array}{c}\text { Raciocínio Moral } \\
\text { Deontológico / Regras e } \\
\text { Aplicabilidade - Limites } \\
\text { da Vida }\end{array}$ \\
\hline $\begin{array}{l}\text { L126, } \\
\text { P127c, } \\
\text { W128c }\end{array}$ & \multirow{2}{*}{$\begin{array}{l}\text { muitas vezes a camisinha } \\
\text { pode falhar }\end{array}$} & \multirow{4}{*}{$\begin{array}{c}\text { tem que tomar a pílula do dia seguinte, } \\
\text { tem que ser liberado / tinha que ser } \\
\text { permitida a pílula do dia seguinte... / } \\
\text { no meu país seria permitido / liberado / } \\
\text { deveria ser liberada }\end{array}$} & $\begin{array}{l}\text { o cara tentou se prevenir a } \\
\text { não chegar a vida ainda }\end{array}$ & & $\begin{array}{l}\text { Moral Emotiva - } \\
\text { Raciocínio Moral } \\
\text { Deontológico / Acidentes } \\
\text { e Não-Responsabilidade }\end{array}$ \\
\hline $\begin{array}{l}\text { L129, } \\
\text { D131C, } \\
\text { P134c }\end{array}$ & & & \multicolumn{2}{|l|}{$\begin{array}{l}\text { é como um acidente, não tinha } \\
\text { como evitar }\end{array}$} & $\begin{array}{l}\text { Moral Emotiva - } \\
\text { Raciocínio Moral } \\
\text { Deontológico / Acidentes } \\
\text { e Não-Responsabilidade }\end{array}$ \\
\hline $\begin{array}{l}\text { D122, } \\
\text { C141, } \\
\text { P142 }\end{array}$ & & & & $\begin{array}{c}\text { se já passou as } 72 \\
\text { horas... }\end{array}$ & $\begin{array}{c}\text { Moral Intuitiva / Regras e } \\
\text { Aplicabilidade }\end{array}$ \\
\hline $\mathrm{Ce}$ & não é técnica abortiva & & \multicolumn{2}{|l|}{$\begin{array}{c}\text { técnicas que não são abortivas } \\
\text { devem ser liberadas }\end{array}$} & \multirow[b]{2}{*}{$\begin{array}{c}\text { Raciocínio Moral } \\
\text { Deontológico / Regras e } \\
\text { Aplicabilidade }\end{array}$} \\
\hline $\begin{array}{l}\text { P115, } \\
\text { W116 }\end{array}$ & $\begin{array}{l}\text { Eu não acho que seja um } \\
\text { método abortivo }\end{array}$ & & $\begin{array}{l}\text { é um método que você só } \\
\text { pode usar em últimas causas }\end{array}$ & $\begin{array}{c}\text { se o espermatozóide } \\
\text { não tiver encontrado o } \\
\text { óvulo... }\end{array}$ & \\
\hline L118 & $\begin{array}{c}\text { se os pais tivessem pensado } \\
\text { em se prevenir }\end{array}$ & no meu país seria liberado & \multicolumn{2}{|l|}{$\begin{array}{l}\text { o status da pílula do dia seguinte } \\
\text { depende da possibilidade de } \\
\text { prevenção dos pais }\end{array}$} & $\begin{array}{c}\text { Raciocínio Moral } \\
\text { Deontolótgico / Acidentes } \\
\text { e Não-Responsabilidade }\end{array}$ \\
\hline $\mathrm{P} 145^{*}$ & se depois das 72 horas & $\begin{array}{l}\text { daí eu acho que ninguém tem direito } \\
\text { de fazer isso...[abortar] }\end{array}$ & $\begin{array}{l}\text { ele [o embrião] já se } \\
\text { desenvolveu }\end{array}$ & & $\begin{array}{c}\text { Raciocínio Moral } \\
\text { Deontológico / Respeito } \\
\text { à Vida }\end{array}$ \\
\hline W128 & se a camisinha estourou & eles não vão ter culpa & foi um acidente & & $\begin{array}{c}\text { Moral Emotiva - } \\
\text { Raciocínio Moral } \\
\text { Deontológico / Acidentes } \\
\text { e Não-Responsabilidade }\end{array}$ \\
\hline
\end{tabular}




\begin{tabular}{|c|c|c|c|c|c|}
\hline L31 & $\begin{array}{l}\text { num puder cuidar do filho, } \\
\text { não tem dinheiro, não tem } \\
\text { condições de vida próprias } \\
\text { pra ter o filho }\end{array}$ & $\begin{array}{l}\text { deixa o filho num orfanato...numa } \\
\text { instituição do governo, deixa pra outra } \\
\text { pessoa cuidar }\end{array}$ & $\begin{array}{l}\text { ajuda sempre tem em qualquer } \\
\text { lugar [o filho não precisa ser } \\
\text { cuidado pela mãe] }\end{array}$ & & $\begin{array}{c}\text { Raciocínio Moral } \\
\text { Consequencialista / } \\
\text { Cuidado Extra-familiar - } \\
\text { Ambição e Segurança } \\
\text { Financeira }\end{array}$ \\
\hline C144 & $\begin{array}{c}\text { nós não somos ninguém } \\
\text { para poder tirar a vida de } \\
\text { outra pessoa/ninguém tem o } \\
\text { direito de tirar a vida de um } \\
\text { humano }\end{array}$ & $\begin{array}{l}\text { a criança tem direito de viver / tem que } \\
\text { deixar ele nascer }\end{array}$ & $\begin{array}{c}\text { matar é errado / o ser na barriga } \\
\text { da mãe já é uma pessoa/uma } \\
\text { criança }\end{array}$ & & $\begin{array}{c}\text { Raciocínio Moral } \\
\text { Deontológico / Respeito } \\
\text { à Vida }\end{array}$ \\
\hline P140 & & $\begin{array}{l}\text { toda mãe...independente do pai....ama } \\
\text { o filho de uma maneira incondicional... }\end{array}$ & & & $\begin{array}{c}\text { Moral Intuitiva / Cuidado } \\
\text { Parental }\end{array}$ \\
\hline P6 & & $\begin{array}{l}\text { ninguém tem o direito de tirar a vida } \\
\text { dos outros }\end{array}$ & & & $\begin{array}{c}\text { Moral Intuitiva / Respeito } \\
\text { à Vida }\end{array}$ \\
\hline D25 & $\begin{array}{l}\text { os pais do namorado dela e } \\
\text { os pais dela deviam } \\
\text { ajudar...trabalhar... }\end{array}$ & \multirow{2}{*}{$\begin{array}{c}\text { ela devia pedir ajuda para os pais e } \\
\text { para os pais do cara que fez isso com } \\
\text { ela. }\end{array}$} & $\begin{array}{c}\text { é como se fosse um meio filho } \\
\text { de cada família... }\end{array}$ & \multirow{6}{*}{$\begin{array}{l}\text { [caso a menina fique } \\
\text { grávida por acidente] }\end{array}$} & \multirow{2}{*}{$\begin{array}{c}\text { Moral Emotiva / Cuidado } \\
\text { Parental }\end{array}$} \\
\hline P26 & $\begin{array}{l}\text { porque ela não fez o filho } \\
\text { sozinha }\end{array}$ & & $\begin{array}{c}\text { a participação do homem no ato } \\
\text { sexual exige a participação de } \\
\text { seus pais no processo de } \\
\text { criação }\end{array}$ & & \\
\hline $\mathrm{Ce}$ & & & & & Moral Intuitiva \\
\hline $\mathrm{C} 27$ & $\begin{array}{c}\text { ela pode estar indo pra } \\
\text { escola...ninguém vai ficar } \\
\text { assim...tirando da cara dela. }\end{array}$ & $\begin{array}{c}\text { ela não precisa parar de estudar / } \\
\text { continuar os estudos }\end{array}$ & $\begin{array}{l}\text { o único empecilho para ela } \\
\text { continuar estudando grávida } \\
\text { seria a coerção social }\end{array}$ & & $\begin{array}{c}\text { Raciocínio Moral } \\
\text { Consequencialista / } \\
\text { Implicações para a Vida } \\
\text { da Mãe }\end{array}$ \\
\hline L29 & & $\begin{array}{l}\text { devia procurar todo tipo de ajuda } \\
\text { possível...não tomar uma decisão } \\
\text { rápida (...)primeiro procurar o máximo } \\
\text { de ajuda possível...opinião formada e } \\
\text { aí decidir o que vai fazer da vida... }\end{array}$ & & & Moral Intuitiva \\
\hline W36 & & $\begin{array}{l}\text { tentar arrumar um trabalho e estudar } \\
\text { ao mesmo tempo }\end{array}$ & & & $\begin{array}{l}\text { Moral Intuitiva / Ambição } \\
\text { e Segurança Financeira }\end{array}$ \\
\hline
\end{tabular}




\begin{tabular}{|c|c|c|c|c|}
\hline $\begin{array}{l}\text { D42, D44, } \\
\text { L79, Ce }\end{array}$ & & $\begin{array}{c}\text { pedir ajuda pra o máximo de pessoas / } \\
\text { pedir a máxima ajuda }\end{array}$ & & Moral Intuitiva \\
\hline $\begin{array}{l}\text { D32, D42, } \\
\text { W45 }\end{array}$ & $\begin{array}{l}\text { quando a mãe não tem } \\
\text { dinheiro / e quando não der } \\
\text { [quando não tiverem } \\
\text { condições de criar o filho] }\end{array}$ & $\begin{array}{c}\text { ela [a mãe] devia botar no orfanato e } \\
\text { visitar todo dia o filho pro filho ser dela } \\
\text { e depois quando ela arranjar dinheiro, } \\
\text { ficar mais crescida, acabar os estudos, } \\
\text { ela pegar o filho e ficar com o filho } \\
\text { para sempre / eles botarem no } \\
\text { orfanato e visitar todo dia / Deixar a } \\
\text { criança em algum lugar até mesmo } \\
\text { como o D. falou num orfanato (...) até } \\
\text { que ele [o pai] termine os estudos e } \\
\text { possa arrumar emprego pra cuidar da } \\
\text { criança... }\end{array}$ & $\begin{array}{c}\text { é preciso ter estabilidade } \\
\text { financeira para criar uma } \\
\text { criança, que não precisa crescer } \\
\text { na presença dos pais }\end{array}$ & $\begin{array}{l}\text { Moral Emotiva / Ambição } \\
\text { e Segurança Financeira - } \\
\text { Cuidado Extra-familiar - } \\
\text { Cuidado Parental }\end{array}$ \\
\hline L43 & $\begin{array}{c}\text { não pode tentar estragar a } \\
\text { vida assim, não por um } \\
\text { acidente... }\end{array}$ & $\begin{array}{l}\text { ele [o pai] devia tentar fazer o máximo } \\
\text { possível para ajudar economicamente, } \\
\text { financeiramente e paternalmente } \\
\text { também, mas ao mesmo tempo } \\
\text { continuar com a vida, tentar continuar } \\
\text { com a vida o máximo possível }\end{array}$ & $\begin{array}{c}\text { é importante conciliar a } \\
\text { paternidade com a carreira e os } \\
\text { estudos }\end{array}$ & $\begin{array}{l}\text { Raciocínio Moral } \\
\text { Consequencialista / } \\
\text { Cuidado Parental - } \\
\text { Ambição e Segurança } \\
\text { Financeira }\end{array}$ \\
\hline $\mathrm{Ce}$ & & arranjar um emprego melhor & & \multirow{2}{*}{$\begin{array}{l}\text { Moral Intuitiva / Ambição } \\
\text { e Segurança Financeira }\end{array}$} \\
\hline $\mathrm{Ce}$ & & \multirow{2}{*}{$\begin{array}{l}\text { ele não devia abandonar os estudos } \\
\text { (...) nunca abandonar os estudos / } \\
\text { continuar estudando / nunca largar os } \\
\text { estudos / ela não larga os estudos / } \\
\text { ele deveria continuar os estudos }\end{array}$} & & \\
\hline D44, W45 & $\begin{array}{l}\text { porque os estudos são a } \\
\text { maior coisa que podem dar } \\
\text { ao seu filho a felicidade... }\end{array}$ & & $\begin{array}{l}\text { o pai deve garantir, através de } \\
\text { seus estudos, a felicidade do } \\
\text { filho }\end{array}$ & $\begin{array}{c}\text { Raciocínio Moral } \\
\text { Consequencialista / } \\
\text { Ambição e Segurança } \\
\text { Financeira }\end{array}$ \\
\hline
\end{tabular}




\begin{tabular}{|c|c|c|c|}
\hline $\begin{array}{l}\text { C46, D78, } \\
\text { P81, D82, } \\
\text { P83c, C84 }\end{array}$ & $\begin{array}{l}\text { porque se ele continuar os } \\
\text { estudos vai ser mais rápido } \\
\text { ainda de ele conseguir um } \\
\text { bom emprego e conseguir } \\
\text { dinheiro suficiente pra } \\
\text { conseguir cuidar do filho.../ } \\
\text { pra ela arranjarar uma } \\
\text { profissão bem melhor e ter } \\
\text { dinheiro pra botar o filho em } \\
\text { casa....o futuro../ para } \\
\text { arranjar um trabalho melhor } \\
\text { pra ter o fillo em casa no } \\
\text { futuro.../p ra ter mais } \\
\text { dinheiro suficiente...pra } \\
\text { poder criar o filho direito... }\end{array}$ & $\begin{array}{l}\text { é importante ter boas condições } \\
\text { financeiras para criar um filho } \\
\text { direito }\end{array}$ & $\begin{array}{c}\text { Raciocínio Moral } \\
\text { Consequencialista / } \\
\text { Ambição e Segurançaa } \\
\text { Financeira }\end{array}$ \\
\hline
\end{tabular}


Anexo IV Grupo D

Cinza: partes do argumento que não pertencem àquela categoria

Negrito: a garantia está explícita

"c": o aluno não disse o argumento, mas concordou com ele

* Subargumentos ramificados da refutacão do argumento anterior

\begin{tabular}{|c|c|c|c|c|c|c|}
\hline \multirow{2}{*}{$\begin{array}{l}\text { Aluno e } \\
\text { Enunciado }\end{array}$} & \multicolumn{5}{|c|}{ Argumentos ou Asserções } & \multirow[b]{2}{*}{ Padrão Moral / Valor } \\
\hline & Dado (dado que...) & Conclusão/Asserção & Garantia (já que...) & Qualificador & $\begin{array}{c}\text { Refutador (a menos } \\
\text { que...) }\end{array}$ & \\
\hline \multirow{3}{*}{ L5 } & $\begin{array}{l}\text { se não fosse proibido seria } \\
\text { muito mais higiênico }\end{array}$ & \multirow{3}{*}{ [O aborto deveria ser permitido] } & \multirow{3}{*}{ o aborto não vai parar } & & & \multirow{3}{*}{$\begin{array}{l}\text { Raciocínio Moral } \\
\text { Consequencialista / } \\
\text { Ordem Social }\end{array}$} \\
\hline & $\begin{array}{l}\text { ia sobreviver muito mais } \\
\text { pessoas [muito mais } \\
\text { mulheres sobreviveriam] }\end{array}$ & & & & & \\
\hline & $\begin{array}{l}\text { não ia existir tantas coisas } \\
\text { clandestinas }\end{array}$ & & & & & \\
\hline $\mathrm{Ke}, \mathrm{L} 8$ & & \multirow[t]{3}{*}{$\begin{array}{l}\text { O aborto seria proibido/não seria } \\
\text { permitido / o aborto é proibido }\end{array}$} & & & $\begin{array}{c}\text { exceto em casos } \\
\text { extremos: estupro e } \\
\text { risco de morte / a não } \\
\text { ser duas questões, é... } \\
\text { o estupro ou sei lá..ta } \\
\text { em risco de vida ou } \\
\text { morte a mãe da } \\
\text { criança }\end{array}$ & $\begin{array}{c}\text { Moral Intuitiva / Respeito } \\
\text { à Vida }\end{array}$ \\
\hline $\mathrm{Ae}$ & & & & & \multirow{2}{*}{$\begin{array}{c}\text { somente em um caso } \\
\text { seria permitido: risco } \\
\text { de vida da mãe / } \\
\text { tirando a quando a } \\
\text { mãe tem risco de } \\
\text { morrer }\end{array}$} & \\
\hline $\mathrm{Ce}$ & $\begin{array}{c}\text { é a mesma coisa que matar } \\
\text { uma vida }\end{array}$ & & $\begin{array}{c}\text { [o aborto] é a morte de um } \\
\text { embrião }\end{array}$ & & & $\begin{array}{l}\text { Raciocínio Moral } \\
\text { Deontológico / Respeito } \\
\text { à Vida }\end{array}$ \\
\hline $\mathrm{C} 4$ & $\begin{array}{l}\text { porque mesmo assim eu } \\
\text { assumiria meu filho }\end{array}$ & $\begin{array}{l}\text { em caso de estupro a mulher não deve } \\
\text { abortar / eu assumiria meu filho / em } \\
\text { caso de estupro não [abortaria] (...) eu }\end{array}$ & $\begin{array}{l}\text { se eu posso assumir o filho, as } \\
\text { outras mulheres também podem }\end{array}$ & & & $\begin{array}{c}\text { Moral Emotiva / Cuidado } \\
\text { Parental }\end{array}$ \\
\hline
\end{tabular}




\begin{tabular}{|c|c|c|c|c|c|c|}
\hline $\begin{array}{l}\mathrm{C} 12, \mathrm{C} 14, \\
\mathrm{C} 24, \mathrm{C} 26 \\
\text { C34, } \\
\mathrm{C} 173, \mathrm{Ce}\end{array}$ & $\begin{array}{l}\text { é filho da mulher / é meu } \\
\text { filho / é um filho teu também } \\
\text { / mesmo assim é o seu fiho, } \\
\text { você vai matar o seu filho? / } \\
\text { filho do cara que te estuprou } \\
\text { e seu filho também / ele } \\
\text { também é fruto de mim / } \\
\text { mesmo sendo fruto de uma } \\
\text { desgraça seria meu filho }\end{array}$ & $\begin{array}{l}\text { não abortaria.../ você não tem que } \\
\text { abortar ele.../ no caso do estupro eu } \\
\text { assumiria meu filho }\end{array}$ & $\begin{array}{l}\text { a maternidade é um valor maior } \\
\text { que outros interesses da mulher }\end{array}$ & se fosse meu filho & $\begin{array}{c}\text { mesmo sendo fruto de } \\
\text { uma desgraça }\end{array}$ & $\begin{array}{l}\text { Moral Emotiva - } \\
\text { Raciocínio Moral } \\
\text { Deontológico / Cuidado } \\
\text { Parental }\end{array}$ \\
\hline C171 & $\begin{array}{l}\text { a partir daquele momento } \\
\text { aquilo é uma vida }\end{array}$ & \multirow{3}{*}{$\begin{array}{c}\text { em caso de estupro a mulher não deve } \\
\text { abortar / eu assumiria meu filho / em } \\
\text { caso de estupro não [abortaria] (...) eu } \\
\text { não abortaria.../ você não tem que } \\
\text { abortar ele.../ no caso do estupro eu } \\
\text { assumiria meu filho }\end{array}$} & $\begin{array}{l}\text { mesmo você não querendo é } \\
\text { um filho seu... }\end{array}$ & & & \multirow[t]{2}{*}{$\begin{array}{c}\text { Raciocí́íio Moral } \\
\text { Deontológico - Moral } \\
\text { Emotiva / Cuidado } \\
\text { Parental - Respeito à } \\
\text { Vida }\end{array}$} \\
\hline C14 & $\begin{array}{l}\text { abortar é matar uma vida / } \\
\text { você vai matar o seu filho? }\end{array}$ & & matar é errado & & & \\
\hline $\begin{array}{l}\mathrm{C} 12, \mathrm{C} 24 \\
\mathrm{Ce}\end{array}$ & $\begin{array}{c}\text { vai ter seu gens lá tem seu } \\
\text { sangue lá tem seu dna lá } \\
\text { tem seus óvulos lá / tem seu } \\
\text { óvulo lá / meu sangue, meu } \\
\text { DNA e tudo mais }\end{array}$ & & $\begin{array}{l}\text { a participação da mulher na } \\
\text { constituição biológica do filho } \\
\text { torna-a responsável por ele }\end{array}$ & & $\begin{array}{c}\text { mesmo sendo fruto de } \\
\text { uma desgraça }\end{array}$ & $\begin{array}{c}\text { Raciocííio Moral } \\
\text { Deontológico / Cuidado } \\
\text { Parental - Conceitos } \\
\text { (gene, dna, sangue e } \\
\text { óvulo) }\end{array}$ \\
\hline C6 & se você não criar & $\begin{array}{l}\text { você pode dar pro orfanato, pode por } \\
\text { na creche }\end{array}$ & $\begin{array}{l}\text { do mesmo jeito você transou } \\
\text { com o seu namorado você já } \\
\text { tem uma vida livre, você já tem } \\
\text { um filho, vai estar se } \\
\text { formando um embrião, é uma } \\
\text { vida, é matar alguém, a mesma } \\
\text { coisa. }\end{array}$ & & & $\begin{array}{l}\text { Raciocínio Moral } \\
\text { Deontológico / Respeito } \\
\text { à Vida - Livre-Arbittio e } \\
\text { Responsabilidade }\end{array}$ \\
\hline C6, С38 & $\begin{array}{l}\text { você fez / se você transou } \\
\text { com } 10\end{array}$ & $\begin{array}{l}\text { agora você assume / agora você vai } \\
\text { assumir os seus } 10 \text { filhos }\end{array}$ & $\begin{array}{l}\text { não importa, porque, você que } \\
\text { compre uma camisinha você } \\
\text { que pegue, que mendigue na } \\
\text { rua e compre uma, porque tem } \\
\text { muitos meios de prevenir... }\end{array}$ & & & $\begin{array}{l}\text { Raciocínio Moral } \\
\text { Deontológico / Riscos e } \\
\text { Responsabilidade }\end{array}$ \\
\hline
\end{tabular}




\begin{tabular}{|c|c|c|c|c|c|}
\hline L35 & $\begin{array}{l}\text { ainda é um embrião de } \\
\text { nada...nem um } \\
\text { embrião...nem se formou... }\end{array}$ & não é um filho & & $\begin{array}{l}\text { se você abortar } \\
24 \text { horas depois }\end{array}$ & $\begin{array}{c}\text { Raciocínio Moral } \\
\text { Deontológico / Limites da } \\
\text { Vida }\end{array}$ \\
\hline $\begin{array}{l}\mathrm{A} 2, \mathrm{Be} \\
\mathrm{Ke}^{*}\end{array}$ & & \multirow{2}{*}{$\begin{array}{l}\text { em caso de estupro a mullher deve } \\
\text { abortar / estupro / em caso de estupro } \\
\text { / uma pessoa que foi estuprada ela } \\
\text { não vai ter que carregar o filho do cara } \\
\text { / ela pode abortar }\end{array}$} & & & $\begin{array}{l}\text { Moral Intuitiva / } \\
\text { Acidentes e Não- } \\
\text { Responsabilidade }\end{array}$ \\
\hline $\begin{array}{l}\text { A172, } \\
\text { L178c }\end{array}$ & $\begin{array}{l}\text { como você vai explicar pro } \\
\text { seu filho assim, ah filhinho } \\
\text { você nasceu de um estupro } \\
\text { do papai! }\end{array}$ & & $\begin{array}{l}\text { não é desejável que o filho saiba } \\
\text { que o pai era um estuprador / ou } \\
\text { que o filho seja fruto de estupro }\end{array}$ & \multirow[t]{2}{*}{$\begin{array}{l}\text { em caso de } \\
\text { estupro }\end{array}$} & $\begin{array}{c}\text { Raciocínio Moral } \\
\text { Consequencialista / } \\
\text { Cuidado Parental - Moral } \\
\text { Emotiva / Implicações } \\
\text { para Vida da Mãe }\end{array}$ \\
\hline L170 & $\begin{array}{l}\text { coitada da menina, ela é } \\
\text { estuprada...ela não precisa } \\
\text { carregar o filho... }\end{array}$ & \multirow{3}{*}{$\begin{array}{c}\text { em caso de estupro a mullher deve } \\
\text { abortar / estupro / em caso de estupro } \\
\text { / uma pessoa que foi estuprada ela } \\
\text { não vai ter que carregar o filho do cara } \\
\text { / ela pode abortar }\end{array}$} & $\begin{array}{c}\text { se ela não precisa carregar o } \\
\text { filho de um estuprador, ela pode } \\
\text { retirá-lo }\end{array}$ & & \multirow[b]{2}{*}{$\begin{array}{c}\text { Moral Emotiva / } \\
\text { Implicações para Vida da } \\
\text { Mãe }\end{array}$} \\
\hline $\begin{array}{c}\text { A174, } \\
\text { A176, L13 }\end{array}$ & $\begin{array}{l}\text { mesmo que fosse assim } \\
\text { uma pessoa que você } \\
\text { totalmente odeia...a pior } \\
\text { pessoa do mundo! [a mulher } \\
\text { odeia o estuprador] / é um } \\
\text { filho daquele cara safado! }\end{array}$ & & $\begin{array}{l}\text { o filho é uma lembrança de um } \\
\text { evento desagradável }\end{array}$ & \multirow{2}{*}{$\begin{array}{l}\text { em caso de } \\
\text { estupro }\end{array}$} & \\
\hline $\begin{array}{l}\text { B3, K23, } \\
\text { L11 }\end{array}$ & $\begin{array}{c}\text { a mulher não tem controle } \\
\text { sobre a situação/ela não } \\
\text { tem que carregar por causa } \\
\text { do bandido / essas } \\
\text { coisas...que ela não pôde } \\
\text { controlar nem nada.../ O } \\
\text { cara estupra a mulher...a } \\
\text { mulher tem que carregar o } \\
\text { filho do cara! Não! / ela não } \\
\text { tem que carregar por causa } \\
\text { do bandido }\end{array}$ & & $\begin{array}{l}\text { ninguém é obrigado a assumir } \\
\text { riscos oriundos de um } \\
\text { acontecimento sobre o qual não } \\
\text { se tem controle }\end{array}$ & & $\begin{array}{c}\text { Raciocínio Moral } \\
\text { Deontológico / Acidentes } \\
\text { e Não-Responsabilidade }\end{array}$ \\
\hline B3 & $\begin{array}{l}\text { a mulher não tem controle } \\
\text { sobre a situação / essas } \\
\text { coisas...que ela não pôde } \\
\text { controlar nem nada... }\end{array}$ & $\begin{array}{l}\text { em caso de risco de vida da mulher } \\
\text { ela deve poder abortar / quando a } \\
\text { mulher ta em risco de morrer [o aborto } \\
\text { deve ser permitido] / se o caso da } \\
\text { mulher também estiver em risco a vida }\end{array}$ & $\begin{array}{l}\text { ninguém é obrigado a assumir } \\
\text { riscos oriundos de um } \\
\text { acontecimento sobre o qual não } \\
\text { se tem controle }\end{array}$ & $\begin{array}{l}\text { em caso de risco } \\
\text { de vida / quando } \\
\text { a mulher ta em } \\
\text { risco de morrer / } \\
\text { se o caso da }\end{array}$ & $\begin{array}{c}\text { Raciocínio Moral } \\
\text { Deontológico / Acidentes } \\
\text { e Não-Responsabilidade }\end{array}$ \\
\hline
\end{tabular}




\begin{tabular}{|c|c|c|c|c|c|}
\hline $\begin{array}{c}\text { A2, L8, Kc, } \\
\mathrm{C} 4, \mathrm{C} 9 \\
\mathrm{C} 171, \mathrm{Ce} \\
\mathrm{Ae}^{*}, \mathrm{Be} \\
\mathrm{Ke}^{*}, \mathrm{Ce}\end{array}$ & & $\begin{array}{c}\text { dela / em risco de vida sim / somente } \\
\text { em um caso seria permitido: risco de } \\
\text { vida da mãe / concordo com o aborto } \\
\text { nos casos em que a gravidez corre } \\
\text { riscos de vida }\end{array}$ & & $\begin{array}{l}\text { mulher também } \\
\text { estiver em risco a } \\
\text { vida dela }\end{array}$ & $\begin{array}{l}\text { Moral Intuitiva / Valor } \\
\text { Relativo da Vida }\end{array}$ \\
\hline $\mathrm{Be}$ & & seria feito 0 aborto & & $\begin{array}{l}\text { [em caso de] risco } \\
\text { de vida da criança }\end{array}$ & $\begin{array}{c}\text { Moral Intuitiva / Respeito } \\
\text { à Vida - Valor Relativo da } \\
\text { Vida }\end{array}$ \\
\hline $\begin{array}{l}\text { B181, } \\
\text { K184, Be }\end{array}$ & & $\begin{array}{l}\text { eu concordo com a lei brasileira / eu } \\
\text { concordo com a lei }\end{array}$ & & & Moral Intuitiva \\
\hline B3, C171c & $\begin{array}{l}\text { a mulher não tem controle } \\
\text { sobre a situação / essas } \\
\text { coisas...que ela não pôde } \\
\text { controlar nem nada... }\end{array}$ & \multirow{2}{*}{$\begin{array}{l}\text { em caso de doença mental [não claro } \\
\text { se mãe ou filho] a mulher deve abortar } \\
\text { / [no caso de] alguma doença assim } \\
\text { né, problema mental [o aborto deve } \\
\text { ser permitido] / Seria feito o aborto }\end{array}$} & $\begin{array}{l}\text { ninguém é obrigado a assumir } \\
\text { riscos oriundos de um } \\
\text { acontecimento sobre o qual não } \\
\text { se tem controle }\end{array}$ & \multirow{2}{*}{$\begin{array}{c}\text { em caso de } \\
\text { doença mental } \\
\text { [não claro se mãe } \\
\text { ou filho] / alguma } \\
\text { doença assim né, } \\
\text { problema mental }\end{array}$} & $\begin{array}{l}\text { Raciocínio Moral } \\
\text { Deontológico / Acidentes } \\
\text { e Não-Responsabilidade }\end{array}$ \\
\hline $\mathrm{Be}$ & & & & & $\begin{array}{l}\text { Moral Intuitiva / Valor } \\
\text { Relativo da Vida }\end{array}$ \\
\hline $\mathrm{C} 40, \mathrm{C} 42$ & $\begin{array}{l}\text { tem muita criança hoje em } \\
\text { dia que tem filho com } \\
10 \ldots 10 \text { não, mas tipo } 12,13, \\
14 \text { anos que não morre no } \\
\text { parto e tem o filho... }\end{array}$ & $\begin{array}{l}\text { [mesmo caso a menina seja menor de } \\
\text { idade, ela não deve abortar] }\end{array}$ & $\begin{array}{c}\text { não é necessariamente morrer } \\
\text { no parto [a importância de } \\
\text { levar a cabo a gravidez é } \\
\text { maior que o risco que isso } \\
\text { representa a uma menor de } \\
\text { idade] }\end{array}$ & \multirow{3}{*}{$\begin{array}{l}\text { se for uma menor } \\
\text { de idade...nossa } \\
\text { idade mais ou } \\
\text { menos... }\end{array}$} & $\begin{array}{c}\text { Raciocínio Moral } \\
\text { Deontológico / Aceitação } \\
\text { de Riscos }\end{array}$ \\
\hline $\begin{array}{l}\text { B25, B27, } \\
\text { L37c }\end{array}$ & $\begin{array}{l}\text { ela não ta preparada o } \\
\text { corpo físico e mental não ta } \\
\text { nada preparado... }\end{array}$ & & $\begin{array}{l}\text { preparo físico e psicológico são } \\
\text { importantes para uma grávida }\end{array}$ & & $\begin{array}{l}\text { Raciocínio Moral } \\
\text { Consequencialista / } \\
\text { Evitar Riscos }\end{array}$ \\
\hline B39, B41 & $\begin{array}{l}\text { [gravidez e parto } \\
\text { representam risco de } \\
\text { vida]ela vai morrer no parto / } \\
\text { você tem risco de } \\
\text { morrer....ocê não deixa de } \\
\text { ter risco... }\end{array}$ & $\begin{array}{l}\text { caso a menina seja menor de idade } \\
\text { deve abortar / eu abortaria }\end{array}$ & o risco deve ser evitado & & $\begin{array}{l}\text { Moral Emotiva - } \\
\text { Raciocínio Moral } \\
\text { Consequencialista / } \\
\text { Evitar Riscos }\end{array}$ \\
\hline
\end{tabular}




\begin{tabular}{|c|c|c|c|c|c|}
\hline C63, L64 & $\begin{array}{c}\text { mesmo que foi uma coisa } \\
\text { não prevista por ela... } \\
\text { aconteceu }\end{array}$ & \multirow{4}{*}{$\begin{array}{l}\text { caso a menina fique grávida por } \\
\text { acidente tem que assumir o filho / se } \\
\text { responsabilizar pelo que fez / ela devia } \\
\text { assumir a criança / ela deveria... eu } \\
\text { acho que ela deveria asumir }\end{array}$} & Fatalismo & \multirow{9}{*}{$\begin{array}{l}\text { caso a menina } \\
\text { fique grávida por } \\
\text { acidente }\end{array}$} & $\begin{array}{l}\text { Raciocínio Moral } \\
\text { Deontológico / Riscos e } \\
\text { Responsabilidade }\end{array}$ \\
\hline $\mathrm{C} 63$ & $\begin{array}{l}\text { ela não foi obrigada a } \\
\text { transar com ele...foi uma } \\
\text { decisão conjunta... }\end{array}$ & & $\begin{array}{l}\text { tudo que é feito por vontade } \\
\text { própria deve ser assumido }\end{array}$ & & $\begin{array}{c}\text { Raciocínio Moral } \\
\text { Deontológico / Livre- } \\
\text { Arbítrio e } \\
\text { Responsabilidade }\end{array}$ \\
\hline $\mathrm{C} 63$ & $\begin{array}{l}\text { eles sabiam dos riscos que } \\
\text { poderia ter...depois }\end{array}$ & & $\begin{array}{l}\text { conhecimento dos riscos implica } \\
\text { responsabilidade }\end{array}$ & & $\begin{array}{l}\text { Raciocínio Moral } \\
\text { Deontológico / Riscos e } \\
\text { Responsabilidade }\end{array}$ \\
\hline $\begin{array}{l}\mathrm{A} 69, \mathrm{Ce} \\
\mathrm{Ae}, \mathrm{Ke}\end{array}$ & & & & & $\begin{array}{l}\text { Moral Intuitiva / Riscos e } \\
\text { Responsabilidade }\end{array}$ \\
\hline C63 / L64 & pra poder sustentar o filho & \multirow{3}{*}{$\begin{array}{l}\text { devia trancar a faculdade (...) e } \\
\text { procurar um trabalho / eles deverão } \\
\text { trancar os estudos e depois...mais pra } \\
\text { frente quando quiserem voltar eles } \\
\text { voltam.../ tentar...parar um pouco os } \\
\text { estudos } / \text { ele devia parar o estudo dele } \\
\text { pra trabalhar / deviam fazer algum } \\
\text { plano pra vida / quando o filho } \\
\text { começar a crescer muito eu acho que } \\
\text { ela deveria parar por algum } \\
\text { tempo...parar de estudar... }\end{array}$} & $\begin{array}{l}\text { é necessário trabalhar para } \\
\text { sustentar um filho }\end{array}$ & & $\begin{array}{c}\text { Raciocínio Moral } \\
\text { Consequencialista / } \\
\text { Ambição e Segurança } \\
\text { Financeira }\end{array}$ \\
\hline $\mathrm{C} 74$ & $\begin{array}{l}\text { não dá pra criar uma criança } \\
\text { do nada... }\end{array}$ & & $\begin{array}{l}\text { os dois fizeram...os dois } \\
\text { assumem... }\end{array}$ & & $\begin{array}{l}\text { Raciocínio Moral } \\
\text { Consequencialista / } \\
\text { Ambição e Segurançaa } \\
\text { Financeira - Cuidado } \\
\text { Parental }\end{array}$ \\
\hline $\begin{array}{l}\text { A69, K73, } \\
\text { A81 }\end{array}$ & & & & & \multirow{2}{*}{$\begin{array}{l}\text { Moral Intuitiva / Cuidado } \\
\text { Parental }\end{array}$} \\
\hline $\mathrm{Ae}$ & & & & & \\
\hline C78, A79c & $\begin{array}{l}\text { se ela fosse trabalhar por } \\
\text { exemplo como atendente de } \\
\text { lanchonete até ficar sei lá } \\
\text { com } 9 \text { meses } 8,7 \ldots \text {,..ela não } \\
\text { tem nenhuma ...nada } \\
\text { pesado nada desse tipo... }\end{array}$ & $\begin{array}{l}\text { a Jane podia trabalhar / Jane deveria } \\
\text { trabalhar e mais tarde ela amamenta o } \\
\text { bebê e recomeça os estudos }\end{array}$ & $\begin{array}{l}\text { uma mulher grávida com } \\
\text { dificuldades financeiras pode } \\
\text { e/ou deve trabalhar em serviços } \\
\text { que não sejam pesados }\end{array}$ & & $\begin{array}{l}\text { Raciocínio Moral } \\
\text { Consequencialista/ } \\
\text { Ambição e Segurança } \\
\text { Financeira - Cuidado } \\
\text { Parental }\end{array}$ \\
\hline
\end{tabular}




\begin{tabular}{|c|c|c|c|c|c|}
\hline $\mathrm{C} 80$ & & $\begin{array}{c}\text { ela pode estudar durante a gravidez } \\
\text { dela também }\end{array}$ & & & $\begin{array}{l}\text { Moral Intuitiva / Ambição } \\
\text { e Segurança Financeira }\end{array}$ \\
\hline $\begin{array}{l}\mathrm{L} 82, \mathrm{Ce} \\
\mathrm{Ae}\end{array}$ & & $\begin{array}{c}\text { quando o filho tiver uns } 7 \text { meses pode } \\
\text { parar [de estudar]... } 7 \text { ou } 8 \text { de } \\
\text { gravidez... aí o filho nasceu aí ela } \\
\text { pode amamentar ele e depois que ele } \\
\text { estiver um pouco mais crescido pode } \\
\text { deixar com os avós... / [ela deveria] } \\
\text { continuar estudando ficar com } 7 \text { de } \\
\text { gravidez e trancar a faculdade neste } \\
\text { período / tentar mais tarde fazer a } \\
\text { faculdade }\end{array}$ & & & $\begin{array}{l}\text { Moral Intuitiva / Cuidado } \\
\text { Parental - Ambição e } \\
\text { Segurança Financeira }\end{array}$ \\
\hline $\mathrm{C} 76$ & ela tá grávida... & ele tem que parar os estudos & $\begin{array}{l}\text { precisa de alguém pra cuidar } \\
\text { dela }\end{array}$ & & $\begin{array}{c}\text { Raciocínio Moral } \\
\text { Deontológico / Cuidado } \\
\text { Parental }\end{array}$ \\
\hline $\begin{array}{l}\text { L75, Ce, } \\
\mathrm{Ke}\end{array}$ & & $\begin{array}{l}\text { ela deveria assim... parar de estudar } \\
\text { enquanto o filho não nasce.../ Ele } \\
\text { deveria ajudar Jane, trancar a } \\
\text { faculdade ou então trabalhar / parar de } \\
\text { estudar até o bebê nascer }\end{array}$ & & & $\begin{array}{c}\text { Moral Intuitiva / Cuidado } \\
\text { Parental }\end{array}$ \\
\hline $\mathrm{C} 74$ & $\begin{array}{l}\text { não dá pra criar uma criança } \\
\text { do nada... }\end{array}$ & $\begin{array}{l}\text { [ela deve] pedir ajudar pros pais / pedir } \\
\text { ajuda pra família / talvez ela pudesse }\end{array}$ & $\begin{array}{l}\text { os dois fizeram....os dois } \\
\text { assumem... }\end{array}$ & & $\begin{array}{c}\text { Raciocínio Moral } \\
\text { Consequencialista / } \\
\text { Ambição e Segurança } \\
\text { Financeira - Cuidado } \\
\text { Parental }\end{array}$ \\
\hline $\begin{array}{l}\text { C63, A77, } \\
\text { Ae }\end{array}$ & & $\begin{array}{l}\text { ajudar durante esse estágio / os pais } \\
\text { devem ajudar }\end{array}$ & & & $\begin{array}{c}\text { Moral Intuitiva / Cuidado } \\
\text { Parental }\end{array}$ \\
\hline $\mathrm{Ae}, \mathrm{Ke}$ & & $\begin{array}{l}\text { ele não precisa parar com os estudos / } \\
\text { Ele deveria continuar os estudos à } \\
\text { noite / Ele deveria trabalhar meio }\end{array}$ & & $\begin{array}{l}\text { caso a menina } \\
\text { fique grávida por } \\
\text { acidente }\end{array}$ & $\begin{array}{l}\text { Moral Intuitiva / Ambição } \\
\text { e Segurança Financeira }\end{array}$ \\
\hline
\end{tabular}




\begin{tabular}{|c|c|c|c|c|}
\hline L75, A77c & $\begin{array}{l}\text { Como ele ta entrando em } \\
\text { um curso de engenharia } \\
\text { agora...eu acho que ele } \\
\text { deveria entrar em uma } \\
\text { empresa pra fazer um } \\
\text { estágio de mannhã e fazer a } \\
\text { faculdade a noite, o curso } \\
\text { (...) ele vai conseguir um } \\
\text { trabalho... }\end{array}$ & período e estudar à noite & assim é bem melhor & $\begin{array}{l}\text { Raciocínio Moral } \\
\text { Consequencialista / } \\
\text { Ambição e Segurança } \\
\text { Financeira }\end{array}$ \\
\hline L64 & & \multirow{3}{*}{$\begin{array}{c}\text { ele tem que se responsabilizar pela } \\
\text { criança não só a mãe quanto o outro } \\
\text { cara...o namorado dela... / os dois são } \\
\text { responsáveis, tanto o pai quanto a } \\
\text { mãe / juntos ter o filho e } \\
\text { assumir...claro... }\end{array}$} & & $\begin{array}{c}\text { Moral Intuitiva / Cuidado } \\
\text { Parental }\end{array}$ \\
\hline $\mathrm{C} 65, \mathrm{C} 74$ & $\begin{array}{l}\text { porque aqui eles tiveram } \\
\text { uma decisão conjunta / } \\
\text { porque é responsabilidade } \\
\text { dos dois. }\end{array}$ & & $\begin{array}{l}\text { tudo que é feito por vontade } \\
\text { própria deve ser assumido }\end{array}$ & $\begin{array}{l}\text { Raciocínio Moral } \\
\text { Deontológico / Livre- } \\
\text { Arbítrio e } \\
\text { Responsabilidade }\end{array}$ \\
\hline $\mathrm{C} 65$ & $\begin{array}{l}\text { o aborto é como se fosse } \\
\text { matar uma vida }\end{array}$ & & matar é errado & $\begin{array}{c}\text { Raciocínio Moral } \\
\text { Deontológico / Respeito } \\
\text { à Vida }\end{array}$ \\
\hline B68 & & \multirow{2}{*}{$\begin{array}{l}\text { [caso a menina fique grávida por } \\
\text { acidente] deveria abortar, eu ia } \\
\text { abortar... Se fosse no meu lugar eu } \\
\text { faria: eu abortaria }\end{array}$} & & $\begin{array}{l}\text { Moral Intuitiva - Moral } \\
\text { Emotiva / Implicaçỗes } \\
\text { Vida da Mãe }\end{array}$ \\
\hline $\mathrm{Be}$ & $\begin{array}{l}\text { não teria condições de tê-lo } \\
\text { [o bebê] }\end{array}$ & & $\begin{array}{l}\text { assim seria melhor para ele e } \\
\text { para mim }\end{array}$ & $\begin{array}{c}\text { Moral Emotiva - } \\
\text { Raciocínio Moral } \\
\text { Consequencialista / } \\
\text { Implicaçōos Vida da Mãe }\end{array}$ \\
\hline $\mathrm{Ce}$ & $\begin{array}{l}\text { pois se o zigoto se fixa no } \\
\text { útero após } 30 \mathrm{~h}\end{array}$ & \multirow[t]{2}{*}{$\begin{array}{l}\text { a pílula do dia seguinte não deveria } \\
\text { ser liberada / seria proibida / não acho } \\
\text { que deveria ser liberado... }\end{array}$} & $\begin{array}{l}\text { quando você tomasse a pilula, } \\
\text { você descamaria o útero e } \\
\text { mataria o embriâo formado }\end{array}$ & $\begin{array}{c}\text { Raciocínio Moral } \\
\text { Consequencialista / } \\
\text { Limites da Vida - } \\
\text { Raciocínio Moral } \\
\text { Deontológico / Respeito } \\
\text { à Vida - Conceitos (ação } \\
\text { da pílula) }\end{array}$ \\
\hline $\begin{array}{l}\text { K154, } \\
\text { K156, } \\
\text { K162 }\end{array}$ & eu sou contra o aborto & & $\begin{array}{l}\text { a pílula do dia seguinte é um } \\
\text { método abortivo }\end{array}$ & $\begin{array}{l}\text { Raciocínio Moral } \\
\text { Deontológico / Regras e } \\
\text { Aplicabilidade }\end{array}$ \\
\hline
\end{tabular}




\begin{tabular}{|c|c|c|c|c|}
\hline K160 & $\begin{array}{l}\text { se você toma a pílula do dia } \\
\text { seguinte você ta matando }\end{array}$ & & matar é errado & $\begin{array}{c}\text { Raciocínio Moral } \\
\text { Deontológico / Respeito } \\
\text { à Vida }\end{array}$ \\
\hline $\begin{array}{l}\text { C127, } \\
\text { C129 }\end{array}$ & $\begin{array}{c}\text { você considera o momento } \\
\text { de vida quando o zigoto se } \\
\text { fixa no útero / se ele se fixou } \\
\text { no útero }\end{array}$ & $\begin{array}{l}\text { o zigoto que tava implantado vai } \\
\text { morrer, vai desimplantar, vai ser } \\
\text { destruído, ou seja, aquela vida que } \\
\text { você disse que teria...vai pro espaço... }\end{array}$ & $\begin{array}{l}\text { você usar a pílula do dia } \\
\text { seguinte vai descamar o seu } \\
\text { útero }\end{array}$ & $\begin{array}{c}\text { Raciocínio Moral } \\
\text { Consequencialista / } \\
\text { Limites da Vida - } \\
\text { Raciocínio Moral } \\
\text { Deontológico / Respeito } \\
\text { à Vida - Conceitos (ação } \\
\text { da pílula) }\end{array}$ \\
\hline L130 & & $\begin{array}{l}\text { a pílula do dia seguinte são só depois } \\
\text { de } 48 \text { horas }\end{array}$ & & $\begin{array}{l}\text { Moral Intuitiva / } \\
\text { Conceitos (ação da } \\
\text { pílula) }\end{array}$ \\
\hline C131 & & ele fixa depois de 30horas... & & $\begin{array}{l}\text { Moral Intuitiva / } \\
\text { Conceitos (nidação) }\end{array}$ \\
\hline C133 & & \multirow[b]{2}{*}{$\begin{array}{l}\text { a pílula do dia seguinte é um método } \\
\text { abortivo / então você vai ter uma } \\
\text { vida...vai lá e você vai matar uma } \\
\text { vida.... na utilizaçãa da pílula do dia } \\
\text { seguintet / pílula do dia seguinte } \\
\text { também é matar o seu filho }\end{array}$} & & $\begin{array}{c}\text { Moral Intuitiva / Respeito } \\
\text { à Vida }\end{array}$ \\
\hline C16, C18 & $\begin{array}{l}\text { ele [o embrião] se formou a } \\
\text { partir do momento em que o } \\
\text { óvulo e o espermatozóide se } \\
\text { unem pode ter uma vida la' }\end{array}$ & & $\begin{array}{l}\text { a pílula do dia seguinte pode agir } \\
\text { após a fecundação }\end{array}$ & $\begin{array}{c}\text { Raciocínio Moral } \\
\text { Consequencialista / } \\
\text { Limites da Vida - } \\
\text { Raciocínio Moral } \\
\text { Deontológico / Respeito } \\
\text { à Vida - Conceitos (ação } \\
\text { da pílula) }\end{array}$ \\
\hline $\begin{array}{l}\text { L134, } \\
\text { L136 }\end{array}$ & & $\begin{array}{l}\text { eu ainda acho que isso é diferente... } \\
\text { [com relação à pílula do dia seguinte } \\
\text { ser equivalente ao aborto] / eu não } \\
\text { acho e pronto }\end{array}$ & & Moral Intuitiva \\
\hline L17 & $\begin{array}{l}\text { o embrião ainda nem se } \\
\text { formou }\end{array}$ & $\begin{array}{c}\text { Claro que não [a pílula do dia seguinte } \\
\text { não é matar o filho] }\end{array}$ & $\begin{array}{l}\text { o zigoto ainda não pode ser } \\
\text { equiparado ao filho em termos } \\
\text { de status moral }\end{array}$ & $\begin{array}{l}\text { Raciocínio Moral } \\
\text { Deontológico / Valor } \\
\text { Relativo da Vida - } \\
\text { Conceitos (ação da } \\
\text { pílula) }\end{array}$ \\
\hline
\end{tabular}




\begin{tabular}{|c|c|c|c|c|c|}
\hline $\begin{array}{l}\text { B146, } \\
\text { B148, } \\
\text { B150, Be }\end{array}$ & [é] uma boa causa lógico & $\begin{array}{l}\text { eu até deixaria...eu aceitaria no meu } \\
\text { país (...) daí ela poderia tomar a pílula } \\
\text { do dia seguinte.../ seria permitida / a } \\
\text { pílula do dia seguinte deveria ser } \\
\text { liberada no caso de estupro/ ou } \\
\text { quando a menina for menor e na } \\
\text { presença dos pais }\end{array}$ & $\begin{array}{l}\text { faz sentido permitir que a mulher } \\
\text { não tenha o filho quando for } \\
\text { menor de idade ou estuprada }\end{array}$ & $\begin{array}{l}\text { depende do caso } \\
\text { / no caso de } \\
\text { estupro ou (...) se } \\
\text { fosse uma menor } \\
\text { de idade quando } \\
\text { a menina for } \\
\text { menor (...) na } \\
\text { presença dos pais } \\
\text { / estupro, e no } \\
\text { caso de um } \\
\text { acidente da } \\
\text { camisinha a } \\
\text { menina que no } \\
\text { caso se for uma } \\
\text { menor de idade, } \\
\text { á com a } \\
\text { presença dos pais } \\
\text { ela poderia tomar }\end{array}$ & $\begin{array}{l}\text { Moral Emotiva / Direitos } \\
\text { da Mulher - Evitar Riscos }\end{array}$ \\
\hline B152 & é um caso extremo & $\begin{array}{l}\text { eu até deixaria...eu aceitaria no meu } \\
\text { país (...) dá ela poderia tomar a pílula } \\
\text { do dia seguinte.../ seria permitida / a } \\
\text { pílula do dia seguinte deveria ser } \\
\text { liberada no caso de estupro/ ou } \\
\text { quando a menina for menor e na } \\
\text { presença dos pais }\end{array}$ & $\begin{array}{l}\text { estupro é um caso especial que } \\
\text { permite que a mulher não tenha } \\
\text { o filho }\end{array}$ & $\begin{array}{l}\text { no caso de } \\
\text { estupro }\end{array}$ & $\begin{array}{l}\text { Moral Emotiva / Casos } \\
\text { Extremos e Exceções }\end{array}$ \\
\hline
\end{tabular}




\section{Anexo IV Grupo E}

Cinza: partes do argumento que não pertencem àquela categoria

Negrito: a garantia está explícita

"c": o aluno não disse o argumento, mas concordou com ele

* Subargumentos ramificados da refutacão do argumento anterior

\begin{tabular}{|c|c|c|c|c|c|c|}
\hline \multirow{2}{*}{$\begin{array}{l}\text { Aluno e } \\
\text { Enunciado }\end{array}$} & \multicolumn{5}{|c|}{ Argumentos ou Asserções } & \multirow[b]{2}{*}{ Padrão Moral / Valor } \\
\hline & Dado (dado que...) & Conclusão/Asserção & Garantia (já que...) & Qualificador & $\begin{array}{l}\text { Refutador (a menos } \\
\text { que...) }\end{array}$ & \\
\hline G3, G5 & $\begin{array}{c}\text { a partir do momento } \\
\text { em que uma mulher } \\
\text { está para ter um filho e } \\
\text { ela não quer ter esse } \\
\text { filho } \\
\end{array}$ & $\begin{array}{c}\text { deveria permitir em qualquer caso [o } \\
\text { aborto] }\end{array}$ & ela tem o direito de abortar & em qualquer caso & & $\begin{array}{c}\text { Raciocínio Moral } \\
\text { Deontológico / Direitos } \\
\text { da Mulher }\end{array}$ \\
\hline M7, Me & $\begin{array}{c}\text { todo mundo ia querer } \\
\text { fazer sexo e ia querer } \\
\text { abortar / se ele fosse } \\
\text { legalizado todos fariam } \\
\text { sexo sem segurança e } \\
\text { veriam o aborto como } \\
\text { uma solução para seus } \\
\text { problemas }\end{array}$ & \multirow[t]{2}{*}{ não acho que devia legalizar } & $\begin{array}{l}\text { não tá certo [todo mundo } \\
\text { querer fazer sexo e abortar] }\end{array}$ & & & $\begin{array}{l}\text { Raciocínio Moral } \\
\text { Consequencialista / } \\
\text { Ordem Social }\end{array}$ \\
\hline M7 & $\begin{array}{l}\text { você tá matando um } \\
\text { bebê }\end{array}$ & & $\begin{array}{l}\text { [matar o bebê] é errado, como } \\
\text { se matasse uma pessoa }\end{array}$ & & $\begin{array}{l}1 \text { a pessoa fosse } \\
\text { estuprada } 2 \text { não tem } \\
\text { condições de criar }\end{array}$ & $\begin{array}{c}\text { Raciocínio Moral } \\
\text { Deontológico / Respeito } \\
\text { à Vida }\end{array}$ \\
\hline$M 7^{*}$ & $\begin{array}{l}\text { se a pessoa fosse } \\
\text { estuprada }\end{array}$ & \multirow{2}{*}{ deveria ser permitido } & \multirow{2}{*}{$\begin{array}{c}\text { levar pra adoção também não } \\
\text { adianta }\end{array}$} & \multirow{2}{*}{ só } & & \multirow{2}{*}{$\begin{array}{l}\text { Raciocínio Moral } \\
\text { Consequencialista / } \\
\text { Ordem Social }\end{array}$} \\
\hline$M 7^{*}$ & $\begin{array}{l}\text { ou se não tem } \\
\text { condições de criar }\end{array}$ & & & & & \\
\hline M107, M109 & $\begin{array}{l}\text { porque mesmo que o } \\
\text { bebê nasça, ele vai } \\
\text { ficar sem a mãe }\end{array}$ & $\begin{array}{l}\text { se apresentar risco de vida pra mãe [o } \\
\text { aborto deve ser permitido] }\end{array}$ & $\begin{array}{c}\text { vai ser um problema pro filho } \\
\text { [é um problema nascer sem } \\
\text { mãe] }\end{array}$ & $\begin{array}{l}\text { se apresentar } \\
\text { risco de vida pra } \\
\text { mãe }\end{array}$ & & $\begin{array}{c}\text { Raciocínio Moral } \\
\text { Consequencialista / } \\
\text { Ordem Social - Cuidado } \\
\text { Parental }\end{array}$ \\
\hline 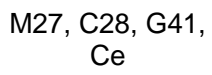 & & $\begin{array}{l}\text { [o aborto] pode ser permitido se a mãe } \\
\text { não tem condições de criar / poderá }\end{array}$ & & $\begin{array}{l}\text { dependendo do } \\
\text { caso / se não tem }\end{array}$ & & $\begin{array}{l}\text { Moral Intuitiva / Ambição } \\
\text { e Segurança Financeira }\end{array}$ \\
\hline
\end{tabular}




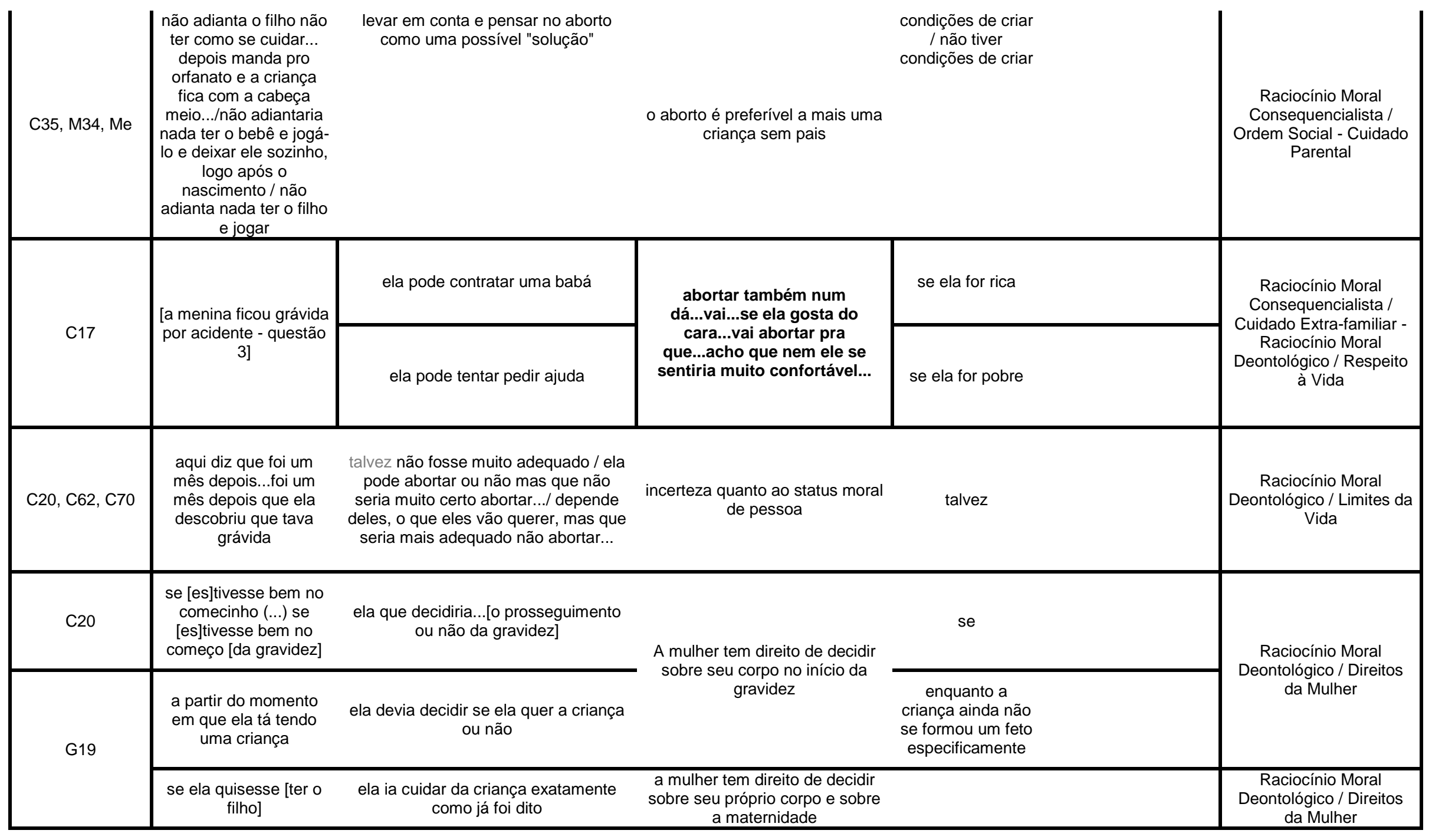




\begin{tabular}{|c|c|c|c|c|c|c|}
\hline & $\begin{array}{c}\text { se ela não quisesse a } \\
\text { criança }\end{array}$ & ela abortava... & & & & \\
\hline \multirow[t]{2}{*}{ G22 } & $\begin{array}{l}\text { eles ainda seriam } \\
\text { muito jovens pra ter um } \\
\text { filho }\end{array}$ & ele devia propor pra ela um aborto & $\begin{array}{c}\text { um casal muito jovem não terá } \\
\text { condições adequadas para criar } \\
\text { um filho }\end{array}$ & \multirow[t]{4}{*}{$\begin{array}{l}\text { [se a menina ficou } \\
\text { grávida por } \\
\text { acidente - } \\
\text { questões } 3 \text { e 4] }\end{array}$} & $\begin{array}{c}\text { eles poderiam tentar } \\
\text { decidir ter uma vida } \\
\text { juntos e procurar um } \\
\text { novo trabalho e...se } \\
\text { eles tivessem uma } \\
\text { vida feliz assim, que } \\
\text { bom... }\end{array}$ & $\begin{array}{l}\text { Raciocínio Moral } \\
\text { Consequencialista / } \\
\text { Planejamento Familiar }\end{array}$ \\
\hline & & $\begin{array}{l}\text { eles poderiam tentar decidir ter uma } \\
\text { vida juntos e procurar um novo } \\
\text { trabalho e...se eles tivessem uma vida } \\
\text { feliz assim, que bom... }\end{array}$ & & & & $\begin{array}{c}\text { Moral Intuitiva / } \\
\text { Manutenção de Relações } \\
\text { - Ambição e Segurança } \\
\text { Financeira }\end{array}$ \\
\hline $\mathrm{Ce}$ & & \multirow{2}{*}{$\begin{array}{l}\text { eles poderiam conciliar...tipo enquanto } \\
\text { ela estudava de manhã ele cuidava do } \\
\text { filho de manhã e enquanto ele } \\
\text { estudava de tarde e ela cuidava do } \\
\text { filho de tarde / o mais correto seria } \\
\text { eles conciliarem a criança e o estudo }\end{array}$} & & & & $\begin{array}{c}\text { Moral Intuitiva / Cuidado } \\
\text { Parental / Ambição e } \\
\text { Segurança Financeira }\end{array}$ \\
\hline $\mathrm{C} 23$ & $\begin{array}{c}\text { se ele largar a } \\
\text { universidade ele...pode } \\
\text { acabar com a carreira } \\
\text { dele }\end{array}$ & & $\begin{array}{c}\text { ele poderia sei lá...continuar } \\
\text { na universidade (...)aí ele se } \\
\text { formava, eles podiam ganhar } \\
\text { bem e dar uma boa vida pro } \\
\text { bebê... }\end{array}$ & & & \multirow[b]{2}{*}{$\begin{array}{c}\text { Raciocínio Moral } \\
\text { Consequencialista / } \\
\text { Ambição e Segurança } \\
\text { Financeira - Cuidado } \\
\text { Parental }\end{array}$} \\
\hline M24, M82, Me & $\begin{array}{c}\text { pra não ficar muito } \\
\text { pesado pra nenhum } \\
\text { dos dois (...) porque } \\
\text { senão ficaria muito } \\
\text { pesado pra um dos } \\
\text { dois / porque também } \\
\text { não seria justo ela } \\
\text { também ter que parar } \\
\text { de estudar para cuidar } \\
\text { do bebe enquanto ele } \\
\text { faz as coisas dele / não } \\
\text { seria justo apenas } \\
\text { Jane largar tudo para } \\
\text { ser mãe }\end{array}$ & $\begin{array}{l}\text { eles tinham que se dividir(...)ele não } \\
\text { precisaria parar totalmente de } \\
\text { estudar...ele podia estudar de noite e } \\
\text { trabalhar de manhã ou de tarde.../ no } \\
\text { horário dele cuidar do filho a Jane } \\
\text { poderia estudar continuar os estudos } \\
\text { dela / Eles deveriam conversar e os } \\
\text { dois conciliarem tudo }\end{array}$ & $\begin{array}{c}\text { nenhum dos dois pode nem } \\
\text { trabalhar mais nem perder } \\
\text { nada... / para nenhuma das } \\
\text { partes serem afetadas }\end{array}$ & $\begin{array}{l}\text { - [se a menina ficou } \\
\text { grávida por } \\
\text { acidente - } \\
\text { questões } 3 \text { e 4] }\end{array}$ & & \\
\hline
\end{tabular}




\begin{tabular}{|c|c|c|c|c|c|c|}
\hline M24 & $\begin{array}{l}\text { porque se o bebê for } \\
\text { criado por uma babá } \\
\text { ele vai ficar com a } \\
\text { cabeça totalmente... }\end{array}$ & colocar uma babá seria muito ruim & $\begin{array}{l}\text { porque ele não vai poder ver os } \\
\text { pais nunca se os dois estão indo } \\
\text { trabalhar e estudar, eles nunca } \\
\text { vão ter tempo pro filho então } \\
\text { eles não vão poder ter uma } \\
\text { relação boa, como uma família } \\
\text { de verdade }\end{array}$ & & & $\begin{array}{l}\text { Raciocínio Moral } \\
\text { Consequencialista / } \\
\text { Cuidado Parental }\end{array}$ \\
\hline $\mathrm{C} 86, \mathrm{C} 88, \mathrm{Ce}$ & $\begin{array}{l}\text { se eles tiverem boa } \\
\text { vontade }\end{array}$ & $\begin{array}{c}\text { ela devia conciliar as duas coisas...ela } \\
\text { não tinha que parar de trabalhar } \\
\text { totalmente, ela deveria pedir uma } \\
\text { licença e tudo / dá pra conciliar o } \\
\text { trabalho e a criança }\end{array}$ & $\begin{array}{l}\text { havendo boa vontade, as } \\
\text { pessoas conseguem dar conta } \\
\text { de mais responsabilidades }\end{array}$ & & & $\begin{array}{c}\text { Raciocínio Moral } \\
\text { Consequencialista / } \\
\text { Cuidado Parental - } \\
\text { Ambição e Segurança } \\
\text { Financeira }\end{array}$ \\
\hline M18 & pra cuidar do bebê & $\begin{array}{c}\text { ela devia conciliar as duas coisas...ela } \\
\text { não tinha que parar de trabalhar } \\
\text { totalmente, ela deveria pedir uma } \\
\text { licença e tudo / dá pra conciliar o } \\
\text { trabalho e a criança }\end{array}$ & $\begin{array}{l}\text { a mulher deve ajustar sua vida } \\
\text { para exercer a maternidade }\end{array}$ & & \multirow{2}{*}{$\begin{array}{l}\text { mas chegaria uma } \\
\text { hora que depois o } \\
\text { bebê crescessee, tudo } \\
\text { bem e tal....quandoo } \\
\text { ficasse um pouco } \\
\text { mais vello tipo um } \\
\text { ano ou dois...podia } \\
\text { contratar uma babá } \\
\text { por um determinado } \\
\text { período e trabalhar } \\
\text { tipo de manhãa até de } \\
\text { tarde ou de tarde até a a } \\
\text { noite, pra poder ficar } \\
\text { um pouco com o bebê } \\
\text { também pra ele não } \\
\text { se sentir muito } \\
\text { sozinho e não ter } \\
\text { problema mais pra } \\
\text { frente... }\end{array}$} & $\begin{array}{l}\text { Raciocínio Moral } \\
\text { Consequencialista / } \\
\text { Cuidado Parental - } \\
\text { Ambição e Segurança } \\
\text { Financeira }\end{array}$ \\
\hline M18, M82, Me & $\begin{array}{l}\text { pra ter uma renda pra } \\
\text { cuidar do bebê.../ um } \\
\text { dos dois vai ter que } \\
\text { trabalhar pra poder dar } \\
\text { um bom futuro pro } \\
\text { filho... }\end{array}$ & $\begin{array}{l}\text { o namorado, marido dela continuar } \\
\text { trabalhando / ele não deveria parar de } \\
\text { trabalhar por causa do bebe (...) } \\
\text { deveria trabalhar em certo periodo e } \\
\text { estudar de noite e também.../ não } \\
\text { precisaria parar de trabalhar apenas } \\
\text { mudar o seu cotidiano para um que } \\
\text { beneficie não somente o pai mas a } \\
\text { Jane também }\end{array}$ & $\begin{array}{l}\text { um bebê demanda custos que } \\
\text { pai deve conseguir pagar }\end{array}$ & $\begin{array}{l}\text { [se a menina ficou } \\
\text { grávida por } \\
\text { acidente - } \\
\text { questōes } 3 \text { e 4] }\end{array}$ & & $\begin{array}{l}\text { Raciocínio Moral } \\
\text { Consequencialista / } \\
\text { Cuidado Parental - } \\
\text { Ambição e Segurança } \\
\text { Financeira }\end{array}$ \\
\hline
\end{tabular}




\begin{tabular}{|c|c|c|c|c|c|c|}
\hline M18* & $\begin{array}{l}\text { pra poder ficar um } \\
\text { pouco com o bebê } \\
\text { também }\end{array}$ & $\begin{array}{c}\text { podia contratar uma babá por um } \\
\text { determinado período e trabalhar tipo } \\
\text { de manhã ate de tarde ou de tarde até } \\
\text { a noite }\end{array}$ & $\begin{array}{c}\text { pra ele não se sentir muito } \\
\text { sozinho e não ter problema } \\
\text { mais pra frente... }\end{array}$ & $\begin{array}{l}\text { depois [que] o } \\
\text { bebê crescesse, } \\
\text { tudo bem e } \\
\text { tal...quando } \\
\text { ficasse um pouco } \\
\text { mais velho tipo } \\
\text { um ano ou dois... }\end{array}$ & & $\begin{array}{l}\text { Raciocínio Moral } \\
\text { Consequencialista / } \\
\text { Cuidado Parental }\end{array}$ \\
\hline M71 & $\begin{array}{l}\text { como eles já são } \\
\text { quase adultos }\end{array}$ & $\begin{array}{l}\text { eles deviam pensar muito bem antes } \\
\text { de tomar qualquer decisão }\end{array}$ & $\begin{array}{l}\text { porque eles estariam matando } \\
\text { um feto, filho deles [caso } \\
\text { resolvessem pelo aborto] }\end{array}$ & & & $\begin{array}{c}\text { Raciocínio Moral } \\
\text { Consequencialista / Valor } \\
\text { Relativo da Vida }\end{array}$ \\
\hline M71 & $\begin{array}{l}\text { com } 18 \text { anos eles } \\
\text { ainda não...com } 16 \\
\text { anos eles num sabem } \\
\text { ainda muito bem o que } \\
\text { eles querem......)pra } \\
\text { não perder a vida } \\
\text { particular deles (...)pra } \\
\text { não perder em nada a } \\
\text { juventude deles } \\
\end{array}$ & $\begin{array}{c}\text { deviam (...) conciliar os estudos, sabe, } \\
\text { dividir cada um.......) então eles } \\
\text { deviam não parar de estudar, (...) } \\
\text { então eles deviam conciliar um com } \\
\text { outro }\end{array}$ & $\begin{array}{l}\text { é importante para a formação } \\
\text { deles / porque eles também } \\
\text { precisam disso... }\end{array}$ & & & $\begin{array}{l}\text { Raciocínio Moral } \\
\text { Consequencialista / } \\
\text { Ambição e Segurança } \\
\text { Financeira - Cuidado } \\
\text { Parental }\end{array}$ \\
\hline M71, Ce & $\begin{array}{l}\text { se eles se gostam } \\
\text { assim de verdade / se } \\
\text { eles se gostam não há } \\
\text { motivo para abortar }\end{array}$ & $\begin{array}{l}\text { não há motivo para abortar / eles } \\
\text { deviam cuidar do filho juntos }\end{array}$ & $\begin{array}{l}\text { casais que se gostam devem } \\
\text { aceitar constituir família }\end{array}$ & & & $\begin{array}{c}\text { Raciocínio Moral } \\
\text { Deontológico - Moral } \\
\text { Emotiva / Manutenção de } \\
\text { Relações }\end{array}$ \\
\hline G69 & $\begin{array}{l}\text { levando em } \\
\text { consideração que eles } \\
\text { não planejavam } \\
\text { engravidar }\end{array}$ & eu acho que eles deviam abortar & $\begin{array}{c}\text { provavelmente por enquanto } \\
\text { ela ainda não quer começar a } \\
\text { trabalhar, ter um filhoo e cuidar } \\
\text { da família e blábláblá }\end{array}$ & $\begin{array}{l}1 \text { caso a menina } \\
\text { fique grávida por } \\
\text { acidente } 2 \text { se } \\
\text { ela não quer a } \\
\text { criança }\end{array}$ & $\begin{array}{c}\text { mas caso eles } \\
\text { aceitem a ideia de } \\
\text { cuidar do bebê, mudar } \\
\text { de trabalho, pagar, } \\
\text { cuidar da própria vida } \\
\text { e blábláblá, eles } \\
\text { podem não abortar e } \\
\text { ter o filho... }\end{array}$ & $\begin{array}{l}\text { Raciocínio Moral } \\
\text { Consequencialista / } \\
\text { Planejamento Familiar }\end{array}$ \\
\hline
\end{tabular}




\begin{tabular}{|c|c|c|c|c|c|c|}
\hline G69* & $\begin{array}{l}\text { caso eles aceitem a } \\
\text { ideia de cuidar do } \\
\text { bebê, mudar de } \\
\text { trabalho, pagar, cuidar } \\
\text { da própria vida e } \\
\text { blábláblá }\end{array}$ & eles podem não abortar e ter o filho... & $\begin{array}{l}\text { ter filhos exige mudanças nos } \\
\text { projetos e esquemas de vida }\end{array}$ & $\begin{array}{l}1 \text { caso a menina } \\
\text { fique grávida por } \\
\text { acidente } 2 \text { se } \\
\text { ela quer a criança }\end{array}$ & & \\
\hline C8, C10 & $\begin{array}{l}\text { que...vai ser uma } \\
\text { pessoa }\end{array}$ & não é certo matar uma criança & $\begin{array}{c}\text { é um assassinato quase...só } \\
\text { que antes de ela se } \\
\text { desenvolver }\end{array}$ & & $\begin{array}{l}\text { em alguns casos } \\
\text { poderia levar em } \\
\text { conta tipo por } \\
\text { exemplo...que nem ela } \\
\text { falou...se for } \\
\text { estuprada...e também } \\
\text { se for estuprada muito } \\
\text { pequena (...) ou se } \\
\text { não tem condições } \\
\text { mesmo }\end{array}$ & $\begin{array}{c}\text { Raciocínio Moral } \\
\text { Deontológico / Respeito } \\
\text { à Vida }\end{array}$ \\
\hline $\mathrm{C} 8^{*}$ & & \multirow{3}{*}{$\begin{array}{l}\text { poderia levar em conta [o aborto } \\
\text { deveria ser permitido] }\end{array}$} & & $\begin{array}{l}\text { em alguns casos } \\
\text { (...) se for } \\
\text { estuprada...e } \\
\text { também se for } \\
\text { estuprada muito } \\
\text { pequena }\end{array}$ & $\begin{array}{l}\text { às vezes foi estuprada } \\
\text { e quer ter o filho }\end{array}$ & $\begin{array}{l}\text { Moral Intuitiva / Casos } \\
\text { Extremos e Exceções }\end{array}$ \\
\hline $\mathrm{C} 10^{*}$ & $\begin{array}{l}\text { a criança vai morrer de } \\
\text { fome }\end{array}$ & & aí...melhor nem ter né... & \multirow{2}{*}{$\begin{array}{l}\text { ou se não tem } \\
\text { condições mesmo } \\
\text { / se não tem } \\
\text { condições pra } \\
\text { criar }\end{array}$} & & $\begin{array}{c}\text { Raciocínio Moral } \\
\text { Consequencialista / } \\
\text { Ambição e Segurança } \\
\text { Financeira }\end{array}$ \\
\hline M9 & & & & & & $\begin{array}{l}\text { Moral Intuitiva / Ambição } \\
\text { e Segurança Financeira }\end{array}$ \\
\hline $\begin{array}{c}\text { M27, } \\
\mathrm{Ce} 28, \mathrm{G} 41\end{array}$ & & \multirow{2}{*}{$\begin{array}{l}\text { o aborto deve ser permitido / deve } \\
\text { poder fazer / poderiam pensar no caso } \\
\text { de fazer ou não o aborto }\end{array}$} & & \multirow{2}{*}{$\begin{array}{l}\text { dependendo do } \\
\text { caso / quando há } \\
\text { o estupro / } \\
\text { quando houver } \\
\text { estupro / se for } \\
\text { estuprada }\end{array}$} & & Moral Intuitiva \\
\hline M109 & $\begin{array}{l}\text { a pessoa não teve } \\
\text { culpa desse ato que foi } \\
\text { feito nela }\end{array}$ & & $\begin{array}{l}\text { ninguém é obrigado a assumir } \\
\text { riscos oriundos de um } \\
\text { acontecimento sobre o qual não } \\
\text { se tem controle }\end{array}$ & & & $\begin{array}{l}\text { Raciocínio Moral } \\
\text { Deontológico / Acidentes } \\
\text { e Não-Responsabilidade }\end{array}$ \\
\hline
\end{tabular}




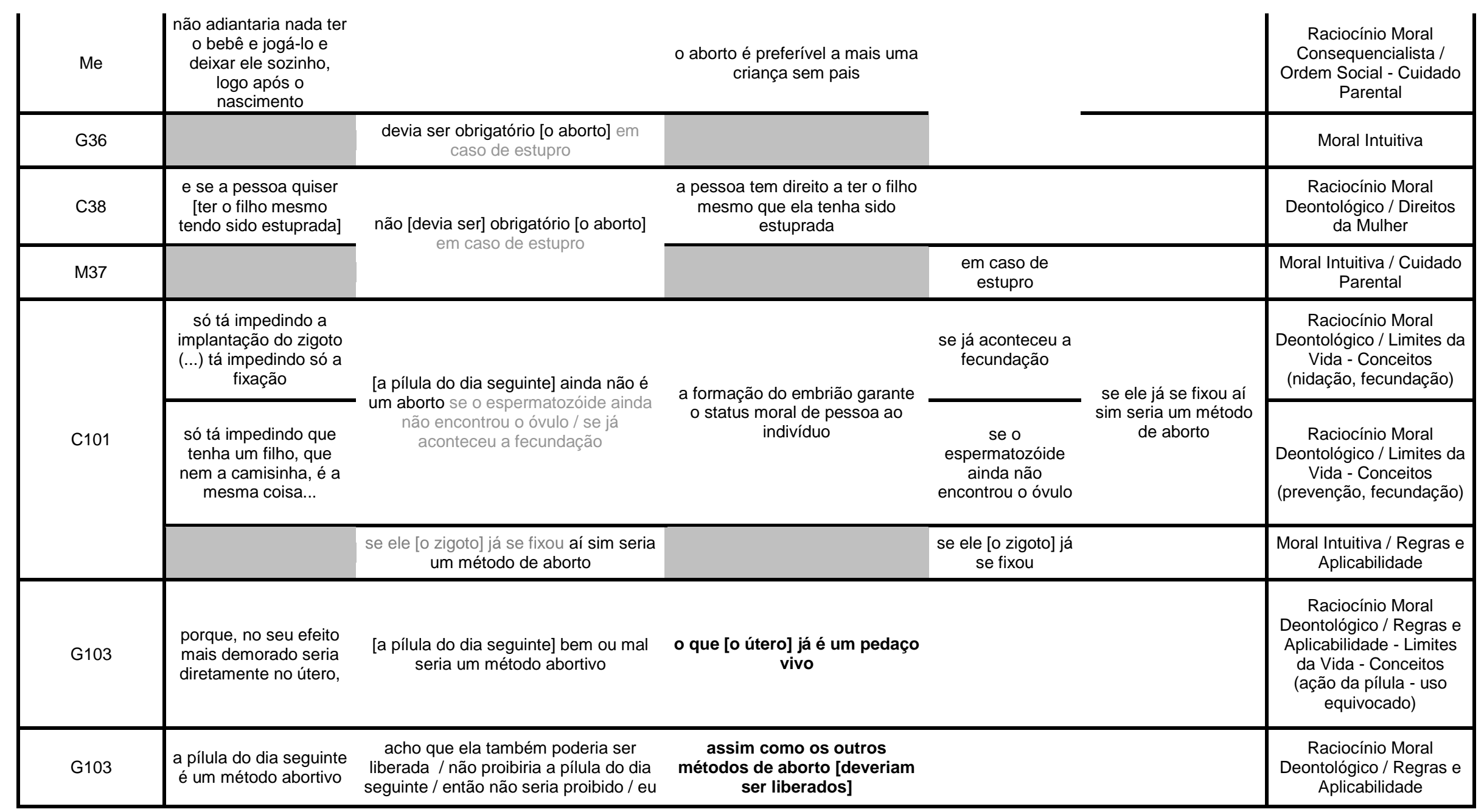




\begin{tabular}{|c|c|c|c|}
\hline \multirow[b]{2}{*}{$\begin{array}{l}\text { M99 [confusãa } \\
\text { com a pílua } \\
\text { anticoncepcional] }\end{array}$} & $\begin{array}{l}\text { ela é um método de } \\
\text { ajudar a menina a não } \\
\text { ficar grávida }\end{array}$ & $\begin{array}{l}\text { não é um aborto (...) eles } \\
\text { poderiam ter o ato e não estar } \\
\text { matando o bebê...não tá sendo } \\
\text { a criação de um bebê ainda... }\end{array}$ & $\begin{array}{l}\text { Raciocínio Moral } \\
\text { Deontológico / Regras e } \\
\text { Aplicabilidade - Limites } \\
\text { da Vida - Conceitos } \\
\text { (ação da pílula - uso } \\
\text { equivocado) }\end{array}$ \\
\hline & $\begin{array}{c}\text { ela pode tomar } \\
\text { diariamente antes da } \\
\text { gravidez ou quando ela } \\
\text { quisesse, se pra ela ou } \\
\text { pro parceiro dela a } \\
\text { camisinha não for um } \\
\text { método que pra eles... } \\
\text { eles não gostem na } \\
\text { hora de fazer o ato } \\
\text { sexual... } \\
\end{array}$ & é uma boa ajuda pra eles & $\begin{array}{l}\text { Raciocínio Moral } \\
\text { Deontológico / Limites da } \\
\text { Vida - Regras e } \\
\text { Aplicabilidade- } \\
\text { Conceitos (ação da pílula } \\
\text { - uso equivocado) }\end{array}$ \\
\hline C101 & $\begin{array}{l}\text { pra impedir que } \\
\text { acontecesse gravidez } \\
\text { indesejada... }\end{array}$ & $\begin{array}{l}\text { não acho [a pílula do dia } \\
\text { seguinte] um método de } \\
\text { aborto }\end{array}$ & $\begin{array}{l}\text { Raciocínio Moral } \\
\text { Consequencialista- } \\
\text { Planejamento Familiar }\end{array}$ \\
\hline
\end{tabular}

